TATJANA VONTA

\title{
ORGANIZIRANA \\ PREDŠOLSKA VZGOJA \\ V IZZIVIH DRUŽBENIH \\ SPREMEMB
}

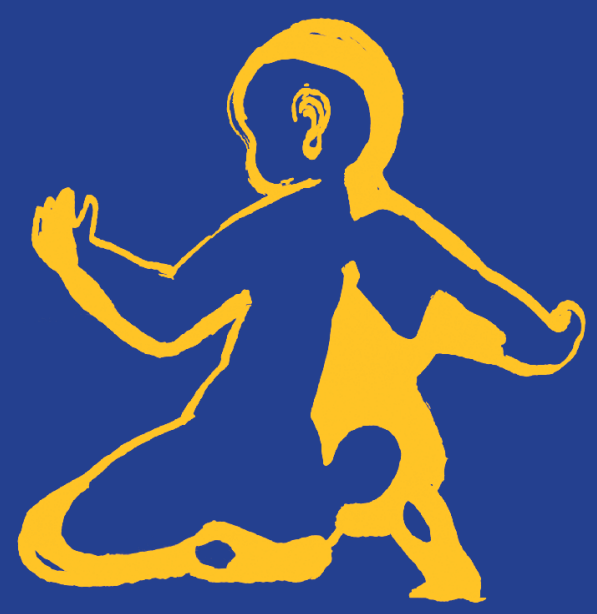

DIGITALNA KNJIŽNICA / DISSERTATIONES / 8

PEDAGOŠKI INŠTITUT / 2009 

O R G A N I Z I R A N A PREDŠOLSKA VZGOJA 
- $\theta 0$ 


\section{ORGANIZIRANA PREDŠOLSKA VZGOJA V IZZIVIH DRUŽBENIH SPREMEMB}


(1)

Tatjana Vonta

Organizirana predšolska vzgoja v izzivih družbenih sprememb

znanstvena monografija

Digitalna knjižnica

Uredniški odbor: Igor Ž. Žagar (Educational Research Institute \& University of Primorska), Jonatan Vinkler (University of Primorska), Janja Žmavc (Educational Research Institute),

Alenka Gril (Educational Research Institute)

Zbirka: Dissertationes (znanstvene monografije), 8

Glavni in odgovorni urednik: Igor Ž. Žagar

Urednik izdaje: Jonatan Vinkler

Recenzentki: Jurka Lepičnik Vodopivec, Tatjana Devjak

Oblikovanje, prelom in digitalizacija: Jonatan Vinkler

Lektorica: Almira Gregorič Kolenc

Založnik: Pedagoški inštitut

Gerbičeva 62, Sl-100o Ljubljana

Ljubljana 2009

Za založnika: Mojca Štraus

ISBN 978-961-270-026-3 (pdf)

http://www.pei.si/ISBN/978-961-270-026-3.pdf

ISBN 978-961-270-026-3 (html)

http://www.pei.si/ISBN/978-961-270-026-3/index.html

DOl: https://www.doi.org/10.32320/978-961-270-026-3

(C) 2009 Pedagoški inštitut/Educational Research Institute

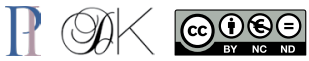

CIP - Kataložni zapis o publikaciji

Narodna in univerzitetna knjižnica, Ljubljana

$373.2(0.034 .2)$

$37.01(0.034 .2)$

VONTA, Tatjana

Organizirana predšolska vzgoja v izzivih družbenih sprememb [Elektronski vir] / Tatjana Vonta. - El. knjiga. - Ljubljana : Pedagoški inštitut, 2009. - (Digitalna knjižnica. Dissertationes ; 8)

Način dostopa (URL): https://www.pei.si/ISBN/organizirana-predsolska-vzgoja-v-izzivih-druzbenih-sprememb/

ISBN 978-961-270-026-3

249058048 
Seznam preglednic

Seznam slik

I Razvoj pedagoških idej in modelov na področju predšolske vzgoje od njenih začetkov do konca dvajsetega stoletja

Uvod

Predznanstveno, intuitivno humanistično obdobje

Prve institucije, namenjene predšlskih otrokom

Obdobje prvih znanstvenih zasnov organizirane predšolske vzgoje ali obdobje prebujanja

John Dewey in ideje progresivne pedagogike

Maria Montessori

Drugi modeli iz začetka 20. stoletja 28

Sovjetska pedagogika

Obdobje socialnega nemira in poudarjenih vplivov okolja ali obdobje dozorevanja

Čas po drugi svetovni vojni $3 \mathbf{I}$

Družbena dogajanja v šestdesetih in sedemdesetib letih

Znanstvene usmeritve 32

ERIK ERIKSON

JEAn Piaget 
Kaj se je dogajalo pri nas

\section{Predšolska vzgoja v izzivih družbe konec 20. in v začetku}

21. stoletja

Spremembe v družbi in njihov vpliv na vzgojo in izobraževanje

Od industrijskega modela izobraževanja k modelu ustvarjalne

delavnice oziroma ateljeju

Globalizacija in medkulturni dialog

Pripravljenost na spremembe

Človekove pravice in otrokove pravice kot osnova pristopov v vzgoji

in izobraževanju

Demokratizacija družbe in njen vpliv na vzgojo in izobraževanje 52

Spremembe znanstvenih paradigem

Predšolska vzgoja v izzivih sodobne družbe - obdobje zrelosti ali obdobje utrditve

Novi cilji

Otrokove pravice in potrebe ter zagovornistvo 59

Vpliv sodobnih studij o delovanju možganov 66

Otrokov razvoj in učenje 76

POVZETEK SPOZNANJ O OTROKOVEM RAZVOJU IN UČENJU 80

Skriti kurikulum, osredotočenost na otroka in razvojno primerna praksa 82

Partnerstvo z družinami

Odzivi prakse

Sodobno razumevanje kakovosti v organizirani predšolski vzgoji 99

Kakovost predšolske vagoje I03

Kakovost vrtca $z$ vidika otrok I08

KAKŠEN JE VPLIV KAKOVOSTI ORGANIZIRANE PREDŠOLSKE VZGOJE NA OTROKOV RAZVOJ I09

ŠTUDIJE O UČINKIH HEAD START PROGR AMOV IIO

Kakovost organizirane predšolske vzgoje z vidika staršev 123

Kakovost organiziranepredšolske vzgojez vidika širše skupnosti I25

Človeški potenciali I27

Človekove pravice I 27 
Participacija I 27

Zmanjševanje revščine I 28

Kakovost z vidika izvajalcev 136

Kako ocenjujemo kakovost v organizirani predšolski vzgoji $\quad$ I38

KAZALCI KAKOVOSTI ORGANIZIRANE PREDŠOLSKE VZGOJE I4O Kakovost vzgojiteljev $\quad \mathbf{I 4 3}$

SPREMEMBA KULTURE UČENJA IN SKRBI ZA OTROKE

Odločanje I44

Olajševanje in spodbujanje učenja I45

Modeliranje 146 EVALVACIJA VZGOJITELJA

Zakaj evalvirati vzgojitelja I5I

Osnove za oblikovanje evalvacije vzgojitelja I52

Značilnosti sistema evalvacije vzgojitelja I 54

Kriteriji evalvacije I 56

Viri informacij za evalvacijo vzgojitelja I 57

a) Opazovanje v oddelku I 58

b) Strukturirana refleksija I59

c) Dokumenti naćrtovanja (vzgojiteljeva priprava) I59

d) Razgovoripo opazovanju I60

e) Strokovniportfolio I6I

f) Drugidokazi I62

Evalvacijski postopki I64

Oblikovanje procesa I64

Kako sistem evalvacije vzgojiteljev vgraditi v sistem napredka, razvoja vrtca v smeri zviševanja kakovosti I65

Značilnosti profesionalnega razvoja I66

REFLEKSIJA SVOJE PRAKSE I68

SAMOOCENJEVANJE IN SAMOUSPOSABLJANJE I69

SKUPNOST UČEČIH I7 I 
VPLIV EVALVACIJE VZGOJITELJA NA NJEGOV PROFESIONALNI RAZVOJ

Združevanje zagotavljanja kakovosti in profesionalnega razvoja vzgojitelja I72

DIFERENCIACIJA I72

In kaj nas čaka v prihodnosti I75

Demografska gibanja I75

Spremembe v družini I78

Vrednote I79

Klimatske spremembe I79

Globalna ekonomija I80

Svet dela in poklicev I80

Investicije v izobraževanje I8I

Informacijsko-komunikacijska tebnologija I 8 I

Politicna participacija I82

Privatizacija I82

Družba blaginje in družba revščine I82

Slovar ključnih pojmov I85

Povzetek I89

Summary I93

Viri in literatura 197

Imensko kazalo 


\section{preglednic}

Preglednica 1: Stopnje psihosocialnega razvoja po Eriksonu $\quad 36$

Preglednica 2: Pogled na zgodnje otroštvo z vidika pravic in potreb $5 \mathrm{I}$

Preglednica 3: V raziskavah dokazani vplivi višje kakovosti organizirane predšolske vzgoje na razvoj otrok

Preglednica 4: Koristi organizirane predšolske vzgoje za otroke, odrasle in družbo v celoti I32

Preglednica 5: Cilji v procesu spreminjanja vrtca I38

Preglednica 6: Združevanje zagotavljanja kakovosti in profesionalnega razvoja $v$ procesu evalvacije vzgojitelja 

Slika 1: Gostota povezav med nevroni v različni starosti $\quad 69$

Slika 2: Občutljiva obdobja za zgodnji razvoj 70

Slika 3: Razvoj človeških možganov z ozirom na formiranje sinaps za različne funkcije 7 I

Slika 4: Povezanost organizirane predšolske vzgoje z razvojem človeštva

Slika 5: Rast možganov in javne investicije, namenjene otrokom $\quad$ I35 Slika 6: Heckmanova krivulja: Prej ko začnemo z vlaganjem v človeške vire, višji je povratek 

I RAZVOJ PEDAGOŠKIH IDEJ IN MODELOV NA PODROČJU PREDŠOLSKE VZGOJE OD NJENIH ZAČETKOV

DO KONCA DVAJSETEGA STOLETJA 

ako kot za večino področij človekove dejavnosti lahko tudi za po1 dročje predšolske vzgoje iščemo začetke daleč nazaj v zgodovini človeštva. Čeprav je predšolska pedagogika kot znanstvena disciplina razmeroma mlada, sta področju predšolske vzgoje svojo pozornost namenila že filozofa antične Grčije Platon (427-347 pr. n. št.) in Aristotel (394-322 pr. n. št.), ki sta zagovarjala idejo, da se vzgoja otroka začne veliko pred šestim letom starosti. Oba sta opozarjala na individualne razlike v osebnosti otrok ter učenju. Tudi Jan Amos Komenský (1592-1670) je v svojem delu Informatorium školy mateřské zagovarjal isto idejo in poudarjal pomen prvih let življenja otroka v okrilju materinega naročja ter vzgojo enačil z igro, življenjem in rastjo kot tako.

Čeprav so vsi našteti filozofi in pedagogi poudarjali pomen predšolske vzgoje ali vzgoje, ki se začenja ob rojstvu otroka in traja do njegove vključitve v šolo, so pri tem razmišljali predvsem o tem, da se vzgojno-izobraževalni proces ne začenja šele s šolanjem, ampak veliko prej - ob vzgoji otroka v njegovem domu, torej pred začetkom vzgojno-izobraževalnega procesa, ki ga je namenoma izvajal posameznik na otrokovem ali na svojem domu, ali pa ga je izvajala institucija izven doma nekako okrog šestega ali sedmega leta otrokove starosti. O organizirani predšolski vzgoji lahko govorimo šele veliko kasneje.

V obdobju pred ustanovitvijo prvih institucij za predšolske otroke so se že začele oblikovati zasnove gledanja na eno od osrednjih vprašanj, okrog katerega so se kasneje razvila različna gledanja na predšolskega otroka, ki so kasneje vplivala na razvoj različnih teorij o otrokovem razvoju, s tem pa 
tudi na razvoj organizirane predšolske vzgoje. Gre za filozofska vprašanja o tem, kakšna je narava otroka, zakaj je otrok takšen kot je, ali na to, kakšen je, bolj vpliva njegova narava in faktorji dednosti ali okolje. Možni odgovori se razvrščajo na eno ali drugo stran ali pa so nekje vmes med dednostjo in okoljem. Na tako zastavljenem vprašanju se razrešuje osnovno protislovje, na katerega doslej še nismo dobili dokončnega odgovora, čeprav ga sodobne študije o delovanju in razvoju možganov vse bolj pojasnjujejo, in okrog katerega se vrti zgodovina predšolske pedagogike in organizirane predšolske vzgoje. Kako interpretiramo otrokovo naravo, močno vpliva na to, kako mislimo o otroku in kakšen odnos oblikujemo z njim, kakšne cilje si postavimo, kako razumemo vlogo odraslega in otroka v medsebojni komunikaciji, skratka na vse bistvene točke, ki opredeljujejo organizirano predšolsko vzgojo.

Cerkev je, kot najvišja avtoriteta v družbi pred renesanso, postavila svojo lastno teorijo, da je otrok po naravi slab, saj je bil rojen v izvirnem grehu in mu lahko samo disciplina pomaga pri tem, da ne postane še bolj pregrešen. Čeprav je malo strokovnjakov, ki se še nagibajo k tej ideji v današnjem času, pa ostanki takšne filozofije še živijo. Še vedno obstajajo tendence $h$ »klestenju«, obvladovanju, uklanjanju, profiliranju, gnetenju in šabloniziranju otrokove narave.

Konec 17. stoletja je angleški filozof John Locke (1632 - 1704) podal osnovo drugačne usmeritve gledanja na otrokovo naravo, ko je postavil tezo, da se otrok rodi kot »tabula rasa «. Prepričan je bil, da otrok nima nobenih dednih zasnov, ki bi vplivale na njegov razvoj in da lahko le okolje določa njegov razvoj. Otrok je po njegovem mnenju pasivno in receptivno bitje, ki se uči tako, da vase sprejema dražljaje od drugih in iz okolja. Locke je tako postavil temelje kasnejših behaviorističnih pristopov k vzgoji in izobraževanju, ki so se razvili v sredini 20. stoletja in so še danes močno prisotni na našem področju.

V začetku 18. stoletja pa se je začela razvijati še tretja smer gledanja na otrokovo naravo. Francoski filozof Jean Jacques Rousseau (1712 - 1778) je menil, da se otrok rodi s prirojeno težnjo k dobremu, ki pa jo odrasli lahko pokvarijo. Tako pojmovanje je seveda prineslo veliko razliko v pojmovanju otroka. Rousseau se je zavzemal za otrokov naravni razvoj z minimalnim vmešavanjem odraslih. Verjel je, da narava skrbi za razvoj in da tak razvoj poteka kot »odpiranje popka pri vrtnici«, kjer cvetnih listov ne odpiraš, saj se sami razcvetijo. Otrok se po njegovem mnenju razvija po naravni logični poti v skladu z nekim notranjim načrtom oziroma podedovanimi zasnovami. Tak pogled na otrokovo naravo je kasneje usmerjal nativistič- 
ne pristope, ki so se razvili v začetku 20. stoletja. Vsekakor pa je Rousseau močno zaznamoval tudi 18 . stoletje z bolj humanim odnosom do otroka, ki se je kasneje v 19. stoletju kazal tudi v skrbi posameznikov za razvoj, učenje, zdravje in zaščito otrok.

O razvoju organizirane predšolske vzgoje pa lahko govorimo šele kasneje, v obdobju prehoda iz obrtniško manufakturne v industrijsko družbo. Tako njeni začetki segajo $\mathrm{v}$ predznanstveno, intuitivno humanistično obdobje. Za znanstveno zasnovano obdobje razvoja organizirane predšolske vzgoje, ki se je začelo konec 19. stoletja, so značilne tri odločujoče faze razvoja, ki so prinesle izjemne spremembe na področje razvoja organizirane predšolske vzgoje. Prvo sega v obdobje »progresivne pedagogike «, drugo v obdobje šestdesetih let dvajsetega stoletja, tretje sega v obdobje na koncu prejšnjega stoletja in na začetku tega stoletja. Osnovna gibala, ki so vplivala na nastanek in spreminjanje organizirane predšolske vzgoje, lahko pripišemo naslednjim faktorjem:

- razvoju in spremembam v družbi, ki so pogojevali spreminjanje ciljev in poslanstva te dejavnosti ;

- razvoju znanosti in širjenju znanstvenih disciplin, ki proučujejo otroka ter področje vzgoje in izobraževanja;

- razvoju idej o posebni skrbi in zaščiti otrok ter njihovim potrebam in pravicam;

- razvoju in raznolikosti gledanja na otrokovo naravo, razvoj in učenje.

Ker je skorajda nemogoče ločiti posamezne faktorje, bomo v nadaljevanju pozornost namenili kratkemu zgodovinskemu pregledu razvoja organizirane predšolske vzgoje in znotraj posameznih obdobij razvoja pozornost usmerili na poglavitna gibala tega razvoja. Pri tem bomo pozornost namenili družbenim dogajanjem in tudi kratki osvetlitvi najbolj pomembnih teorij, ki so zaznamovale razvoj področja. V zgodovinskem pregledu organizirane predšolske vzgoje se bomo omejili predvsem na razvoj te dejavnosti, ki ima svoje korenine v Evropi in Ameriki, saj na žalost ni veliko virov o razvoju te dejavnosti v drugih kulturah. Pri oblikovanju zgodovinskega pregleda smo si pomagali z različnimi viri. ${ }^{1}$

\footnotetext{
${ }^{1}$ Bernard Spodek, Handbook of research on the Education of Young Children, New York 1993; Mary Renck Jalongo, Joan Packer Isenberg, Exploring Your Role, A Practitioner's Introduction to Early Childhood Education, Merrill 2000; Robert Murray Thomas, Comparing Theories of Child Development, Belmont 1992; Nina Bagratovna Mčedlidze, Aleksandra Andrejevna Lebedenko, Jelizaveta Anatoljevna Grebenščikova, Istorija doškolnij zarubežnoj pedagogiki, Moskva 1984; Carol Seefeldt, Nita H. Barbour, Early Childhood Education - an introduction, Merrill 1994; Carol Garhart Mooney, Theories of Childhood, Minnesota 2000.
} 



\section{Predznanstveno, intuitivno human- istično obdobje}

\section{T}

ako kot vsa področja človekove dejavnosti se je tudi organizirana . predšlska vzgoja razvijala v odvisnosti od razvoja in sprememb v družbi. Nastanek organizirane predšolske vzgoje povezujemo z obdobjem prehoda iz manufakturnega $\mathrm{k}$ industrijskemu načinu proizvodnje. Za manufakturno proizvodnjo je bilo značilno, da so dečki pridobili svoj poklic v glavnem v krogu svoje družine in nadaljevali tradicijo obrtniške proizvodnje v glavnem doma. Deklice pa so svoje poklicne interese v večini primerov zaključile kot matere in gospodinje in tudi tega »poklica« so se lahko naučile v krogu družine.

Za razvijajočo industrializacijo pa je bilo značilno, da je potrebovala več delovne sile, ki se je zbirala okrog industrijskih središč in je tako potrebovala več izobrazbe. Industrializacija in urbanizacija sta povzročili migracijo ljudi iz podeželja v industrijska središča, kjer so bile razmere za njihovo življenje spremenjene. Te spremembe pa so vplivale tudi na strukturo in način življenja v družinah. Družine so postajale manjše, pogosto so se v delovni proces vključili tudi ženska in otroci od zgodnjih let življenja dalje. Zgodovinsko se s tovrstno problematiko srečamo že pred začetkom francoske revolucije.

Razvoj industrijske družbe je izzval potrebo po drugače izobraženih ljudeh, ki so se sposobni prilagoditi potrebam novega tovarniškega načina proizvodnje $\mathrm{v}$ tovarnah. Izzval pa je tudi intuitivno humanistične nagibe posameznikov $\mathrm{k}$ skrbi za otroke, ki so ostajali doma sami zaradi celodnevne odsotnosti staršev, hkrati pa so jih želeli obvarovati pred prezgodnjim vključevanjem v proizvodni proces. Poleg tega pa lahko tudi ugoto- 
vimo, da v tem obdobju še ni bilo razvitih znanstvenih osnov, ki bi usmerjale odločitve pedagogov o tem, kako oblikovati organizirano predšolsko vzgojo. Govorimo o predznanstvenem obdobju razvoja organizirane predšolske vzgoje, ki je temeljil na intuitivnih odločitvah posameznikov o tem, kaj je za otrokov razvoj dobro in kako se predšolski otrok razvija. Zato smo to obdobje razvoja organizirane predšolske vzgoje poimenovali intuitivno humanistično obdobje.

\section{Prve institucije, namenjene predšolskim otrokom}

$S$ prvo institucijo, ki je bila namenjena prav predšolskim otrokom, se srečamo v takratni Franciji pod imenom »pletilna šola «, ki jo je ustanovil Friederick Oberlin leta 1769. V odvisnosti od letnega časa so se predšolski otroci v »pletilni šoli« zbirali enkrat ali dvakrat tedensko po eno do štiri ure. Že ime tako organizirane predšolske vzgoje pa nam pove, da je bilo težišče dejavnosti usmerjeno na pridobivanje tistih spretnosti in znanj, ki naj bi jih otroci potrebovali v takratni prevladujoči manufakturni proizvodnji, ta pa so bila obogatena še z znanji o naravi in religiji. Da bi »učiteljice za male otroke «, kot jih je poimenoval Oberlin, ${ }^{1}$ dosegle cilje, ki jih je njegova »pletilna šola« skušala doseči, je sam usposabljal kmečka dekleta za to dejavnost. Način dela je temeljil na podajanju navodil ob slikah, spoznavanju ob neposrednem opazovanju (ki je bilo vezano na prepoznavanje strupenih in nestrupenih rastlin, ki so jih otroci lahko videli v svojem okolju), ponavljanju in pomnjenju zgodb iz biblije ter religioznih pesmi. Prav izraziti religiozni usmerjenosti Oberlinove organizirane predšolske vzgoje ter hkratnemu prehajanju v industrijsko družbo in širjenju idej francoske revolucije v tem obdobju lahko pripišemo dejstvo, da so bile njegove ideje časovno in prostorsko omejene in kmalu presežene.

Leta 1816 je na Škotskem Robert Owen za otroke svojih delavcev ustanovil »Novi inštitut za formiranje karakterja«, ki je bil razdeljen na tri stopnje in med katerimi je bila prva, imenovana $\gg$ infant school «, namenjena otrokom od tretjega do šestega leta starosti. ${ }^{2} \mathrm{Z}$ vključevanjem otrok v šolo do desetega leta starosti je Owen zaščitil otroke pred vključevanjem v delo in je tako za tiste čase močno posegel na področje varovanja otrokovih pravic in tudi na področje zviševanja kakovosti njihovega življenja. V njegovih predšolskih institucijah so bili otroci deležni igre in razvedrila predvsem na prostem, da bi si okrepili zdravstveno stanje. Tu se prvič srečuje-

${ }^{1}$ Citirano po Nina Bagratovna Mčedlidze, Aleksandra Andrejevna Lebedenko, Jelizaveta Anatoljevna Grebenščikova, Istorija doškolnij zarubežnojpedagogiki, Moskva 1984.

${ }^{2}$ N. B. Mčedlidze, A. A. Lebedenko, J. A. Grebenščikova, n. d. 
mo $z$ varstveno, vzgojno in izobraževalno funkcijo organizirane predšolske vzgoje, saj naj bi z vključevanjem otrok v te institucije zagotavljali skrb za njihovo varnost, nego in zdravje $\mathrm{v}$ času odsotnosti njihovih staršev, hkrati $s$ tem pa poskrbeli tudi za to, da bi se otroci pripravili na »novo družbo«, ki si jo je zamislil Owen.

Kot najbolj odmeven model organizirane predšolske vzgoje v 19. stoletju pa zagotovo lahko opredelimo Fröblov vrtec. Friederich Fröbel je leta 1837 odprl institucijo, ki je bila namenjena tudi predšolskim otrokom, in jo poimenoval »Zavod za razvoj ustvarjalnega spodbujanja dejavnosti otrok in mladine «. Tri leta kasneje je organizacijo vzgoje za tiste otroke pod šestimi leti starosti poimenoval $\gg$ kindergarten $\ll$. Prav sprememba imena je verjetno povzročila, da različni avtorji navajajo različne letnice ustanovitve Fröblovega vrtca. ${ }^{3}$ Menil je, da so najzgodnejša leta najbolj kritična v človekovem življenju, saj se na tej osnovi gradi vse nadaljnje delovanje v življenju.

Fröblov vrtec je bil ustvarjen tako, da bi otrok lahko rasel naravno »kot cvetlica v vrtu«, ki bo vzcvetela v vsej svoji lepoti, če bo primerno negovana in oskrbovana. Menil je, da je spoznanje proces prebujanja dremajočih notranjih sil s senzornimi izkušnjami. Osnovo njegovega programa so tvorili igra, samoizražanje, razvijanje čutil ter harmonično življenje z drugimi. Oblikoval je vzgojna sredstva in dejavnosti, ki si skrbno sledijo v zaporedju $s$ podrobnimi navodili za izvajanje. Njegov program je bil razdeljen na dva dela, imenovana $\gg$ darila $\ll$ in $\gg$ zaposlitve $\ll$. V prvem delu so otroci dobili razne igrače za igro, $v$ drugem delu pa so dobili naloge, ki naj bi pomagale razvijati tiste sposobnosti, ki jih bodo potrebovali v prihodnje (gubanje, striženje, modeliranje, luknjanje papirja ipd.). To delitev so vrtci ohranjali še več kot sto let, ponekod jih tudi še danes, ko življenje otrok v vrtcu delijo v t. i. dejavnosti po želji otrok in dejavnosti, ki jih usmerja vzgojiteljica. Petje, ples ter igra v Fröblovem vrtcu pa naj bi otroke zbližali z Bogom. Ne glede na vse kritike, ki jih je doživel njegov vrtec, je potrebno poudariti, da je v organizirano predšolsko vzgojo prinesel igro.

Če skušamo povzeti značilnosti organizirane predšolske vzgoje v njenem najzgodnejšem obdobju razvoja, lahko ugotovimo, da so na njen razvoj poleg splošnih družbenih dejavnikov, kot so razvitost družbe, postopne spremembe $\mathrm{v}$ načinih proizvodnje, migracijski procesi, zaposlovanje žensk izven družine, ipd., vplivale tudi filozofske misli mislecev dotedanjega časa, ki so opozarjale, da se vzgoja in izobraževanje ne začneta z vstopom v šolo, ampak od otrokovega rojstva naprej v družini. Kot eno od po-

${ }^{3}$ B. Spodek, Handbook of research on the Education of Young Children, New York 1993; Milica Bergant, Teme iz pedagoške sociologije, Ljubljana 1970. 
membnih gibal njenega razvoja pa je bilo tudi vse bolj prisotno spoznanje, da je majhen otrok drugačen od svojih vrstnikov. Pri začetnikih institucionalne organizirane predšolske vzgoje (Owen, Fröbel), ki so organizirali institucionalno predšolsko vzgojo konec 18 . in v 19. stoletju, so imela ta spoznanja povsem intuitivno in humanistično naravo. 


\section{Obdobje prvih \\ znanstvenih zasnov \\ organizirane pred- \\ šolske vzgoje ali \\ obdobje prebujanja}

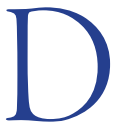

rugi vzpon doživi organizirana predšolska vzgoja konec 19. stoletja in v začetku 20. stoletja, ko nastanejo prve znanstvene podlage za organiziranje institucionalne predšolske vzgoje v gibanju za študij otroka. Znanstveno osnovo k študiju otroka je podal Charles Darwin (18091882) z zapiski o svojih otrocih, kasneje pa se je razvilo v t. i. »gibanje za študij otroka«. Gibanje je bilo zasnovano okrog Stanleya Halla (18441924) in kasneje Arnolda Gesella (1890-1961). Oba sta z iskanjem norm ali povprečnih nivojev razvoja otrok (zbranih na skupinah otrok) v različni starosti, oblikovala zasnovo za znanstveni študij otroka. Gibanje je prineslo znanstveni nivo spoznanj o otrokovem razvoju in učenju, pa tudi vse več spoznanj o tem, kako se otrok razvija in uči in končno nativistično teorijo razvoja, ki sloni na principu zorenja.

Nativisti trdijo, da se otroci razvijajo v določenem zaporedju in gredo skozi iste stopnje razvoja kot rezultat zakonov zorenja. Gesell je sicer priznaval, da ima okolje pri tem določeno vlogo, vendar je poudarjal, da je osnova za razvoj podedovana in se s pomočjo zorenja odvija nepretrgoma in spiralasto. Lastna podedovana razvojna ura, ki jo imajo otroci v sebi, pa določa, kdaj bo otrok dosegel določeno stopnjo razvoja; vsako prehitevanje je po mnenju nativistov nemogoče in škodljivo.

Takšno gledanje na razvoj in učenje otrok je seveda potisnilo pedagoga v funkcijo tistega, ki sledi otrokovemu razvoju in mu nudi pomoč le, če jo otrok potrebuje. Tak pogled na otrokovo naravo je usmerjal tudi nekatere pedagoške pristope svobodne vzgoje, ki si ni delala skrbi s cilji, strokovno odgovornostjo, produktivnostjo, učinkovitostjo ipd. Razmeroma hitro 
je imelo gibanje svoj vpliv tudi na pedagoškem polju organizirane predšolske vzgoje, ki naj bi bila skladna z nivojem razvoja otrok. Tako naj bi izobraževanje sledilo razvoju tako, da bi otrokove zmožnosti ocenili, na osnovi te ocene pa naj bi bil vzgojitelj zmožen določiti, česa je otroka mogoče naučiti, in omogočal takšne izkušnje, ki bi ustrezale razvijajočim se zmožnostim otroka.

\section{John Dewey in ideje progresivne pedagogike}

Vzporedno s temi dogajanji na področju študija otroka je nastajalo tudi gibanje »progresivne pedagogike«, ki se je oblikovalo okrog Johna Deweya (1858-1952). Med drugim je zagovarjal izkustveno učenje ter tezo, da naj bi bili vzgojno-izobraževalni programi zgrajeni na interesih otrok. Deweyevo pisanje in njegovo gibanje sta postali vse širše sprejeti in podprti. Dewey je sam ustanovil svojo šolo (laboratorij na univerzi v Chicagu) in v njej proučeval kurikulum. Prepričan je bil, da je potrebno kurikulum osredotočiti na otroka in vključiti takšne vsebine, ki bodo otrokom omogočale razumevanje socialnih namenov in skupnosti. Bil je zagovornik aktivnega učenja, materialov, ki jih lahko uporabljamo na različne načine ter principa od bližnjega in znanega $\mathrm{k}$ daljnemu in neznanemu. Ključna misel njegove filozofije je bila, da je potrebno otroke pripravljati na to, da bodo postali državljani demokratičnih družb. Ta cilj pa lahko po njegovem mnenju dosežemo le, če jim damo možnost misliti, sklepati, sprejemati odločitve danes, tukaj in sedaj. Tako je cilje iz prihodnosti prenesel v sedanje življenje. Po njegovem mnenju so namreč izkušnje iz neposrednega življenja najboljši način učenja in zato naj bi na njih temeljil program organizirane predšolske vzgoje.

Zagovarjal je misel, da se otroci učijo spretnosti, ki jih potrebujejo za mišljenje ob igri in dejavnostih ter v interakciji z okoljem. Zato je poudarjal pomen konkretnih in za otroka osebno pomembnih in smiselnih izkušenj. Socialno življenje v skupnosti pa je pojmoval kot osnovo otrokovega izobraževanja in vzgoje. Otrok ima v pogojih organizirane vzgoje in izobraževanja možnost pridobiti izkušnje o skupnosti, ki jih v igri in drugih oblikah izražanja preoblikuje in tako oblikuje pomen oziroma smisel iz teh izkušenj.

Leta 1897 je Dewey izdal svojo filozofijo edukacije v dokumentu, ki ga je poimenoval $\gg$ Moj pedagoški credo $\ll^{1}$ in $\mathrm{v}$ njem je izpostavil naslednja prepričanja:

- da se otroci najbolje učijo v interakciji z drugimi ljudmi, ko delajo sami in v sodelovanju z vrstniki in odraslimi;

${ }^{1}$ C. G. Mooney, Theories of Childhood, Minnesota 2000. 
- da interesi otrok tvorijo osnovo načrtovanja kurikuluma;

- da so interesi in lastnosti vsakega posameznega otroka v skupini in skupine kot celote osnova za načrtovanje učnih izkušenj;

- da je izobraževanje del življenja in ne nekaj posebnega in naj bi bilo zato usmerjeno na to, kar oseba mora vedeti in znati sedaj - v tem trenutku življenja, ne pa, da ga pripravlja za prihodnost. Zato naj bi kurikulum rasel iz situacij doma, pri delu in iz drugih življenjskih situacij;

- da mora biti pedagog občutljiv za vrednote in potrebe družin. Vrednote in kultura družin ter skupnosti, v katerih živijo, bi se po njegovem mnenju morale zrcaliti v instituciji;

- da pedagogi otrok ne učijo le »predmetov«, ampak tudi tega, kako živeti v skupnosti. Prav tako meni, da pedagogi ne učijo le posamezne otroke, ampak oblikujejo skupnost;

- da morajo pedagogi zaupati v svoje zmožnosti in spretnosti, v svoje znanje in izkušnje in ob njihovi rabi omogočati primerne aktivnosti, ki gojijo možnosti za proučevanje in dispozicije za učenje pri otrocih;

- da naj bi pedagogi pomagali otrokom, da si le-ti ustvarjajo smisel življenja v svetu;

- da je za pedagoga pomembno, da opazuje otroka in na osnovi tega opazovanja določi, za kakšne vrste izkušenj se otrok zanima in je zanje pripravljen;

- da morajo pedagogi investirati v načrtovanje in organiziranje otrokovih učnih aktivnosti, kar pomeni, da morajo zasnovati kurikulum na osnovi poznavanja otrok in njihovih zmožnosti.

Ideje Deweya in ideje gibanja za študij otroka so močno vplivale na progresivno reformsko gibanje na področju organizirane predšolske vzgoje, ki je nastalo kot protiutež Fröblovemu modelu. Menili so, da so njegova »darila« za otroke preveč simbolična, abstraktna in nepovezana $z$ otrokovim življenjem, »zaposlitve« pa preveč utrudljive in preveč strukturirane. $\mathrm{V}$ vrtec so tako prišle različne dejavnosti, v katerih so otroci pridobili izkušnje iz »pravega« sveta in osebno pomembne izkušnje, iz katerih otrok lahko doseže razumevanje sveta. V vrtec pa so vnesli tudi dejavnosti, v katerih je otrok lahko raziskoval svoje neposredno okolje (umetnost, gradnja s kockami, dramatizacija, tradicionalne pesmi in igre, ki so jih otroci srečevali v svojem okolju) in spoznaval svet. ${ }^{2}$

${ }^{2}$ M. R. Jalongo, J. P. Isenberg, Exploring Your Role - A Practitioner's Introduction to Early Childhood Education, Merrill 2000. 
Za takšno izobraževanje pa je bilo potrebno imeti drugačnega pedagoga, ki ne bo le sledil napisanim navodilom, kako izvajati določeno dejavnost z otroki, kot je to določal Fröbel. Dewey ${ }^{3}$ se je zavzemal za pedagoga kot aktivnega raziskovalca, ki neprestano ocenjuje in diagnosticira učenje otrok in njihovo rast, da bi pripravil nove učne dejavnosti. Vzgojitelja pojmuje kot vodnika, ki nudi pomoč, spodbuja in opazuje otrokove izkušnje ter po potrebi daje nove usmeritve. S svojimi idejami je Dewey prinesel v organizirano predšolsko vzgojo odprtost, fleksibilnost, upoštevanje potreb ter raznolikosti otrok, ki prihajajo $\mathrm{v}$ vrtec iz različnih okolij in kultur ter potreb razvijajoče se demokracije.

Dela progresivistov in zagovornikov študija otroka so močno vplivala na pojavljanje različnih modelov organizirane predšolske vzgoje $\mathrm{v}$ tistem času, pa tudi danes. Progresivistom so med drugim očitali, da otrokom nudijo preveč svobode brez primernega vodenja oziroma usmerjanja, čeprav je Dewey sam opozarjal na nujnost in pomen selekcije in na organizacijo področij dejavnosti oziroma predmetov in da otrok potrebuje pedagoga, ki odloča, kaj je varno, pa tudi razvojno in individualno primerno. ${ }^{4}$ Zavedal pa se je tudi nevarnosti odmika od tradicionalnih pristopov poučevanja, če pedagog jasno ne razume novih usmeritev. Prepričan je bil, da kakovostno poučevanje temelji na dobrem poznavanju otrok, izhajanju iz preteklega, že naučenega in na dobrem načrtovanju izkušenj. Dewey ni enačil edukacije in izkušenj, čeprav sta obe kategoriji povezani. Menil je, da nekatere izkušnje niso edukativne. Tako zanj aktivnost, ki ni smiselna in organizirana, ni učna aktivnost. Mehanično recitiranje dejstev, ki so izven konteksta, pa tudi skrbno načrtovano učno okolje, v katerem pedagog prepušča otroke brez namigov, sugestij, pa tudi slučajno izbrane aktivnosti brez nadgradnje ali namena, je kritiziral. Pedagog naj bi se vedno spraševal o naslednjem:

- ali aktivnost širi tisto, kar otroci že vedo;

- kako mu bo aktivnost pomagala v razvoju;

- kakšne spretnosti bo razvil;

- ali bo aktivnost pomagala otroku bolje poznati svet okrog njega in bolj polno živeti v tem svetu.

Učna izkušnja naj bi po Deweju temeljila na opazovanju in spraševanju otrok o tem, kar že vedo. Na tej osnovi pedagog pripravi pogoje za to, da si pridobijo tiste izkušnje, ki jih še ne poznajo. Pri tem pedagog dokumentira, kako se otroci učijo. Uspeh učenja pa naj meri z ugotovitvijo, do kolikšne

${ }_{3}^{3}$ John Dewey, Democracy and education, New York 1916/85.

${ }^{4}$ John Dewey, citirano po: C. G. Mooney, Theories of Childhood, Minnesota 2000. 
stopnje je učenje vodilo k naslednjemu področju proučevanja. Drugi kazalec uspeha pa leži v ugotavljanju stopnje zaupanja otrok v svoje zmožnosti in v stopnji zadovoljevanja njihove vedoželjnosti v procesu učenja.

\section{Maria Montessori}

Skoraj istočasno je v Italiji nastajal še en model organizirane predšolske vzgoje, ki ga je zasnovala Maria Montessori (1870-1952) v svoji ustanovi »Casa dei Bambini«, ki je začela delovati leta 1907. Maria Montessori je bila prva ženska v Italiji, ki je v tistem času študirala in končala študij medicine kljub nasprotovanju njenega očeta, ki jo je silil v učiteljski poklic, v tistem času edini poklic, ki je zahteval več šolanja, v katerega so prihajale tudi ženske. Kot pediatrinja se je srečevala z otroki, še preden je odprla svoj vrtec. Ta je bil namenjen predšolskim otrokom iz revnega delavskega predela v Rimu. V svoj model dela s predšolskimi otroki je prenesla bogate izkušnje, ki jih je imela pri delu z bolnimi otroki in otroki s posebnimi potrebami, zlasti tiste izkušnje, ki se nanašajo na individualizacijo ter samoaktivnost.

Veliko pozornost je namenila pripravi okolja v vrtcu. To okolje ni pojmovala le v smislu fizičnega okolja z opremo in materiali, ampak so okolje zanjo predstavljali tudi odrasli in otroci, ki si delijo ta prostor. Po njenem mnenju se otroci učijo jezika in drugih pomembnih življenjskih veščin iz okolja, v katerem živijo in zato je pomembno, da je to okolje urejeno in lepo. Materiali in oprema naj bi bili otrokom dostopni in organizirani tako, da le-ti z lahkoto najdejo, kar iščejo. Otroci si na ta način oblikujejo samostojnost in odgovornost $\mathrm{v}$ odnosu do lastnega učenja.

Osnovna premisa njenega modela je bila v prepričanju, da se predšolski otroci učijo $s$ čutili oziroma iz senzornih izkušenj. Da bi vsa čutila lahko izkoristili, pa potrebujejo ustrezno orodje in opremo, ki naj bo usklajeno z velikostjo njihovih teles, rok, prstov in bo pri tem še delovalo. Ideja o opremi in materialih, ki bi ustrezali velikosti otrok, je bila za tiste čase revolucionarna in hkrati težko uresničljiva, saj tega ni bilo na trgu. Prav zato je Maria Montessori uresničevanju te ideje namenila toliko pozornosti. Vodila jo je pri oblikovanju opreme in pohištva v velikosti otrok (stoli, mize, omare), kar odseva idejo razvojno primernega okolja. Poleg pohištva pa je oblikovala tudi številna orodja, ki predstavljajo pomanjšano obliko orodij, katera sicer uporabljajo odrasli (metle, smetišnice, vrči, krožniki, škarje, orodje za obdelavo lesa, ipd).

Menila je, da imajo otroci radi strukturo in red, da naj bi se učili praktičnih stvari, branja, pisanja, računanja, razvijali pa naj bi tudi čutila ter koordinacije gibov. V ta namen je oblikovala številna posebna vzgojna sredstva, ki jih še danes srečujemo po vrtcih kot so: pretikanke, okviri z različnimi načini zave- 
zovanja in zapenjanja ipd. Veliko teh sredstev omogoča otroku samokontrolo in seveda možnost, da sproti ocenjujejo svoja dejanja in jih v primeru, če niso pravilno opravljena, popravijo tako, da na koncu nalogo opravijo pravilno.

Maria Montessori je zelo cenila otrokovo samostojnost in odgovornost. Po njenem mnenju se otroci najbolje učijo $s \gg$ počenjanjem « in ponavljanjem istih opravil. Prepričana je bila, da odrasli preveč časa namenjajo temu, da otrokom strežejo, oziroma počno stvari namesto njih. Pri tem je za odraslega seveda mnogokrat mnogo lažje postoriti nekaj namesto otroka, kot pa otroku nuditi možnosti, da to naredi sam. Menila je, da otroci želijo in čutijo potrebo skrbeti zase in za okolje okrog sebe in da se tega, kako naj to počno, lahko naučijo le, če to počno.

Pri svojem delu je izhajala iz idej Rousseauja, Pestalozzija, Fröbla in Seguina. Slednji je razvil sistem izobraževanja otrok s posebnimi potrebami. Čeprav je verjela v naraven razvoj otroka, je hkrati tudi zaupala v njegove zmožnosti vplivanja na lasten razvoj od znotraj, pa tudi temu, da lahko vzgojitelj modificira ta razvoj. Pri tem pa je vzgojitelje svarila pred vmešavanjem in prekinjanjem otrokovih vzorcev in tempa učenja. Po njenem mnenju je vzgojiteljeva naloga pripraviti okolje, primerna sredstva in materiale, nato pa naj bi se vzgojitelj umaknil v ozadje in nudil otroku dovolj časa, da vse to preizkuša. Vzgojitelj naj otrok ne bi prekinjal pri projektih, ki jih zanimajo. Montessorijeva torej vzgojitelju ne daje velike vloge v smislu poučevanja, izjemno pomembno vlogo pa ima opazovanje otrok. Po vsej verjetnosti so na to njeno prepričanje vplivale izkušnje iz medicine. Zahtevala je, da vzgojitelj ve vse, kar more, o otrocih, ki jih ima. Tako zbrane informacije so nato lahko osnova za načrtovanje otrokovega učenja.

Poudarjala je pomen aktivnega vključevanja otrok v učni proces ter podpirala zamisel načrtovanja okolja, ki ga upravlja vzgojitelj ter visoko strukturiranih navodil, kako otroke učiti. Eden od pomembnih ciljev njenega programa, ki je po njenem mnenju kazal kakovost programa, je bila zmožnost otrok, da se osredotočijo in koncentrirajo na določeno nalogo. Model Marie Montessori je še danes močno prisoten na področju organizirane predšolske vzgoje. V klasični ali pa posodobljeni obliki se je iz Evrope razširil v ZDA, Kanado, Avstralijo in Japonsko.

\section{Drugi modeli iz začetka 20. stoletja}

$\mathrm{V}$ istem času je nastala še ustanova $\gg$ nursery school $\ll-$ model organizirane predšolske vzgoje v Angliji. Sestri McMillan sta ustanovili prvo takšno institucijo v Londonu 1911. leta. Model je nastal z izrazito humanističnimi nameni pomagati revnim otrokom. Prvotno je bil usmerjen pred- 
vsem na krepitev njihovega zdravja (nega, prehrana, svež zrak in čistoča), kasneje pa so to poslanstvo razširili še z izobraževalnimi izkušnjami. Poudarjali so pomen senzornih izkušenj, vendar predvsem v dejavnostih na prostem ter $\mathrm{v}$ vsakodnevnih dejavnostih. Cenili so zlasti različne dejavnosti na vrtu, z rastlinami, zemljo, vodo, živalmi. Poleg tega pa so izjemno cenili tudi vse dejavnosti, ki so bile povezane $\mathrm{z}$ ustvarjalnostjo otrok in izrazne dejavnosti (umetnost, dramatizacija, gradnja s kockami, zgodbice in pesmi) ter reševanje problemov. Otroke so že pri petih letih učili pisanja, branja in računanja. Poslanstvo tega modela je bilo predvsem podpiranje fizičnega in mentalnega razvoja revnih otrok $s$ kvalitetami okolja, ki je bilo značilno za bogatejše sloje.

Nekoliko kasneje se srečamo tudi z drugimi modeli organizirane predšolske vzgoje. Belgijec Ovide Decroly (1861-1932) je svoj model zasnoval na kritiki ignoriranja otrokove osebnosti in njegovih interesov. Njegov moto »vzgoja za življenje skozi življenje « ${ }^{5}$ je temeljil na celostnem pristopu k otroku ter prepričanju, da je potrebno s predšolsko vzgojo pripraviti otroka za življenje, zato je $\mathrm{v}$ središče organizirane predšolske vzgoje postavil resnične predmete v otrokovem okolju, pri tem pa je proces samospoznavanja pri otrocih postavil kot pogoj za spoznavanje okolja in drugih $\mathrm{v}$ njem. Bistvo pedagoškega procesa je videl v zadovoljevanju otrokovih interesov s temami ali projekti, okrog katerih se odvija dejavnost otrok. Sistematičnosti v razširjanju otrokovega znanja ni posvečal pozornosti. $S$ to zahtevo je Decroly na nek način ustvaril protiutež zelo umetno didakticiranim pristopom Fröbla in Marie Montessori. Ob pretiranem enosmernem poudarjanju principa otrokove svobode in individualnosti so modeli, ki so se razvili iz njegovih teoretskih postavk, zašli tudi v pedocentrizem. Tudi Decrolyjeve ideje so zaznamovale sodobne pristope k vzgoji in izobraževanju predšolskih otrok, le da jih danes razumemo na drugačen način in v drugem kontekstu.

\section{Sovjetska pedagogika}

V dvajsetih letih prejšnjega stoletja se je začela razvijala tudi sovjetska pedagogika. Takratna Sovjetska zveza je po oktobrski revoluciji vzpostavila nov politični sistem, ki je vplival na vse pore takratnega življenja. Zaradi visoke stopnje zaposlovanja žensk in visoke stopnje nezaupanja v družine in s tem družinske vzgoje so organizirani predšolski vzgoji posvečali precejšnjo pozornost in jo državno financirali do takšne stopnje, da je postala tako rekoč nenadomestljiva za vsako družino. Postala je do neke

${ }^{5}$ N. B. Mčedlidze, A. A. Lebedenko, J. A. Grebenščikova, n. d. 
mere orodje kontrole družinske vzgoje, ločena od nje in večkrat tudi v vlogi »prevzgoje staršev« v smeri uresničevanja državno predpisanih ciljev. Temeljila je na strogo strukturiranih dejavnostih, $s$ katerimi naj bi dosegli predpisane cilje, povsem pa je zanemarjala individualizirane pristope in gradila na oblikovanju kolektiva. Igro in delo so strogo ločevali z uvajanjem spontane igre in usmerjenih zaposlitev. Ta koncepcija je zelo zaznamovala tudi našo organizirano predšolsko vzgojo do poznih šestdesetih let prejšnjega stoletja. Ob tem pa je potrebno poudariti, da so se tudi v sovjetski pedagogiki že zgodaj začeli oblikovati različni pogledi na otrokov razvoj in učenje. Tako je delovala skupina znanstvenikov okrog I. Pavlova (1849-1936), utemeljitelja klasičnega pogojevanja, ki je nudilo osnovo razvijanju klasične behavioristične teorije, katero sta kasneje razvila Watson in Skinner.

Druga skupina znanstvenikov pa je začela delovati okrog Vigotskega (1896-1934), ki je v tistem času že razvil svojo teorijo o kognitivnem razvoju kot rezultatu aktivne interakcije med otrokom in okoljem. Ta je že sredi tridesetih let 20. stoletja padla $\mathrm{v}$ nemilost pri tedanji sovjetski oblasti in se je ohranila oziroma razvijala le v ozkem krogu naslednikov Vigotskega. Zahodni svet pa je teoretska spoznanja Vigotskega odkril šele v šestdesetih letih, uveljavljati pa jih je začel v osemdesetih in devetdesetih letih. Ker so ideje Vigotskega močno zaznamovale sodobne pristope organizirane predšolske vzgoje, jim bomo posebno pozornost namenili v poglavju, ki opredeljuje sodobne tokove. 


\section{Obdobje socialnega nemira in poudar- jenih vplivov okolja ali obdobje dozo- revanja}

\section{Čas po drugi svetovni vojni}

as okrog 2. svetovne vojne je posebej zaznamoval tudi področje organizirane predšolske vzgoje. Hitlerjeva Nemčija je v skrbi za čistost svoje rase poskrbela tudi za posebne institucije, v katerih so vzgajali tako imenovane otroke rajha (državne otroke). Otroci, katerih starši so bili čisti Arijci, so običajno prišli v takšne institucije takoj po rojstvu. Higienski, zdravstveni in prehranjevalni režim v teh institucijah je bil v primerjavi z drugimi institucijami na mnogo višji stopnji, vendar otroci niso napredovali bolje. Še več, ob koncu vojne so s prihodom zaveznikov strokovnjaki ugotavljali, da večina teh otrok močno zaostaja za razvojem drugih, enako starih otrok. Izjema so bili le posebej ljubki in komunikativni otroci, ki so si uspeli pridobiti več pozornosti pomembnih odraslih, ki so v njihovem okolju skrbeli zanje. Ta dejstva so močno zaznamovala odnos do institucionalne vzgoje predšolskih otrok in ji dodelile še večje nezaupanje in še bolj negativni prizvok, kot ga je imela pred vojno. Tako se je povojni svet znašel v dilemi, kako poskrbeti za predšolske otroke, posebej še, ker se je v tistem času začelo bolj množično zaposlovanje mater zaradi večanja potreb po delovni sili, ki je obnavljala življenje po vojnem opustošenju.

To obdobje sta zaznamovala tudi R. Spitz ${ }^{1}$ in Bowlby, ${ }^{2}$ ki sta s svojimi raziskavami poudarjala škodljive vplive zgodnjega ločevanja otrok od ma-

${ }^{1}$ René A. Spitz, Hospitalism; An inquiry into the genesis of psychiatric conditions in early childhood, Psychoanalytic Study of the Child 1, New York 1945, 53-74.

${ }^{2}$ John Bowlby, Attachment and loss (Vol.1), New York 1969. 
ter, hkrati pa opozorila na pomen zadovoljevanja čustvenih in socialnih potreb pri otrocih ter poudarjene vloge staršev ali drugih pomembnih odraslih v otrokovem razvoju. Hkrati $s$ tem pa sta zasejala nezaupanje v javno, pa tudi v strokovno mnenje tistega časa do vključevanja otrok do tretjega leta starosti v organizirano predšolsko vzgojo (jasli).

\section{Družbena dogajanja v šestdesetih in sedemdesetih letih dvajsetega stoletja}

Obdobje so izrazito zaznamovali najrazličnejši socialni nemiri. Vse bolj je postajalo jasno, da nastajajo prepadi in neenake možnosti med bogatimi in revnimi, poglabljal se je boj za državljanske pravice ter iskanje poti za odpravljanje socialne neenakosti. Evropo so zajela množična študentska gibanja. $\mathrm{ZDA}$ so se soočale $\mathrm{z}$ gibanji proti vietnamski vojni ter gibanjem za enakopravnost državljanov ne glede na barvo kože pod vodstvom Martina Luthra Kinga. Zaradi naraščajočih pritiskov državljanov so bile vlade prisiljene prevzeti večjo odgovornost za pomoč ogroženim skupinam prebivalstva in tako nadoknaditi neenakost socialnih ali ekonomskih razmer. Ob spoznanju, da se revščina in z njo povezano neznanje pojavljata vedno v istih krogih, je postalo tudi vse bolj jasno, da revščina, nizka izobraževalna pričakovanja in neenake možnosti za izobraževanje krog revnih in neizobraženih poglabljajo in širijo, kar pa je bilo v nasprotju tudi s takratnimi potrebami razvitega dela sveta.

Iskanje novih, uspešnih in učinkovitih rešitev na področju vzgoje in izobraževanja je pogojevala tudi politična situacija $s$ »hladno vojno med ZDA in Sovjetsko zvezo. K temu pa je svoj delež prispeval tudi v tistem času izgubljen »boj za vesolje «s strani ZDA in zahodnega bloka, ko je leta 1957 sovjetski Sputnik obkrožil Zemljo. V splošnem iskanju rešitev v socialno reformskem gibanju je bila seveda tudi reforma šolstva eden od načinov, kako premostiti težave z izobraževanjem. Reforme so posegale tudi na področje organizirane predšolske vzgoje. $V$ tem času se na tem področju srečamo s tako imenovanimi kompenzacijskimi programi, ki naj bi nadoknadili razlike in izenačili startne možnosti otrok na začetku šolanja.

\section{Znanstvene usmeritve}

Obdobje je močno zaznamovalo tudi izjemno ustvarjalno in razburkano znanstveno delovanje. Šestdeseta in sedemdeseta leta prejšnjega stoletja lahko upravičeno pojmujemo kot obdobje prvega razcveta organizirane predšolske vzgoje. Znanstveniki se ponovno začnejo intenzivno ukvarjati z vplivi okolja na človekov razvoj. Leta 1961 je izšlo Huntovo delo »Intelli- 
gence and Experience $\ll,{ }^{3} \mathrm{v}$ katerem dokazuje, da je inteligenca rezultat faktorjev okolja. V tem delu poudarja tudi pomen izkušenj v zgodnjem življenju. Kasneje je tudi Bloom ${ }^{4}$ poudaril pomen izkušenj za razvoj, še posebej v obdobju hitre rasti, ko je organizem posebej občutljiv na vplive iz okolja. Oba sta zaznamovala razmišljanja in rešitve, ki so se v tem obdobju pojavile na področju organizirane predšolske vzgoje.

Programe organizirane predšolske vzgoje sta v tem času usmerjali predvsem dve nasprotujoči si filozofiji. Na eni strani so se močno okrepile behavioristične teorije, ki zagovarjajo moč vzgoje in okolja, na drugi strani pa konstruktivistično-interakcijske teorije, ki poudarjajo, da je učenje posledica interakcije med otrokovim zorenjem in vplivi iz okolja.

Oče sodobnega behaviorizma John B. Watson (1878-1958) in njegov sodobnik B.F. Skinner (1904-1990) sta verjela v to, da je vse obnašanje naučeno in da je posledica posameznikovih dejanj, ki se bodo ohranila, če bodo podkrepljena, in zamrla, če ne bodo podkrepljena. Hkrati sta zavračala idejo o fazah razvoja. Skinner na razvoj gleda kot na spremembe, ki se pojavljajo v majhnih korakih kot rezultat specifičnega pogojevanja, katerega omogočajo odrasli in okolje. Behavioristi verjamejo, da je mogoče razumeti in razložiti le vedenje, ki ga lahko opazujemo, ne verjamejo pa v teoretske pristope, ki razlagajo občutke in mentalne strukture. Učenje se po njihovem mnenju lahko kontrolira ali povzroči z manipulacijo ali kontrolo posledic, ki sledijo določenemu obnašanju s pogojevanjem. To pomeni, da posameznik lahko pogojuje drugega, da se obnaša na določen način s kontrolo nagrad ali kazni za določeno obnašanje. Takšno gledanje na otrokov razvoj seveda postavlja pred »tiste, ki vplivajo na njegov razvoj« izrazito potrebo po poučevanju in pretiranemu usmerjanju, po drugi strani pa kontrolo učenja ter manipulacijo nad vsem, kar naj bi se posameznik naučil.

Med behavioristi, ki so zaznamovali področje organizirane predšolske vzgoje velja omeniti še A. Bandura, ki je zasnoval teorijo o socialnem učenju. V svoji teoriji je razvil pomen imitacije in modeliranja za otrokov razvoj, saj se po njegovem otroci učijo tudi z opazovanjem drugih. Starši in vzgojitelji se morajo te vloge zavedati na vsakem koraku in prav tako na nek način nevtralizirati druge modele, s katerimi se otrok srečuje (npr. televizija, računalnik). Po njegovem mnenju so otroci bolj zmožni kopirati modele okrog sebe, kot pa slediti besedam.

${ }^{3}$ Joseph McVicker Hunt, Intelligence and experience, New York 1961.

${ }^{4}$ Benjamin S. Bloom, Stability and change in human characteristics, New York 1964. 
Pomemben vpliv na takratna dogajanja v vzgoji in izobraževanju lahko pripišemo tudi humanističnim psihologom, ki so zavračali tako behaviorizem kot tudi psihoanalizo oziroma njihovo poudarjanje nevrotičnega obnašanja ter nezmožnosti definiranja poti razvoja pozitivne, zdrave osebnosti. ${ }^{5} \mathrm{Na}$ kratko lahko med značilnostmi humanistične psihologije poudarimo njihovo usmerjenost $k$ proučevanju izkušenj in njihov pomen za človeka, poudarjanje določenih človeških lastnosti, kot so izbiranje, ustvarjalnost, ocenjevanje, samorealizacija, skrb za ohranjanje človekovega dostojanstva ter razvoj prirojenih potencialov, ki so v vsakem človeku. Pri tem je ena od osnovnih trditev, na kateri sloni humanistična psihologija, trditev, da človeško obnašanje motivira zadovoljevanje potreb. Humanistični psiholog A. Maslow je oblikoval teorijo razvoja osebnosti na osnovi hierarhije osnovnih potreb ter potreb razvoja oziroma rasti. Meni, da te potrebe motivirajo posameznikovo vedenje in vodijo $\mathrm{k}$ zdravemu razvoju, če so zadovoljene. ${ }^{6}$ Osnovne potrebe vključujejo fiziološke potrebe, potrebe po varnosti in preživetju. Potrebe po razvoju in rasti se pojavijo, ko so osnovne potrebe zadovoljene. Potrebe po razvoju vsebujejo potrebo po ljubezni in pripadanju ter potrebo po samospoštovanju, ki se uresničuje ob prepoznavanju, odobravanju dosežkov s strani odraslih in vrstnikov in ki vodijo $\mathrm{k}$ občutku zmožnosti. Ko so te potrebe zadovoljene, posameznik začne uresničevati druge potrebe, med katerimi je najvišje na lestvici potreba po samoaktualizaciji oziroma želja, da bi svoje sposobnosti in talente razvil do popolnosti. Motivacija za zadovoljevanje razvojnih potreb in potreb po rasti narašča, če so te zadovoljene, in pada, če niso zadovoljene. ${ }^{7}$ Tudi njegova teorija je vplivala na predšolske programe, saj morajo vzgojitelji vedeti, katere osnovne potrebe so ali pa niso zadovoljene pri otroku, če mu želijo pomagati k razvoju na zdrav način. Občutek varnosti lahko otrokom nudijo s predvidljivimi rutinskimi dejavnostmi.

Med humanističnimi psihologi velja omeniti še Rogersa, ki si razvoj razlaga kot približevanje »idealnemu jazu« ali podobi tistega, kar bi radi postali. Pri tem pa ta razvoj poteka od rigidnosti k fleksibilnosti, od statičnega $\mathrm{k}$ procesnemu, od odvisnosti $\mathrm{k}$ avtonomnosti, od predvidljivega do nepredvidljivo kreativnega, od obrambnega ravnanja k samosprejemanju. ${ }^{8}$ Rogers je zaznamoval institucionalno predšolsko vzgojo predvsem s svojim pojmovanjem razvoja od odvisnosti $\mathrm{k}$ avtonomnosti ter poudarjanjem po-

\footnotetext{
${ }^{5}$ R. M. Thomas, Comparing Theories of Child Development, Belmont 1992.

${ }^{6}$ Abraham H. Maslow, Toward a psychology of Being, New York 1968.

${ }^{7}$ A. H. Maslow, Motivation and Personality, New York 1970.

${ }^{8}$ R. M. Thomas, Comparing Theories of Child Development, Belmont 1992, 413.
} 
membnosti osebne izkušnje. Tako je izkustveno učenje pridobilo novo dimenzijo v osebno pomembnem ali signifikantnem učenju.

Nasprotnikom behaviorizma se je pridružila tudi kritika t. i. teorije kulturnega relativizma, ki zagovarja izjemno spremenljivost kulturnih norm ter izjemno prilagodljivost človeške narave. Erich Fromm je v tem času že podal obširno kritiko teh gledanj. ${ }^{9}$ Fromm zagovarja tezo, da je človekova narava sicer prilagodljiva, ne pa absolutno raztegljiva, saj človek v izjemno neugodnih razmerah razvije obrambne mehanizme in nanje reagira z negativnimi čustvi, ki lahko vodijo tudi do obolenj. Prav tako pa kultura ni statičen, nespremenljiv dejavnik, neodvisen od človekove dejavnosti. Če kultura ogroža človekovo bistvo, predvsem njegove socialne potrebe, kot so potreba po varnosti, ljubezni, samostojnosti, po razvoju svojih sposobnosti, po svobodi, uveljavljanju, iskanju smisla življenja, ga prisilijo k spreminjanju socialno-kulturnih faktorjev. In prav s tem je po njegovem mnenju omogočen človeški razvoj, saj bi sicer človek postal le pasivna lutka v rokah družbenih in kulturnih ureditev, hkrati pa bi izgubil kriterije za presojanje humanosti ter motive za spreminjanje kulture in svojo ustvarjalnost. Pedagogika bi ostala brez svoje naravnanosti, da vidi v otroku predvsem človeka, ki se razvija v samostojno osebnost in individualnost; ${ }^{10}$ ostala bi brez otroka.

\section{Erik Erikson}

V začetku 60. let je začelo naraščati tudi zanimanje za teorijo razvoja Erika Eriksona (1902-1994), ki jo nekateri avtorji razporejajo med psihoanalitične, ${ }^{11}$ drugi pa med psihosocialne teorije. ${ }^{12}$ Erikson je kot Freudov učenec svojo teorijo razvoja sicer začel graditi na psihoanalitični psihološki teoriji, pri tem pa je Freudove psihosocialne faze tolmačil tako, da je biološkim dejavnikom razvoja namenil manj pomembnosti, veliko več pa interaktivni naravi razvoja. Tako Erikson verjame, da otrok igra aktivno vlogo v oblikovanju svojih izkušenj $s$ tem, kako vstopa v interakcijo $s$ svojim okoljem. Poudarjal je pomen razvojnih potreb kot sredstva zato, da bi razumeli, kakšno naj bi bilo starostno primerno socialno in emocionalno obnašanje.

\footnotetext{
${ }^{9}$ Erich Fromm, Zdrava družba, Ljubljana 1970.

${ }^{10} \mathrm{M}$. Bergant, Teme iz pedagoške sociologije, Ljubljana 1970.

${ }^{11}$ C. Seefeldt, N. H. Barbour, Early Childhood Education, Merrill 1994.

${ }^{12}$ Pauline H. Turner, TommieJ. Hamner, Child development and Early Education. Infancy Trough Preschool, Boston, London, Toronto, Sydney, Tokyo, Singapore 1994; M. R. Jalongo, J. P. Isenberg, Exploring Your Role - A Practitioner's Introduction to Early Childhood Education, Merrill 2000.
} 
Erikson poudarja, da poteka razvoj skozi življenje v seriji nivojev. $\mathrm{Na}$ vsak nivo po eni strani vplivajo drugi in vsak nivo vpliva na druge. Po Eriksonu poznamo osem stopenj razvoja (glej preglednico 1).

\begin{tabular}{|c|c|c|}
\hline Starost & Stopnja & Idealen rezultat - moč ega \\
\hline $0-1$ & Zaupanje proti nezaupanju & Upanje \\
\hline $2-3$ & Avtonomija proti sramu in dvomu & Volja \\
\hline $4-5$ & Iniciativa proti krivdi & Namernost \\
\hline $6-12$ & Marljivost proti manjvrednosti & Kompetentnost \\
\hline Adolescenca & Identiteta proti identitetni zmedi & Zvestoba \\
\hline Mladi odrasli & Intimnost proti izolaciji & Ljubezen \\
\hline Srednja leta & Generativnost proti stagnaciji & Skrbnost \\
\hline Starost & Integracija ega proti obupu & Modrost \\
\hline
\end{tabular}

Preglednica 1: Stopnje psihosocialnega razvoja po Eriksonu. ${ }^{13}$

Za vsako od stopenj je značilna določena kriza, ki vpliva na naš socialni razvoj in hkrati odseva določeno kulturo, ki je enkratna za vsakega posameznika. Okolje delno zadovoljuje potrebe posameznika in mu hkrati postavlja svoje zahteve, kar povzroča določen konflikt oziroma psihosocialno krizo. Vsako krizo mora posameznik razrešiti, da bi dosegel idealni rezultat kot posledico razvojne borbe, ki se konča na določeni stopnji in bi se tako pripravil za spoprijem s krizo na naslednji stopnji razvoja. Po njegovem mnenju je za zdravo, trajno socialno interakcijo potrebno uspešno rešiti razvojno krizo, s katero se srečuje posameznik. Prepričan je, da način reševanja socialne krize vpliva na posameznikova stališča in spretnosti.

V praksi predšolske vzgoje je Eriksonova teorija izjemno pomembna predvsem zato, ker poudarja pomen odraslih pri zadovoljevanju otrokovih potreb po toplini, ljubezni, skrbi. Odrasli postanejo otroku socialno emocionalni model in imajo zato izjemno pomembno vlogo pri učenju socialno interakcijskih občutkov in čustev ter zmožnosti. Prav tako pa poudarja igro kot sredstvo za možnost izbire in odločanja, kar pri otroku poveča občutek avtonomnosti in zmožnosti.

\section{Jean Piaget}

Zanesljivo pa je to obdobje najbolj zaznamovalo zanimanje in aplikacija kognitivno-razvojne teorije J. Piageta. Ta je predstavljala osnovo interak-

${ }^{13}$ Prirejeno po: C. G. Mooney, Theories of Childhood, Minnesota 2000. 
cijsko-konstruktivističnega pojmovanja odnosa med dednostjo in okoljem in spoznanju, da je razvoj dinamičen proces, v katerem vse, kar je dednega, vpliva na okolje in obratno ter da je učenje posledica interakcije med zorenjem in vplivi okolja, ki se kombinirajo na zelo kompleksen način. $\mathrm{Na} \mathrm{Pi}$ ageta so vplivala dela Rousseauja, ki je gledal na otroka kot na aktivno bitje, vendar je Piaget koncept naravnega razvoja dopolnil s predpostavko, da otrok znanje gradi v interakciji s socialnim in fizičnim okoljem. To interakcijo je Piaget poimenoval asimilacija, akomodacija in ekvilibracija. Ko je otrok v interakciji, si oblikuje sheme oziroma organizacijske vzorce, ki so osnova za bolj zapletene strukture. $Z$ asimilacijo vsrkava novo snov v že obstoječe strukture, $\mathrm{z}$ akomodacijo se obstoječe strukture spremenijo, tako da odgovarjajo oziroma vključijo nove situacije. Oba procesa potekata hkrati in se prepletata. Tretji proces, ekvilibracija, pa temelji na predpostavki, da organizem teži k dinamičnemu ravnovesju med že obstoječimi struktura$\mathrm{mi}$ in novimi dogodki. $\mathrm{V}$ tem procesu pa otroci izumijo najbolj učinkovito pot za ravnanje v okolju.

Piaget je postavil teorijo faz otrokovega intelektualnega razvoja in predpostavlja, da poteka kognitivni razvoj pri vseh otrocih skozi serijo štirih faz (senzomotorična, predoperativna, konkretno operativna in faza formalnih operacij). Piaget je svojo teorijo osnoval na štirih osnovnih podmenah o otrokovem kognitivnem razvoju:

1) Biološki vplivi in vplivi okolja so v stalni interakciji, da bi se razvile sposobnosti mišljenja, sklepanja in zaznavanja.

2) Kognitivni razvoj je v osnovi rezultat neposredne izkušnje v okolju; otroci so šele sčasoma zmožni transformirati svoje izkušnje na mentalnem nivoju s pomočjo notranje refleksije.

3) Hitrost razvoja posameznika je pogojena s socialnim okoljem.

4) Kognitivni razvoj prinaša glavne kakovostne spremembe v mišljenju posameznika.

Piaget sam nikoli ni imel namena prenašati svoje teorije v prakso predšolskih programov. To so storili njegovi sodobniki in pri tem seveda vsak po svoje, iz svojega zornega kota, uporabljali Piagetovo teorijo kot izhodišče določenih pedagoških rešitev (predvsem vzorcev interakcije med odraslim in otrokom) ali celega programa (npr. program Educating the Young Thinker ${ }^{14}$ ). Vendar je njegova teorija močno vplivala na naše vedenje o tem, kaj naj bi vzgojitelj počel, da bi podpiral otrokov intelektualni razvoj. Njegove ideje so vplivale tudi na prepričanje o tem, da bi vrtci morali po-

${ }^{14}$ Povzeto po: M. R. Jalongo, J. P. Isenberg, n. d. 
nujati veliko število raznovrstnega materiala in izkušenj za vse otroke, da bi morali otroci imeti možnost dostopa do različnih materialov, ki so primerni za različne razvojne stopnje in so hkrati vredni otrokove pozornosti. Ti materiali pa morajo otroka tudi izzivati k igri, pridobivanju izkušenj o simbolih, reševanju problemov, dogovarjanju, odločanju in urjenju novih spretnosti v varnem okolju. ${ }^{15} \mathrm{Ob}$ pridobivanju motoričnih izkušenj, raziskovanju, eksperimentiranju, testiranju hipotez in refleksiji bo otrok razvijal mišljenje.

\section{Head Start}

V skrbi za zmanjšanje razlik iz tega obdobja je zanesljivo najbolj znan primer takšne naravnanosti ameriški projekt War on Poverty (Vojna proti revščini), ki ga je leta 1964 začel takratni predsednik L. Johnson in so ga sestavljali različni podprojekti. Sestavni del enega od teh podprojektov, ki je zadeval akcijske programe v lokalnih skupnostih, pa je bil tudi Head Start program. Ta program je pogosto poenostavljeno razumljen kot en, enoten program v smislu tega, kar se je dogajalo v organizirani predšolski vzgoji. Taka naivna poenostavitev je programu prinesla izjemno veliko škode tudi na področju raziskovanja učinkov teh programov, saj so rezultate $\mathrm{v}$ začetni fazi posploševali, ne glede na vrsto programa in socialne značilnosti otrok, ki so bili v te programe vključeni. Enotnost tega programa se kaže le v osnovnih izhodiščih, kot sta npr. nujnost vključevanja staršev in vključevanje otrok v organizirano predšolsko vzgojo vsaj eno leto pred začetkom šolanja.

Na izvedbenem nivoju se je uresničevanje programa Head Start zelo razlikovalo. Spodek in Clark Brownova ${ }^{16}$ navajata štiri temeljne pristope, $s$ katerimi so v praksi organizirane predšolske vzgoje uresničevali Head Start program:

- Montessori pristop,

- behavioristični pristopi,

- pristopi odprte vzgoje,

- konstruktivistični pristopi.

Takšna porazdelitev že sama po sebi pove, da je v realizaciji Head Start programa prihajalo do razlik v teoretskih osnovah, oziroma v razvojni te-

\footnotetext{
${ }^{15}$ Sue Bredekamp, Carol Copple, Developmentally appropriate practice in early childhood programs, Washington 1997.

${ }^{16}$ B. Spodek, Patricia Clark Brown, Curriculum Alternatives in Early Childhood Education: A Historical Perspective, New York 1993.
} 
oriji, ki je usmerjala določen pristop. Razlike so bile tudi v ciljih. Behavioristični pristopi so poudarjali predvsem pripravo na šolo, konstruktivistični pa predvsem razvoj kognitivnih procesov. Pristopi odprte vzgoje so običajno imeli bolj široke cilje, poleg priprave na šolo in razvijanja kognitivnih procesov so poudarjali razvijanje sposobnosti izražanja ter vseh vrst osebne avtonomije. $V$ pristopih Montessori pa je bilo zaslediti tako ortodoksno kot posodobljeno metodo. Ne glede na povedano pa danes velja, da so bili vsi ti programi preveč usmerjeni na razvijanje tistih zmožnosti otrok, ki so pomembni za osvajanje akademskih znanj na začetku šolanja in so vse preveč enostranski z vidika celostnega razvoja otrok.

Head Start program se je uresničeval tako v privatnih in državnih predšolskih ustanovah kakor tudi v cerkvenih in laičnih. Velik optimizem v odnosu do uspešnosti kompenzativnih programov, ki naj bi v enem letu organizirane predšolske vzgoje nadoknadil vse primanjkljaje, izhajajočih iz socialne ali ekonomske diferenciacije, je seveda kmalu zamrl, ko so prvi rezultati o vplivu teh programov obšli svet $\mathrm{z}$ ugotovitvijo, da začetni pozitivni učinki kmalu zamrejo, običajno že v drugem letu šolanja. Izkušnje z uvajanjem Head Start programa pa so prinesle kar nekaj izjemno pomembnih spoznanj za nadaljnji razvoj organizirane predšolske vzgoje.

Povsem jasno je postalo, da vsi otroci iz depriviligiranih slojev niso ena$\mathrm{ki}$, ampak imajo zelo različne potrebe. Organizirana predšolska vzgoja se je začela zavedati pomena vključevanja staršev v razvojni proces otrok (tudi v okviru organizirane predšolske vzgoje). Končno je bilo ugotovljeno tudi to, da so kompenzacijski programi lahko učinkoviti, če jih začnemo uvajati pred otrokovim petim letom starosti oziroma po načelu »čim prej tem bolje «. Na tej osnovi so kasneje nastale nove iniciative intervencijskih programov za najmlajše otroke v starosti do tretjega leta. Leta 1967 so za nadgradnjo Head Start programa v zadnjem letu predšolske vzgoje in na začetku osnovne šole uvajali Follow Through program, ki je kasneje predvsem skozi proces vnašanja inovacij v šolo izoblikoval široko mrežo strokovnjakov in alternativnih modelov šolanja.

Raznolikost programov oziroma teoretskih pristopov, ki so nastajali v tem obdobju, se kaže tudi v vlogi, ki jo posamezni programi dajejo vzgojitelju oziroma otroku. Pri tem seveda ne gre pozabiti, da je ta vloga odvisna predvsem od tega, kako pojmujemo otrokov razvoj in učenje. Če pojmujemo učenje kot sprejemanje informacij in vrednot oziroma transmisijo, potem je povsem normalno, da ima vzgojitelj (in učna snov, ki jo mora vzgojitelj predelati z otroki) v vzgojno-izobraževalnem procesu osrednjo vlogo načrtovalca in iniciatorja. $V$ primeru pa, ko pojmujemo učenje kot interak- 
tivni in socialni proces, ki poteka med otrokom in okoljem, otrokom in drugimi otroki ter otrokom in odraslimi, govorimo o $\gg$ na otroka osredotočenih pristopih « oziroma učenju. $S$ to raznolikostjo v pristopih se srečujemo tudi v tem obdobju. Vsi behavioristični pristopi so temeljili na pristopih, ki so bili usmerjeni na vzgojitelja ali učno snov, pri konstruktivističnih pristopih pa je osrednja vloga v procesu učenja namenjena otroku, zato govorijo o učenju in pristopih, ki so osredotočeni na otroka.

$\mathrm{Na}$ vsak način pa lahko trdimo, da je prav to obdobje zaradi izjemnega širjenja organizirane predšolske vzgoje prineslo področju dokončno veljavo. K temu so seveda močno prispevala tudi različna ženska gibanja, ki so hote ali nehote povezana s področjem organizirane predšolske vzgoje. $\mathrm{Ob}$ zagotavljanju enakih možnosti za ženske se namreč vedno poveča potreba po organizirani predšolski vzgoji, hkrati pa tudi zahteva, da je ta dejavnost kvalitetna.

\section{Kaj se je dogajalo pri nas}

$\mathrm{V}$ tem obdobju, predvsem v sedemdesetih letih, tudi pri nas zasledimo intenzivno zanimanje za vplive okolja na otrokov razvoj in učenje. Tudi pri nas smo skušali med drugim zmanjšati vplive socialne diferenciacije z vzpostavitvijo tako imenovane obvezne priprave na šolo ali male šole leto dni pred vstopom v šolo. Pri tem je bila priprava na šolo za otroke, ki so bili vključeni v redni dnevni program vrtca, vključena v te dejavnosti, za otroke, ki niso obiskovali vrtca, pa je država zagotavljala minimalni program priprave na šolo v obsegu približno 200-250 ur letno. Kmalu pa je bilo zaslediti diferenciacijo tudi v tem pogledu, saj so ekonomsko bolj razvita področja zagotavljala program male šole v večjem obsegu, včasih tudi v enkrat večjem obsegu. Tudi ciljna naravnanost teh programov je bila usmerjena na pripravljanje otrok za dejavnosti v šoli. Kontinuiteta med vrtcem in šolo je bila izpeljana predvsem iz vsebine in ciljev šolskega dela, ne pa iz razvojnih potreb otroka $v$ tem obdobju.

Tudi pri nas lahko govorimo o razcvetu dejavnosti in širitvi dejavnosti, verjetno tudi po zaslugi uvedbe samoprispevka občanov za izgradnjo novih vrtcev in šol. Soodločanje občanov v programu organizirane predšolske vzgoje pa je bilo delno uresničeno preko svetov, čeprav je ostajalo bolj na formalni ravni. Načeloma pa so naši vrtci še vedno težko sprejemali in odpirali svoje programe staršem. Visoki higienski standardi so staršem prepovedovali vstop v igralnice oziroma v svet otrok, razen seveda ob skupnih roditeljskih sestankih. Starše smo vključevali v svete staršev, vendar je bil tudi v tem primeru njihov dejanski vpliv razmeroma nizek. Struktura in 
organizacija življenja v vrtcih je bila še močno pod vplivom industrijskega modela. Dnevni red v vrtcu je predvideval predpisan čas za določene dejavnosti, informacije so se v otroške glave zlivale fragmentarno, ločeno, razdrobljeno na manjše delce, zato da otrok ne bi preveč obremenjevali. Vsebina in končni proizvodi so bili vnaprej določeni tako, da jih je bilo mogoče kontrolirati s strani države. Kontrola kakovosti je bila omejena predvsem na pregled dokumentacije ter uresničevanje ciljev (na papirju) oziroma ujemanje zapisanih dejavnosti v dokumentih $s$ tistim, kar so vzgojiteljice izvajale v oddelku. Skrb za strokovni razvoj vzgojiteljic je bila razdrobljena in prepuščena odločitvam vodstva. Te odločitve pa so bile po eni strani odvisne od strokovne osveščenosti vodstva, po drugi strani pa tudi od finančnih virov, ki so jih v posameznih okoljih zagotavljali v ta namen. 



\section{PREDŠOLSKA VZGOJA V IZZIVIH DRUŽBE KONEC 20. IN V ZAČETKU 21. STOLETJA}





\section{Spremembe v \\ družbi in njihov \\ vpliv na vzgojo \\ in izobraževanje}

P

otreba po korenitih spremembah na prelomu tisočletja tudi na področju predšolske vzgoje izhaja iz velikih sprememb v družbi, vdora poplave informacij v vsakodnevno življenje, potrebe po spreminjanju vloge tradicionalnih institucij ${ }^{1}$ in sodobnih spoznanj o človeku, njegovem razvoju in $\gg$ ustroju $\ll .{ }^{2}$ Razumevanje teh sprememb nam nudi tudi osnovo za razumevanje dogajanj na področju predšolske vzgoje, zato jim bomo namenili posebno pozornost.

Drucker opozarja, da se svet trenutno giblje v eni od večjih socialnih preobrazb, do katerih prihaja le vsakih nekaj sto let. ${ }^{3}$ Hkrati meni, da bodo te spremembe najbolj občutile prav vzgojno-izobraževalne institucije. Pri tem se bodo zlasti pedagogi morali neprestano odzivati z osvajanjem novih znanj in veščin na področjih, za katere so bili formalno že usposobljeni. Vse bolj bodo prisiljeni znati uporabljati nove diagnostične, spremljevalne in ocenjevalne mehanizme, $s$ katerimi bodo bolj natančno ugotavljali začetne nivoje in potrebe otrok in iz tega izhajajoče pristope $\mathrm{k}$ učenju in poučevanju v oddelku. Osamljenost pedagoga znotraj oddelka bo zamenjalo intenzivno delo v timu; vse več časa bo posvetil pripravi, ocenjevanju vhodnih točk, načrtovanju razvoja ter njegovemu sledenju in rezultatom. Njegov strokovni razvoj pa bo moral potekati kontinuirano ves čas njegovega strokovnega dela.

\footnotetext{
${ }^{1}$ Malcolm Skilbeck, The utility of early childhood education, Worcester 1992.

${ }^{2}$ Howard E. Gardner, The unschooled mind, New York 1991; Peter Russell, Knjiga o možganih, Ljubljana 1993; Renate Nummela Caine, Geoffrey Caine, Making connections: Teaching and the human brain, Alexandria 1991; R. N. Caine, G. Caine, Education on the edge of possibility, Alexandria 1997.

${ }^{3}$ Peter F. Drucker, Post-capitalist society, New York 1993.
} 
Na pragu 21. stoletja se v razvitih družbah, ki pa kljub vsemu predstavljajo manjšino človeštva, srečujemo s stalnimi, hitrimi in korenitimi spremembami, ki močno vplivajo na vse pore tega dela človeške družbe. Nobelov nagrajenec na področju ekonomije dr. Fogel poudarja, da je podaljšanje življenjske dobe ter zmanjševanje rodnosti v zadnjih štiridesetih letih večje kot $\mathrm{v}$ štiritisočletni zgodovini človeštva. ${ }^{4}$

\section{Od industrijskega modela izobraževanja k modelu ustvarjalne delavnice oziroma ateljeju}

Ena od poglavitnih nalog vzgoje in izobraževanja pri odzivih na stalne spremembe je zanesljivo tudi zagotavljanje možnosti za vseživljenjsko izobraževanje. Po nekaterih predvidevanjih je okrog 75 odstotkov poklicev, ki naj bi jih ljudje v razvitih družbah opravljali v drugi polovici 21. stoletja, danes še povsem neznanih. ${ }^{5}$ Takšno predvidevanje postavlja vzgoji in izobraževanju v ospredje vprašanja $\gg$ kaj in kako učiti za danes in za prihodnost «. Vse bolj postaja pomembno učenje za razvijanje uspešnega obvladovanja problemov v neprestano spreminjajočih se življenjskih pogojih in adaptacijskih sposobnosti na nove življenjske pogoje oziroma na situacije, na predvidevanja sprememb in aktivno ter ustvarjalno soočanje z njimi. V tem okviru je seveda nadvse pomembno razvijati tudi socialno zavest.

Johnson in Johnson ${ }^{6}$ menita, da so socialne spretnosti neposredno povezane z izgradnjo in vzdrževanjem trdnih odnosov ter psihičnega zdravja. Csikszentmihaly navaja, »da moramo krepiti intuicijo, da bi predvideli spremembe še pred tem, ko se te pojavijo, empatijo, da bi razumeli tisto, kar ni mogoče jasno izraziti, modrost, da bi videli povezavo med tistim, kar zgleda nepovezano, in ustvarjalnost, da bi odkrivali nove poti pri definiranju problemov ter nova pravila, ki bodo omogočala, da jih prilagodimo nepričakovanemu ${ }^{7}{ }^{7} \mathrm{Za}$ tako kompleksne cilje pa stari modeli vzgoje in izobraževanja, ki so temeljili na transmisiji tradicionalnega znanja in vrednot ter na ideji izobraževalne institucije kot pripravljalnice za življenje, niso več primerni. Skupaj s spoznanjem, da novi časi zahtevajo drugačne pristope $\mathrm{k}$ učenju, nastane tudi ideja o potrebi po preraščanju industrijskega modela vzgojno-izobraževalnih institucij.

\footnotetext{
${ }^{4}$ Robert W. Fogel, Early Childhood Counts - A Programming Guide on Early Childhood Care for Development, Washington 2000.

${ }^{5}$ R. N. Caine, G. Caine, Making connections, Teaching and the human brain. Innovative learning publications, New York 1994.

${ }^{6}$ David W. Johnson, Roger T. Johnson, Conflict resolution and peer mediation programs in elementary and secondary schools, Minnesota 1996, 459-506.

${ }^{7}$ Mihaly Csikszentmihalyi, The evoking self: A psychology for the third millennium, New York 1993, 42.
} 
Caine in Caine opozarjata, ${ }^{8}$ da je tradicionalni model organizacije in delovanja institucij za izobraževanje do konca 20. stoletja temeljil na modelu tovarne. Ker je množično šolanje pojav, povezan z nastankom industrializacije in s potrebo po »delno « usposobljeni delovni sili, je to na področje vzgoje in izobraževanja prineslo predvsem skrb za oblikovanje delovne sile v tovarnah oziroma proizvodnji. $V$ tradicionalnih tovarnah so izdelki narejeni na tekočem traku, pri tem pa je končni rezultat oziroma produkt kombinacija $\mathrm{z}$ lahkoto prepoznavnih delov, ki so narejeni z uporabo natančno določenih in merljivih materialov. Delo je bilo opravljeno po vnaprej določenem zaporedju, z opredelitvijo začetka, odmorov in konca. Hitrost, točnost in količina izdelkov so bili nagrajeni. Življenje na delovnem mestu je bilo stabilno in predvidljivo. Podobno so po njunem mnenju delovale tudi institucije za vzgojo in izobraževanje. Menita, da je bilo povsem naravno, da so vzgojno-izobraževalne institucije v preteklosti prevzele in osvojile tak industrijski model delovanja tovarne kot smernico učinkovitega izobraževanja. S tem so se vzgojno-izobraževalne institucije odzivale na potrebe tedanje družbe.

$\mathrm{Za}$ industrijski model vzgoje in izobraževanja je bilo značilno, da se je vsak predmet ali področje dejavnosti poučeval ločeno, otrok pa se je gibal skozi predmete in po urniku kot na tekočem traku. Čas in kraj učenja, pa tudi odmori, so bili določeni na osnovi potreb po pokrivanju določenih predmetov oziroma na osnovi učnih načrtov, ne pa na osnovi otrokove pripravljenosti za učenje. Učinki so bili določeni s standardi znanja, s spretnostmi in podatki, ki jih je relativno lahko testirati. Pomembne odločitve so sprejemali posamezniki, ki so dosegli določeno avtoriteto za ocenjevanje opravljenega dela. Notranjo povezanost med predmeti oziroma področji je bilo mogoče zaslediti le izjemoma.

Model tovarne je nudil ustrezno osnovo za behavioristične pristope $\mathrm{k}$ učenju. Ti pristopi so $\mathrm{v}$ preteklih petdesetih oziroma šestdesetih letih predstavljali prevladujočo prakso na področju vzgoje in izobraževanja. Temeljijo na predpostavki, da je to, kar se učimo, mogoče reducirati na specifične, $\mathrm{z}$ lahkoto prepoznavne dele in da nagrado in kazen lahko uporabimo kot gonilno silo v smeri želenega učenja. Ti pristopi so zanikali notranje življenje otroka oziroma učenca in njegove zmožnosti, da oblikuje osebno in intelektualno pomembne pomene. Behaviorizem v vzgojno-izobraževalnem procesu je v veliki meri temeljil na nagrajevanju in kaznovanju. Smejoča nalepka, srček ali zvezdica, ki jo je otrok prejel kot nagrado za določeno dejanje, pa ni le to, ampak vpliva na oblikovanje otrokovih pričakovanj, na-

${ }^{8}$ R. N Caine, G. Caine, n. d., 13. 
vad, preferenc. Ko so kazni in nagrade nadzorovane s strani drugih, večina otrok hoče in pričakuje navodila in odgovore od drugih in so tako demotivirani za naravno iskanje pomena. Zato imamo danes še vedno celo generacijo, ki se uči za ocene in nagrade. Sistem vprašanj in razlage je temeljil na vnaprej določenih pravilnih odgovorih in rezultatih. Za vsako spretnost, ki jo v resnici osvojimo, pa je potrebno, da oblikujemo svoj lasten pomen in lasten smisel ter to v svojih možganih organiziramo na svoj lasten način. To je mogoče le, če imamo za to določeno množico ustvarjalnih priložnosti. Če pa so vse možnosti vnaprej določene, otroke oziroma učence prikrajšamo za možnost narediti nekaj ustvarjalnega, kar je nujno za pravo učenje. Na ta način jih potisnemo nazaj na nivo pomnjenja.

Nekako v začetku 80. let prejšnjega stoletja se začne potreba po spremembi tega tovarniškega modela $z$ opozarjanjem na neprimernost enoumja v poučevanju. Overly je tako opozarjal, da je šolanje slaba podpora učenju, ker vztrajanje na učenju kot produktu oziroma učenju, usmerjenemu samo na rezultat, ovira pomembno učenje, ki je povezano s kompleksnimi procesi, kot sta raziskovanje in presoja. Šolanje pogosto razdeli učenje v predmete, nadomešča naravno željo po učenju s kontrolo, naravno aktivnega otroka pa postavlja za ure v strukture tekočega traku v oddelku, ignorira individualne in kulturne razlike med otroki ter podcenjuje ali zanemarja učne možnosti za učenje od drugih starejših in mlajših vrstnikov ter odraslih. ${ }^{9}$

\section{Globalizacija in medkulturni dialog}

Hkrati s tehnološkim razvojem prihaja $v$ razvitem svetu do odpiranja novih trgov in meja, ki prispevajo $\mathrm{k}$ vse večji mobilnosti prebivalstva. Ta sprememba zahteva ustvarjalno prilagajanje novo nastalim razmeram in pogojem življenja $\mathrm{v}$ različnih jezikovnih in kulturnih sredinah. Vse to pa po eni strani spet zahteva skrb za lastno identiteto in toleranco oziroma spoštovanje drugačnosti po drugi strani. Oboje pa postaja osrednji cilj in oboje je potrebno uravnovesiti tudi v procesu vzgoje in izobraževanja. Medveš $^{10}$ opozarja na nujnost sprememb na nivoju ciljev vzgoje, ki terjajo strpnost in sožitje, sposobnost znajti se v situacijah, ozaveščanje sebe in drugih kot različnih in tako ustvarja možnosti sožitja v različnosti. Hkrati opozarja tudi na potrebo po spremembi koncepta vzgoje in izobraževanja $\mathrm{v}$ smeri vse večjega pomena procesa v primerjavi s produktom. Vse to prinaša na področje izobraževanja nove izzive.

\footnotetext{
${ }^{9}$ Overly, povzeto po: R. N Caine, G. Caine, n. d.

${ }^{10}$ Zdenko Medveš, Pedagoška etika in koncept vzgoje (1. del), Sodobna pedagogika 42 (1991), 3-4, 101-107.
} 
Z odpiranjem trgov, s tehnološkim napredkom, z ekonomskimi, socialnimi in političnimi spremembami, ki se hitro širijo po vsem svetu, je povezan tudi proces globalizacije. Morda pojem še najbolje opišemo z dejstvom, da celoten svet postaja »velika svetovna vas «. Globalizacija prinaša izzive na nivoju integritete in identitete posameznika in naroda.

Proces globalizacije je seveda prisoten tudi na področju vzgoje in izobraževanja. Povsod v razvitem svetu se srečujemo s cilji, povezanimi z vseživljenjskim izobraževanjem in »učečo se skupnostjo«, s poudarjanjem kakovosti izobraževanja pa tudi z določenimi vrednostno obarvanimi cilji, ki naj bi jim sledili v procesu izobraževanja, kot so: kritičnost, odgovornost, samostojnost, strpnost, sodelovalnost, skrbnost v odnosu do ljudi in narave ter demokratičnost. Te nove cilje pa je v bistvu nemogoče doseči z ustaljenimi, tradicionalnimi pedagoškimi koncepti oziroma vzorci. Pedagoški koncepti, ki se odzivajo na nastale spremembe, morajo biti bogatejši, bolj fleksibilni in odprti za to, da dovoljujejo otrokom več svobode za rabo njihovih individualnih strategij mišljenja in osebnih mnenj za konstruiranje, širjenje in poglabljanje pojmov ter za premagovanje problemov. Spodbujati morajo rabo sposobnosti na izviren in domiseln način pa tudi iniciativnost, odgovornost ter presojanje in uporabo naučenega $\mathrm{v}$ novih situacijah in pri reševanju novih nalog oziroma problemov. Vzgoja in izobraževanje lahko odgovorita na izzive globalizacije s krepitvijo sposobnosti za konkurenčnost na svetovnem trgu pa tudi s spoštovanjem in priznavanjem različnih kultur, da bi zaščitili narodno identiteto.

\section{Pripravljenost na spremembe}

Današnji otroci se bodo skozi vse svoje življenje soočali s spremembami na socialnem in političnem področju, s spremembami okolja, s spremembami v znanosti in v tehnologiji ter industriji, z njihovimi vplivi na trg zaposlovanja in končno s spremembami vzorcev družinskega življenja. Zato se povsod $\mathrm{v}$ razvitem svetu znova poudarjata pomen vzgoje in izobraževanja in zahteva po njunem hitrejšem odzivanju na spremenjene pogoje življenja. Šola se kot institucija zelo težko odziva, prilagaja in pripravlja na nov tip učenca, saj se na tem področju še vedno srečujemo z razdrobljenim izobraževanjem in $\mathrm{z} \gg$ izobraževanjem na tekočem traku«, ki v resnici onemogočata razumevanje povezanosti med učenjem in življenjem, kar je za kompleksno učenje nujno.

Hiter tehnološki razvoj, kateremu smo mu priča, pa tudi tisti, ki ga šele slutimo, prinaša v vzorce življenja neprestane spremembe. $Z$ vdiranjem informatike v naše vsakodnevno življenje nastaja poplava informacij, ki hkra- 
ti prinaša spoznanje o pomenu in dostopnosti informacij. Razlike med posamezniki so vse bolj določljive tudi z vidika tega, koliko ima posameznik možnosti za dostop do informacij, kako obvladuje vire informacij in kako zna informacije selekcionirati. Resnick meni, ${ }^{11}$ da bo uspeh posameznikov ali družb v 21. stoletju odvisen predvsem od tega, kakšen bo njihov dostop do informacij in $\mathrm{v}$ sposobnosti procesiranja teh informacij. Posamezniki, skupine in družbe, ki bodo ta dostop imele, bodo po njegovem mnenju tudi najbolj uspešne. Nič manj pomembna pa ni potreba po tem, da se sodobne generacije naučijo selekcionirati informacije ter uporabljati različne vire in različne informacije. Množica informacij, ki jim je in ki jim bo posameznik izpostavljen, sama po sebi torej še zdaleč ne zadostuje za njegovo uspešnost $v$ družbi. Informacije bo moral selekcionirati in razumeti ter ponotranjiti vsebino $\mathrm{v}$ tolikšni meri, da mu bo na voljo spontano in $\mathrm{v}$ različnih kontekstih.

Ena od funkcij vzgojno-izobraževalnega procesa je tudi pripravljati otroka za resnično življenje, zato je potrebno model vzgojne institucije uskladiti z resničnim življenjem, ki ga otroci oziroma učenci živijo. Današnji otroci rastejo skupaj z elektronskimi čudeži, ki vplivajo nanje na zavednem in nezavednem nivoju. Vplivajo na njihovo osebnost in na njihove vrednote. Obseg njihovega znanja, ki si ga na ta način pridobivajo, se sicer lahko veča, vendar je večina teh medijev usmerjena v enosmerno komunikacijo. Otroci so tako prikrajšani za postavljanje vprašanj, oblikovanje svojih lastnih mnenj, reševanje problemov, za preverjanja svojih pogledov ipd. Otroci imajo vse manj možnosti učiti se o skrbi, skrbeti zase in za druge, o tem, kako prevzemati odgovornost in o tem, da uresničitev želja in sanj terja napor in čas.

Včasih je večino teh funkcij prevzela družina, toda tudi ta se v sodobnem svetu spreminja. Vse več otrok ima oba starša zaposlena, veliko jih odrašča v enostarševskih družinah; otroci preživijo vse manj časa skupaj $s$ starši v tistem pravem interakcijskem pomenu. Caine in Caine navajata, ${ }^{12}$ da ameriški otroci v prvih šestnajstih letih življenja preživijo pred televizorjem šestkrat dlje kot pa v druženju s svojimi starši. Čeprav so tudi naši otroci izpostavljeni tem vplivom, pa na srečo le ne dosegajo takšnih razmerij. Pomembno pa je, da se teh vplivov zavedamo.

${ }^{11}$ Lauren B. Resnick, From aptitude to effort: A new foundation for our schools, Deadalus 124/4 (1995), 55-62.

${ }^{12}$ R. N Caine, G. Caine, n. d. 


\section{Človekove pravice in otrokove pravice kot osnova pristopov v vzgoji in izobraževanju}

Na področju razvoja vrednot in pravnih standardov opredeljujemo sodobno razvito družbo kot postmoderno družbo. Zanjo pa je značilno, da prerašča poenotenost $\mathrm{v}$ načinih razmišljanja, $\mathrm{v}$ verovanju in $\mathrm{v}$ vrednotenju ter poudarja temeljne človekove pravice pa tudi otrokove pravice. Prav vidik pravic postopno predstavlja enega od temeljev pri oblikovanju vzgojnoizobraževalnih pristopov, $\mathrm{v}$ nasprotju z doslej prvenstveno upoštevanim vidikom potreb. Med obema pristopoma obstaja kar precejšnja razlika, ki se kaže predvsem v nivoju obveznosti družbe do otrok. Johnsson ${ }^{13}$ je to primerjavo podrobneje prikazal na nivoju razlik v pogledu na zgodnje otroštvo (od rojstva do 8. leta starosti).

\begin{tabular}{|l|l|}
\hline \multicolumn{1}{|c|}{ Zorni kot potreb } & \multicolumn{1}{c|}{ Zorni kot pravice } \\
\hline Otrok je pasiven uporabnik. & Otrok je aktiven uporabnik. \\
\hline $\begin{array}{l}\text { Potrebe se nanašajo na cilje, tudi delne cilje, } \\
\text { kot npr. da naj bo vključenih 90\% deklic. }\end{array}$ & Pravice se nanašajo na vse otroke. \\
\hline Potrebe se lahko zadovoljijo brez podpore. & Pravice se morajo zadovoljiti s podporo. \\
\hline Potrebe lahko hierarhično razvrstimo. & Pravice ni mogoče hierarhično organizirati. \\
\hline Potrebe ne vsebujejo nujno tudi dolžnosti. & Pravice vsebujejo tudi dolžnosti. \\
\hline Potrebe so povezane z obljubami. & Pravice so povezane z obveznostmi. \\
\hline $\begin{array}{l}\text { Potrebe se v različnih kulturah in okoljih } \\
\text { lahko razlikujejo. }\end{array}$ & Pravice so univerzalne. \\
\hline $\begin{array}{l}\text { Potrebe lahko zadovoljimo preko dobrodel- } \\
\text { nosti. }\end{array}$ & Dobrodelnost ni sprejemljiva. \\
\hline $\begin{array}{l}\text { Uresničevanje potreb je pogosto odvisno od } \\
\text { politične volje. }\end{array}$ & $\begin{array}{l}\text { Uresničevanje pravic je odvisno od politične } \\
\text { izbire. }\end{array}$ \\
\hline
\end{tabular}

Preglednica 2: Pogled na zgodnje otroštvo z vidika pravic in potreb. ${ }^{14}$

Ob poudarjanju pristopov $\mathrm{k}$ vzgoji in izobraževanju, ki temeljijo na pravicah, moramo seveda nujno poudariti tudi to, da je na pravice otrok potrebno gledati tudi z vidika odgovornosti in obveznosti, ki jih prinašajo pravice. Zanemarjanje drugega pola teh procesov nujno pripelje do anomalij na izvedbenem nivoju. Uravnovešenje teh procesov pa pomeni iskanje takšnih organizacijskih, vsebinskih in procesnih rešitev, ki zagotavlja-

\footnotetext{
${ }^{13}$ U. Johnsson, A Rights Compared to a Needs Perspective on ECCD, UNICEF 1998.

${ }^{14}$ U. Johnsson, n. d.
} 
jo upoštevanje pravic ob hkratnem oblikovanju odgovornosti udeležencev v procesu.

Premik pristopov $\mathrm{k}$ vzgoji in izobraževanju od tistih, ki temeljijo na potrebah, $\mathrm{k}$ tistim, ki temeljijo na pravicah, je bil izzvan $\mathrm{z}$ vse večjim poudarjanjem vrednot otroštva. Povečala se je odgovornost odraslih za zagotavljanje pogojev, ki pozitivno vplivajo na otrokov razvoj; izoblikovali so se zakoni, ki ščitijo otroka in mu tako zagotavljajo zdravje, nego in spoštovanje njegovih pravic. Zaradi vsega tega se je kakovost življenja otrok močno spremenila.

Seveda pa ta spoznanja veljajo le za manjšinski del svetovne populacije, medtem ko se večinski, revnejši, gospodarsko manj razviti del planeta še vedno srečuje z najosnovnejšimi problemi preživetja. Pri tem pa je razkorak med manjšinskim in večinskim delom planeta Zemlja vse večji, kar postaja tudi z vidika prihodnosti življenja na njem vse bolj zaskrbljujoče in zahteva spremembe v načinih razmišljanja in delovanja in prav zato so osveščanje o pravicah vseh otrok in na njih temelječi pristopi k vzgoji in izobraževanju v sodobnosti v ospredju konceptualnih zasnov vzgoje in izobraževanja vseh, ki se teh razsežnosti zavedajo.

\section{Demokratizacija družbe in njen vpliv na vzgojo in izobraževanje}

Konec prejšnjega stoletja so zaznamovale tudi številne politične spremembe v smeri demokratizacije, ki so prav tako vplivale na spreminjanje tradicionalnih institucij. Tako rekoč hkrati sta v Evropi potekala dva procesa, na eni strani osamosvajanje držav in na drugi strani težnja po združevanju. Vzhodni blok Evrope nekako simbolično ob padcu berlinskega zidu razpade. Razpade tudi takratna Jugoslavija vendar žal v krvavih spopadih, ki so zahtevali ogromno žrtev. Države v Zahodni Evropi pa težijo k oblikovanju vizije Združene Evrope. Vse to pa nakazuje velike spremembe tako na socialnem kot tudi ekonomskem nivoju, kar vpliva na sedanje in tudi prihodnje generacije otrok in odraslih.

$\mathrm{Ob}$ tem ne gre prezreti tudi perečih problemov brezposelnosti. Po mnenju nekaterih avtorjev ${ }^{15}$ je bil v Evropski uniji leta 1998 kar vsak deseti delavec brez dela; ta delež pa je v državah v tranziciji še mnogo večji. Posledica tega je podaljševanje šolanja, da bi se povpraševanje po zaposlovanju zmanjšalo. Podaljšanje šolanja pa za sabo potegne spremembe v strukturi družine. Mladi se vse kasneje odločajo za lastno družinsko življenje; starost

${ }^{15}$ Theodor Sander, Trendi in problemi izobraževalne politike Evropske unije, Sodobna pedagogika 52 (2001), 4, 10-27. 
mater ob prvem otroku je vse višja, nataliteta pa upada. Hkrati s tem se zaradi boljših razmer in zdravstvenega varstva podaljšuje življenjska doba in zmanjšuje umrljivost.

Seveda pa družbenih sprememb v zahodnem svetu in državah v tranziciji tudi ne gre enačiti. Medtem ko se v Zahodni Evropi srečujemo z razvojnim procesom, pa v državah v tranziciji srečamo izrazit preskok, za katerega je značilen razpad povezanosti ideologije in trganje družbenih vezi, ${ }^{16} \mathrm{kar}$ ima posledice tudi za reformiranje šolstva. Pranckuniene, Vildžiuniene in Walshova menijo, ${ }^{17}$ da prehod iz državne kontrole na neodvisnost zahteva velike spremembe v razumevanju in načinu življenja. Te spremembe prinašajo moralno, socialno in ekonomsko krizo. Prav vzgoja in izobraževanje naj bi posamezniku pomagala oblikovati potrebne spretnosti za življenje $\mathrm{v}$ svobodni družbi, kot so: odgovornost, aktivnostim, prilagodljivost na dinamične spremembe.

Dezintegracija družbe je naslednja značilnost držav v tranziciji. Prinaša napetosti na nivoju družbe, kulture in politike z razslojevanjem, ki je določeno z lastnino, socialnim in političnim statusom. Razlike med sloji se večajo in pri tem se hitro veča najrevnejši sloj. Sistem vzgoje in izobraževanja pa ne zmore zagotavljati enakih pogojev za vse. Temu izzivu se lahko postavimo ob bok le, če bo politika na področju šolstva zagotavljala pravičen dostop do kvalitetne vzgoje in izobraževanja za ogrožene posameznike ali skupine in razvijala sposobnosti živeti skupaj ter vplivati na solidarnost v skupnosti.

$\mathrm{V}$ procesu izginjanja enotne ideologije ter reformiranja šolstva stopa $\mathrm{v}$ ospredje tudi vprašanje kakovosti njenega delovanja. ${ }^{18}$ Vse bolj se poudarja potreba po visokih izobrazbenih standardih za vse in združljivosti šolskih sistemov. Ne glede na to, kako ta pojem razumemo, po Štrajnovem mnenju »zadeva cel spekter vsega, kar šola v družbi sploh počne «. ${ }^{19}$

\footnotetext{
${ }^{16}$ Darko Štrajn, Družbene spremembe in izobraževanje, Ljubljana 1998.

${ }^{17}$ Egle Pranckuniene, Marina Vildžiuniene, Kate Burke Walsh, Step by Step to School Improvement, Workshop materials, ISSA 2002.

${ }^{18}$ D. Štrajn, n. d.

${ }^{19}$ D. Štrajn, n. d., 38.
} 



\section{Spremembe \\ znanstvenih \\ paradigem}

$\bigcup^{p}$

premembe na področju vzgoje in izobraževanja pa niso le posledica družbenih, političnih ali ekonomskih sprememb. Gre tudi za spremembe strokovnih pogledov in znanstvenih paradigem, ki včasih sledijo globalnim družbenim spremembam, včasih pa le-te prehitevajo in napovedujejo družbene spremembe. 'Štirideset vrhunskih znanstvenikov, raziskovalcev, inovatorjev in politikov na področju vzgoje in izobraževanja iz desetih držav je leta 1996 (The 21 $1^{\text {st }}$ Century Learning Initiative, 1997) sintetiziralo spoznanja na področju narave človeškega razvoja in učenja ter njihovega vpliva na izobraževanje ter razvoj. V tem okviru so izpostavili štiri pomembna spoznanja:

1) Kriza percepcije: sedanje pojmovanje znanja in učenja kaže prehod od znanosti, ki analizira ločene dele, opazne povezave med dražljaji in odgovori ter posameznikovo notranjo konstrukcijo znanja $\mathrm{k}$ znanosti organiziranja principov, dinamike in interaktivnih odnosov, tj. h konstruiranju znanja, pomena in povezav v zunanjih socialnih skupinah. Gre torej za prehod od behaviorizma h konstruktivizmu. Ta prehod je pogojen z vse večjo integracijo različnih disciplin (kognitivnih znanosti, biologije, antropologije in sociologije), ki so se doslej razvijale ločeno.

2) Novo razumevanje človeka: nove raziskave definirajo sorazvoj človeka v njegovem okolju oziroma interakcijo biološke in kulturne evolucije ter razvoj mnogovrstnih oblik inteligence, kar pomaga dojeti okolje na različne načine.

${ }^{1}$ Slavko Gaber, Beli knjigi na pot, v: Bela knjiga o vzgoji in izobraževanju v Republiki Sloveniji, Ljubljana 1995. 
3) Novo razumevanje delovanja možganov: tradicionalno so se s problematiko učenja ukvarjali predvsem filozofi, psihologi in pedagogi. Ko so se temu krogu pridružili nevrologi, ki z različnimi metodami že lahko opazujejo določene vzorce aktivnosti v možganih, je prišlo tudi do novih spoznanj o tem, kako se individualno učenje v resnici dogaja. To pa zahteva ponovni pregled prejšnjih predvidevanj o tem, kako se učenje dogaja. Ponovno lahko ugotovimo, da je integracija različnih disciplin pospešila vedenje o učenju.

4) Razvijanje idej o učenju: proces učenja je od preproste samoorganizacije prešel $\mathrm{k}$ sodelovalni, medosebni aktivnosti reševanja socialnih problemov, ki je odvisen od pogovora, smiselnega vključevanja izkušenj iz resničnega življenja ter njihove uporabe. Tako učenje in šolanje nista več sinonima. Učenje je posledica izkušenj in mišljenja in sestavni del življenja v celoti. Te ugotovitve predstavljajo spremembe pogledov na učenje od mehaničnega $k$ vse bolj holističnemu pojmovanju. ${ }^{2}$

Vse to pa seveda opozarja na potrebo, da je bilo potrebno osnovne predpostavke, na katerih temeljita tradicionalna vzgoja in izobraževanje, postaviti pod vprašaj in jih oceniti $z$ vidika potreb ljudi v 21 . stoletju.

${ }^{2}$ Fritjof Capra, The Turning Point: Science, Society, and the Rising Culture, New York 1982. 


\section{Predšolska vzgoja \\ $v$ izzivih sodobne \\ družbe - obdobje \\ zrelosti ali obdobje \\ utrditve}

adnjih dvajset, še bolj pa zadnjih deset let se na področju organi-

zirane predšolske vzgoje srečujemo s ponovnim razcvetom. V tem obdobju se je področje dokončno uveljavilo in hkrati dozorelo. V veliki meri te spremembe lahko pripišemo spremembam v družbi, ki so tako kot ostala področja vzgoje in izobraževanja močno zaznamovale tudi predšolsko. Ker smo že v prejšnjem poglavju namenili pozornost družbenim izzivom in njihovim vplivom na vzgojo in izobraževanje, naj na tem mestu samo opozorimo, da se z vsemi opisanimi problemi srečuje tudi organizirana predšolska vzgoja. V nadaljevanju bomo pozornost namenili pedagoškim idejam in pristopom, ki so v tem obdobju dozoreli. Pozornost bomo namenili tudi novim znanstvenim podmenam, ki usmerjajo sodobno organizirano predšolsko vzgojo ter vse večji osveščenosti in zagovorništvu otrok. Še pred tem pa je potrebno poudariti tudi to, da se s procesom sprememb sooča tudi otrok, ki mora osvojiti vse bolj kompleksne nivoje gibanja, mišljenja, čutenja, biti v interakciji z ljudmi in objekti v tem spremenjenem in hitro spreminjajočem se svetu.

Pojav hitrih sprememb je še kako prisoten tudi na področju predšolske vzgoje. Znižanje umrljivosti otrok, primernejša prehrana in nega otrok, skrb za zdravje mater in otrok, poudarjanje otrokovih pravic, spremenjena vloga žensk v družbi, spremembe v družini, spremembe v proizvodnji, ekonomiji in trženju, hiter tehnološki razvoj, politične spremembe, spremenjeni cilji vzgoje in izobraževanja ipd. zahtevajo tudi od organizirane predšolske vzgoje, da se na njih odziva. Programi na področju organizirane predšolske vzgoje so v bistvu del procesa spreminjanja. V zadnjih petintridese- 
tih do štiridesetih letih so ti programi doživljali eksplozijo v razvoju. Čeprav so služili različnim namenom, kot so npr. varstvo otrok v času odsotnosti staršev zaradi zaposlitve, predšolsko izobraževanje kot kompenzacija za primanjkljaje iz okolja, okrepljena skrb za prehrano in nego otrok, so bili hkrati usmerjeni predvsem na spodbujanje otrokovega razvoja ali pa na podpiranje družin in skupnosti pri doseganju ciljev. Seveda so ti pogledi obremenjeni s pogledi, vrednotami, znanjem in tehnologijo, ki je značilna za razviti svet in zato ne morejo biti univerzalni. ${ }^{1}$

\section{Novi cilji}

Vse večja potreba po odpiranju zaprtih struktur industrijskega modela vzgoje in izobraževanja se je pokazala tudi na področju organizirane predšolske vzgoje. Ideal vzgojno-izobraževalne institucije se je od tekočega tra$\mathrm{ku} \mathrm{v}$ tovarni premaknil $\mathrm{k}$ ateljeju ali raziskovalnemu laboratoriju, kjer vsi udeleženci (otroci in vzgojitelji, pogosto pa tudi člani družin ter ljudje iz neposrednega okolja) ustvarjajo, raziskujejo in se učijo.

Med cilji tako ni v ospredju le razvijanje intelektualnih zmožnosti, ampak predvsem:

- razvijanje sposobnosti reševanja problemov,

- spoprijemanje s problemi,

- odkrivanje pomena stvari,

- iskanje in predstavljanje ter uresničevanje možnih in želenih alternativ,

- odkrivanje in organiziranje misli,

- razmišljanje in sporočanje svojih misli in čustev,

- osveščanje o sebi, drugih in okolju,

- pripravljenost in aktivna naravnanost k spreminjanju obstoječega,

- skrb zase in za druge, pomoč drugim,

- uresničevanje želja,

- sodelovalnost ipd.

Te sposobnosti so pomembne zato, da se bo posameznik spoprijel in reševal probleme $\mathrm{v}$ stalno spreminjajočih se pogojih življenja, zato se jim je prilagajala tudi organizirana predšolska vzgoja, ki postaja bolj bogata, fleksibilna, bolj odprta. Otroku naj bi nudila potrebno svobodo za rabo nje-

${ }^{1}$ Martin Woodhead, In search of the rainbow. Pathways to quality in large-scale programs for young disadvantage children. Early Childhood Development, Practice and Reflections 10, Hague 1996. 
govih individualnih strategij mišljenja, osebnih stališčc, mnenj in prepričanj ter čutenje $\mathrm{v}$ procesu konstruiranja znanja ter spoznavanja pojmov pa tudi pri spoprijemanju s problemi. Otrokom naj bi nudila potrebno spodbudo, da svoje porajajoče zmožnosti uporabljajo čim bolj pogosto, na čim bolj samosvoj in domišljijski način. Ustvarjala naj bi situacije ali pa izkoristila spontane situacije oziroma »pobude trenutka«, v katerih lahko otroci dajejo svoje ideje, inicirajo dejavnost, povedo svoje mnenje in občutja. Ob tem pa ne smemo pozabiti na ustvarjanje možnosti za pridobivanje izkušenj neposredne odgovornosti za svoje ideje in ravnanje. Končno pa naj bi otroku omogočili presojanje ter možnosti, da to, česar so se naučili, uporabljajo pri novih nalogah in v novih situacijah. Skratka, tudi organizirana predšolska vzgoja je v novih, spreminjajočih časih izoblikovala nove cilje, ki se odzivajo na spremembe v družbi.

\section{Otrokove pravice in potrebe ter zagovorništvo}

Zanesljivo lahko trdimo, da so raziskovalne ugotovitve o učinkih predšolske vzgoje na otrokov razvoj vplivale na pojav intenzivnega zagovorništva vseh otrok, ki temelji na Konvenciji o otrokovih pravicah. Lahko pa seveda trdimo tudi obratno, da je k novemu razmišljanju o otrocih in organizirani predšolski vzgoji prispevalo širjenje zagovorništva otrok, ki je bilo v tem obdobju izrazito intenzivno. Zagovorništvo na področju predšolske vzgoje ni nov pojav. Načeloma lahko to funkcijo pripišemo vsem pionirjem, ki so v preteklosti zagovarjali interese otrok. Zgodovinsko gledano je bilo včasih zagovorništvo predvsem v domeni posameznikov, danes pa je bolj množično in z demokratizacijo družbe, dostopom do informacij ter osveščenostjo državljanov tudi bolj prisotno na različnih ravneh od mednarodne do povsem lokalne ravni. Zagovorništvo postaja tem bolj pomembno in tudi učinkovito, čim bolj se zavedamo, da tvorijo osnovo organizirane predšolske vzgoje otrokove pravice in ne le potrebe otrok oziroma njihovih staršev. Načeloma zagovorništvo na lokalni ravni zajema :

- zavzemanje za reševanje problemov, ki zadevajo otroke in družine,

- širjenje znanja in izkušenj,

- ojačanje staršev in družine,

- zavzemanje za stroko in tiste, ki v stroki delajo.

$\mathrm{Na}$ lokalni ravni je zagovorništvo v tem obdobju pridobilo veljavo tudi zaradi vse bolj poudarjene potrebe po odpiranju institucij v okolje ter vključevanju lokalne skupnosti v odločanje in vodenje institucij. Po drugi strani 
pa je tudi višja stopnja ozaveščenosti državljanov povzročila vse jasnejše in glasnejše zahteve po kvalitetnem življenju otrok.

$\mathrm{Na}$ mednarodnem nivoju so $\mathrm{k}$ spreminjanju gledanja na otroka prispevala predvsem prizadevanja za upoštevanje otrokovih pravic, ki so nastala na osnovi Konvencije o otrokovih pravicah (1989), Deklaracije Svetovne konference o izobraževanju za vse (1990), Svetovne konference o otrocih (1990) ipd. Zahteve in ugotovitve, ki so nastale na tem nivoju, pa lahko strnemo takole:

1) Vsi otroci, ne glede na razlike v spolu, rasi, jeziku, religiji ali drugem, morajo imeti možnosti za razvijanje vseh svojih potencialov.

2) Otroci zaradi svoje fizične in mentalne ranljivosti potrebujejo posebno skrb in varovanje.

3) Otroci, ki živijo v posebej težkih razmerah, potrebujejo posebno pozornost.

4) Starši in družine (ne glede na to, kako jih definiramo), moški in ženske, imajo kot svojo primarno obveznost skrb za nego, vzgojo in razvoj ter izobraževanje svojih otrok.

5) Vlade morajo ustanoviti politiko takšnega okolja, ki bo omogočalo družinam in skupnosti zadovoljiti svoje obveznosti do nege, skrbi, varovanja in izobraževanja otrok.

Konvencija o otrokovih pravicah predstavlja okvir za vse akterje, ki delujejo v korist otrok. V enem samem dokumentu opredeljuje civilne, politične, ekonomske in kulturne pravice in velja za vse otroke $\mathrm{v}$ vseh situacijah, zato ima univerzalen značaj. Dokument temelji na naslednjih principih: ${ }^{2}$

- Nediskriminitavnost: kar pomeni, da pravice zadevajo vse otroke. Otroci, ki so marginalizirani ali izločeni, ne morejo biti izpuščeni iz oblikovanja programov in politik. Problematika izključenosti, neenakosti in nepravičnosti tako postane osrednja skrb pri oblikovanju programov in politik na področju predšolske vzgoje. Vsi otroci imajo torej pravico za razvijanje svojih potencialov ne glede na razlike v rasi, barvi, spolu, jeziku, mnenju, izvoru, zmožnostih ali katerikoli drugi značilnosti. Nekateri pa pri tem potrebujejo več pozornosti in asistence, da bi jim tako omogočili enakost možnosti.

- Otrokov (najboljši) interes: to, kar je za otroka najboljše, naj bi bilo prvo merilo vseh akcij in odločitev na vseh področjih delovanja, namenjene-

${ }^{2}$ Judith Evans, Arguments in Support of Investment in Early Childhood, Materials for Global Leaders Group, 2008 
ga otrokom. Ta princip podpira na otroka osredinjene pristope in osredinjenje na iskanja najboljših rešitev za otroka v primeru akcij, ki jih izvajajo javne ali privatne institucije in udeleženci znotraj družine. Princip je obenem tudi osnova za evalvacijo tako zakonskih usmeritev kot neposredne prakse.

- Pravica do življenja, preživetja in razvoja: ta princip zadeva otrokov razvoj, ki ga pojmuje holistično. Koncept holističnega pristopa pomeni upoštevanje otrokovega fizičnega, mentalnega, moralnega, socialnega in spiritualnega razvoja. Princip je povezan tudi s pravico do dostopnosti socialnih servisov in potrjevanja akcij za otroke, ki to bolj potrebujejo. Princip zavezuje države podpisnice, da ukrepajo in vsem otrokom omogočijo dostop do osnovnih servisov oziroma ukrepov na tem področju.

- Spoštovanje in upoštevanje otrokovega pogleda: otroci naj bi imeli možnost participirati v odločitvah, ki nanje učinkujejo na način, ki je primeren njihovi starosti in njihovim nastajajočim potencialom. Ta princip je močno povezan s principom, ki zahteva najboljši interes za otroka, saj poudarja pomen otrokovih mnenj v realizaciji njihovih pravic. Poseben izziv pri tem predstavlja zagotavljanje resnične participacije otrok iz marginaliziranih skupin ali revnih družin oz. otrok, ki živijo v težkih pogojih. Princip uveljavlja pravico otrok, da jih slišimo in poziva $\mathrm{k}$ posebni pozornosti pri zagotavljanju pristnega vključevanja tistih iz neugodnih razmer.

Pravice otroka so na področje pedagogike prinesle novo pojmovanje otroka in otroštva. Otrok ni več nekdo, ki potrebuje podporo, ampak nekdo, ki ima pravico do te podpore. Naša dolžnost pa je, da mu to pravico pomagamo realizirati. Sprememba gledanja na otroka je prinesla tudi veliko sprememb v načinih delovanja nacionalnih politik in mednarodnih organizacij, da te pravice zagotovijo. Če pogledamo primer gledanja na isto vprašanje $s$ pozicije potreb in $s$ pozicije pravic, bo morda preobrat $\mathrm{v}$ razumevanju bolj razumljiv. Iz pozicije potreb bomo rekli: 80 odstotkov vseh otrok je cepljenih. Če pa govorimo iz pozicije otrokovih pravic pa bomo rekli: 20 odstotkov otrok pravice do cepljenja ni realiziralo.

Otrokove pravice torej postavljajo otroka v center pozornosti. Programi, namenjeni otrokom, tako temeljijo na poznavanju in razumevanju človekovih pravic in pogojev, v katerih so otroci. Analiza in ocena situacij, v katerih so otroci, s perspektive pravic vodi v razumevanje mešanice razlogov, ki skupaj onemogočajo otroku uživati njegove pravice. Programi, ki temeljijo na otrokovih pravicah, zahtevajo široko množico zanesljivih par- 
tnerstev in zaveznikov otrok. Usmerjeni pa so tudi k trajnim rezultatom za otroke.

Prav oblikovanje Konvencije o otrokovih pravicah, stališč, priporočil in drugih dokumentov, ki so iz tega dokumenta izpeljani, je postalo gibalo mednarodnega sodelovanja in prizadevanj za okrepitev regionalnih zmožnosti za spodbujanje programov na področju predšolske vzgoje.

Gledano z vidika svetovnega položaja otrok vemo, da se razlike med bogatimi in revnimi neprestano povečujejo in da revni predstavljajo več kot dve tretjini svetovne populacije. Zato se na eni strani nerazviti del svetovne populacije ubada predvsem $s$ podpiranjem programov, ki omogočajo preživetje. Šele zadnje desetletje pa je tudi na tem področju prineslo tudi v nerazvite države izobraževalne programe, ki so namenjeni predšolskim otrokom. Pri tem je poglavitna naloga teh programov, ki se izvajajo v raznolikih kulturah, poiskati ustrezne strategije za uresničevanje kakšnihkoli oblik združevanja otrok, v katerih lahko obogatimo njihove izkušnje in priložnosti za učenje. Največkrat gre v teh primerih za predšolske programe, ki jih izvajajo po domovih (home-based program), pri tem pa so načini izvedbe zelo različni. Tudi različni programi, ki jih izvajajo različne strokovne ali laične organizacije v lokalni skupnosti (community based program), so vse bolj priljubljen način nudenja možnosti za učenje predšolskim otrokom.

Ker v nekaterih kulturah nekatere od zahtev, ki temeljijo na konvenciji o otrokovih pravicah in drugih mednarodnih dokumentih, prihajajo v nasprotje s prepričanji, vrednotami in ustaljeno tradicionalno prakso, obstaja seveda tudi možnost, da s programi, ki so namenjeni skrbi in izobraževanju predšolskih otrok, spreminjamo vrednote lokalne kulture. Tako je npr. v nekaterih kulturah povsem neprimerno, da se v izobraževanje vključujejo deklice, čeprav jim ta pravica po mednarodnih deklaracijah pripada. Ker pa je varovanje otrokovih pravic za vlade obvezujoče, lahko svojo zagovorniško vlogo v tem primeru odigrajo najrazličnejše laične ali strokovne organizacije, posamezniki ipd., ki s pritiskom na vlade postopno spreminjajo tradicionalne poglede, zasidrane v kulturi, ki so škodljive za otroke. $\mathrm{Ne}$ gre torej prezreti, da pojem kulture ni statičen, ampak se pod vplivom sprememb v družbi tudi spreminja.

Eden od problemov, s katerimi se ukvarja razviti svet, pa je tudi zagotavljanje enakih možnosti znotraj razvitega dela sveta, saj se tudi v tem primeru srečujemo z vse večjimi razlikami med bogatimi in revnimi. Prav krepitev možnosti za učenje in razvoj v predšolskem obdobju je ena od poti, 
ki lahko ustvari enake možnosti tudi za otroke ogroženih skupin prebivalstva (revni, socialno-ekonomsko ogroženi, otroci s posebnimi potrebami, pripadniki manjšin, ipd.).

$\mathrm{Na}$ te probleme je skušala vplivati tudi Komisija Združenih narodov za otrokove pravice in leta 2006 izdala dokument $\mathrm{z}$ naslovom »Izvajanje otrokovih pravic v zgodnjem otroštvu « (UN CRC/C/GC/Rev. 1, 2006) z naslednjimi zahtevami do podpisnic Deklaracije o otrokovih pravicah:

- Da se obvezujejo izboljševati položaj otrok z ustreznimi politikami, investicijami $\mathrm{v}$ predšolske programe in infrastrukturo, $\mathrm{z}$ raziskovanjem in zbiranjem podatkov, z usposabljanjem o pravicah v predšolskem obdobju;

- Da se posvečajo vsem otrokom in pri tem dajejo posebno pozornost tistim, ki najbolj potrebujejo posebno pozornost. Programi za posebej ogrožene otroke naj pri tem zadevajo programe za urejanje različnih vidikov njihovega življenja (vzgoja, nega, zdravje, prehrana, bivališče) ter pri tem zagotovijo standarde življenja in socialne varnosti za otrokov fizični, mentalni, spiritualni, moralni in socialni razvoj;

- Da spoznajo, da so otroci nosilci vseh pravic, ki so zapisane v Deklaraciji o otrokovih pravicah, vključno s pravico do izobraževanja. Pri tem sedanja stopnja zagotavljanja organizirane predšolske vzgoje za dojenčke in malčke že predstavlja odstopanje $\mathrm{v}$ primerjavi s programi, ki so jih deležni otroci od tretjega leta do vstopa v šolo;

- Da oblikujejo visoko kvalitetne, razvojno primerne in kulturno relevantne programe $\mathrm{v}$ sodelovanju z lokalnimi skupnostmi.

- Da vodijo politiko in prakso zagotavljanja otrokovih pravic v soglasju z osnovnimi značilnostmi razvoja in vzgoje otrok, in sicer:

- Da mali otroci oblikujejo močno čustveno navezanost na svoje starše oziroma pomembne odrasle;

- Da so starši prvi in najpomembnejši vzgojitelji svojih otrok, kar zavezuje vlade, da staršem nudijo ustrezno podporo in oblikujejo takšne programe, ki vključujejo starše in z njimi razvijajo partnerstva;

- Da mali otroci oblikujejo pomen in smisel fizične, socialne in kulturne dimenzije sveta, $\mathrm{v}$ katerem se nahajajo in se s svojo aktivnostjo in interakcijo z drugimi otroki in odraslimi postopno učijo. Zato je potrebno interpretirati pravico do izobraževanja $\mathrm{v}$ predšolskem obdobju kot pravico, ki se začne z otrokovim rojstvom; 
- Da je cilj izobraževanja omogočiti otroku razvoj njegovih spretnosti, učenja in drugih kompetenc, človeškega dostojanstva, dobrega mnenja o sebi in samozaupanja. To pa lahko dosežemo s pristopi, osredinjenimi na otroka, ki odsevajo naravno dostojanstvo do otroka. Programi za male otroke naj temeljijo na standardih kakovosti v odnosu do zdravja, varnosti, usposobljenosti vzgojiteljev;

- Da se vsi štirje osnovni principi, na katerih temelji Konvencija o otrokovih pravicah, nanašajo na vse otroke.

Vtesnipovezavis pravicamiavtorjitudiv tem obdobju poudarjajoosnovne potrebe otrok. Človeška bitja ostajajo nemočna veliko dlje kot vsa ostala živa bitja in zato zahtevajo velik vložek ljubezni, skrbi in pozornosti s strani družine, pedagogov in drugih strokovnjakov pa tudi skupnosti, v kateri živijo.

Vsako razmišljanje o vzgoji otrok se mora začeti tudi z upoštevanjem otrokovih osnovnih potreb kot človeških bitij. Otroci imajo pravico do skrbnih odnosov, zaslužijo si odrasle, ki si vzamejo čas, poslušajo njihove skrbi, podpirajo njihova prizadevanja, jih obravnavajo $\mathrm{z}$ dostojanstvom in jih varujejo pred poškodbami. Vsi otroci imajo enake osnovne fizične, socialne in emocionalne ter kognitivne potrebe, ki prispevajo $\mathrm{k}$ njihovemu zdravju, dobremu počutju, uspehu in razvoju. ${ }^{3}$ Minimalne fizične potrebe vključujejo hrano, pijačo, obleko, streho nad glavo in zdravje. Osnovne socialne in emocionalne potrebe pa vključujejo dosledne in predvidljive odnose s skrbnim odraslim, sprejetost pri vrstnikih, nenasilje in nediskriminacijo. Končno pa ima vsak otrok tudi minimalne kognitivne potrebe, ki jih Isenbergova opredeljuje kot $\gg$ Zmožnost, da izraža misli in čustva, da procesira informacije na smiseln način, da je vpet v ustvarjalno reševanje problemov in da doživlja uspeh, tako doma kot v instituciji oziroma v skupnosti $\ll{ }^{4}$

Jalongo in Isenbergova menita, ${ }^{5}$ da na to, kakšen bo otrok, močno vpliva to, kako uspešno starši in pedagogi uresničujejo naslednje potrebe otrok:

1) Potreba po varnosti. Otroci morajo imeti občutek varnosti. Njihov svet mora biti predvidljiv, zato je pomembno, da ima otrok vsaj eno odraslo

\footnotetext{
${ }^{3}$ Erik H. Erikson, Childhood and Society, New York 1963; A. H. Maslow, Motivation and personality, New York 1954; Richard Weissbourd, The myth of vulnerable child, Reading, Massachusetts 1996.

${ }^{4} \mathrm{~J}$. P. Isenberg, Development issues affecting children, v: J. P. Isenberg, M. R. Jalongo (eds), Major trends and issues in early childhood education: Challenges, controversies, and insights, New York 1997, 30 .

${ }^{5}$ M. R. Jalongo, J. P. Isenberg, Exploring Your Role - A Practitioner's Introduction to Early Childhood Education, Merrill 2000, 73.
} 
osebo, na katero se lahko zanese in ki skrbi zanj. Občutek varnosti vpliva na njihovo zmožnost sprejemati tveganje, na zmožnost raziskovati in oblikovati pozitivno mnenje o sebi. ${ }^{6}$

2) Potreba po ljubezni. Otroci vseh starosti potrebujejo ljubezen in naklonjenost pomembnih odraslih, da bi uspešno rasli in se čutili podprti.

3) Potreba po razumevanju in sprejemanju. Vsi otroci potrebujejo odraslega v svojem življenju, ki jih bo brezpogojno razumel, sprejemal in podpiral njihovo individualnost skozi življenje.

4) Potreba po kompetentnosti, odgovornosti in neodvisnosti. Od zgodnjih let naprej se mora otrok naučiti, da postaja vse bolj sposoben in odgovoren zase in za svoje lastne dejavnosti.

5) Potreba po uspehu. Skupaj s potrebo po kompetentnosti nastaja tudi potreba po uspehu. Če so otroci uspešni v tem, kar počno, se jim oblikujejo samospoštovanje, zaupanje in motivacija za učenje.

6) Potreba po svetovanju. Vsi otroci potrebujejo primerne omejitve, ki so primerne za njihov nivo razvoja in jim omogočajo ohraniti njihovo dostojanstvo in samospoštovanje.

7) Potreba po upoštevanju in spoštovanju. Če želimo, da bo otrok spoštoval druge, mora sam biti spoštovan od odraslih, ki skrbijo zanj.

$\mathrm{Charney}^{7}$ pa je povzel pravice in potrebe otrok z vidika tega, kaj si oni želijo v organiziranih oblikah vzgoje in izobraževanja, in meni, da si otroci želijo:

- biti vsak dan toplo sprejeti,

- biti upoštevani in cenjeni,

- imeti možnost izbirati,

- se zabavati in uživati v vrtcu ali šoli,

- da jih odrasli in otroci slišijo in jim odgovarjajo,

- imeti možnost, da se pogovarjajo s prijatelji,

- pridobivati zmožnosti, spretnosti in zaupanje,

- da tudi drugi vedo, da imajo določene sposobnosti,

- da tudi drugi vedo, da znajo misliti in reševati probleme,

- spoznavati svet,

${ }^{6}$ S. Bredekamp, C. Copple, Developmentally appropriate practice in early childhood programs (rev. ed.), Washington D. C. 1997.

${ }^{7}$ Ruth Charney, Teaching children to care: Management in the responsive classroom, Greenfield, Massachusetts 1992, 203. 
- vnaprej poznati rutinske dejavnosti tekom dneva in tedna v vrtcu in šoli,

- imeti primerne naloge, ki jih lahko opravijo sami, in se učijo neodvisnosti,

- dajati in prejemati komplimente,

- vzpostavljati tople odnose z odraslimi,

- dobiti podporo od odraslih,

- biti izpostavljeni novim izzivom in tveganju,

- imeti v oddelku poštena pravila,

- da tudi drugi vedo, da so zmožni sprejemati in dati pomoč drugim,

- da tudi drugi vedo, da se učijo reševati spore,

- znati pridobiti in obdržati prijatelje,

- biti prijatelji,

- biti sprejeti v skupnosti vrstnikov in vanjo prispevati,

- imeti možnost, da lahko delajo napake, kršijo pravila ali delujejo napačno in imajo priložnost to kasneje popraviti.

Pravice in potrebe otrok so tako v tem obdobju vsekakor postale eno bistvenih izhodišč za razmišljanje o ciljih, organizaciji in izvajanju organizirane predšolske vzgoje.

\section{Vpliv sodobnih študij o delovanju možganov}

Zanesljivo so eden od odločilnih faktorjev, ki je v tem obdobju vplival na intenzivnejše zanimanje strokovne in politične javnosti za predšolsko obdobje, pa tudi za obdobje na začetku šolanja, sodobne študije o delovanju in razvoju možganov. To, kar so posamezni strokovnjaki le slutili, ko so poudarjali pomen najzgodnejših let za otrokov nadaljnji razvoj, je končno dobilo svojo znanstveno potrjeno osnovo v študijah o delovanju in razvoju možganov ter iz teh ugotovitev izpeljanih spoznanj o načinu učenja predšolskih otrok. Ta spoznanja so ovrgla mehanične pristope $\mathrm{k}$ učenju predšolskih otrok in podprla celostne, holistične in integrirane pristope $\mathrm{k}$ učenju.

Globlje razumevanje možganov so še posebej omogočila znanstvena odkritja nevrologije, ki so odkrila pogled v naravno holistično delovanje možganov, ko ti sintetizirajo učenje iz obeh možganskih hemisfer. Razvoj in obseg spoznanj o delovanju možganov se hitreje širi na področje pedagogike šele v zadnjih desetih letih, vendar je že dodobra spremenil naše domneve o tem, kako poteka učenje. Raziskovanje možganov v zadnjem desetletju poteka s hitrim tempom s pomočjo vse bolj izpopolnjenih naprav za slika- 
nje možganov (nuklearna tomografija), za odkrivanje kemijskih procesov v možganih (spektrometrija) ter postopkov za odkrivanje možganskih valov (magnetoencefalografija) pa tudi z razvojem nanotehnologije, ki omogoča vpogled v najmanjše strukture naših možganov in končno s kliničnimi študijami na živalih in ljudeh. V te študije so se vključile številne znanstvene discipline s področja fizike, kemije, genetike, farmakologije ipd. Najnovejša raziskovanja in ugotovitve o delovanju možganov so in bodo vplivala na vrsto pedagoških odločitev tudi na področju organizirane predšolske vzgoje, kot so npr. začetek šolanja, vključevanje staršev, metode učenja, okolje za učenje, predvsem pa vplivajo na naše gledanje in razumevanje najzgodnejšega razvoja in učenja otrok.

V nadaljevanju prikazujemo povzetek spoznanj, ki smo jih povzeli iz študij o možganih, kot jih predstavljajo nekateri strokovnjaki na tem področju. ${ }^{8}$

1) Osnovne povezave v možganih so vzpostavljene že pred rojstvom otroka. Med nosečnostjo se formira osnovna arhitektura možganov. Različni deli možganov, kot so možgansko deblo, veliki in mali možgani, so že oblikovani, prav tako tudi povezave med različnimi deli možganov. ${ }^{9}$ Novorojenček lahko vidi, vendar še nima razvite zmožnosti jasnega fokusiranja obeh oči na en objekt. Prav tako nima razvitih bolj prefinjenih vizualnih zmožnosti, kot je na primer zaznavanje globine in ne zmore koordinirati oči z rokami. Kontrola vida po drugem tednu življenja pa lahko že pokaže probleme z vidom, ki brez korekcije lahko povzroči, da slabotno oko ali oko, ki ga otrok ne uporablja, zgubi funkcionalno povezavo z možgani. Prav zgodnje vaje vizualnega sistema lahko to onemogočijo. Njegov vid lahko stimuliramo s stvarmi, ki jih gleda. Tudi učenje jezika ima svoje začetke že pred rojstvom. Otrok se v materinem trebuhu obrača proti melodiji glasu svoje matere. Novorojenčkovi možgani pa so že ožičeni za iskanje in učenje jezika. Razvoj možganov pred prvim letom starosti poteka mnogo bolj intenzivno, kot so menili prej. Prvi meseci po rojstvu so izjemno pomembni za dozorevanje možganov. V tem času število sinaps, povezav med nevroni, ki v bistvu omogočajo učenje, naraste dvajsetkrat. Ne smemo pa pozabiti, da možgani nadaljujejo z rastjo tudi kasneje.

${ }^{8}$ Leslie A. Hart, Human brain and human learning, New York 1983; P. Russell, Knjiga o možganih, Ljubljana 1993; R. Shore, Rethinking the Brain: New Insights into Early Development. New York 1997; Eric Jensen, Teaching with the brain in mind, Alexandria, Virginia 1998; Marilee Sprenger, Learning and Memory - The brain in action, Alexandria, Virginia 1999.

9 James Fraser Mustard, Bringing Child Development to Center Stage, CCF Conference 2003. 
2) Človekov razvoj je odvisen od medsebojnih vplivov dednosti in okolja. Večina domnev o odnosu med dednostjo in okoljem je temeljila na stari domnevi, da geni, s katerimi pridemo na svet, odločajo o tem, kako se bodo naši možgani razvijali in obratno - da to, kako se naši možgani razvijajo, določa, kako bomo vzpostavili interakcijo z okoljem. Sodobne raziskave pa kažejo, da so skozi ves proces razvoja (pa celo pred rojstvom) naši možgani pod vplivom okolja (vrste nege, hrane, okolice, dražljajev, ki jih posameznik dobiva). Vpliv okolja tako postaja dramatičen in specifičen, saj ne določa le splošnega razvoja, ampak tudi to, kako bodo zapletene možganske strukture prepletene. $Z$ novim znanjem o tem, kako delujejo možgani, se bo verjetno tudi debata o odnosu med dednostjo in okoljem ter njunem vplivu na razvoj končala. Nova spoznanja dokazujejo, da je to, kako se človek razvija in uči, kritično in kontinuirano odvisno od medsebojnega vplivanja genetskih sposobnosti in okolja. Odločilna sta torej oba faktorja.

3) Kompleksnost mreže ožičenja je odvisna od stalnih in učinkovitih prenosov signalov iz enega dela možganov v drugega. Gradbeni material takšne mreže predstavljajo možganske celice - nevroni ter povezave ali sinapse, ki celice povezujejo z drugimi nevroni. Prav sinapse so odločilnega pomena za razvoj in učenje, saj oblikujejo živčne poti. $V$ trenutku, ko je posameznik v interakciji z okoljem, reagira na dražljaj, sprejme informacijo, jo procesira ali shrani, se po živčnih poteh sproži nov signal, ki ga omogočajo sinapse. $\mathrm{V}$ tem procesu se sinapse aktivirajo.

Največje število povezav med nevroni oziroma sinapsami je v tretjem letu starosti. Do te starosti formacija sinaps izjemno raste, nato pa sledi obdobje platoja, temu pa obdobje rezanja oziroma eliminiranja, ko gostota upada in je primerljiva $\mathrm{z}$ nivojem $\mathrm{v}$ odraslosti. To pomeni, da se prav $\mathrm{v}$ prvih treh letih življenja oblikuje večina sinaps. Njihovo število ostane približno enako vse do okoli desetega leta starosti oziroma se približno dvakrat poveča. 


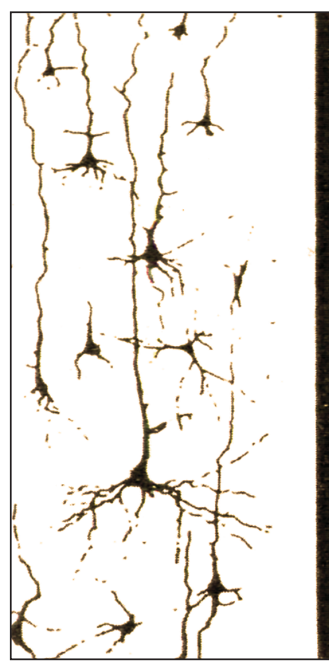

Ob rojstvu

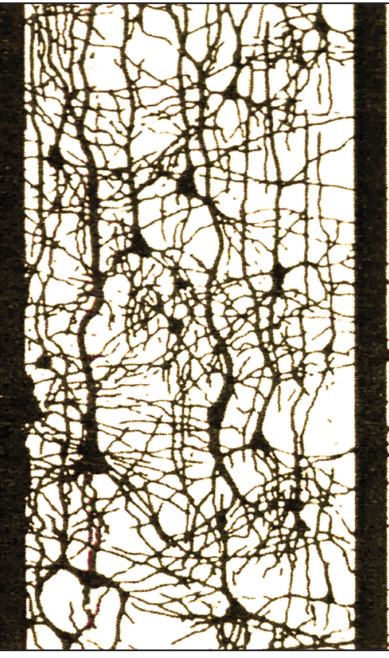

Pri šestih letih

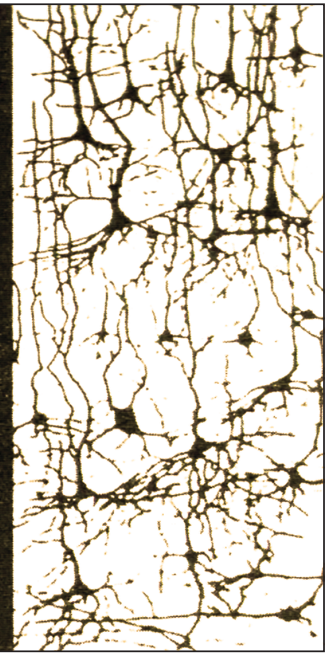

Prištirinajstih letih

Slika 1: Gostota povezav med nevroniv različni starosti. ${ }^{10}$

Slika 1 prikazuje podrobno analizo vzorcev povezav med nevroni od rojstva do štirinajstega leta starosti. Nastala je po delih Huttenlockerja ${ }^{11}$ in kaže povezave med nevroni ob rojstvu, $\mathrm{v}$ šestem letu in $\mathrm{v}$ štirinajstem letu starosti. Gostota povezav pri šestem letu je očitno višja kot ob rojstvu, pa tudi od tiste v štirinajstem letu starosti. Prav tako je gostota ožičenja pri štirinajstem letu večja od tiste ob rojstvu. Primerjava ožičenja v šestem in štirinajstem letu kaže, da so šibke povezave odmrle. Ožičenje nevronov v možganih je močno odvisno od stimulacije in rabe povezav med nevroni. S staranjem bodo poti, ki se ne uporabljajo, intenzivno izumrle. Slika zelo nazorno kaže, kako zgodnje obdobje našega življenja pomembno vpliva na ožičenje in izklesavanje možganov.

Zato so zgodnje izkušnje tako zelo pomembne, saj bodo sinapse, ki so aktivirane večkrat, postale stalne, sinapse, ki pa ne bodo aktivirane, pa se bodo verjetno nagibale $k$ uničenju. Razvoj možganov je tako proces, $v$ katerem ni srednje poti, označujejo ga z rekom »rabi ali izgubi« (»use it or lose it«), kar pomeni, da več ko bo možnosti za pridobivanje zgodnjih izkušenj, bolj bodo možgani oživčeni.

\footnotetext{
${ }^{10}$ Povzeto po: R. Shore, Rethinking the Brain: New Insights into Early Development. New York 1997.

${ }^{11}$ Citirano po: R. Shore, n. d.
} 
4) Čeprav je gostota povezav na najvišjem nivoju v prvih treh letih otrokovega življenja, to ne pomeni, da imajo možgani največjo moč $\mathrm{v}$ tem obdobju, saj se velik del učenja odvija tudi kasneje. Res pa je, da obstajajo tako imenovana kritična obdobja razvoja možganov, ki ga mnogi pojmujejo kot občutljiva obdobja. To je čas v razvoju, ko odsotnost nekaterih stuimulusov povzroča razvojne odklone. Občutljiva obdobja so ponavadi daljša in na nek način dopuščajo več fleksibilnosti. Na sliki 2 je prikazan pregled občutljivih obdobij v zgodnjem življenju z ozirom na razvoj specifičnih sposobnosti. Pri tem so nakazana tudi obdobja, ko kritično obdobje za razvijanje posameznih sposobnosti že upada.

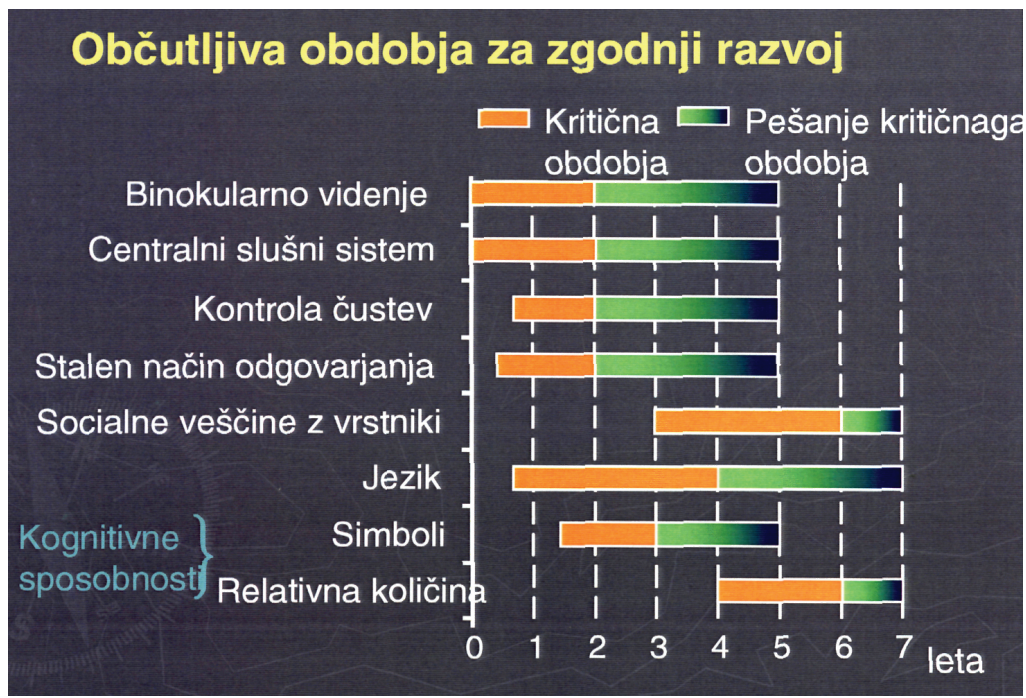

Slika 2: Občutljiva obdobja za zgodnji razvoj. ${ }^{12}$

Ožičenje možganov za različne funkcije je v različnih obdobjih življenja različno. Nelson ${ }^{13}$ je prikazal razvoj človeških možganov glede na formiranje sinaps na področju senzornih poti, jezika in kognicije v prvih šestnajstih letih življenja. Slika 3 kaže, da so senzorne poti razvite pred jezikovni$\mathrm{mi}$, te pa pred kognicijo. Jasno je vidno tudi to, da se te poti in povezave pojavijo v najzgodnejših letih življenja in so odvisne tudi od izkušenj pred roj-

\footnotetext{
${ }^{12}$ Nelson, povzeto po: J. F. Mustard, Bringing Child Development to Center Stage, CCF Conference 2003.

${ }^{13}$ Povzeto po: J. F. Mustard, n. d.
} 
stvom. Še več, problem v razvoju senzornih poti ob rojstvu in takoj po njem bo vplival tudi na razvoj jezika in kognitivni razvoj, ki mu sledita.

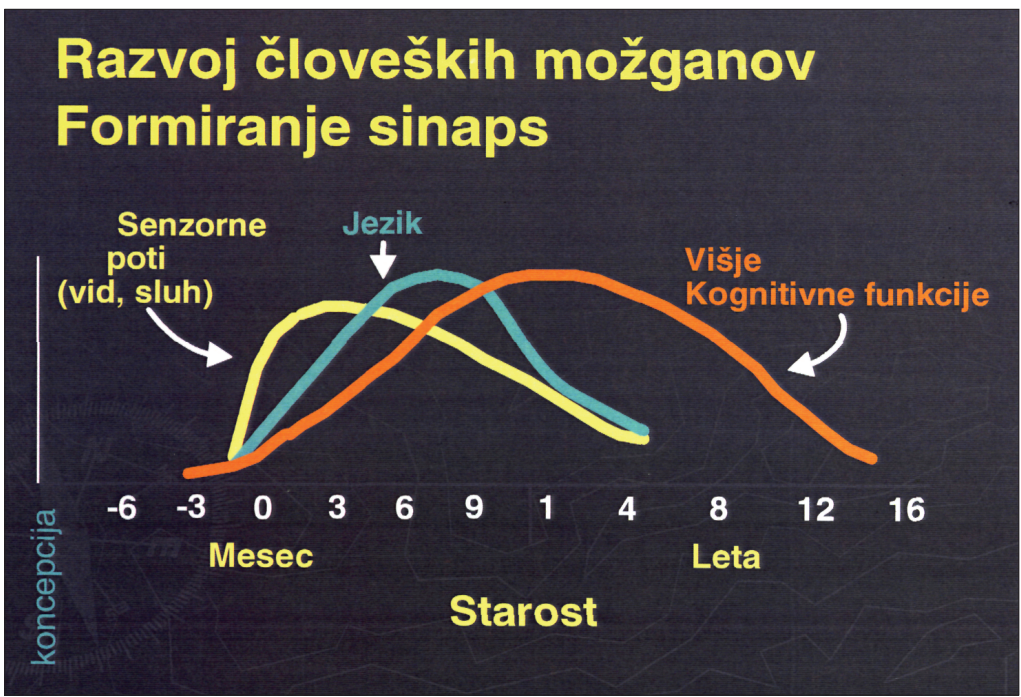

Slika 3: Razvoj človeških možganov z ozirom na formiranje sinaps za različne funkcije. $^{14}$

Človeški možgani imajo neverjetno zmožnost spreminjanja, vendar je, kot smo že spoznali, časovna uskladitev pri tem kritična. Spoznanje, da se možgani lahko spreminjajo, dokazuje, da možgani niso statičen organ, zato tudi sposobnosti posameznika niso določene ob rojstvu. V resnici si možgani sami lahko pomagajo pri spreminjanju ali nadomeščanju s pravočasno intervencijo. Posebej v prvih desetih letih življenja (še posebej pa v prvih nekaj letih) je ta sposobnost možganov še posebej velika. Ko se učenje nadaljuje skozi vse življenje, obstajajo samo optimalna obdobja priložnosti, v katerih so možgani posebej učinkoviti za specifične načine učenja. Nevrologi jih imenujejo kritična obdobja.

V otrokovem razvoju obstajajo kritične točke, v katerih morajo otroci imeti določene vrste izkušenj, ki omogočajo in podpirajo rast in razvoj. Časovno usklajevanje izkušenj je lahko zelo pomembno. Obstajajo obdobja v življenju, ko so možgani še posebej odprti za nove izkušnje. Če ta posebej občutlji-

${ }^{14}$ Nelson, povzeto po: J. F. Mustard, n. d. 
va obdobja minejo tako, da možgani ne dobijo stimulacij, za katere so pripravljeni, se možnosti za različne vrste učenja lahko bistveno zmanjšajo.

Prilagodljivost možganov hkrati pomeni, da obstajajo obdobja, ko imajo negativne izkušnje ali odsotnost primernih stimulacij bolj verjetno resne in trajne posledice. Tako ugotavljajo, da ima lahko materina depresija med šestim in osmim mesecem otrokove starosti hude posledice za otrokov razvoj. Nikotin, alkohol, kokain prav tako trajno vplivajo na otrokov razvoj. Izpostavljenost travmatičnim dogodkom vpliva na stopnjo anksioznosti, depresijo, navezanost na druge. Veliko teh faktorjev ponavadi nastopa naenkrat in skupaj, velikokrat pa so povezani tudi z revščino, tako da je krog vseh faktorjev zelo težko analizirati.

5) Dokazana je učinkovitost preventive in zgodnje intervencije. Vse več študij dokazuje, da intenzivna, dobro oblikovana, časovno usklajena intervencija lahko izboljša možnosti za uspeh in kakovost življenja za veliko otrok, ki jih opredeljujemo kot otroke s posebnimi potrebami. Intervencijski programi pa lahko pomagajo tudi otrokom iz okolja z nižjo formalno izobrazbo. Videti je, da je vpliv intervencijskih programov daljnosežen, posebej če se nadaljuje tudi tekom osnovnega šolanja. Čeprav ni nikoli prepozno za intervencijo, da bi izboljšali kakovost otrokovega življenja, ima zgodnja intervencija najbolj pomembne učinke na otrokov razvoj in učenje.

6) Vzgoja, nega in učenje v predšolskih letih imajo odločilen in trajen vpliv na to, kako se bodo ljudje razvijali, na njihove zmožnosti učenja in upravljanja ter reguliranja čustev. Način, kako se starši in drugi, ki skrbijo za otroka, odzivajo otroku, kako posredujejo v otrokovem stiku s svetom, neposredno vpliva na oblikovanje živčnih poti. Posebej otrokova zmožnost kontrole čustev je očitno odvisna od biološkega sistema, ki ga je posameznik oblikoval $\mathrm{v}$ najzgodnejših izkušnjah in $\mathrm{v}$ procesu povezanosti s tistimi, ki skrbijo zanj. Nevrologi so ugotovili, da ima močna in varna povezanost s tistim, ki skrbi za otroka, lahko zaščitno funkcijo in pomaga premagovati strese vsakodnevnega življenja. Kortizol, ki se sprošča ob stresnih situacijah, namreč direktno vpliva na metabolizem, imunski sistem in na možgane. $\mathrm{V}$ možganih uničuje nevrone in tudi sinapse na nekaterih delih možganov. Pri tem pa se zavedamo, da ni enoznačnosti pri oblikovanju toplega in razumevajočega procesa, ker se ta lahko pojavlja v različnih oblikah.

Če povzamemo, lahko trdimo, da so za otrokov razvoj pomembne tako izkušnje kot geni in da lahko razvoj možganov opišemo kot ples med geni 
in okoljem. ${ }^{15}$ Vsekakor pa so nam nevrološke raziskave možganov dokazale, da je razvoj možganov mnogo bolj občutljiv za vplive okolja, kot smo predvidevali. Kakovost interakcije otrokovih izkušenj glede zdravja, nege, prehrane in stimulacije $\mathrm{v}$ prvih mesecih in letih vpliva na razvojne zmožnosti otroka. Časovna uskladitev vplivov iz okolja s kritičnimi obdobji v zgodnjem razvoju je pri tem pomembna. Za otroke iz nespodbudnega in rizičnega okolja so ustrezni stimulusi iz okolja pomembni zlasti v prvem letu in pol, ${ }^{16}$ saj sicer njihova odsotnost lahko pomeni nepreklicen deficit v kasnejšem življenju. Prav najzgodnejši del našega življenja je kritičen za formiranje naših zmožnosti, osebnosti in socialnega vedenja, učinki zanemarjanja pa se v tem času še kumulirajo.

Čeprav bodo naslednja leta podala še vrsto novih in poglobljenih spoznanj o delovanju možganov in učenju, pa nam že doslej nakopičena spoznanja nudijo okvir za ukrepe, ki naj upoštevajo pomen medsebojnega vplivanja faktorjev dednosti in okolja, pomen močne in varne povezanosti $\mathrm{v}$ prvih letih otrokovega življenja, širino in hitrost razvoja v prvih desetih letih življenja, neverjetno plastičnost možganov, razumne in učinkovite prevencije ter visoko kvalitetne in dobro oblikovane programe za predšolske otroke. Vse bolj pomembno postaja zagotavljanje »obogatenega« okolja. Teorijo obogatenega okolja je prva ponudila nevrobiologinja Mariane Diamond. Diamondova je opisala rast dendritov v možganih kot razvoj »magičnega drevesa uma«, kjer se dendriti razcvetijo v okolju, bogatem z dražljaji in se sušijo tam, kjer je okolje osiromašeno. ${ }^{17}$ Znaki in zvoki obogatenega okolja spodbujajo dendrite, da tvorijo živčne poti. Izjemna voljnost in prilagodljivost možganov po dokazih, ki so jih zbrali Diamondova in njeni nasledniki, omogočata, da z obogatitvijo okolja pride do odebelitve korteksa (možganske opne), do večje razvejanosti dendritov in do večjega telesa (jedra) nevrona. To pa omogoča boljšo komunikacijo med nevroni. ${ }^{18}$

Ob teoriji obogatitve okolja pa se seveda nujno pojavlja vprašanje, kakšni pogoji so tisti, ki omogočajo boljšo strukturo možganov. Jensen na osnovi novejših raziskav povzema: ${ }^{19}$

- Pomen izzivov, ki ne smejo biti niti prelahki niti pretežki (in jih predstavljajo npr. novi materiali, višja zahtevnost, omejitev virov, spreminjanja

\footnotetext{
${ }^{15}$ Judith Evans, Arguments in Support of Investment in Early Childhood, Materials for Global Leaders Group, 2008.

${ }^{16} \mathrm{~J}$. Evans, n. d.

${ }^{17}$ Povzeto po: Robin Fogarty, Architects of the Intellect, Educational Leadership 57/3 (1999), 78.

${ }^{18}$ E. Jensen, Teaching with the brain in mind, Alexandria, Virginia 1998, 30.

${ }^{19}$ E. Jensen, n. d.
} 
časa, ki je na voljo, pričakovanj, pomoči pri učenju, spreminjanje učnih metod, okolja v oddelku, mesta izvajanja učenja, virov, ki jih uporabljamo, strukture skupin, reševanje problemov, kritično razmišljanje, ustrezni projekti, kompleksne dejavnosti, ipd.). Pri tem je nadvse pomembno vedenje o tem, da kar predstavlja izziv za enega otroka, ni nujno tudi izziv za drugega. Zato je ustvarjanje možnosti izbire v učnem procesu izjemnega pomena. Tu seveda ne mislimo le na možnost izbire vsebine, ampak predvsem strategij, s katerimi bomo omogočili različnim otrokom kar najboljše učenje.

- Poleg izzivov pa obogatitev predstavlja tudi povečanje povratnih informacij otroku. Povratne informacije (feedback) zmanjšajo negotovost, povečajo sposobnosti premagovanja in obvladovanja stresa. Možgani so oblikovani tako, da delujejo na principu feedbacka. Reakcija mora biti specifična, takojšnja, lahko pa se izvaja na različne načine (oblikovanje kriterijev, preverjanje v odvisnosti od ciljev, ki si jih posameznik zastavi, preverjanje s strani staršev ipd.).

- Končno naj med obogatitvenimi faktorji omenimo še branje, pisanje, poslušanje, govorjenje, raznovrstne motorične dejavnosti, reševanje problemov (pri čemer je dokazano, da nevroni rastejo zaradi procesa reševanja, ne pa zaradi rešitev - torej ne glede na to, ali otrok pride do rešitve ali ne), umetniške dejavnosti, obogateno fizično okolje, možnost izbire ter raznolikost.

Prva leta otrokovega življenja so torej namenjena predvsem povečevanju povezav med nevroni. Ta proces pa ni odvisen le od hrane in zdravja otroka, ampak tudi od vrste interakcij, ki jih otrok razvije z ljudmi in s stvarmi $\mathrm{v}$ svojem okolju. Ugotovitve na področju delovanja in razvoja možganov so zato v zadnjem času močno okrepile zanimanje strokovne javnosti prav za najzgodnejše obdobje otrokovega življenja, s tem pa so vplivale tudi na organizirano predšolsko vzgojo v tem obdobju ter na pogoje, ki naj bi jih v organizirani predšolski vzgoji v tem najzgodnejšem obdobju dosegli za kakovostno spodbujanje otrokovih potencialov. Tako zasledimo izjemno veliko zanimanja prav za organizirano predšolsko vzgojo v prvih treh letih življenja in poudarjanje pomena kvalitetnih pogojev življenja v tem obdobju. Seveda pa obogateno okolje lahko vpliva na otrokov ugodnejši razvoj tudi kasneje.

Spoznanja o delovanju možganov so skupaj z drugimi spoznanji močno spremenila pogled na to, kakšna naj bi bila organizirana predšolska vzgoja. Še več, ta spoznanja so na nek način spremenila poglede na poslanstvo organizirane predšolske vzgoje. Ta ni več prvenstveno namenjena pripravi na 
šolo. Dozorelo je celo spoznanje, da se bo morala šola prilagoditi in pripraviti na otroke, kakršni bodo prihajali vanjo. Bolj kot o premagovanju primanjkljajev na prehodu iz vrtca v šolo (kompenzacijska naravnanost predšolskih programov) govorimo o zagotavljanju kontinuitete $\mathrm{v}$ pristopih $\mathrm{k}$ otrokom in učenju in o pripravljenosti šole za otroke. In v tem kontekstu se je morala spremeniti tudi šola.

Po mnenju Shorove ${ }^{20}$ bo nevrološka znanost v prihodnje bolj kot splošnim vprašanjem o tem, kako se formirajo možganske povezave, usmerjena $\mathrm{k}$ bolj specifičnimu raziskovanju posameznih delov možganov in opazovanju, kako ter koliko nanje vpliva okolje. Že dosedanje ugotovitve pa po njenem mnenju nudijo osnovo za tri osnovne principe v delovanju:

1) Najprej, ne škodujmo: načelo, ki ga sicer poznamo iz medicine, naj bi se preneslo na druga področja politik in praks, ki zadevajo otroke. Vsekakor je najbolj pomembno omogočiti staršem, da izpolnijo svojo najpomembnejšo nalogo v zagotavljanju občutljive skrbi in nege za otroka. Politike, ki staršem ne omogočajo oblikovanja močne, varne povezanosti s svojim dojenčkom v prvih mesecih življenja, morajo doživeti reformo. Ob tem pa starši potrebujejo več informacij o tem, kako način nege in skrbi za otroke vpliva na otrokove kapacitete. Ta princip prav tako pomeni, da je potrebno vložiti dodaten napor za izboljšanje kakovosti organizirane predšolske vzgoje tako, da bodo starši zanesljivo vedeli, da se emocionalni razvoj in učenje njihovega otroka krepi, medtem ko oni delajo.

2) Preventiva je najboljša, če pa otrok potrebuje pomoč, naj bo intervencija hitra in intenzivna. Če vemo, da imajo zgodnje izkušnje tako močan vpliv na razvoj možganov, je seveda mogoče, da smo zaskrbljeni že pri vsakem neugodnem občutku ali izkušnji, ki jo otrok doživi. Družine bi morale vedeti, da v večini primerov odgovorna skrb ščiti otroke v ovirah vsakodnevnega življenja. V večini primerov si otroci opomorejo tudi pri resnih stresnih situacijah in travmah. Če pa jim pravočasno nudimo intenzivno in stalno pomoč, lahko prebrodijo celo paleto resnih razvojnih problemov.

3) Podpirati zdrav razvoj in učenje vsakega otroka. Če zamudimo možnosti za podpiranje zdravega razvoja in učenja v najzgodnejših mesecih in letih, je lahko kasnejše posredovanje težje in dražje in tudi manj učinkovito. Vendar to še ne pomeni, da je vse zamujeno, saj obstaja vrsta primerov, ki pričajo o obnovi kapacitet po tem, ko je kritično obdobje razvoja že minilo. Napori za višanje kognitivnega, emocionalnega in socialnega razvoja otrok ter odraslih morajo biti prisotni v vseh fazah življenjskega cikla.

${ }^{20}$ R. Shore, Rethinking the Brain: New Insights into Early Development, New York 1997. 
Odkritja o delovanju in razvoju možganov so dodobra razburkala sodobno predšolsko vzgojo in ji hkrati dala trdno znanstveno osnovo za zagovorništvo in širjenje. Ob ugotovitvah o razvoju možganov in ugotovitvah o povrnjenih investicijah v kvalitetne predšolske programe ter uresničevanju konvencije o otrokovih pravicah, področje predšolske vzgoje končno dobiva veljavo, ki si jo zasluži.

\section{Otrokov razvoj in učenje}

Konstruktivistična razlaga razvoja in učenja v tem obdobju med drugim pridobiva vse več zagovornikov tudi zato, ker strokovnjaki in znanstveniki iščejo najboljše načine za učenje in poučevanje, saj so tradicionalne metode postajale vse manj uporabne za uresničevanje novih ciljev. Raziskovalci, vzgojitelji in učitelji so ugotavljali, da tradicionalne metode povzročajo primanjkljaje v razumevanju ter pasivno znanje ${ }^{21}$ psihologi pa dokazujejo, kako zelo pomembna je aktivna udeležba $v$ učenju, ki vodi v boljše pomnjenje, razumevanje ter aktivno rabo naučenega. ${ }^{22}$ Konstruktivizem ima svoje argumente tudi v filozofskem smislu, saj dražljaji in sporočila niso nikoli zadostna, da bi prenesla pomen. Posameznik do neke mere vedno konstruira ali rekonstruira, kaj stvari pomenijo.

Interakcijsko-konstruktivistično tezo o odnosu med zorenjem in vplivi iz okolja potrjujejo tudi najnovejše raziskave o delovanju možganov in opozarjajo, da se neprestano medsebojno delovanje med obema faktorjema začne že pred otrokovim rojstvom, saj možgani zarodka še pred rojstvom sprejemajo informacije iz okolja in tvorijo možganske povezave, ki kasneje odločilno vplivajo na razvoj in učenje. Ko se otrok razvija in zori, gradi svoje lastno notranje vedenje - znanje v interakciji s svojim okoljem. Razvoj in učenje sta torej rezultat interakcije med otrokovim naravnim zorenjem in vplivi iz okolja. Pri tem pa se šele zadnjih deset, dvajset let v teh vprašanjih poudarja tudi pomen širšega kontekstualnega pristopa k razumevanju okolja oziroma sistema, v katerem se otrok razvija, saj so izkušnje, ki jih posameznik dobi, kulturno in socialno obarvane in so torej v odvisnosti od okolja, $\mathrm{v}$ katerem se otrok rodi oziroma živi. Individualne razlike lahko razložimo z razlikami v načinih, $s$ katerimi se posamezniki na različnih razvojnih nivojih odzivajo na dogodke in ljudi v svojem okolju. Pri tem je »človekova izkušnja konstrukcija realnosti $\ll,{ }^{23}$ realnost pa je kulturno in socialno pogojena.

\footnotetext{
${ }^{21}$ Howard E. Gardner, The unschooled mind, New York 1991.

${ }^{22}$ David Perkins, The many faces of Constructivism, Educational Leadership 57/3 (1999), 6-11.

${ }^{23}$ Sandra Scarr, Developmental theories for the 1990's: Development and individual differences, Child Development 63/1 (1992), 5.
} 
Osrednjo vlogo v strokovnih diskusijah prevzema predvsem vprašanje upoštevanja različnega kulturnega konteksta pri raziskovanju otrokovega razvoja, torej področja, ki je bilo zgodovinsko gledano, usmerjeno predvsem na raziskovanje otrokovega razvoja in učenja v kulturi »bele rase«.

Ob vsem tem je seveda razumljivo, da je v zahodnem svetu v tem obdobju vse bolj popularna sociokulturna teorija ali teorija socialnega konteksta in konstrukcije pomena L. Vigotskega. ${ }^{24}$ Vigotski se je zanimal za učinke kulture na razvoj, vendar je bil njegov interes usmerjen predvsem na kognitivni razvoj, tako kot je bil nanj usmerjen Piaget. Vigotski je tako kot Piaget verjel, da otroci konstruirajo svoje znanje in ga ne le »vzamejo vase «.

Lev Vigotski je zašel na področje izobraževanja kot srednješolski profesor literature in morda je prav zato prinesel nov veter $\mathrm{v}$ razumevanje učenja in poučevanja. Sodi med pomembne osebe, ki so zaznamovale pedagogiko že v začetku dvajsetega stoletja. Toda mnogo bolj odmevne so njegove ideje šele konec dvajsetega stoletja, za kar obstaja kar nekaj razlogov:

- Zagovarjal je kvalitativne in kvantitativne metode raziskovanja, kar ustreza sodobnemu razumevanju spoznavanja in odkrivanja na področju družboslovja.

- Od vzgojitelja pričakuje, da bo otroka opazoval, spraševal in spodbujal interakcijo z vrstniki. Vzgojitelj naj bi razmišljal o tem, kdaj naj otroku pomaga s predlogom ali idejo in kdaj naj ga pusti, da stvar opravi sam.

- Poudarjal je pomen socialnega okolja na človekov razvoj, s čimer je nudil tudi osnovo za študije, ki se odvijajo v različnih kulturnih okoljih. Poudarjal je tesno povezanost socialnega in kognitivnega razvoja in njuno medsebojno odvisnost. Pod vplivom Piageta je dotlej prevladovalo mnenje, da otrok konstruira znanje z osebno izkušnjo. Vigotski pa meni, da se otrok ne uči le s počenjanjem, ampak tudi z govorjenjem in počenjanjem z drugimi ter vztrajanjem pri nalogi, dokler je ne izpolni. Vzgojitelj lahko v pomoč otrokovemu socialnemu učenju omogoča možnosti, v katerih ti delajo skupaj in si medsebojno pomagajo.

- Vigotski meni, da osebna in socialna izkušnja ne moreta biti ločeni, saj je svet, v katerega se otrok »naseli«, oblikovan z njegovo družino, skupnostjo, s socialno ekonomskim statusom, z izobrazbo, kulturo... Njegovo razumevanje sveta je $\mathrm{v}$ določenem delu zaznamovano in prihaja od vrednot in prepričanj odraslih in drugih otrok, s katerimi prihaja v interakcijo v svojem življenju. Vigotski je prepričan, da se otroci vsak dan učijo drug od drugega, medtem ko se skupaj igrajo in komunicirajo. Tako

${ }^{24}$ R. Murray Thomas, Comparing Theories of Child Development, Belmont 1992. 
si razvijajo jezikovne zmožnosti in na nek način »ujamejo« koncepte, ko se pogovarjajo in poslušajo. Menil je, da isti mehanizmi, s katerimi se prenaša na otroka kultura, to je z interakcijo, sodelujejo tudi pri razvoju kompleksnega mišljenja. Otroci pridobivajo znanje v procesih delitve izkušenj z odraslimi ali z bolj razvitimi vrstniki. Dialog, ki spremlja to izkušnjo, postane del otrokovega vedenja, znanja. Tako je po mnenju Vigotskega socialna mediacija tista, od katere je odvisen kognitivni razvoj otroka. Ta trditev nasprotuje mnenju Piageta, ki verjame, da otrok postaja vse bolj socialen in manj egocentričen, saj je Vigotski pristaš ideje, da je otrok socialno odvisen od začetka kognitivnega življenja naprej in da ob socialnih izkušnjah z odraslimi in vrstniki postaja vse bolj neodvisen v svojem mišljenju.

- Tudi Vigotski je verjel, da se otrok veliko nauči, ko se igra z drugimi. Verjel je tudi, da jezik in igra gradita drug na drugem: ko se otroci igrajo, neprestano uporabljajo jezik in ta interakcija prispeva h konstruiranju znanja in učenja.

- Morda pa je še najbolj znana njegova ideja o pomenu interakcij otroka s starejšimi in z vrstniki. Razvil je idejo o coni bližnjega razvoja, ki jo lahko definiramo kot razliko med najtežjo nalogo, ki jo otrok lahko naredi sam, in najtežjo nalogo, ki jo otrok lahko naredi skupaj z drugimi oziroma s pomočjo drugih. Ko je otrok na meji, da bi se naučil novega koncepta, lahko z interakcijo z odraslim ali z vrstnikom močno pospeši svoj razvoj. Ta pomoč predstavlja oporo oziroma zidarski oder (scaffolding), ki mu pomaga priti na višji nivo razvoja veliko prej, kot pa če bi nalogo opravljal sam. Zato da bi lahko vzgojitelj nudil zidarski oder, pa mora dobro poznati otroka in ga opazovati, da bi ugotovil, kje se nahaja v razvojnem procesu in kam je sposoben priti ob upoštevanju njegovih individualnih potreb in socialnega konteksta, ki ga obkroža. Prav s cono bližnjega razvoja je Vigotski dal poseben pomen individualizaciji, v kateri se upošteva individualne značilnosti vsakega posameznega otroka in na ta način je tudi on postavil vsakega posameznega otroka $\mathrm{v}$ središče pozornosti vzgojitelja. S tem so ideje Vigotskega konsistentne z drugimi sodobnimi pristopi k vzgoji in izobraževanju.

- Ob spodbudnem okolju, ki ga otrok raziskuje, Vigotski poudarja tudi potrebo po tem, da vzgojitelji spodbujajo odkrivanje novega z modeliranjem, razlago in idejami, ki ustrezajo coni bližnjega razvoja. ${ }^{25}$

${ }^{25}$ Kelvin Seifert, Cognitive development in early childhood education, v: B. Spodek (ur.), Handbook on research on the education of young children, New York 1993, 9-23. 
Ob primerjavi pogledov, ki jih razlagata Piaget in Vigotski, se osnovna razlika kaže v poudarku, ki ga en ali drugi dajeta razmerju med notranjim organizmom in socialnim okoljem. Piaget pri tem poudarja znanje posameznika, ki ga oblikuje ob interakciji z zunanjim okoljem. Vigotski pa poudarja učinke socialno-kulturnih procesov, ki stimulirajo razvoj posameznika. Vigotski razmišlja tudi o tem, da moramo razlago za razvoj spreminjati v procesu samega razvoja. To pomeni, da lahko na določeni točki otrokovega razvoja biološki faktorji postanejo primarna sila sprememb, ko pa se otrok razvija in spreminja, nastopijo novi vplivi iz socialnega okolja, ki pripeljejo do razvoja. Čeprav se razvoj po njegovem mnenju še vedno odvija v danem biološkem okviru, postanejo vse bolj pomembni socialni faktorji.

Ob razmišljanju o odnosu med razvojem in učenjem Vigotski izhaja iz teze, da obstajata dva razvojna nivoja, na katerih otrok operira. Kot smo že omenili, prvi nivo označuje stopnjo, na kateri otrok lahko reši problem samostojno in ga Vigotski imenuje nivo aktualnega razvoja. Za drugi nivo operiranja pa je značilno, da isti problem otrok lahko reši ob pomoči, z vodenjem odraslega ali bolj razvitega vrstnika. Razdaljo med obema nivojema imenuje območje bližnjega razvoja. Ko otrok raste, postane potencialni nivo aktualni nivo. Vigotski tudi meni, da je za učenje odločilnega pomena, da se to območje oblikuje, saj se na ta način pri učenju zbudijo raznoliki notranji razvojni procesi, ki pa lahko operirajo le, če je otrok v interakciji z odraslim ali bolje razvitim vrstnikom v svojem okolju. Ko se ta proces internalizira (ponotranji), postane del neodvisnih razvojnih dosežkov. Menil je tudi, da je otrokom potrebno postavljati izzive in jih pri tem spodbujati k razvoju in ne le slediti temu, kar trenutno zmorejo. Zato Vigotski tudi trdno verjame, da otrok potrebuje pri raziskovanju in eksperimentiranju (s svojim okoljem) pomoč odraslega. Vlogo odraslega v otrokovem razvoju je razložil z nudenjem »zidarskega odra« oziroma opore, s katero odrasli pomagajo otroku, da se iz cone aktualnega (trenutnega) razvoja povzdigne $\mathrm{v}$ cono bližnjega oziroma jutrišnjega razvoja. ${ }^{26}$ In prav v tem delu svojega gledanja na razvoj se Piaget in Vigotski močno razlikujeta. Če bi to razliko prevedli v jezik predšolske prakse, bi lahko trdili, da se Piaget zavzema za »nevmešavanje « v otrokovo spoznavanje, kar z vidika vzgojitelja pomeni le pozorno opazovanje in sledenje, Vigotski pa se poleg tega zavzema še za aktivnejšo vlogo odraslega ali bolj razvitih vrstnikov, ki lahko razvoj otroka pospešijo. Za Vigotskega učenje ni samotarsko potovanje.

${ }^{26}$ Lev S. Vigotsky, Sobranije sočinjenij, I-II, Moskva 1982. 
Tako kot Piaget je tudi Vigotski verjel, da se razvoja ne da razložiti samo z enim faktorjem (biološkim zorenjem ali okoljsko-socialnim), ampak prihaja do razvoja ob interakciji bioloških in okoljskih faktorjev.

$\mathrm{V}$ tem obdobju se srečamo še z eno teorijo, ki je močno zaznamovala vzgojo in izobraževanje, pa tudi organizirano predšolsko vzgojo, to je teorijo multiplih inteligenc $\mathrm{H}$. Gardnerja. Gardner je definiral človekove potenciale $\mathrm{z}$ vidika zmožnosti za reševanje problemov v različnih kulturnih okoljih. ${ }^{27}$ Deslej je identificiral devet inteligenc (jezikovno, logično-matematično, prostorsko, glasbeno, kinestetično, medosebno, osebno, naturalistično in eksistencialno) in tako opozoril, da ne obstaja le ena pot k spoznavanju sveta in tvorjenju osebnega pomena. Hkrati pa je opozoril tudi na to, da obstajajo različne poti izražanja tega, kar otroci vedo in so zmožni narediti. To je v veliki meri spremenilo dotedanja gledanja na proces učenja ter spremljanje in ocenjevanje otrokovega razvoja in učenja. Zato je to obdobje izjemno močno zaznamovano tudi z iskanjem rešitev za uresničevanje individualnih pristopov $\mathrm{k}$ otroku in učenju. Individualizacija kot pedagoški pristop upošteva individualne značilnosti oziroma dimenzije individualnosti vseh (otrok in odraslih), ki vstopajo v pedagoški proces. Med dimenzijami individualnosti, ki so še posebej pomembne za uresničevanje individualizacije kot pedagoškega pristopa, je še posebej pomembno poznati družinsko kulturo, starost in razvojno stopnjo, učni stil, interese, podobo o sebi, temperament in druge osebnostne lastnosti. Vse to pa terja od vzgojiteljev sistematično opazovanje in zbiranje dejstev o vsakem otroku v skupini. Šele na osnovi zbranih dejstev, ki jih vzgojitelj zbira in ureja skozi daljše časovno obdobje, bo lahko podal tudi oceno otrokovega napredka. V naši praksi pa se žal še vedno preveč pogosto srečujemo s posplošenimi mnenji o otroku, ki niti staršem niti vzgojitelju ne nudijo dobre osnove za kakovostne spodbude. Ob vsem tem pa mora vzgojitelj dobro poznati tudi sebe in izkoristiti svoje močne strani v korist učenja otrok.

Povzetek spoznanj o otrokovem razvoju in učenju

Ob reševanju vprašanj o razvoju in učenju so se skozi zgodovino razvile različne teorije o otrokovem razvoju in učenju, ki so vplivale tudi na teoretične okvire gledanja na predšolskega otroka, njegov razvoj in učenje, $s$ tem pa tudi na zasnove organizirane predšolske vzgoje. Pri tem velja omeniti, da nobena dosedanja teorija o razvoju še ni uspela odgovoriti o njem na celosten način. Ko pride do teorij o predšolski vzgoji, večinoma ni jasne meje med napačnimi in pravilnimi teorijami. Čeprav so si nekatere teori-

${ }^{27}$ H. E. Gardner, Frames of mind: The theory of multiple intelligence, New York 1983. 
je celo v nasprotju, pa vsaka od njih lahko doprinese $\mathrm{k}$ boljšemu razumevanju otroka. V našem kratkem zgodovinskem prikazu smo seveda prikazali le najosnovnejše teorije, ki so se razvile skozi čas. Iz vseh našteti teorij pa vseeno lahko izluščimo pet principov, ki temeljijo na raziskavah o otrokovem razvoju in ki pojasnjujejo otrokovo rast in razvoj:

1) Razvoj na vsakem razvojnem področju vpliva in je vplivan z razvojem drugega področja. Ko otroci osvojijo določeno spretnost (npr. poskakovanje na eni nogi), običajno narašča njihovo zaupanje vase. Medsebojna odvisnost razvojnih področij je pomemben princip rasti in razvoja.

2) Razvoj se pojavlja v zaporednih in napovedljivih fazah. Rast poteka od zgoraj po telesu navzdol in od sredine proti periferiji. Pravila razvoja so enaka za vse otroke, vendar socialni in kulturni kontekst, v katerem otroci živijo, oblikuje njihov razvoj v različnih oblikah.

3) Razvoj poteka različno hitro pri različnih posameznikih pa tudi znotraj različnih razvojnih področij pri istem posamezniku. Tako obstaja velika raznolikost $\mathrm{v}$ pojavljanju določene rasti in razvoja, ki je pogojena $\mathrm{z}$ biološkimi faktorji, sociokulturnimi faktorji okolja, $z$ družino, $s$ temperamentom, z učnim stilom in izkušnjami. ${ }^{28}$ Le v primeru, če močno odstopajo od razvojnih mejnikov, je to lahko vzrok za razmišljanje o razvojni posebnosti, v smislu zaostajanja ali pa prehitevanja $\mathrm{v}$ razvoju.

4) Na razvoj močno vpliva vrsta izkušenj, ki jih ima otrok. Izkušnje pa imajo kumulativno naravo, zato lahko pozitivno ali negativno vplivajo na otrokovo znanje, spretnosti in sposobnosti. Izkušnje, ki jih ima otrok redno, so bolj močne in imajo trajnejše učinke od tistih, ki se pojavljajo redkeje. Otrok, ki doma posluša bogat jezik in redno »bere « oziroma posluša odrasle ali starejše vrstnike, ki mu berejo knjige, bolj verjetno kmalu razvije razumevanje različnih funkcij jezika, kar je velika prednost za kasnejše pisanje in branje. Otroci, ki ne slišijo govora ali imajo malo izkušenj s knjigami, so pogosteje ovirani pri kasnejšem razvoju pismenosti.

5) Razvoj je rezultat interakcije otrokovega biološkega, fizičnega in kulturnega okolja. Nobena teorija doslej še ni ustrezno opisala in razložila kompleksnega poteka otrokovega razvoja in rasti. Prevladuje pa mnenje, da sta biološki in okoljski faktor (kamor štejemo tudi kulturni faktor) prepletena in da njuna kombinacija tvori vsako osebo enkratno.

Ker nobena teorija ne pokriva vseh vidikov razvoja, je na sedanji stopnji razvoja organizirane predšolske vzgoje povsem naravno, da ta pristopa $\mathrm{k}$

${ }^{28}$ S. Bredekamp, C. Copple, Developmentally appropriate practice in early childhood programs (rev. ed.), Washington D. C. 1997. 
njim tako, da izbira in kombinira teorije ali elemente teorij, ki so združljivi $s$ filozofijo programa, cilji in načeli. V tem primeru je takšna stopnja eklektičnosti predvsem prednost in ne pomanjkljivost. Vedenje o tem, kako si razvoj razlagajo različne teorije, pa nam omogoča, da rabimo in uporabljamo tisto, kar je v določenem času in prostoru za določenega otroka ali skupino otrok najbolj ustrezno.

\section{Skriti kurikulum, osredotočenost na otroka in razvojno primerna praksa}

Strokovna javnost se je vse bolj zavedala tudi pomena implicitne pedagogike vzgojiteljic in vzgojiteljev, na katero se otroci odzivajo celo močneje kot na načrtovane in odkrite zahteve. Kroflič meni, da je ta implicitna pedagogika, ki se odraža v skritem kurikulu, še posebej pomembna na predšolski stopnji, ko se otrok na vzgojne spodbude iz svoje okolice odziva bolj čustveno in je še posebej odvisen od občutka sprejetosti in varnosti. ${ }^{29}$ Teorija skritega kurikula opozarja na številne nenamerne, a učinkovite dejavnike, ki vplivajo na otrokovo učenje in razvoj v pogojih vrtca, kot so npr. opremljenost, organizacija prostora, komunikacija in interakcija z otroki in med otroki, raba pohvale in graje, pravila, število otrok v skupini. ${ }^{30}$

Druga značilnost, ki se pojavlja v sodobni organizirani predšolski vzgoji, se nanaša na pristope, ki v središče učnega procesa in tega, kar se dogaja v vrtcu in šoli, postavljajo otroka. V literaturi jo poznamo pod imenom »child-centered «. Načeloma obstajajo trije programski pristopi, ki se med seboj razlikujejo glede na položaj otroka in vzgojitelja (učitelja) v njem. Tako poznamo model, ki ga usmerja vzgojitelj (teacher-centered) in v katerem le-ta prevzema popolno odgovornost za vse, kar se dogaja. Cilji in aktivnosti so vnaprej določeni s strani odraslih, zato pogosto obstajajo celotni izdelani kompleti za izvajanje kurikula. Vzgojitelj si prizadeva čim bolj dosledno uresničiti vse, kar se od njega pričakuje. Drugi pristop v bistvu predstavlja nasprotje prvemu. $\mathrm{V}$ njem otrok prevzema celotno iniciativo, vzgojitelj (učitelj) pa mu sledi. Otroku zaupajo v tolikšni meri, da menijo, da bo začel svojo aktivnost, se učil in evalviral. Vzgojiteljeva vloga je omejena na pripravo obogatenega, varnega in stimulativnega okolja, v katerem se lahko otroci svobodno igrajo, zbirajo aktivnosti in materiale ter si določajo svoje lastne cilje. Ta pristop se imenuje »child-initiated «. Končno pa obstaja še tretji pristop, v katerem otroci in vzgojitelji (učitelji) izme-

\footnotetext{
${ }^{29}$ Robi Kroflič, Temeljne predpostavke, načela in cilji kurikula za vrtce, v: L. Marjanovič Umek, Otrok v vrtcu - Priročnik h kurikulumu za vrtce, Ljubljana 2001.

${ }^{30}$ Kornelija Špoljar, Novi pristopi vzgojnoizobraževalnim programom v sodobnih konceptih predšolske vzgoje, Educa 3/1-2 (1993), 13-20; Kurikulum za vrtce, Ljubljana 1999.
} 
nično dajejo pobude za dejavnosti. V tem primeru »gre za balet med občutljivim odraslim in otrokom, $\mathrm{v}$ katerem oba nadzorujeta situacijo, oba dajeta pobude, oba odgovarjata, oba se ravnata glede na drugega $\ll .{ }^{31} \mathrm{~V}$ tem primeru vzgojitelj sicer usmerja in vodi otroke, postavlja cilje, vendar tako, da pri tem odgovarja otrokom, njihovim interesom, individualnim značilnostim, interesom ter njihovemu ozadju. Vse, kar počno vzgojitelji, počno $\mathrm{v}$ korist otroku. Zato je vsak otrok v skupini v centru vzgojiteljeve pozornosti pri načrtovanju, izvajanju in evalvaciji kakršnekoli dejavnosti.

$\mathrm{Na}$ otroka osredotočeni programi in učenje so se v zadnjih dveh desetletjih utrdili zaradi intenzivnega poudarjanja otrokovih pravic kot osnove predšolske vzgoje. Pristopi, ki so osredinjeni na otroka in njegovo korist, so namreč konsistentni z njegovimi pravicami, kot jih določa Konvencija o otrokovih pravicah. Ti pristopi pa predstavljajo tudi odziv na pasivno razumevanje učenja in otrokovega položaja v vzgojnem procesu, ki akumulira informacije skozi serijo okrepitvenih tehnik v aktivnega učenca, in ki uporablja učne strategije, $s$ katerimi odkriva in procesira informacijo. ${ }^{32}$

Po mnenju McCombsa in Whislerja osredotočenost na otroka oziroma učenca pomeni, da veš, kako vsak otrok »razume svoj svet in kako pristopa k procesu učenja «. ${ }^{33}$ Osredotočenost se po njunem mnenju nanaša na pet osnovnih principov:

1) Na otroka osredotočeno učenje uresničuje otrokove osnovne učne potrebe. Vsak otrok ima tri osnovne učne potrebe: potrebo po pripadanju in občutku podpiranja, potrebo po osebni kontroli ter odgovornosti in potrebo, da dokaže svojo zmožnost pri smiselnih učnih izkušnjah. ${ }^{34}$ $\mathrm{Na}$ učenca osredotočen pristop upošteva vse te potrebe tako, da postane učenje smotrno za otrokovo življenje, da razvije pozitivna čustva, ohranja otrokovo motivacijo in vključenost ter uspeh pri učenju. Smiselnost učnih izkušenj pa Wortham ${ }^{35}$ opredeljuje z naslednjimi lastnostmi:

- za otroka so pomembne in torej povezane z otrokovimi realnimi izkušnjami, interesi, znanjem in razširjajo tisto, kar otrok že ve;

${ }^{31}$ C. Seefeldt, N. H. Barbour, Early Childhood Education, Merrill 1994, 19.

${ }^{32}$ American psychological association, Presidential Task Force on Psychology in Education, Learner-centred psychological principles: Guidelines for School redesign and reform, Washington D. C. 1993; Daniel Goleman, Emotional intelligence, New York 1995; Lev S. Vigotsky, Mind in Society, Cambridge MA. 1978.

${ }^{33}$ Barbara L. McCombs, Jo Sue Whisler, The learner-centered classroom and school: Strategies for increasing student motivation and achievement, San Francisco 1997, XII.

${ }^{34} \mathrm{~N}$. d.

${ }^{35}$ Sue C. Wortham, The integrated classroom: The assessment-curriculum link in early childhood education, Prence Hill 1996. 
- spodbujajo aktivno učenje, ki se pojavi, če so otroci mentalno vključeni v neposredno izkušnjo, ki jim bo pomagala povezati informacijo ali spretnost, ki se jo učijo s svojim življenjem. Takšno učenje se pojavi le, če spoštujemo otrokove ideje, modeliramo glasno razmišljanje, reševanje problemov, odkrivanje problemov in razmišljanje o znanem na drugačen način;

- če so otroci vključeni v načrtovanje svojega učenja, ker s tem povečamo možnost, da bomo upoštevali njihove potrebe, želje in sposobnosti. Skupno, srečujoče načrtovanje, kjer se srečajo tako otroci kot vzgojitelj s svojimi cilji, predstavlja most med tem, kar se zdi otrokom smiselno in tistim, kar naj bi jih naučili;

- povezujejo otrokov razvoj in vsebino določenega področja (predmeta). Danes vemo, da je holističen pristop $\mathrm{k}$ učenju pogojen tudi z delovanjem možganov, zato je potrebno v učnem procesu upoštevati vsa področja razvoja.

2) Na učenca osredotočeno učenje temelji na rezultatih proučevanja delovanja možganov. Nove raziskave na področju nevrologije in kognitivnih ved širijo naše vedenje o vlogi možganov pri učenju. Te raziskave predlagajo principe učenja, ki so osnovani na delovanju možganov in ki omogočajo pedagogom, da otrokom pomagajo postati boljši. ${ }^{36}$ Potrjujejo pa tudi to, kar so predšolski pedagogi že dolgo slutili: to je, da so najzgodnejša leta življenja najbolj kritično obdobje za gradnjo močnih osnov za učenje. Te raziskave tudi pojasnjujejo pomen prvih treh let življenja, ko se oblikujejo poti ožičenja v možganih za vse življenje. To ožičenje se oblikuje med otrokovo pozitivno stimulacijo z odraslimi, dogodki in predmeti. Vpliva pa tudi na to, kako se otrok uči, na njegovo interakcijo z drugimi, njegovo mnenje o sebi in o vsem, sčimer bo soočen skozi življenje. ${ }^{37}$ Razumevanje raziskav o delovanju možganov je pomembno za pripravo otrok, ki se bodo lahko učili spontano, neodvisno, sodelovalno, brez prisile, ${ }^{38}$ da bi postali uspešni državljani v 21. stoletju.

3) Na učenca osredotočeno učenje je usmerjeno na vseživljenjsko učenje. Izobraževalne izkušnje zadevajo otroka od njegovega rojstva do starosti. Bredekampova in Rosegrantova ${ }^{39}$ sta konceptualizirali način učenja novega znanja, spretnosti in stališč v učnem ciklu, ki ga izkusijo vsi otroci.

\footnotetext{
${ }^{36}$ R. N. Caine, G. Caine, Education on the edge of possibility, Alexandria 1997.

${ }^{37}$ N.d.

${ }^{38}$ John Abbott, To be intelligent, Educational Leadership 54/6 (1997), 6-10.

${ }^{39}$ Sue Bredekamp, Teresa Rosegrant, Reaching potentials: Appropriate curriculum and assessment for young children, vol. 1, Washington D. C. 1993.
} 
Opisali sta štiristopenjski spiralasti in ponavljajoči se cikel, ki se začne z zavedanjem, se premika $\mathrm{k}$ raziskovanju, nato $\mathrm{k}$ poizvedovanju in na koncu k uporabi. Ta krog se večkrat ponovi, saj v trenutku, ko določeno znanje uporabimo, že razvijemo novo zavedanje o znanju, ki ga še ne obvladamo. Večkrat ko ponovimo učni cikel, globlje je naše znanje ali spretnost.

4) Na učenca osredotočeno učenje poudarja pomen socialnih, emocionalnih in intelektualnih zmožnosti pri učenju. Pomemben cilj šolanja za vse otroke je, da bi ti postali izobraženi, odgovorni in skrbni odrasli. ${ }^{40}$ $\mathrm{Na}$ otroka osredotočeni pristopi naravno omogočajo, da postane izobražen, ker naravno motivirajo otroka za učenje in mu pomagajo uporabljati informacije v njegovem življenju. Odgovorni postanejo tako, da jim omogočamo, da se odločajo in soodločajo o vsem, kar se tiče njih in drugih. Skrbnost pa spodbujamo tako, da jim omogočamo možnosti, v katerih spoznajo, da je skrb pomembna sestavina skupnosti, v kateri posamezniki skrbijo za druge in tudi zase. Sposobnost uravnavanja socialnega in emocionalnega vidika našega življenja v sodobnem, izjemno kompleksnem svetu, je pomemben, čeprav drugačen način »biti bistroumen « in je osnovna odgovornost vseh pedagogov. ${ }^{41}$ Sistematična skrb za otrokovo socialno in emocionalno zmožnost povečuje akademske dosežke, zmanjšuje problematično vedenje in izboljšuje otrokove medsebojne odnose. ${ }^{42}$

5) Na otroka osredotočeno učenje upošteva in spoštuje izkušnje, ki so inicirane in usmerjene s strani učenca. Učne izkušnje, ki naj bi omogočale otrokom, da prevzemajo nase določene odgovornosti za svoje lastno učenje, se označujejo kot samoinicirane in samokontrolirane. Kadar otrok lahko nadaljuje idejo, ki ga zanima, dobi odgovor na vprašanje, zakaj naj bi se nečesa učil. Ko se mu zaupa, da se lahko odloči za drugačno učno izbiro, mu v bistvu pomagamo prevzeti kontrolo in odgovornost za svoje lastno učenje, kar vpliva na motivacijo za učenje. ${ }^{43}$ Vzgojitelji, ki uvajajo na otroka osredotočene pristope, upoštevajo eno glavnih idej progresivne pedagogike. Po Deweyevem mnenju je glavni namen šolanja oziroma učenja pripraviti učence na resničnost današnjega in jutrišnjega dne. ${ }^{44} \mathrm{~V}$

\footnotetext{
${ }^{40}$ Association for Supervision and Curriculum Development, Promoting social and emotional learning: guidelines for educators, Alexandria, Virginia 1997.

${ }^{41}$ D. Goleman, n. d.

${ }^{42}$ Association for Supervision and Curriculum Development, Promoting social and emotional learning: guidelines for educators, Alexandria, Virginia 1997.

${ }^{43}$ B. L. McCombs, J. S. Whisler, The learner-centered classroom and school: Strategies for increasing student motivation and achievement, San Francisco 1997.

${ }^{44}$ J. Dewey, Democracy and education, New York 1916/1985.
} 
tem okviru vzgojitelji predpostavljajo, da znajo otroci dobro izbirati, da je proces učenja prav tako pomemben kot rezultati, ki jih otroci dosežejo, da je učenje odločanja pomembna spretnost ter osnovna pravica v demokratični družbi. Zato je od otroka inicirano in usmerjeno učenje pomemben del na otroka osredotočenega učenja, pri tem pa je pomembno, da se zavedamo pomena uravnoteženosti med učenjem, ki ga inicira otrok, in tistim, ki ga usmerja vzgojitelj. Tako otroci dobijo učne izkušnje, ki jih potrebujejo, da bi uspeli v tem kompleksnem svetu.

Reakcija na dotedanje razumevanje učenja in razvoja ter oblikovanja predšolskih programov pa je rodila še en zelo odmeven dokument. Konec 80. let prejšnjega stoletja je izšla knjiga »Developmentally Appropriate practice in Early Childhood Education Programs $\ll,{ }^{45}$ ki je na neki način združila strokovno mnenje največje in verjetno najbolj poznane strokovne organizacije na področju predšolske vzgoje NAEYC (National Association for Education of Young Children) o tem, kaj po mnenju članov te organizacije predstavlja kvalitetno predšolsko vzgojo. Dokument je bil deležen kritik predvsem zaradi neupoštevanja kulturne raznolikosti. Zato je leta 1997 nastala revidirana verzija tega dokumenta. ${ }^{46}$ Revidirani dokument ima sedaj tri osnove:

1) Razvojno primernost, ki temelji na tem, kar doslej vemo in razumemo o otrocih. Velja poudariti, da dokument ne temelji na tem, kar odrasliželijo, da bi otroci bili, ali pričakujejo, da bodo. Temelji na vedenju o tem, kako se otrok razvija in uči, vključno $z$ informacijami o primernih izkušnjah, materialih, aktivnostih in interakciji glede na starost in razvojni nivo.

2) Individualno primernost, za katero je značilno, da zahteva načrtovanje učnih izkušenj za vsakega otroka tako, da pri tem upošteva njegove močne strani, interese in potrebe. To pa zahteva, da odrasli spoznajo, da se vsak otrok razvija in uči na različen način in različno hitro.

3) Kulturna primernost, ki združuje vedenje o socialnem in kulturnem kontekstu, v katerem raste vsak otrok. Razvojno primerna praksa vključuje potrebe družin, njihove vrednote in kulturno osnovo v učne izkušnje otrok. $S$ spoštovanjem otrok in njihovih družin postane učenje za vse otroke relevantno, smiselno in pomembno.

Dokument, katerega namen je usmerjati strokovne odločitve, torej obravnava razvojno, individualno in kulturno primernost, ki jih je potreb-

\footnotetext{
${ }^{45} \mathrm{~S}$. Bredekamp, Developmentally appropriate practice in early childhood programs serving children from birth through age 8. Washington D. C. 1987.

${ }^{46} \mathrm{~S}$. Bredekamp, C. Copple, Developmentally appropriate practice in early childhood programs, Washington D. C. 1997.
} 
no pri odločitvah upoštevati. Vsaka od teh osnov pa je dinamična in se spreminja. To pomeni, da včasih tisto, kar je razvojno primerno, ni individualno ali/in kulturno primerno, ali pa tisto, kar je kulturno primerno, ni razvojno primerno ipd. V primerih, ko pride do razlik med strokovnim pogledom vrtca in pogledom staršev, ki so lahko individualno ali kulturno pogojene, je nujno potrebno vzpostaviti dialog med obema.

Razvojno primerna praksa ni kurikulum, je pa način, kako interpretirati kurikulum, ki temelji na tem, kar otroci vedo in naredijo $z$ upoštevanjem njihovih potreb, individualnih značilnosti in kulturnega ozadja. Vse, kar je bilo dokazano v raziskavah in formulirano v teorijah o tem, kako se otroci učijo in razvijajo na različnih starostih in razvojnih stopnjah, se v razvojno primerni praksi uporablja za oblikovanje kurikula, ki ustreza otrokovim potrebam in zmožnostim.

Še vedno pa med strokovnimi in znanstvenimi krogi lahko zasledimo diskusije o tem, kako dokument poimenovati. Katzova predlaga izraz za otroka občutljive (child sensitive) usmeritve prakse, nekateri drugi pa na raziskavah zasnovane (research-based) usmeritve prakse (razgovor s S. Bredekamp, april 2002).

\section{Partnerstvo z družinami}

Spoznanja o pomenu obogatenega okolja za otrokov razvoj in učenje so se nujno navezovala tudi na vlogo družine v skrbi za otroka. Čeprav tudi družina ob hitrih spremembah v družbi doživlja spremembe v vzorcih družinskega življenja, ta še vedno ostaja ena najbolj stabilnih sestavin družbe. Spreminja se sicer njena oblika in tudi vzorci družinskega življenja, vendar njene osnovne funkcije ostajajo enake. Čustveno povezuje člane med seboj, reducira izolacijo in odtujitev in daje občutek varnosti. Medtem ko sodobna družba postaja vse bolj odvisna od tehnologije, postajajo tudi člani družin vse bolj ločeni drug od drugega, zato postaja očitna potreba po tem, da skupnost in institucije (tudi predšolske) pomagajo družinam ustvarjati skrbno okolje za otroke. Potreba po tem, da spodbujamo medsebojne odnose, postaja zato še bolj pereča kot kdajkoli prej, ko je bila družina več časa skupaj.

V sodobni organizirani predšolski vzgoji ni več pomislekov o tem, ali obstaja potreba po sodelovanju med institucijo in družino. K temu je zanesljivo doprinesel tudi Jurij Bronfenbrenner s svojo teorijo kulturnega konteksta, v kateri opozarja na soodvisnost kontekstov, v katerih živi otrok, in njihovim vplivom na otrokov razvoj. Njegova teorija je močno vplivala na predšolske programe z vidika interakcije vzgojiteljev z družinami. Še vedno pa obsta- 
ja vprašanje, na kakšen način naj sodelujejo in kako naj bi bilo to sodelovanje kar najbolj dovršeno, da bi ustrezalo potrebam posameznih družin, vrtcev (šol) in okolij. V strokovni literaturi tako rekoč ne govorimo več o sodelovanju med institucijo in starši, ampak o sodelovanju med institucijo in družino. Ta sprememba odraža spoznanje, kako zelo je za otrokov razvoj pomembno celotno družinsko okolje oziroma mikrokultura družine in kako zelo pomembno je te faktorje upoštevati tudi pri organizirani predšolski vzgoji.

Sodelovanje med družino in institucijo prinaša močne strani družine ter strokovnost institucije v aktivno partnerstvo. Ločevanje otroka od družine je nemogoče, saj vsak otrok raste in se socializira v kulturi svoje družine. Otroci prinašajo svoje ideje, čustva, močne in šibke strani od doma v svoje življenje v vrtcu. Če sta družina in vrtec povezana preko otroka, bo to partnerstvo prispevalo k učinkovitosti vrtca. Raziskave ugotavljajo, da možnosti za otrokov uspeh naraščajo, če šola (vrtec) in družina delata skupaj. ${ }^{47}$ Epsteinova tudi opozarja, da pri tem še vedno srečujemo dvoje različnih stališč. $\mathrm{Na}$ eni strani so stališča zagovornikov skupnega dela družine in šole, v katerem si oboji delijo skupne cilje v odnosu do otroka. Na drugi strani pa imamo zagovornike ideje, da vrtec (šola) lahko najbolje doseže svoje cilje, če se družina ne vmešava v vrtec (šolo), ker s tem ogroža strokovni status in vzgojiteljevo oziroma učiteljevo strokovno odgovornost.

Vendar je prepoznavanje družine kot nekaj ločenega od vrtca in šole nenaravno. Kljub vsemu se spoznanje, da je družina otrokov prvi skrbnik, socializator in učitelj, ${ }^{48}$ vse bolj utrjuje. Vlogo staršev v prvih letih otrokovega življenja Bergerjeva opredeljuje s tremi vidiki:

- družba ne bi preživela, če v njeni kulturi ne bi bilo rojevanja in skrbi za otroke. Čeprav se način skrbi za dojenčke in malčke v različnih kulturah in tudi znotraj iste kulture razlikuje, je otrokova blaginja odvisna tako od te skrbi kot tudi od prožnosti otroka. Otrok, njegov skrbnik in okolje se prepletajo v procesu nege in vzgoje, zato so izkušnje vsakega otroka enkratne. Na tem spoznanju pa temelji tudi spoznanje o izjemni odgovornosti starševstva;

- raziskave o delovanju možganov dokazujejo, da dobre in slabe izkušnje, ki jih otrok pridobi v prvih letih življenja, vplivajo na povezave in oži-

\footnotetext{
${ }^{47}$ Joyce L. Epstein, Perspective and previews on research and policy for school, family and community partnerships, v: A. Booth, J. F. Dunn (ur.), Family-school links, Mahwah, New York 1996; Amy Laura Dombo, Nina Sazer, Ellen Galinsky, Nina S. O'Donnell, Sarah Melchar, Sarah Gilkeson, Abby Farber, Community Mobilization: Strategies to Support Young Children and Their Families, New York 1996.

${ }^{48}$ Eugenia Hepworth Berger, Parents as Partners in Education. Families and schools working together, Prentice Hall 2000, 8.
} 
čenje njegovih možganov. Današnji razvoj tehnologije je znanstvenikom omogočil pogled v možgane in tudi v nivoje aktivnosti, ki se dogajajo v možganih. ${ }^{49}$ Danes imamo znanstvene dokaze, da okolje vpliva na možgane in da otrokov možganski razvoj ni določen in fiksiran ob rojstvu, na kar so v svojih teorijah opozarjali Hunt, Piaget in Vigotski. Razvoj možganov je dinamična medsebojna dejavnost med naravo (dednostjo) in vzgojo (okoljem). Na možgane vplivajo nega, hrana in stimulacija, ki jih dobijo. Geni sicer igrajo pomembno vlogo v otrokovem razvoju, vendar so le del te enačbe. Človekov razvoj usmerjajo dinamični odnosi med naravo in vzgojo. ${ }^{50}$ Prepoznavanje pomembnosti vloge otrokovih izkušenj v njegovem razvoju pa krepi zahtevo po zagotavljanju ustreznega okolja za otroke;

- otroci, ki nimajo možnosti za oblikovanje navezanosti (attachment) na » pomembne druge « v prvih dveh letih življenja, zelo težko ali pa sploh ne morejo premagati pomanjkanja čustvene navezanosti. Vendar se sposobnost vzgajati in skrbeti za dojenčka ne razvije avtomatično. Vprašanju navezanosti namenjajo strokovnjaki pozornost že več kot sedemdeset let, saj tvori eno najpomembnejših pogojev za oblikovanje zdrave osebnosti. Bowlby je navezanost definiral kot lastno notranjo motiviranost, različno od hranjenja in spolnosti, vendar nič manj pomembno. ${ }^{51}$ Navezanost se izkazuje na ta način, da oseba kaže, da želi pridobiti in obdržati bližino z osebo, na katero je navezana (največkrat sta to mama, oče, lahko pa tudi kdo drug, ki ga otrok pozna). Večja je, če je otrok prestrašen, bolan, utrujen. Razvoj navezanosti je najbolj kritičen v prvih nekaj letih življenja. Doslej so dokazali tri skupine staršev, pri katerih bi lahko pričakovali probleme pri razvijanju navezanosti med nji$\mathrm{mi}$ in otrokom, in sicer so to starši, ki sami niso imeli modela dobrega starševstva, izolirani, negotovi starši, ki niso deležni sistema pomoči, in prezaposleni starši..$^{52}$

Sodelovanje predšolske institucije z družino zagotavlja razvojno kontinuiteto. Razvojno kontinuiteto lahko definiramo kot nepretrgano, povezano celoto v razvoju. Diskontinuiteta pa se nanaša na pomanjkanje kontinuitete oziroma na spremembe in motnje v otrokovem razvoju. Verjetno je nemogoče pričakovati, da bi v tako raznoliki družbi kot je naša lahko oblikovali kurikulum, ki bi zagotavljal odlično razvojno kontinuiteto za vse otro-

\footnotetext{
${ }^{49}$ R. Shore, Rethinking the Brain: New Insights into Early Development, New York 1997.

${ }^{50}$ N.d., 15.

${ }^{51}$ John Bowlby, A secure base, New York 1988, 27.

${ }^{52}$ E. H. Berger, n. d.
} 
ke, mogoče pa je graditi sistem podpiranja otrokove kontinuitete v razvoju. Vendar problem kontinuitete ne leži le v individualnih razlikah med otroki, ampak tudi v raznolikosti socialnih struktur, iz katerih prihajajo otroci, kar povzroča razlike med otrokovimi izkušnjami doma in $\mathrm{v}$ instituciji. V tem primeru lahko govorimo o kulturni diskontinuiteti otrokovih izkušenj. Zato postaja vse bolj pomembno zagotavljanje določene stabilnosti v okolju, ki otrokom pomaga pri adaptaciji na novo okolje. To spoznanje postavlja pred organizirano predšolsko vzgojo zahtevo po oblikovanju takšnih pogojev v okolju, da se otrok ne bo počutil, kot da prihaja v tuje okolje. Vrtec naj bi bil kulturno občutljiv oziroma občutljiv za kulturo in jezik otrokove družine.

Epsteinova opozarja, ${ }^{53}$ da imajo institucije šest osnovnih nalog v zvezi z vključevanjem družin:

- Omogočajo družinam, da si pridobijo znanja in spretnosti, ki so potrebne za to, da pomagajo svojemu otroku na vsaki starostni stopnji.

- Komunicirajo z družinami na zelo različne načine.

- Vključujejo družine kot prostovoljce v dejavnosti oddelka oziroma institucije.

- Pomagajo družinam, da bodo le-te lahko pomagale svojim otrokom (svetovanje, nadzor, pomoč pri domačem delu).

- Vključujejo družine v sprejemanje odločitev, komunikacijo z drugimi starši, vodenje in zagovorništvo.

- Vključujejo družine v prizadevanja za vključevanje vrtca (šole) v širšo skupnost.

V prizadevanjih za vključevanje družin se vse bolj poudarja aktivna vloga družin pri načrtovanju, implementaciji in evalvaciji programov, ki se uresničujejo v instituciji. Vse bolj se uveljavljajo tudi poskusi lokalnega načina vodenja institucije, $v$ katerega se aktivno vključujejo predstavniki družin. Da pa bi tovrstna dejavnost v resnici živela in bi družine imele svojo vlogo v tem procesu, potrebujejo sistem informacij in tudi določena znanja, ki jim omogočajo učinkovito odločanje in soustvarjanje politike na tem področju. V krog tistih, ki odločajo o organizirani predšolski vzgoji, tako poleg staršev sodijo še vzgojitelji, vodstvo vrtca in predstavniki skupnosti. Lokalni nivo vodenja seveda zahteva sposobnosti za sodelovalno vodenje. Ne glede na to, ali skupino vodi eden od staršev, ravnatelj ali strokovnjak, potrebuje določena znanja. Običajno pa ta vloga pripada ravnatelju. Tak

${ }^{53}$ Citirano po: E. H. Berger, n. d. 
način vodenja temelji na prepričanju, da tisti, ki so najbližje problemom, lahko najbolje odločajo in iščejo najustreznejše rešitve.

Pogostost, vsebina in uspešnost sodelovanja z družinami oziroma s starši je seveda odvisna od različnih dejavnikov. Zanesljivo pa sta vsaj dva dejavnika, na katera lahko vplivamo s strani delovanja institucije oziroma vrtca. To sta raznolikost ponudbe oziroma možnosti za sodelovanje ter klima oziroma kultura vrtca v odnosu do družin. Zavedanje raznolikosti nivojev sodelovanja in tudi načinov sodelovanja z družinami ter starši postaja vse bolj pomembna sestavina vseh organiziranih predšolskih programov.

Bergerjeva ${ }^{54}$ predstavlja sedem nivojev vključevanja staršev v življenje vrtca, in sicer:

- Starši kot aktivni partnerji in vodje prizadevanj za izobraževanje doma in v instituciji, ki so aktivno vključeni in predani ideji sodelovanja ter izjemno podpirajo svoje otroke.

- Starši, ki sprejemajo odločitve v svetu vrtca (šole) ali vodstvenem timu. Ponavadi imajo moč, da z odločitvami vplivajo na klimo institucije, svetovalnih komisij, so aktivni v sodelovalnem vodenju vrtca.

- Starši, ki predstavljajo zagovornike institucije.

- Starši, ki aktivno sodelujejo z institucijo kot prostovoljci, vendar so pri tem učinkoviti le, če dobijo navodila, opredeljene naloge in odgovornosti.

- Starši, ki podpirajo vez med vrtcem in domom tako, da podpirajo domače učenje oziroma izkušnje in se zavedajo obveznosti v odnosu do institucije. Pri tem je institucija za njih agencija, servis, ki izobražuje njihove otroke.

- Starši, ki se želijo izobraževati.

- Starši, ki niso aktivni, vendar podpirajo vzgojne in izobraževalne cilje institucije in spodbujajo otroka $\mathrm{k}$ učenju.

Epsteinova ${ }^{55}$ pa ponuja šest tipov sodelovanja, ki ga institucije lahko uresničujejo, da bi povišale sodelovanje med družinami, vrtcem (šolami) in skupnostjo:

1) Usposabljanje za starševstvo - predstavlja pomoč staršem z znanjem in $s$ spretnostmi, ki jim pomagajo razumeti otroka in njegov razvoj in oblikovati domače okolje, ki bo podpiralo učenje.

\footnotetext{
${ }^{54}$ E. H. Berger, n. d.

${ }^{55}$ Joyce L. Epstein, Perspective and previews on research and policy for school, family and community partnerships, v: A. Booth, J. F. Dunn (ur.), Family-school links, Mahwah, New York 1996.
} 
2) Učinkovito komuniciranje - predstavlja učinkovito komuniciranje na relaciji vrtec-dom in obratno - poroča o otrokovem napredku in programu.

3) Vključevanje članov družine kot prostovoljcev - predstavlja ustvarjanje pogojev za učinkovito delo prostovoljcev, kot sta npr. usposabljanje prostovoljcev in prožnost pri načrtovanju in organizaciji dela.

4) Posredovanje informacij o tem, kako se lahko otrok uči doma - da bi otrok pridobival ustrezne izkušnje doma ali da bi mu doma lahko pomagali pri učenju, naj bi vrtec nudil družinam ustrezne informacije, ki bodo povezale dogajanja v vrtcu in doma.

5) Sprejemanje odločitev - pri tem gre za vključevanje staršev v upravljanje vrtca in sprejemanje odločitev, ki zadevajo vrtec.

6) Sodelovanje s skupnostjo - ta način pa vključuje vsa tista prizadevanja, $s$ katerimi skušajo povezati in združiti različne servise (dejavnosti in organizacije) ter sredstva, ki so na voljo v skupnosti z vrtcem, da bi pripomogli k razvoju vrtca, šole, družin, programa, razvoja otrok in učenja.

Za kvalitetno vključevanje staršev v življenje vrtca seveda ni potrebno, da tipologije sodelovanja sledijo druga drugi. Prav tako ni potrebno, da bi ista družina sodelovala na vseh stopnjah. Pomembno pa je, da vzgojiteljica staršem v procesu participacije stoji ob strani in to ne glede na to, na kateri stopnji participacije ti želijo delovati. Gre za proces individualizacije na nivoju sodelovanja s starši, tako da bolj zainteresirane starše podpira v njihovi neodvisnosti in ustvarjalnosti delovanja na vseh ravneh, manj samozavestnim staršem pa nudi oporo in možnost, da rastejo v svojih vlogah in da se učijo drug od drugega. Starši imajo možnost izbirati oblike sodelovanja in participacije.

Katzova ${ }^{56}$ opozarja tudi na problem edukacije staršev ter dvigovanju pričakovanj in zahtev v odnosu do predšolskih programov. Rezultati raziskav $\mathrm{v}$ različnih državah kažejo, da so starši skoraj 100 odstotno zadovoljni s predšolskimi programi, strokovnjaki pa tega zadovoljstva ne kažejo. Katzova meni, da gre pri tem za poglavitno razliko v razumevanju predšolskega obdobja, saj strokovnjaki slab program vidijo kot zamujeno možnost za otroka, starši pa nimajo enakih spoznanj o pomenu in možnostih, ki jih nudimo otrokom v predšolskih programih. Pri tem pa se pojavlja še en problem, in sicer dejstvo, da so starši predšolskih otrok v resnici prehodna po-

${ }^{56}$ Lillian G. Katz, Bernard Cesarone, Razmišljanja o pristopu »Reggio Emilia«, ERIC/EECE Univerziteta u Illinois, Sarajevo 1994. 
pulacija, saj jim otroci kmalu zrastejo. Zato je rešitev le v kontinuiranem procesu sodelovanja s starši, pa tudi v osveščanju celotne skupnosti.

\section{Odzivi prakse}

Na vse opisane strokovne spremembe se je že sredi osemdesetih let odzvala tudi praksa. Razvili so se programi, ki so se odmikali od enostranskih kognitivno obarvanih kurikulov. Programi vse bolj poudarjajo pomen vseh razvojnih področij in celostnost v odnosu do njih. Hkrati poudarjajo tudi potrebo po upoštevanju individualnih vzorcev razvoja ter razlik med otroki na nivoju interesov, učnih stilov, osebnosti ipd. Vse bolj poudarjajo pomen stimulativnega okolja (fizičnega in človeškega), ki zagotavlja občutek varnosti, zdravja in hkrati spodbuja učenje. Vse več pomena namenjajo aktivni participaciji otrok v procesu pridobivanja za njih smiselnih izkušenj v konstrukciji znanja. Pri tem pa se posebej poudarja pomen ustrezne interakcije vzgojiteljic z otrokom ter pomen socialne interakcije otroka $\mathrm{z}$ drugimi otroki v oddelku. Vse več spoštovanja namenjajo tudi staršem, ki jih vse bolj aktivno vključujejo v življenje vrtca. Nenazadnje pa se vrtci vse bolj odpirajo $\mathrm{v}$ širšo skupnost in tako prispevajo k procesu ozaveščanja in odločanja javnosti o organizirani predšolski vzgoji.

Razvili so se tudi odprti programi, ki zajemajo celovitejši kontekst, v katerem se odvijata vzgoja in izobraževanje. Ti niso bili strukturirani in dokončni, ampak so predstavljali le okvir s splošno postavljenimi cilji kot orientacijo. Ti programi se razvijajo v procesu delovanja, ne poudarjajo le vsebin, metod in sredstev, ampak kvaliteto interakcije in odnosov. Pri njegovem nastajanju sodelujejo enakopravno otroci, starši, strokovnjaki in vzgojitelji. Ob stalnem dialogu se program razvija in izpopolnjuje. ${ }^{57}$

Eden od takšnih programov je Zimmerjev model situacijske pedagogike, ki je nastal na teh principih in se je razvil v Nemčiji konec sedemdesetih in na začetku osemdesetih let $\mathrm{z}$ imenom »Socialno učenje «. Model je bil širše pedagoško usmerjen na celostno oblikovanje bivanja v predšolski ustanovi. Zavzema se za deinstitucionalizacijo predšolskih ustanov in vzgoje v njih ter za razvijanje avtonomije. Vzgojne situacije, ki so osredotočene okrog določene teme, povezane z realnimi življenjskimi situacijami otrok, postanejo osrednja točka v tem pristopu, za katerega je značilno: - učenje in pridobivanje izkušenj je povezano z življenjskimi situacijami otrok,

\footnotetext{
${ }^{57}$ K. Špoljar, Novi pristopi vzgojnoizobraževalnim programom v sodobnih konceptih predšolske vzgoje, Educa 3/1-2 (1993), 13-20.
} 
- socialno učenje je najbolj pomembno,

- prednost se daje starostno mešanim skupinam,

- starši in drugi odrasli sodelujejo v programu s svojimi življenjskimi izkušnjami in ga bogatijo,

- otroci sodelujejo pri načrtovanju teme,

- vzgojitelji in otroci se učijo skupaj in drug od drugega,

- učenje se ne odvija le v vrtcu,

- načrtovanje procesa ni strukturirano, ampak fleksibilno, organizira se glede na situacije v spontanih interesnih skupinah,

- ureditev prostora spodbudno vpliva na otroka,

- vrtec je življenjski prostor otrok, staršev in vzgojiteljev, odprt navznoter in navzven.

Drugi primer odprtega kurikula, ki se je razvil v osemdestih letih prejšnjega stoletja, pa je znan pod imenom Regio Emilia. Razvili so ga strokovnjaki, združeni okrog Lorisa Malaguzzia (1920-1994) v skupnosti Regio Emilia v Italiji, kjer je skupnost začela financirati sistem predšolske vzgoje. Model izhaja iz Deweyevih idej (na otroka osredinjeni edukaciji), ki ga kombinira s Piagetovim konstruktivističnim pristopom ter s socialnim konstruktivizmom Vigotskega. ${ }^{58}$ Otroka pojmuje kot aktivnega udeleženca v konstrukciji svojega znanja, pri tem pa ga vidijo v relaciji $z$ družino in vzgojiteljem, pri čemer so te relacije medsebojno povezane in recipročne.

Fizično okolje omogoča privlačno, estetsko prijetno in udobno okolje, ki naj bi omogočalo učenje in odnose med otroci, med otroci in odraslimi in med odraslimi. Prostor omogoča komunikacijo in neguje odnose. Ureditev omogoča otroku, da dela sam, z vzgojiteljico ali pa v malih in v večjih skupinah. Dejavnosti omogočajo raziskovanje, odkrivanje ter reševanje problemov. Otrokom ponujajo veliko možnosti izbire. Prostorska ureditev omogoča srečevanja in zbiranje otrok, staršev in vzgojiteljev v osrednjem prostoru blizu vhoda, ki ga imenujejo trg v skladu $\mathrm{z}$ arhitekturo italijanskih mest. Vrtec pa ima tudi t.i. atelje oziroma likovno delavnico. Centri aktivnosti se ponašajo z osebno noto in $\mathrm{z}$ družinskim vzdušjem. Pozornost namenjajo tudi primerni osvetlitvi, razporeditvi ogledal in razstavljenim umetniškim eksponatom.

${ }^{58}$ Joanne Hendrick, First steps towards teaching the Reggio way, Prentice Hall 1997. 
Vzgojitelj, ki dela v ateljeju, je ponavadi specializiran na vizualne umetnosti. ${ }^{59}$ Vzgojitelji veliko pozornosti namenjajo dokumentiranju dela otrok, njihovih diskusij in aktivnosti. V pregled opravljenega dela, ki je usmerjen na proces učenja, se vključujejo otroci, starši in vzgojitelj, ki dela $\mathrm{v}$ ateljeju. $\mathrm{V}$ dnevnem redu sta določena le čas za kosilo in počitek. Kurikulum se vrti okrog projektov, pri tem pa umetniške dejavnosti predstavljajo motor, skozi katerega otroci raziskujejo koncepte oziroma vsebine, ki jih proučujejo. Ideje za projekte prihajajo od otrok ali od vzgojiteljev ali pa iz vsakodnevnih izkušenj. Osnovne cilje postavljajo vzgojitelji, vendar vnaprejšnjega planiranja ni.

Program je namenjen otrokom od štirih mesecev do šestega leta, pri tem so otroci do tretjega leta ločeni od starejših. Otroci ostajajo z istim vzgojiteljem in z vrstniki tri leta. Vzgojitelji delujejo v parih kot partnerji otrokom pri projektih. Vzgojitelji so predvsem raziskovalci, ki zbirajo informacije, dokumentirajo, opazujejo in razpravljajo. Sposobnost opazovanja in poslušanja ter refleksije dogajanja so pomembne lastnosti, ki jih imajo ti vzgojitelji. ${ }^{60} \mathrm{Za}$ dokumentiranje in sestanke imajo na voljo pet ur tedensko. Poleg vzgojiteljev in specialista za umetnost so v vrtcu še pedagog in psiholog. Posebno vlogo pa imajo tudi starši, ki jim nudijo udobno okolje za srečevanje v vrtcu, skrbijo pa tudi za redna skupna srečanja staršev in vzgojiteljev.

Na Malaguzzijev model učenja so močno vplivale ideje Vigotskega, zlasti njegova teorija con aktualnega in bližnjega razvoja. Prav tako so nanj močno vplivale ideje Deweya, ki se kažejo v poudarjanju sodelovanja na vseh nivojih (sodelovanja s starši, sodelovanja med pedagogi, sodelovanja med otroki, sodelovanje celotne lokalne skupnosti), ki prinaša posebno kulturo v te vrtce ter občutek stabilnosti, ki jo dosežejo tudi s stalnostjo pedagogov. Tudi v primeru modela Reggio Emilia je osrednje izhodišče programa otrok, njegove potrebe, njegov način spoznavanja sveta. Ena glavnih nalog vzgoje pa je razvoj otrokove identitete, ki se lahko realizira preko ustvarjalnosti. $\mathrm{Na}$ ta koncept vzgoje je močno vplivala tudi koncepcija Montessori, ki se kaže v poudarjanju čutil v procesu spoznavanja in zato tudi v razvijanju čutil. Prav čutni doživljaji naj bi tvorili osnovo izražanju - likovnemu, glasbenemu, govornemu in telesnemu. Vse metodične rešitve izhajajo iz celovitosti sveta in doživljanja življenjske realnosti, ki zajemajo spoznavno, čustveno in voljno komponento, in se med drugim ure-

${ }^{59}$ Lella Gandini, The Reggio Emilia story: History and organization. First steps towards teaching the Reggio way, Prentice Hall 1997, 1-13.

${ }^{60}$ Eva L. Essa, Rosemary Young, Introduction to Early Childhood Education, Ontario 2003. 
sničujejo v projektih. Katzova ${ }^{61}$ je pristope Reggio Emilia poimenovala kot najsvetlejši primer razvojno primerne in priporočljive prakse, vendar se ob tem sprašuje, če ga je sploh mogoče prenesti v drugačno okolje, saj je prav zavzetost lokalne skupnosti skupaj s starši eden glavnih dejavnikov uspešnosti tega modela.

Zanimivo je, da so ideje o otroku kot središču dogajanja v pedagoškem procesu že v osemdesetih letih predstavljene tudi v razmišljanjih strokovnjakov v takratni Sovjetski zvezi. Nastali sta kar dve med sabo zelo povezani gibanji. Eno je vodil akademik Amonašvili, ki je zgradil metodiko dela z otroki na prehodu iz vrtca v šolo ter na začetku šolanja na teoriji Vigotskega in jo predstavil pod imenom $\gg Z$ dravstvujte djeti $\ll,{ }^{62} s$ katerim je skušal opozoriti, da prepoznava in spoštuje otroka v vzgojnem procesu. Drugo gibanje pa je znano pod imenom »pedagogika sotrudničestva « ali pedagogika sodelovanja ${ }^{63}$ in je združevala takratne somišljenike, ki so poudarjali pomen sodelovanja vseh akterjev v vzgojnem procesu.

Med množične odzive prakse pa lahko prištejemo tudi program Korak za korakom, ki je v devetdesetih letih močno zaznamoval vse države v Srednji, Jugovzhodni, Severni Evropi ter vse bivše republike Sovjetske Zveze, Mongolijo in Haiti, kasneje pa je svoje ideje poglabljal in širil tudi v druge države. Pobudo programa, ki bo temeljil na demokratičnih vrednotah in sodobnih spoznanjih na področju predšolske vzgoje, je podal slavni pedagog Fraser Mustard in z njo navdušil Georga Sorosa, ki je program v začetnih letih v celoti financiral. Ciljno je program naravnan na zagotavljanje enakosti in dostopnosti kvalitetnih programov za vse otroke ter na participacijo staršev in skupnosti v zagotavljanje kakovostne vzgoje in izobraževanja za vse. ${ }^{64}$ Program je zanesljivo močno vplival na procese posodabljanja $\mathrm{v}$ vseh državah v tranziciji, med drugim tudi pri nas.

V Sloveniji je leta 1980 je nastal Vzgojni program za vzgojo in varstvo predšolskih otrok, ki se je sicer skušal približati razvoju predšolske vzgoje v svetu, vendar je hkrati odražal stanje tega področja v sedemdesetih letih. Ta trend je bil še zlasti prisoten pri uresničevanju tega programa v praksi, ki je bil odtujen od otroka in prilagojen predvsem zunanjim zahtevam. Kot reakcija na takšno stanje so se začele pojavljati zahteve po »vrtcu po

\footnotetext{
${ }^{61}$ Lilian G. Katz, Five perspectives on quality in early childhood programs, Urbana, Illinois: ERIC Clearinghouse on Elementary and Early Childhood Education, ERIC Document Reproduction Service No. ED-351-148, 1993.

${ }^{62}$ Šalva A. Amonašvili, Zdravstvujte djeti, Moskva 1983.

${ }^{63}$ Š. A. Amonašvili, n. d.

${ }^{64}$ Tatjana Vonta, Kazalci kvalitete organizirane predšolske vzgoje (doktorska disertacija), Ljubljana 2005.
} 
meri otrok«. V praksi pa nastajajo bolj ali manj strokovno načrtovane in preverjene novosti.

Globalne spremembe v Sloveniji, kot so oblikovanje samostojne države, večstrankarski politični sistem, nova ustava, prepoznanje pluralizma vrednostnih sistemov v začetku devetdesetih let, pa so terjale tudi korenite spremembe na področju vzgoje in izobraževanja in so podrobneje opredeljene v Beli knjigi o vzgoji in izobraževanju v Republiki Sloveniji. ${ }^{65} \mathrm{Ob}$ novi zakonodaji ${ }^{66}$ ter izhodiščih, načelih in ciljih vsebinske prenove celotnega sistema vzgoje in izobraževanja ${ }^{67}$ smo leta 1999 dobili tudi Kurikulum za vrtce. ${ }^{68}$ Njegov namen je predvsem:

- omogočiti odprte in fleksibilne programe,

- ponuditi pestrejšo ponudbo na vseh področjih dejavnosti vrtca,

- doseči uravnoteženost različnih področij dejavnosti,

- večje upoštevanje individualnosti, drugačnosti in izbire,

- ustvarjanje pogojev za izražanje in osveščanje skupinskih razlik,

- upoštevanje zasebnosti in intimnosti otrok,

- dvig kakovosti interakcij v vrtcu,

- drugačna časovna razporeditev dejavnosti v vrtcu

- omogočanje avtonomije in strokovne odgovornost delavcev v vrtcu,

- povečanje vloge evalvacije,

- izboljšanje informiranosti in sodelovanja s starši.

Kurikulum temelji na šestnajstih načelih, ki na nek način opredeljujejo pristope uresničevanja zastavljenih ciljev na različnih področjih dejavnosti (gibanje, jezik, umetnost, družba, narava, matematika) ter delovanja vrtca v celoti. Hkrati pa kurikulum ponuja tudi primere dejavnosti po posameznih področjih dejavnosti za mlajšo in starejšo starostno skupino v vrtcu. $S$ tem dokumentom smo na nek način v naš kontekst vnesli osnove sodobnih teoretskih pogledov na otroštvo. Relativno odprt koncept predšolske vzgoje v vrtcu, ki gradi na sodobnih načelih predšolske vzgoje, predvideva strokovno avtonomnost in odgovornost strokovnega osebja v vrtcu. Prav avtonomnost in odgovornost strokovnega osebja za lastne odločitve, ki jih izvaja v praksi in jih hkrati zna osmisliti, zahteva stalno profesionalno rast, sis-

\footnotetext{
${ }^{65}$ Ministrstvo za šolstvo in šport, Bela knjiga o vzgoji in izobraževanju v Republiki Sloveniji, Ljubljana 1995.

${ }^{66}$ Zakon o vrtcih, Ljubljana 1996.

${ }^{67}$ Izhodišca kurikularne prenove, Ljubljana 1996.

${ }^{68}$ Ministrstvo za šolstvo in šport, Kurikulum za vrtce, Ljubljana 1999.
} 
tem evalvacije tega, kar se v praksi v resnici dogaja, ustrezno klimo za spreminjanje in zagotavljanje kakovosti v instituciji ter zunanjo strokovno pomoč, v kolikor jo potrebujejo.

Ob tem je seveda potrebno poudariti tudi dejstvo, da je organizirana predšolska vzgoja pri nas $\mathrm{v}$ procesih tranzicije hkrati s spremembami delovanja na nivoju procesa celo uspela povečati vključenost otrok v organizirano predšolsko vzgojo. 


\section{Sodobno}

razumevanje

kakovosti v

organizirani

predšolski

vzgoji

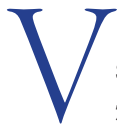

sodobnih družbenih tokovih je tudi na področju vzgoje in izobraževanja eden od osrednjih pojmov, ki predstavljajo sodobne izzive, pojem kakovosti. Pojem kakovosti ponuja izzive tako na filozofskem kot na povsem praktičnem nivoju. Tudi ob vprašanju kakovosti se namreč še vedno srečujemo z vprašanji, kaj je kakovost, kaj je kakovost $\mathrm{v}$ različnih družbenih kontekstih, kaj, kdo in zakaj jo določa, kdo in zakaj se zanjo zanima, kdo, zakaj in kako jo ugotavlja, kako in zakaj jo spreminjati ipd. Zaradi kompleksnosti tega vprašanja enoznačnega odgovora seveda ni mogoče dobiti, se pa danes vse bolj zavedamo različnih kontekstualnih vplivov, ki osvetljujejo ta vprašanja v vsakem konkretnem primeru.

Pojem kakovosti se je na področju vzgoje in izobraževanja pojavil nekoliko kasneje kot na drugih področjih človekove dejavnosti; morda tudi zato, ker ga je prav na našem področju težje definirati. Razviti svet se je začel intenzivneje teoretično pa tudi praktično ukvarjati s kakovostjo sredi šestdesetih let. Na naše področje je pojem prišel iz industrije in podjetništva, vendar šele nekako v osemdesetih letih prejšnjega stoletja. To pa seveda še ne pomeni, da vse dotlej o tem pojmu na našem področju ni bilo govora. Pogled na to, kaj je v vzgoji in izobraževanju dobrega, se je seveda tekom zgodovine tega področja spreminjal. Medvešl meni, da so bile te spremembe pogojene s spreminjanjem pogleda na šolo, vzgojitelja in otroka. Kakovost se je kazala v drugačnih pojavnih oblikah, prav tako pa smo ji namenjali veliko manj pozornosti. Medveš poudarja, da je kakovost danes postala eden od osrednjih pojmov sodobnega življenja, predvsem v razvitem svetu. Kakovost

${ }^{1}$ Zdenko Medveš, Kakovost v šoli, Sodobna pedagogika 51/4 (2000). 
»dobiva univerzalni pomen in naravo, kar pomeni, da preprosto ni več področja, na katerem premislek o kakovosti ne bi bil pomemben «. ${ }^{2} \mathrm{Na}$ pojav kakovosti je zanesljivo vplival tehnološki razvoj, množica dobrin v našem vsakodnevnem življenju, odpiranje trgov, pretok informacij ipd. V idealnih razmerah bi lahko trdili tudi to, da je z naraščanjem razvoja naraščala avtonomnost človeka kot uporabnika tega razvoja. Zanesljivo pa lahko trdimo, da ima človek danes zaradi vse večje ponudbe na »tržišču « vse več možnosti izbiranja in samostojnega odločanja. Zato je bil pojav preusmeritve svetovne javnosti v razvitem svetu na kakovost povsem normalen, če so želeli ohraniti svoje uporabnike. Zanimanje za kakovost na področju vzgoje in izobraževanja je posledica oblikovanja novih paradigem, ki so se začele intenzivneje uveljavljati na našem področju kot posledica razvoja znanstvenih disciplin, ki se ukvarjajo z vzgojo in izobraževanjem, njihovega povezovanja, spoznanj, ki smo jih prenesli iz drugih znanosti, in ki jih doslej nismo povezovali z našim področjem ter hkrati posledica sprememb v družbi, ki zahtevajo stalno ustvarjalno prilagajanje vzgojno-izobraževalnih institucij nastalim razmeram in potrebam sedanjosti in prihodnosti.

$\mathrm{Na}$ področju vzgoje in izobraževanja se je po mnenju Medveša ${ }^{3}$ pojem kakovosti razvijal premosorazmerno $\mathrm{z}$ avtonomnostjo vzgojno-izobraževalnih institucij in pedagogov. To pomeni, da je kakovost tem bolj pomembna, čim bolj je pedagog prepuščen sam sebi, da v množici ponujenih modelov, pristopov, metod, ciljev izbere in uresničuje tiste, ki bodo rodili najboljše rezultate. K temu bi lahko dodali tudi spoznanje, da je kakovost vse bolj pomembna, čim bolj je vrtec (vzgojno-izobraževalna institucija) odprt za starše in druge zainteresirane posameznike in skupine v okolju. Preglednost in odprtost tega, kar se v vzgojno-izobraževalni instituciji dogaja, posredno in neposredno vpliva na kakovost tega procesa. Dokler je vzgojitelj sam zaprt v svoj oddelek, neke velike potrebe za spreminjanje tega, kar počne, ne vidi, razen tiste, ki prihaja s strani obvez do države. Če je nekoč skrb za kakovost v vzgoji in izobraževanju v celoti prevzemala državna šolska inšpekcija, je $v$ procesih demokratizacije ta razpršena na različne dejavnike $\mathrm{v}$ instituciji in izven nje.

Pojmovanje kakovosti oziroma njeno definiranje je zelo različno, prav tako različni pa so tudi kriteriji, po katerih merimo in opredeljujemo kakovost posameznih šol. Kroflič meni, ${ }^{4}$ da je kakovost v filozofskem smislu

${ }^{2}$ N.d., 10.

${ }^{3}$ N. d.

${ }^{4}$ Robi Kroflič, Temeljne predpostavke, načela in cilji kurikula za vrtce, v: L. Marjanovič Umek, Otrok v vrtcu. Priročnik h kurikulumu za vrtce, Maribor 2001. 
kategorija, ki je ne moremo opredeliti z merljivimi atributi. Zato je tudi nemogoče opredeliti absolutni kriterij kakovosti oziroma o njej lahko sklepamo le posredno na osnovi določenih merljivih lastnosti vhodnih, procesnih in izhodnih postavk oziroma kazalcev. Čeprav enotne definicije kakovosti ni, pa lahko trdimo, da se zahtevi po kakovosti, njenemu zagotavljanju in razvijanju ni mogoče izogniti prav zaradi potrebe po stalnem prilagajanju spremembam v okolju. ${ }^{5} \mathrm{~V}$ tem procesu potovanja skozi spremembe nastopajo tudi tako imenovani kritični trenutki, ko po določenem obdobju uvajanja spremembe pride do krize. Krizo v strokovni literaturi poimenujejo »implementacijski padec«, označuje pa tisti trenutek, ko je pri tem potovanju v spremembah potrebno ponovno osredotočiti pozornost na cilje in rešitve, h katerim » potujemo $\ll{ }^{6}{ }^{6}$

Ko povzema motive sodobnih razvitih družb za to, da spodbujajo projekte kakovosti, Medveš med njimi navaja naslednje:?

- povečano skrb za procese integracije proti tradicionalnim oblikam segregacije in zunanje diferenciacije;

- tekmovalnost oziroma konkurenco kot gonilno silo uspešnega vključevanja v dogajanja na svetovnem trgu;

- povečan interes javnosti za šolo;

- demokratizacijo, ki prinaša povečano željo in zahtevo po večji participaciji in soodločanju vseh udeležencev v procesih soodločanja in odločanja o vseh segmentih njihovega življenja, torej tudi življenja v šoli ter povečan interes šol za ustrezno metodologijo, s katero lahko svoje delo oziroma kakovost predstavi javnosti in se ustrezno zavaruje pred subjektivnimi očitki;

- novo kulturo pouka, v kateri mora vzgojitelj spreminjati oblike poučevanja in reflektirati svoje delo s stališča otrok;

- nove cilje, ki nastajajo ob hitrem razvoju znanosti in poudarjajo predvsem razvijanje tistih sposobnosti, ki omogočajo iskati znanje, z njim komunicirati in ga uporabljati in razvijati v neznanih in drugačnih situacijah; za njihovo uresničevanje pa je potrebno življenje v vzgojno-izobraževalni instituciji stalno evalvirati in razvijati;

\footnotetext{
${ }^{5}$ Janez Bečaj, Doseganje popolne kakovosti - cilj za naslednjo petletko? Kakovost preduniverzitetnega izobraževanja, Ljubljana 1996.

${ }^{6}$ Robby Champion, Tools for Change workshop. National Staff Development Council. Cost, 2uality and Child Outcomes Study Team. Cost, Quality, and Child Outcomes in Child Care Centres: Public report, Denver 1993; Michael Fullan, Leading in a Culture of Change, NSDC Annual Conference (uvodni referat), Boston 2002.

${ }^{7}$ Z. Medveš, n. d., 13.
} 
- pluralizem vrednostne naravnanosti sodobnega človeka, ki ga institucija rešuje ob komunikaciji o vrednotah ter reševanju konfliktnih situacij ob upoštevanju pravne osnove ter otrokovih pravic.

Potreba po kakovosti na področju vzgoje in izobraževanja je torej jasno opredeljena in kaže izrazite potrebe po spremembah v praksi. Ob dosedanjih izkušnjah z reformami je dozorelo spoznanje, da so spremembe, ki jih želimo uvajati v prakso, mnogo boljše, trajnejše in kvalitetnejše, če v procesu spreminjanja aktivno sodelujejo tisti, ki naj bi spremembo izvajali. Gre za znano dilemo relativne neuspešnosti spreminjanja od zgoraj navzdol, ki odseva hierarhične odnose $\mathrm{v}$ stroki, podcenjevanje prakse in nerazumevanje procesa učenja oziroma spreminjanja pri odraslih oziroma v instituciji. Dolgotrajno sposobnost spreminjanja vrtcev lahko dosežemo le, če se v proces spreminjanja vrtca aktivno vključimo. ${ }^{8}$

Ena od konkretnih potreb pri opredeljevanju kvalitetnega pedagoškega procesa pa je sprememba paradigme, ki prehaja od skrbi za kakovostno poučevanje v skrb za spodbujanje kakovostnega učenja. Gre za premik iz transmisijskega $\mathrm{k}$ interakcijskemu pojmovanju učenja ter za ustrezne spremembe v pojmovanjih učenja, znanja, vloge vzgojitelja oziroma vzgojitelja in otroka oziroma otroka in za ugotavljanje pogojev, pod katerimi se kakovostno učenje pojavlja.

Pranckuniene, Vildžiuniene, Walsh navajajo tri vrste značilnosti sodobnega pojmovanja kvalitetne vzgojno-izobraževalne institucije, in sicer: ${ }^{9}$

1) Skupno poslanstvo oziroma cilji, ki jim sledijo. Skupno poslanstvo lahko dosežejo le na osnovi jasnih ciljev, sodelovanja pri izmenjavi vrednot in prepričanj ter soudeležbe pri vodenju in sprejemanju odločitev.

2) Ustrezna klima oziroma kultura, ki spodbuja učenje. Za oblikovanje ustrezne klime oziroma kulture, ki je značilna za uspešne institucije, je pomembno, da imajo vsi (otroci, starši in zaposleni) možnost participacije in soudeležbe pri svojem učenju in učenju drugih in da za svoje učenje sprejemajo odgovornost. Ustrezno klimo zagotavlja ustrezno fizično okolje, ki mora na eni strani zagotavljati občutek varnosti, na drugi strani pa nuditi dovolj spodbud za aktivno učenje v različnih situacijah. Ustrezno klimo tvorijo priznanja in izzivi, pozitivno interakcijo med vsemi udeleženci, aktivno vključevanje in podporo staršev ter skupnosti.

\footnotetext{
${ }^{8}$ M. Fullan, The new meaning of educational change, New York 1991.

${ }^{9}$ E. Pranckuniene, M. Vildžiuniene, K. B. Walsh, Step by Step to School Improvement, Workshop materials, ISSA 2002.
} 
3) Poudarek je na učenju vseh - ne le otrok! To pa pomeni, da smo usmerjeni k vzgojnemu procesu, h kurikulumu, razvijanju kolegialnosti na vseh nivojih, podpiramo strokovni razvoj in strokovno odgovornost izvajalcev, imamo visoka pričakovanja do sebe in do drugih in redno spremljamo svoj napredek in napredek otrok.

V vseh prizadevanjih, ki se vrtijo okrog kakovosti, gre pravzaprav predvsem za spremembo znotraj institucije, znotraj oddelka, spremembo pri vseh, ki so v te procese vpeti. Ker pa je končni uspeh odvisen od vseh udeležencev $\mathrm{v}$ tem procesu in ker različni udeleženci različno hitro ali počasi sprejemajo spremembe in se spreminjajo, je ta proces izjemno kompleksen in ga ne moremo ocenjevati zgolj po zunanjih kriterijih.

Ob tem se seveda pojavi več vprašanj, med katerimi je zelo pomembno vprašanje, komu naj bi bila kakovost namenjena in kakšna naj bi bila. Schlechty poudarja, ${ }^{10}$ da v sodobni družbi opredeljuje kakovost to, kar uporabnik želi in potrebuje. Tako je določena usluga visoke kakovosti, če ima kakovosti, ki jih želijo in cenijo uporabniki, in nima kvalitet, ki niso zaželene in jih ne cenijo. Rezultat teh zaželenih in nezaželenih, cenjenih in necenjenih kvalitet $\mathrm{v}$ uslugah vodi potemtakem v domnevo, da je mogoče kakovost najbolje opredeliti in opisati kot variablo na določenem kontinuumu. Vendar temu ni tako; kakovost obstaja, če je usluga prilagojena potrebam uporabnika ${ }^{11}$ ali pa ne obstaja.

In kdo je v tem primeru uporabnik? Na področju vzgoje in izobraževanja jih je kar nekaj, predvsem so to otroci (danes in zdaj, pa tudi kasneje v svojem življenju), njihovi starši in širša skupnost.

\section{Kakovost predšolske vzgoje}

Pojem kakovosti tudi na področju organizirane predšolske vzgoje ne gre gledati drugače, kot na celotnem področju vzgoje in izobraževanja. Organizirana predšolska vzgoja je zapleten sistem, v katerega je vključeno veliko število posameznikov in interesnih skupin. Vsak od njih lahko na kakovost gleda drugače. Različnost se kaže v kulturnih prepričanjih in pričakovanjih v odnosu do organizirane predšolske vzgoje: odvisna je od njihovega gledanja in pojmovanja otroštva, kulturnih vzorcev, vrednot, politike ter drugih socialnih dejavnikov v družbi. Po drugi strani pa lahko ugotovimo, da je na teoretskem nivoju te različnosti veliko manj, čeprav gradi predvsem na zahodno orientirani pedagoški znanosti in tradiciji. Kakovosti tudi na tem področju ne gre pojmovati kot univerzalne, hkrati pa tudi

\footnotetext{
${ }^{10}$ Phillip C. Schlechty, Inventing Better Schools, San Francisco 2001, 55.

${ }^{11}$ Philip B. Crosby, Quality is free: The art of making quality certain, New York 1979.
} 
ne kot povsem samovoljne kategorije. Seveda pa po drugi strani tudi ne gre vsega prepuščati stihiji oziroma relativizmu, ampak velja razmišljati predvsem o kontekstualnemu okviru za postavitev določenega standarda. Relativizem je le začetek procesa, nikakor pa ni njen konec, pravi Woodhead. ${ }^{12}$ $\mathrm{V}$ procesu odločanja o standardih pa ne smemo mimo nekaterih bolj univerzalno definiranih kriterijev, ki naj bi jih upoštevali, kot so otrokove biološke potrebe in socialne potrebe ter pravice otrok. $V$ ta sklop po mnenju Woodheada sodijo tudi univerzalni principi razvoja in učenja, ki pa naj bi bili združljivi s socialnimi razmerami, vrednotami in aspiracijami na nacionalnem, regionalnem, lokalnem, družinskem nivoju ter na nivoju organizirane predšolske vzgoje oziroma programa. Avtor se zavzema za to, da je potrebno oblikovati presoje, kriterije in standarde, o katerih se moramo dogovoriti. Vendar hkrati opozarja, da so presoje kakovosti odraz zapletenega sistema prepričanj, znanja, vrednot, kulture, družbenega konteksta in pogledov na otroštvo, zato je na kakovost potrebno gledati predvsem s perspektive vsake konkretne institucije. Isti avtor tudi meni, ${ }^{13}$ da si je v procesu dogovarjanja med različnimi subjekti, ki se ukvarjajo s kakovostjo organizirane predšolske vzgoje, potrebno odgovoriti na naslednja tri vprašanja:

- Kdo so zainteresirani posamezniki in skupine za kvalitetno organizirano predšolsko vzgojo? Število teh zainteresiranih skupin in posameznikov je veliko in vsak od njih ima svoje gledanje na kakovost glede na svoje interese, njihovo vlogo, moč in vplivnost. Med njimi so: ravnatelj vrtca, vzgojiteljica, pomočnica vzgojiteljice, starši, predstavniki lokalne skupnosti, strokovnjaki na področju predšolske vzgoje in izobraževanja, politiki, financerji, raziskovalci, strokovna združenja, ki zastopajo interese stroke, predvsem pa otroci.

- Kdo bo občutil koristi od kakovosti? Največkrat se strinjamo, da so to otroci, vendar bi marsikdo k temu prištel tudi starše, učitelje v osnovni šoli, ki sprejmejo mnogo bolj pripravljene otroke, politike in vodstvene strukture na nivoju lokalne skupnosti, ki lahko pridobijo na ugledu ipd. - Kaj naj bi bili kazalci kakovosti? Presoja o kakovosti je povezana s cilji in pričakovanji v odnosu do organizirane predšolske vzgoje oziroma otroštva v celoti. Lahko se osredotočijo na osnovne standarde skrbi za nego in zdravje, vire za igro in učenje; značilnosti odnosov med odraslimi in otro$\mathrm{ki}$, odnose med vzgojitelji in starši, fleksibilnost v odnosu do potreb star-

\footnotetext{
${ }^{12}$ Martin Woodhead, In search of the rainbow. Pathways to quality in large-scale programs for young disadvantage children. Early Childhood Development, Practice and Reflections 10, Hague 1996, 46.

${ }^{13}$ M. Woodhead, n. d., 39.
} 
šev ipd. Pri tem pa Woodhead te indikatorje deli v vhodne, procesne in izhodne.

Nadalje predlaga, da lahko na ta tri vprašanja gledamo tridimenzionalno in tako upoštevamo različne poglede na organizirano predšolsko vzgojo. Na ta problem je že leta 1993 opozorila Katzova, ${ }^{14}$ ko je opredeljevala različne perspektive, iz katerih lahko gledamo na kakovost organizirane predšolske vzgoje. Tako pojmovanje kakovosti je seveda pogojeno $\mathrm{z}$ demokratizacijo in decentralizacijo vzgoje in izobraževanja nasploh ter vse večjim vključevanjem različnih interesnih skupin in posameznikov v oblikovanje in sprejemanje odločitev na tem področju. Moč teh posameznikov in skupin seveda v praksi še zdaleč ni izenačena, prav pa je, da ta postane bolj jasna in da se daje glas tudi tistim, ki ga niso imeli ali pa ga niso mogli izraziti. Obstaja pa nevarnost, da se vse to uresničuje le na formalni ravni.

Eden od načinov, kako definirati kakovost organizirane predšolske vzgoje, je tudi ugotavljanje, do kolikšne mere ustreza potrebam otrok. Obstaja pa razlika med osnovnimi potrebami, ki jih lahko opazujemo ter socialnimi potrebami, ki pa so bolj vezane na vsakokratno kulturo, v kateri otrok živi. Prav zato osnovo razprav o kakovosti vse bolj tvorijo otrokove pravice. Pri tem pa je seveda potrebno osnovne teoretične principe o otrokovih pravicah interpretirati z vidika političnega, ekonomskega, socialnega, religioznega in kulturnega konteksta in jih prevesti in razumeti na nivoju prakse.

Kakovost lahko presojamo tudi z vidika poslanstva, ki ga organizirana predšolska vzgoja opravlja. V poslanstvu namreč izražamo namen oziroma cilje te dejavnosti in opredelimo, komu je dejavnost namenjena, upoštevamo torej tudi uporabnike. Organizirana predšolska vzgoja gradi svoje poslanstvo na otrocih, starših, pa tudi na širši skupnosti. Zato ni odveč vprašanje, do kolikšne mere je organizirana predšolska vzgoja prilagojena temu poslanstvu oziroma do kolikšne mere ustreza namenu.

$\mathrm{V}$ organizirani predšolski vzgoji so njeni neposredni uporabniki sicer otroci, vendar posredno tudi starši in širše družbeno okolje. In če starši in širše družbeno okolje najbolj cenijo znanje, kognitivne sposobnosti, trenutne sposobnosti, ki otroka pripravijo za šolsko učenje, bodo merili kakovost predvsem po tem, ali so otroci dovolj zaposleni in ali imajo dovolj dejavnosti, ki zahtevajo njihovo intelektualno aktivnost. Do kolikšne mere

\footnotetext{
${ }^{14}$ Lilian G. Katz, Five perspectives on quality in early childhood programs, Urbana, Illinois: ERIC Clearinghouse on Elementary and Early Childhood Education, ERIC Document Reproduction Service No. ED-351-148, 1993.
} 
torej vrtec prilagoditi željam in potrebam uporabnikov in katerim uporabnikom: otrokom, njihovim staršem ali širši skupnosti?

Ne glede na vse druge značilnosti vrtca menimo, da v primeru, če otroci ne bodo hoteli ali ne bodo zmogli početi tega, kar se od njih zahteva in pričakuje, to ni kakovosten vrtec. Torej je vrtec potrebno prilagoditi otrokom, njihovim razvojnim, individualnim in kulturnim značilnostim, potrebam in pravicam. Modrost prakse se združuje v tako imenovani »razvojno primerni praksi«. Upoštevanje teh vodil pa še ne pomeni, da se zavzemamo za drugo skrajnost, $v$ kateri zgolj otroci odločajo o tem, kaj je vredno početi in se učiti. Vrtci naj bi sicer bili osredotočeni na otroka, na njegove potrebe in pravice, kar pa še ne pomeni, da vrtce vodijo otroci. Osredotočenost na otroka predvsem pomeni, da vrtec svoje dejavnosti načrtuje, izvaja in evalvira $\mathrm{z}$ vidika koristi in pravic za vse otroke.

Kakovosti in uspešnosti predšolskih programov tudi ne velja presojati le z vidika razvijanja enostavnih kognitivnih sposobnosti. Kurikulum mora biti ekspliciten glede otrokovega celostnega razvoja in razvijanja različnih dimenzij njegove osebnosti, biti pa mora tudi bolj učno procesno orientiran. Otroku mora pomagati razviti strategije, s katerimi bo premagoval stresne situacije in neuspehe pa tudi vztrajnost. $\mathrm{V}$ tem kontekstu je v predšolski edukaciji nadvse pomembna tudi komunikacija in interakcija med otrokom in odraslim ter otrokom in vrstniki. $V$ čem se vse to razlikuje od klasičnih konstruktivističnih kurikulov iz šestdesetih let? Tudi klasični konstruktivistični kurikuli temeljijo na otrokovem raziskovanju fizičnega okolja, vendar interakciji otroka z odraslimi in vrstniki v teh kurikulih ne posvečajo veliko pozornosti. Le-ta najde svoje mesto predvsem pri reševanju konfliktov. Vloga odraslih v tem procesu je minimalna. Socialni konstruktivizem pa poudarja prav te elemente v procesu učenja.

V svojem razvoju je organizirana predšolska vzgoja izdelala celosten pristop, ki vključuje v partnerstvo družino, vrtec in družbo. Partnerstvo družine in institucije pri prenosu vrednot in znanja poudarjajo številne teorije o predšolski vzgoji in izobraževanju. Pri tem je vse bolj prisotno spoznanje, da je to, »kar naj bi otroci delali in bili«, in predstavlja osrednje vodilo vzgajanja doma in $\mathrm{v}$ instituciji, hkrati tesno povezano s konceptom kulturnega spoštovanja. Vse bolj se poudarja pomen otrokovega samospoštovanja pri učenju, ki je omogočeno, če se zavedamo in spoštujemo kulturno različnost in njegovo kulturno dediščino. Koncept kulturnega spoštovanja in primernosti ter participacije družine zato postajajo temeljne kategorije kvalitetnih programov. 
Ob tem pa se je končno utrdilo tudi spoznanje, da se predšolski otroci močno razlikujejo od starejših otrok in odraslih in da potrebujejo posebno pozornost. Spoznanja različnih teoretikov danes že omogočajo drugačno razumevanje otrokovega učenja in učnega okolja, ki predstavlja kontekst, v katerem lahko uresničimo potrebe današnjega otroka in državljana v 21.stoletju. Vemo, da je otrokova osebna izkušnja življenjskega pomena v razvoju pojmov, ${ }^{15} \mathrm{da}$ je učenje medsebojno delovanje med procesom asimilacije in akomodacije, da je senzorno in temelji na tem, kar je tukaj in sedaj, ${ }^{16} \mathrm{da}$ otroci gradijo in razvijejo nove pojme $s$ primerjanjem prejšnjega znanja z novimi izkušnjami in da je proces učenja gibanje od konkretnega osebnega razumevanja $\mathrm{k}$ vse bolj konvencionalnemu razumevanju. ${ }^{17} \mathrm{Ra}$ zvoj jezika in mišljenja sta močno odvisna od socialnih in kulturnih vplivov. ${ }^{18}$ Vemo, da se nove informacije, ki so povezane z življenjskimi dogodki in so smiselne, vsakodnevno osvajajo na temelju pomembnosti, kompleksnosti in visoko socialno-interaktivno naravo izkušnje. ${ }^{19}$ Vemo, da sta za učenje življenjskega pomena zadovoljitev bioloških potreb in psihološka varnost. ${ }^{20}$ Prav tako vemo, da otroci, medtem ko raziskujejo svoje socialno okolje, pridobivajo sposobnosti jezikovne komunikacije. ${ }^{21}$ Vemo tudi to, da mora biti učenje za otroke osebno pomembno in smiselno. ${ }^{22}$ Vemo, da lahko razvojno in individualno primerno prakso v pogojih organizirane predšolske vzgoje ${ }^{23}$ dosežemo z odprtimi strukturami (transformacijskim kurikulom) in individualizacijo na različnih nivojih ${ }^{24}$ in če otroka z njegovim sociokulturnim kontekstom obdržimo na osrednjem mestu, v središču pozornosti. ${ }^{25}$ Novejša nevrološka spoznanja o procesu učenja pa potrjujejo tudi potrebo po učenju, ki izhaja iz celostnih, integriranih dejavnosti. ${ }^{26}$

\footnotetext{
${ }^{15}$ J. Dewey, Democracy and education, New York 1916/1985.

${ }^{16}$ J. Piaget, Six psychological studies, New York 1968.

${ }^{17}$ Rheta Devries, Lawrence Kohlberg, Constructivist early education: Overview and comparation with other programs, Washington D. C. 1990.

${ }^{18}$ L. S. Vigotsky, Sobranije sočinjenij, I-II, Moskva 1982.

${ }^{19}$ L. S. Vigotsky, Mind in Society, Cambridge, Massachusetts 1978; Sobranije sočinjenij, Vdvuh tomah, Moskva 1982; Š. A. Amonašvili, V̌̌kolu š̌esti let, Moskva 1986.

${ }^{20}$ A. H. Maslow, The farther reaches of human nature, New York 1973.

${ }^{21}$ Jerome Bruner, Actual minds, possible worlds, Cambridge 1986.

${ }^{22}$ Carl Rogers, Freedom to Learn: A View of What Education Might Become, 4th ed., Columbus, Ohio 1974.

${ }^{23} \mathrm{~S}$. Bredekamp, Developmentally appropriate practice in early childhood programs serving children from birth through age 8, Washington D. C. 1987.

${ }^{24}$ S. Bredekamp, T. Rosegrant, Reaching potentials: Appropriate curriculum and assessment for young children, vol. 1, Washington D. C. 1993.

${ }^{25}$ Phillip C. Schlechty, Inventing Better Schools, San Francisco 2001.

${ }^{26}$ Leslie A. Hart, Human brain and human learning, New York 1986; R. N. Caine, G. Caine, Making connections. Teaching and the human brain, New York 1994; Lilian Katz, Sylvia C.
} 


\section{Kakovost vrtca $\mathrm{z}$ vidika otrok}

Vrtec torej ni namenjen le temu, da bi otroci realizirali bazične potrebe, kot so preživetje, moč, ljubezen, radost in svoboda, ${ }^{27}$ ampak uresničuje tudi svoje pravice ter potrebe staršev in družbe. In če želi biti vrtec pri svojem delu uspešen in kakovosten, mora organizirati življenje, ki ga ponuja otrokom in odraslim, ki se v tej instituciji srečujejo, na tako privlačen način, da otroci in odrasli vanj radi prihajajo, vztrajajo pri novih izzivih (učenju), čeprav se jim to zdi težko in zahtevno, in na koncu dosežejo uspeh. Ob tem pa je seveda pomembno tudi to, da je vse, kar se otroci in odrasli naučijo $\mathrm{v}$ tem procesu, prav tako pomembno kot sam rezultat tega početja. Odrasli in otroci se najbolje učijo, če želijo nekaj doseči, če so notranje motivirani za to, kar pa ni mogoče brez razvijanja novih spretnosti, sposobnosti, razumevanja, vedenja in navad.

V tem okviru je pomemben kazalec kakovosti vrtca to, kar se otrokom dogaja kot rezultat dejavnosti, ki jih omogoča vrtec. Kvalitetno delo vrtca je tudi tisto, ob katerem otroci razvijajo sposobnosti, spretnosti, razumevanje, vedenje ter razmišljanje, ki ga odrasli v družbi cenijo. V skladu s to trditvijo je kvalitetno delo vrtca odvisno od ciljev, ki jih vrtec zna prevajati in prenesti v življenje. Otroci sicer niso odrasli, ampak kakovost izkušenj, ki si jih bodo pridobili v vrtcu, bo močno odločala o tem, kakšni bodo v odraslosti. Otroci ne vedo, česa se morajo naučiti, ampak na nek način vedo in čutijo, za kaj so pripravljeni, sposobni in kaj se želijo učiti.

Da pa bi vrtec v svoje življenje vgradil kakovost, mora vedeti tudi to, kaj otroci in starši v določenem družbenem kontekstu cenijo in v kaj verjamejo, da bo zadovoljilo njihove pravice in potrebe. Vrtec je torej nekaj, kar služi otrokom in njihovim potrebam, pa tudi nekaj, kar hkrati služi družbi in njeni prihodnosti. Do kakovosti pa pride, kadar se oboje optimalno poveže.

$\mathrm{Na}$ nivoju otrok je seveda najbolj pomembno dejstvo, da smo prepričani $\mathrm{v}$ to, da organizirana predšolska vzgoja zadovoljuje otrokove pravice in potrebe ter da ima pozitivne učinke na otrokov trenutni in dolgoročni razvoj. Kot taka si lahko zasluži oznako kakovosti z vidika otrok. Uvid v učinke organizirane predšolske vzgoje na otrokov razvoj je torej nujen predpogoj za razumevanje poslanstva te dejavnosti.

Chard, Engaging Children's Minds: The Project Approach, New York 1995; H. Gardner, Developing the spectrum of human intelligence, Harvard Educational Review 57/2 (1987), 187-193; H. Gardner, The unschooled mind, New York 1991; H. Gardner, Frames of mind: The theory of multiple intelligence, New York 1983.

${ }^{27}$ William Glasser, The quality school: Managing students without coercion, New York 1990. 
V nadaljevanju bomo skušali razmišljati o kakovosti v vrtcu še z vidika staršev in širše družbe, čeprav se tudi doslej tem kategorijam nismo mogli izogniti zaradi povezanosti in soodvisnosti med njimi. Še prej pa bomo pogledali, kako opredeljujejo vpliv kakovosti v organizirani predšolski vzgoji različne raziskave.

\section{Kakšen je vpliv kakovosti organizirane predšolske vzgoje na otrokov razvoj}

Rezultati o učinkih institucionalne predšolske vzgoje na otrokov razvoj so prišli v ospredje zanimanja tako, da so se začeli spraševati, ali je ta za predšolske otroke dobra ali slaba, zlasti za mlajše predšolske otroke. Sylva in Wiltshire ${ }^{28}$ ugotavljata, da je bilo še v začetku osemdesetih let prejšnjega stoletja ugotovljenih zelo malo učinkov na otrokov kognitivni, socialni ali emocionalni razvoj. Večina raziskav $\mathrm{v}$ šestdesetih in sedemdesetih letih prejšnjega stoletja se je ukvarjala z vprašanjem ali, kako in v kolikšni meri izpostavljanje otroka zunajdružinski vzgoji škoduje njegovemu razvoju. ${ }^{29}$ Prav tako je večina teh raziskav ugotavljala, da so otroci v pogojih »skupnega varstva « bolj agresivni in oblastni ter nepopustljivi od drugih otrok. Le posamezni avtorji, kot npr. Andersson, ${ }^{30}$ poročajo o pozitivnih učinkih organizirane predšolske vzgoje na otrokov razvoj.

Rezultati raziskav, ki so proučevale učinke organizirane predšolske vzgoje na uspeh v šoli, so pokazali, da ti zbledijo kmalu po otrokovem vstopu v šolo. Tudi raziskave iz sedemdesetih in začetka osemdesetih let prejšnjega stoletja so pokazale, da zgodnji edukacijski programi, ki so bili prvenstveno kompenzacijsko naravnani, niso vplivali na zvišanje IQ vrednosti. Ti rezultati so močno povečali dvome $\mathrm{v}$ vrednost institucionalno organizirane predšolske vzgoje in vlaganje $\mathrm{v}$ to dejavnost. $\mathrm{V}$ vseh teh študijah je bila organizirana predšolska vzgoja razumljena kot »homogen prostor «, čeprav vemo, da znotraj tega pojma lahko srečujemo različne pojavne oblike in kontekste.

Šele nekaj metodološko strožjih raziskav v osemdesetih letih je pokazalo trajnejše učinke predšolske edukacije, ki so veliko bolj pomembni kot sam inteligenčni kvocient. Kasneje so nas mnoge raziskave tudi v našem prosto-

\footnotetext{
${ }^{28}$ Kathy Sylva, Jacqueline Wiltshire, The Impact of Early Learning on Children's Later Development. A review Prepared for RSA Inquiry »Start Right «, European Early Childhood Education Research Journal 1 (1993), 17-41.

${ }^{29}$ Harry McGurk, Marlene Caplan, Eilis Hennessy, Peter Moss, Controversy, Theory and Social Context in Contemporary Day Care Research, Child Psychology Psychiatry 34/1 (1993), 3-23.

${ }^{30}$ Bengt-Erik Andersson, Effects of public day care: a longitudinal study, Child Development 60 (1989), 857-866.
} 
$\mathrm{ru}^{31}$ prepričale, da dobri predšolski programi ne kažejo negativnih vplivov in da otroci iz nižjih socialnih in kulturnih slojev celo pospešijo kognitivni razvoj, če so vanje vključeni. ${ }^{32}$

\section{Študije o učinkih Head Start programov}

Sredi šestdesetih let prejšnjega stoletja je nastal ameriški projekt Head Start. Projekt, ki je potekal pod okriljem tedanjega predsednika Lyndona Johnsona, je predstavljal »vojno napoved proti revščini, ki se ciklično ponavlja znotraj enih in istih struktur ${ }^{33}{ }^{33} \mathrm{~V}$ projektu so predpostavljali, da bi v dveh desetletjih ta ciklus revščine prelomili tako, da bi dvignili socialno in edukativno kompetenco revnih otrok. ${ }^{34}$ Pri načrtovanju programa je bilo eno glavnih vprašanj, kako pomagati revnim otrokom priti do startne linije (za vstop v šolo), ki bo potekala vštric z drugimi otroki.

Raziskovalci so že na začetku projekta močno dvomili v pričakovanja o »izobraževalnem čudežu «, ki bi naj izkoreninil učinke revščine v enem samem letu pred vstopom v šolo. Preprosta evalvacija teh prizadevanj je temeljila na metodologiji, ki je bila zelo enostavna in se je usmerjala predvsem na merjenje in primerjanje rezultatov na testih inteligentnosti pri otrocih, ki so bili deležni teh programov, in pri otrocih, ki tega niso bili deležni. Rezultati začetnih evalvacij so bili sila neugodni. ${ }^{35}$ Osnovni razlog za to pa lahko iščemo tudi v dejstvu, da so se usmerile na merjenje inteligentnosti kot glavnega in najpomembnejšega »proizvoda«. Poleg tega so v teh evalvacijah ugotovili, da začetne prednosti v vrednostih IQ kmalu izginejo, tako da se otroci, ki so bili vključeni v Head Start program, po ugotovljenih lastnostih niso razlikovali od otrok, ki so bili v kontrolnih skupinah.

Mnogo bolj metodološko zahtevne pa so bile sodobne meta analize programov Head Start. Leta 1985 je bila objavljena sinteza raziskovalnih izsledkov o učinkih programov Head Start. ${ }^{36}$ Sinteza je s pomočjo enostavne

\footnotetext{
${ }^{31}$ Ludvik Horvat, Vpliv sistematične predšolske vzgoje na otrokov intelektualni razvoj s psihometričnega in kvalitativno analitičnega aspekta (doktorska disertacija), Ljubljana 1983.

${ }^{32}$ Ellen Gray, Child Care and family functioning: A review, Journal of Child Care 1 (1983), 1516; Judy Rubenstein, The effects of maternal employment on young children, Applied Developmental Psychology 2 (1985), 99-120.

${ }^{33}$ Navedeno po: B. Spodek, P. C. Brown, Curriculum Alternatives in Early Childhood Education: A Historical Perspective, New York 1993.

${ }^{34}$ Edward F. Zigler, Susan Muenchow, How to influence social policy affecting children and families, American Psychologist 39 (1984), 415-420.

${ }^{35}$ Marshall Smith, Joan S. Bissell, The impact of Head Start: The Westinghouse - Ohio Head Start evaluation, Harvard Educational Review 40 (1970), 51-104.

${ }^{36}$ Ruth Hubbell Mckey, Larry Condelli, Harriet Ganson, Bruce Barrett, William McConkey, Margaret C. Plantz, The Impact of Head Start on Children, Families and Communities. Final Re-
} 
meta analize vključila rezultate 210 študij, ki so evalvirale učinke programa Head Start. McKey in njegovi sodelavci pri tem poudarjajo, da so bile študije opravljene na zelo različen način in da je tudi njihova strogost v metodološkem smislu zelo različna, tako da je bilo težko, če že ne skoraj nemogoče, pri nekaterih vprašanjih priti do zaključkov. To so zlasti vprašanja, ki zadevajo sodelovanje in vključevanje staršev v program. Veliko študij ni kontroliralo vhodnih razlik $\mathrm{v}$ sposobnostih otrok, kontrolne skupine niso bile primerljive ipd.

Rezultati te sinteze kažejo, da imajo Head Start programi neposredne učinke na otrokove kognitivne sposobnosti, žal pa se te kognitivne prednosti ne obdržijo dlje kot do drugega leta šolanja. Prav tako lahko iz rezultatov študije ugotovimo, da imajo programi Head Start takojšnje pozitivne učinke na otrokovo samooceno, šolski uspeh, motivacijo in socialno obnašanje. Toda tudi v tem primeru se prednosti, ki so prisotne v začetku, nagibajo k upadanju in izginjanju ob koncu tretjega leta šolanja.

Pri tem velja poudariti, da je veliko raziskovalcev tudi ugotovilo, da so bili v Head Start programe vključeni zlasti otroci iz resno socialno ogroženih družin, ${ }^{37}$ kar je nedvomno vplivalo na dosežene rezultate. Lee, BrooksGunn in Schnur ugotavljajo, ${ }^{38}$ da so bili v Head Start programe v resnici vključeni le otroci iz izrazito revnih in zaostalih okolij, zato so primerjave s tistimi, ki niso bili vključeni v Head Start programe, neupravičene. Avtorji zato menijo, da se vse razprave, povezane z rezultati, lahko omejijo le na primerjavo revnih otrok, ki so obiskovali programe Head Start, in revnih otrok, ki jih niso obiskovali. Prav tako opozarjajo, da dotlej niso primerjali revnih otrok, ki so obiskovali programe Head Start in revnih otrok, ki so bili vključeni v kak drug predšolski program. Raziskovalci so tudi mnenja, da bi zanesljivo vsak temeljitejši intervencijski program povzročil določene pozitivne rezultate pri otrocih.

Konec osemdesetih let prejšnjega stoletja so potekale tudi manjše kontrolne študije učinkov Head Start programa, ki pa so bile metodološko izjemno strogo zastavljene. Tako je Lee s sodelavci ${ }^{39}$ v svoji raziskavi primerjal rezultate 969 otrok iz socialno ogroženih okolij na pred in post-testih.

port of the Head Start Evaluation, Synthesis and Utilisation Project. The Head Start Bureau, Administration for Children, Youth and Families, Washington D. C. 1985.

${ }^{37}$ Victoria Seitz, Laurie H. Rosenbaum, Nancy H. Apfel, Effects of family support intervention: A ten-year follow up, Child Development 56 (1985), 376-391.

${ }^{38}$ Valerie Lee, Jeanne Brooks-Gunn, Elizabeth Schnur, Does head Start Work? A one year follow-up comparison of disadvantaged children attending Head Start, no Preschool and other Preschool Programs, Developmental Psychology 24/2 (1988), 210-222.

${ }^{39}$ V. Lee, J. Brooks-Gunn, E. Schnur, n. d. 
Otroke so razdelili v tri različne primerjalne skupine $\mathrm{z}$ vidika predšolskega okolja:

- na otroke, ki so bili vključeni v Head Start program;

- na otroke, ki so bili vključeni v kak drug predšolski program;

- na otroke, ki niso bili vključeni v noben predšolski program.

Ob vstopu v šolo so na meritvah ugotovili velike razlike med temi skupinami. Otroci, ki so obiskovali program Head Start, so bili pri skoraj vseh meritvah najslabši. Ko pa so nato poskrbeli za izenačitev podvzorcev oziroma vseh treh skupin, se je pokazalo, da so otroci, ki so bili vključeni v programe Head Start, kazali velike pridobitve. Ugotovili so prirastek v merjenju socialnih in kognitivnih funkcij v primerjavi z otroki iz drugih dveh skupin. Raziskava je torej opozorila na učinkovitost Head Start programa $\mathrm{v}$ tem, da je ta pomagal otrokom iz ogroženih okolij ujeti korak z drugimi. Manjšo učinkovitost pa lahko pripisujemo tudi dejstvu, da je bil nivo prikrajšanosti otrok pred vključitvijo v te programe izjemno visok. Študija je tudi pokazala, da so največji napredek naredili otroci Afroameričanov .

Veliko študij, ki so evalvirale kompenzacijske programe, je dokazalo, da je predšolska intervencija zlasti učinkovita za večino ekonomsko ogroženih otrok..$^{40}$ Poleg tega, da so pri tem merili in se orientirali na jezik in splošno inteligenco, so merili tudi druge dimenzije, kot so npr. razvrščanje, motorične spretnosti, splošno socialno in kognitivno funkcioniranje. Prav tako so dokazali, da so ti učinki boljši, če so v program intenzivno vključevali matere.

Izrazit premik v evalvaciji učinkov institucionalne predšolske vzgoje pa predstavljajo rezultati raziskovanja učinkov visoko kvalitetnih predšolskih edukativnih programov v ZDA, ki so potekali po zelo strogih metodoloških kriterijih (velikost vzorca večja od 100 otrok, normalizirani testi sposobnosti, kontrolna in primerjalna skupina, spremljanje otrok pred vstopom v šolo). V študiji je bilo analiziranih enajst programov. Rezultati teh študij kažejo, da je vključevanje otrok v dobre, kognitivno orientirane programe povezano z njihovo kasnejšo šolsko uspešnostjo. Ti otroci so bili manj pogosto potrebni posebne pomoči v teku šolanja in niso zaostajali. Pomembno pa je, da so z longitudinalnimi študijami tudi ugotovili, da imajo ti otroci pri devetnajstih letih starosti višje težnje glede zaposlovanja. ${ }^{41}$

${ }^{40}$ E. F. Zigler, Formal Schooling for four-years-old? American Psychologist 42/3 (1987), 254-260.

${ }^{41}$ Irving Lazar, Richard Darlington, The lasting effects of early education: A report from the Consortium for Longitudinal Studies, Journal of the Society for Research in Child Development 
Med najbolj skrbno evalviranimi programi je tudi Perry Preschool Project, ki je kasneje postal znan pod imenom program High/Scope. Program je bil izpostavljen tridesetletnemu evalviranju in stalno kaže izredne rezultate. ${ }^{42}$ Čeprav začetna prednost v IQ vrednostih pri otrocih, ki so obiskovali ta program, izgine tekom srednje šole, pa se kažejo med njimi in tisti$\mathrm{mi}, \mathrm{ki}$ teh programov niso obiskovali, pomembne razlike. Ugotovili so, da imajo absolventi High/Scope programa pri 27 letih starosti:

- pomembno večji mesečni dohodek;

- med njimi je več lastnikov hiš in lastnikov dveh avtomobilov;

- pomembno višji nivo dokončane šole;

- pomembno nižjo stopnjo socialne pomoči, ki so jo dobivali v zadnjih desetih letih;

- pomembno manj prekrškov, vključno s kriminalnimi dejanji, povezanimi z jemanjem drog ali prodajo drog.

Tudi v raziskavi o dolgoročnih učinkih drugih predšolskih programov ${ }^{43}$ so ugotovili, da prisotnost otrok v predšolskih programih zniža stopnjo njihovega asocialnega vedenja.

Čeprav te študije ne morejo dokazati, da imajo vsi predšolski programi trajne učinke na svoje udeležence, pa so le-te dokazale, da lahko spremenijo tok življenja otrok, zlasti tistih, ki prihajajo iz ogroženih okolij. Ker je raziskovalni pristop $\mathrm{v}$ teh študijah zelo strog $\mathrm{v}$ vzorčenju in $\mathrm{z}$ longitudinalnim spremljanjem, nam ti rezultati nudijo osnovo za sklepanje, da kvalitetna institucionalna predšolska vzgoja povzroča koristne in tudi stroškovno učinkovite daljnosežne učinke.

V raziskavi, ki so jo opravili Schweinhart, Weikart in Larner, ${ }^{44}$ so primerjali učinke treh različnih programov $\mathrm{z}$ različnimi pristopi $\mathrm{k}$ učenju otrok in ugotovili, da vsem otrokom (ne glede na to, kakšen program obiskujejo) pred vstopom v šolo IQ naraste. Sledenje otrokom pri petnajstih letih pa kaže, da so otroci, ki so bili deležni strogo predpisanih predšolskih programov, nefleksibilni in usmerjeni na šolska znanja, imajo pa tudi slab-

47 (1982), 203-223.

${ }^{42}$ John R. Berrueta-Clement, Lawrence J. Schweinhart, William Barnett, Ann S. Epstein, David P. Weikart, Changed Lives: the effects if the Perry Preschool Programme on youths through age 19, Michigan 1984.

${ }^{43}$ Ronald J. Lally, Peter L. Mangione, Alice S. Honig, The Syracuse University family development research program: Long-term impact of an early intervention with low-income children and their families, Parent education as early childhood intervention: Emerging directions 1988.

${ }^{44}$ L. Schweinhart, D. Weikart, Mary B. Larner, Consequences of three preschool curriculum models through age 15, Early Education Research Quarterly (april 1986). 
ši uspeh $\mathrm{v}$ šoli in večjo stopnjo udeležbe $\mathrm{v}$ asocialnem vedenju, kot jo imajo otroci iz ostalih programov. Torej dvig IQ na začetku šolanja še ne pomeni, da bo imel otrok boljši uspeh v šoli. Samo otroci, ki so bili deležni aktivnega učenja v programih pred šolo, imajo koristi od predšolskega izobraževanja, ki se kaže v bolj socialnem obnašanju ter v večji samozavesti $\mathrm{v}$ adolescenci.

Če skušamo povzeti dogajanja na področju raziskovanja organizirane predšolske vzgoje od šestdesetih let prejšnjega stoletja do sredine osemdesetih let, lahko zaključimo, da je bilo opravljeno precejšnje število bolj psihološko usmerjenih raziskav o razvoju otrok, ki so bili vključeni (običajno zaradi zaposlitve staršev) v kakršnokoli obliko organizirane predšolske vzgoje izven družine. Večina raziskav je preverjala, ali takšne izkušnje škodujejo otrokovemu kognitivnemu razvoju ali ne. Zato so primerjali rezultate otrok, ki so bili v organizirani predšolski vzgoji, in tistih, ki niso bili vključeni vanjo. Pri tem pa ne smemo pozabiti, da je bila večina teh raziskav opravljena v okviru Head Start programov, v katere so bili vključeni otroci zelo revnega dela prebivalcev.

Nekako do sredine osemdesetih let so te študije že odražale neko konsistentnost v prikazu učinkov organizirane predšolske vzgoje na otrokov psihični razvoj. Pri tem so ugotovili, da je v primerih, ko je organizirana predšolska vzgoja dobre kakovosti, zelo malo dokazov o tem, da bi škodovala otrokovemu kognitivnemu, socialnemu ali emocionalnemu razvoju. Zanesljivo je bilo mogoče to trditi za otroke, ki so vstopali v organizirano predšolsko vzgojo po tretjem letu starosti, verjetno pa tudi za mlajše otroke, posebej v okoljih, kjer tej dejavnosti namenjajo veliko pozornosti.

Ugotovimo lahko relativno enotnost v pomanjkanju dokazov o negativnih učinkih, ki bi bili značilni za organizirano predšolsko vzgojo, hkrati pa lahko ugotovimo tudi, da omenjene raziskave niso bile izpeljane na slučajnih vzorcih. Uporabljale so majhne numeruse, opravljenih je bilo malo longitudinalnih študij, ${ }^{45}$ ki pa vse kažejo, da visoka kakovost predšolske vzgoje ne vodi $\mathrm{k}$ škodljivim posledicam, ${ }^{46}$ ali pa da ima pozitivne posledice, kot smo že omenili. Še vedno pa je večina študij pojmovala organizirano predšolsko vzgojo kot homogeno polje raziskovanja kljub njegovi raznolikosti v pojavnih oblikah.

\footnotetext{
${ }^{45} \mathrm{~J}$. Rubenstein, The effects of maternal employment on young children, Applied Developmental Psychology 2 (1985), 99-120; Alison K. Clarke-Stewart, The »effects « of infant day-care reconsidered: Risk for parents, children and researchers, Early Childhood Quaterly 3, (1988), 293-318. ${ }^{46}$ Elies Hennessy, Edvard C. Melhuish, Early day care and the development of school-age children: A review, Journal of Reproductive and Infant Psychology 9 (1991), 17-136.
} 
Zelo pomemben zaključek, ki ga lahko potegnemo iz tega obdobja, je spoznanje, da je predvsem kakovost tista, ki določa in daje organizirani predšolski vzgoji trajne in pozitivne učinke. Rutter ${ }^{47}$ ob analizi učinkov predšolskih programov na otrokov razvoj zaključuje: »Dolgotrajni učinki predšolskih programov v edukativnem smislu niso odvisni toliko od tega, česa se otrok specifično nauči, ampak vplivajo predvsem na otrokova stališča do učenja, na njegovo samozaupanje in vztrajnost pri doseganju ciljev«.

Za drugi val raziskav je značilno, da skušajo naravo organizirane predšolske vzgoje in njenega učinka na otroke opredeliti z različnih perspektiv in da bolj diferencirano in analitično pristopajo $\mathrm{k}$ njenemu raziskovanju. Že konec osemdesetih let so nekateri strokovnjaki napovedovali nov val raziskav na področju organizirane predšolske vzgoje. ${ }^{48} \mathrm{~V}$ tem valu postaja prav ocenjevanje kakovosti znotraj posamezne vrste organizirane predšolske vzgoje posebej zanimivo vprašanje, ${ }^{49} \mathrm{ki}$ ga skušajo osvetliti z vidika širšega konteksta. Velik napredek je bil storjen tudi v prepoznavanju značilnosti oziroma kazalcev okolja v organizirani predšolski vzgoji, ki nudijo skrbno in kakovostno okolje za majhnega otroka. Napredek pa je nastal tudi na nivoju raziskovanja kompleksnosti odnosov med vrtcem in domom oziroma širšim družbenim kontekstom.

V nadaljevanju najprej prikazujemo pregled raziskav, v katerih so dokazovali, kakšen je vpliv višje kakovosti organizirane predšolske vzgoje na otroke in njihov razvoj. V preglednici 3 prikazujemo področje vpliva in študijo oziroma vir, ki je takšen vpliv dokazal.

\begin{tabular}{|l|l|}
\hline \multicolumn{1}{|c|}{ Področje vpliva } & \multicolumn{1}{c|}{ Vir (raziskava) } \\
\hline Višji nivo interakcije z vrstniki & Field, 1980 \\
\hline Boljši socialni razvoj & $\begin{array}{l}\text { McCartney, 1984; Phillips, McCartney, } \\
\text { Scarr, 1987 }\end{array}$ \\
\hline Pozitivnejša čustva & Howes, 1990 \\
\hline Boljše socialne spretnosti & $\begin{array}{l}\text { Cost, Quality and Child Outcomes Study } \\
\text { Team, 1995 }\end{array}$ \\
\hline Višja stopnja zahtevnosti igre z vrstniki & $\begin{array}{l}\text { Dunn, 1993; File, Kontos, 1993; Howes, } \\
\text { Smith, Galinsky, 1995 }\end{array}$ \\
\hline
\end{tabular}

\footnotetext{
${ }^{47}$ Michael Rutter, Family and school influence on behavioural development, Journal of Child Psychology 26, (1985), 349-368, 683-704.

${ }^{48}$ Alison K. Clarke-Stewart, The »effects« of infant day-care reconsidered: Risk for parents, children and researchers, Washington 1988, 293-318.

${ }^{49}$ Harry McGurk, Marlene Caplan, Eilis Hennessy, Peter Moss, Controversy, Theory and Social Context in Contemporary Day Care Research, London 1993, 3-23.
} 


\begin{tabular}{|c|c|}
\hline Področje vpliva & Vir (raziskava) \\
\hline $\begin{array}{l}\text { Višji nivo sposobnosti reševanja socialnih } \\
\text { problemov }\end{array}$ & Holloway, Reichart-Erickson, 1988 \\
\hline Manj resnih vedenjskih problemov & $\begin{array}{l}\text { Howes, Smith, Galinsky, 1995; Love, Ryer, } \\
\text { Faddis, 1992; Kontos, } 1991\end{array}$ \\
\hline $\begin{array}{l}\text { Boljša socialna prilagojenost in manj social- } \\
\text { no deviantnega obnašanja }\end{array}$ & Dunn, 1993; Kontos, 1991 \\
\hline Otroci se manj upirajo odraslim & $\begin{array}{l}\text { Howes, Olenick, 1986; Peterson, Peter- } \\
\text { son, } 1986\end{array}$ \\
\hline $\begin{array}{l}\text { Otroci se v komunikaciji bolje obračajo tako } \\
\text { na odrasle kot na druge otroke }\end{array}$ & Howes, Phillips, Whitebook, 1992 \\
\hline Višji nivo samoregulacije otrok & Howes, Olenick, 1986 \\
\hline $\begin{array}{l}\text { Otroci so bolj usmerjeni na dejavnost, nalo- } \\
\text { go, ki jo opravljajo }\end{array}$ & $\begin{array}{l}\text { McCartney in drugi, 1985; Phillips, McCa- } \\
\text { rtney, Scarr, } 1987\end{array}$ \\
\hline $\begin{array}{l}\text { Višji nivo razvoja na področju razumevan- } \\
\text { ja jezika }\end{array}$ & $\begin{array}{l}\text { Cost, Quality and Child Outcomes Study } \\
\text { Team, 1995; McCartney in drugi, 1985; } \\
\text { Schliecker, White, Jacobs, } 1991\end{array}$ \\
\hline $\begin{array}{l}\text { Otroci so boljši na testih predmatematičnih } \\
\text { sposobnosti (štetje, primerjanje) }\end{array}$ & $\begin{array}{l}\text { Stuber, 1992, Cost, Quality, and Child } \\
\text { Outcomes Study Team, } 1995\end{array}$ \\
\hline $\begin{array}{l}\text { Otroci so boljši na testih verbalne inteli- } \\
\text { gentnosti }\end{array}$ & McCartney, 1984 \\
\hline $\begin{array}{l}\text { Otroci so kasneje v šoli manj moteči, bolj us- } \\
\text { merjeni na naloge in pozorni }\end{array}$ & Howes, 1988 \\
\hline $\begin{array}{l}\text { Otroci so kasneje v šoli bolj veseli, manj } \\
\text { boječi, bolj socialno kompetentni, imajo bolj } \\
\text { prijateljske odnose z vrstniki }\end{array}$ & Vandell, Henderson, Wilson, 1988 \\
\hline $\begin{array}{l}\text { Otroci, ki obiskujejo jasli, so kasneje bolj } \\
\text { družabni, manj socialno izolirani, manj } \\
\text { agresivni }\end{array}$ & Howes, Hamilton, 1993 \\
\hline $\begin{array}{l}\text { Otroci, ki obiskujejo jasli, so kasneje oseb- } \\
\text { nostno bolj zreli, imajo višjo stopnjo social- } \\
\text { nih sposobnosti v interakciji z vrstniki in } \\
\text { odraslimi }\end{array}$ & Lamb in drugi, 1988 \\
\hline $\begin{array}{l}\text { Otroci bolje napredujejo v šoli, bolj sodeluje- } \\
\text { jo pri pouku v prvem razredu }\end{array}$ & Howes, 1988 \\
\hline $\begin{array}{l}\text { Otroci so v šestem razredu pogosteje } \\
\text { razporejeni v razrede za nadarjene in imajo } \\
\text { boljše ocene iz matematike }\end{array}$ & Field, 1991 \\
\hline $\begin{array}{l}\text { Višja ocena staršev in vzgojiteljev o otrokovi } \\
\text { pozornosti, socialni izkušenosti, zmožnosti } \\
\text { usmeriti se na določeno nalogo }\end{array}$ & Phillips, McCartney, Scarr, 1987 \\
\hline
\end{tabular}




\begin{tabular}{|l|l|}
\hline \multicolumn{1}{|c|}{ Področje vpliva } & \multicolumn{1}{|c|}{ Vir (raziskava) } \\
\hline $\begin{array}{l}\text { Imajo višje ocene na testu socialne kompe- } \\
\text { tentnosti }\end{array}$ & Kontos, Fiene, 1987 \\
\hline $\begin{array}{l}\text { Imajo več pozitivnega obnašanja z vrstniki } \\
\text { in odraslimi }\end{array}$ & Vandell, Powers, 1983 \\
\hline $\begin{array}{l}\text { Pospešen je kognitivni razvoj otrok, še pose- } \\
\text { bej tistih iz nižjih socialno-kulturnih slojev }\end{array}$ & Hennessy, Melhuish, 1991 \\
\hline $\begin{array}{l}\text { Pozitivni kratkoročni in dolgoročni učinki } \\
\text { na otrocih }\end{array}$ & $\begin{array}{l}\text { Andersson, 1992; Field, 1991; Schweinhart, } \\
\text { Weikart, 1985, 1993; Sylva, 1990, 1992; Syl- } \\
\text { va, Wiltshire, 1993; Pascal, 1990 }\end{array}$ \\
\hline
\end{tabular}

Preglednica 3: V raziskavah dokazani vplivi višje kakovosti organizirane predšolske vzgoje na razvoj otrok.

Večina teh raziskav je nastala $\mathrm{v}$ zadnjem desetletju prejšnjega stoletja in $\mathrm{v}$ vseh so empirično dokazali pozitivne vplive višje kakovosti organizirane predšolske vzgoje na otrokov razvoj. Vse prikazane raziskave so v bistvu ugotavljale učinke visoko kvalitetnih predšolskih programov v primerjavi z manj kvalitetnimi programi. Večina teh raziskav je zaključke gradila na kratkoročnih učinkih, nekatere pa tudi na dolgoročnih učinkih na otrocih.

Iz preglednice je razvidno, da višja kakovost organizirane predšolske vzgoje vpliva na različna področja otrokovega razvoja kot so socialni razvoj, čustveni, kognitivni in jezikovni razvoj, vplivi pa so tako kratkoročni kot tudi dolgoročni. Raziskave so torej v tem obdobju že usmerjale pozornost na učinke iz različnih področij otrokovega razvoja in postopno opuščale usmerjenost le na ožje kognitivne učinke. Takšen razvoj že lahko pripišemo spoznanju, da so se gledanja na celostnost otrokovega razvoja spremenila tudi zaradi novih ciljev, ki sta jih vzgoja in izobraževanje razvila kot odgovor na spremembe v družbi.

Tudi v evropskem prostoru so raziskave o učinkih institucionalne predšolske vzgoje pokazale, da se začetna prednost otrok, ki so bili vključeni v organizirano predšolsko vzgojo, porazgubi v nadaljevanju šolanja. ${ }^{50}$ Raziskave pa so bile usmerjene tudi na primerjanje učinkov različnih programov. Tako sta Jowett in Sylva ${ }^{51}$ primerjali otroke, ki so obiskovali t. i. » nursery program « in program igralnih skupin. Za program igralnih skupin velja, da temelji na prosti igri, medtem ko so odrasli zadolženi predvsem za

${ }^{50}$ George Smith, Terry James, The effect of preschool education, London 1977.

${ }^{51}$ Sandra Jowett, Kathy Sylva, Does kind of preschool matter? Educational research, Oxford 1986, $21-31$. 
pripovedovanje pravljic in nudenje pogojev za igro. Vpliv odraslih na otrokovo igro $\mathrm{v} \gg$ nursery programu « pa je večji, prav tako je $\mathrm{v}$ tem programu več igre $v$ večjih skupinah. Rezultati so pokazali, da so bili otroci iz $\gg$ nursery programa« uspešnejši v namenski in kompleksni igri. Med dejavnostmi, ki so jih izbirali sami, so zbirali in izpolnjevali delovne lističe, brali in listali knjige, pogosteje so iskali in vzpostavljali kontakt z vzgojiteljico, bili bolj vedoželjni, izkazali so večjo vztrajnost in neodvisnost v situacijah, ko so naleteli na ovire. Otroci iz programa igralnih skupin pa so več časa zapravili za klepetanje ali ogledovanje slik v knjigah in pri učitelju iskali le pomoč. Rezultati študije so pomembni, saj kažejo, da vrsta predšolskih izkušenj vpliva na to, kako lahko otrok začenja svojo šolsko kariero.

Clarke-Stewartova je v letu $1988^{52}$ analizirala vse pomembne britanske raziskave o učinkih predšolskih programov. Njena študija povzema naslednje:

- večina študij kaže, da je vključevanje otrok v predšolske programe povezana s pozitivnimi koristmi za otroka;

- britanske raziskave ne kažejo koristnih učinkov jasličnih programov;

- opravljenih je bilo premalo študij, ki bi pokazale, katere vrste predšolskih programov prinašajo najbolj uspešne učinke.

V longitudinalni študiji Osborna in Millbanka ${ }^{53}$ pa je bila na približno 8.400 otrocih, rojenih leta 1970 , dokazana tesna zveza med vključenostjo v predšolski program in uspehom pri branju in matematiki ter socialnim vedenjem otrok pri desetih letih. Rezultati so pokazali, da so imeli otroci, ki so bili vključeni $\mathrm{v}$ edukativno orientirane vrtce, pred vstopom $\mathrm{v}$ šolo bolje razvite kognitivne in socialne funkcije kot tisti, ki so bili do vstopa $v$ šolo doma ali pa vključeni v predšolske programe, ki so bili usmerjeni predvsem na nego otrok.

Veliko raziskovalnih študij je bilo usmerjenih tudi na proučevanje vplivov dnevnega varstva na otrokovo emocionalno prilagajanje, posebej še na odnos do matere. ${ }^{54}$ Še vedno namreč med strokovnjaki obstaja razkol glede pogledov na to, ali je zgodnji vstop otrok (npr. pred enim letom) v dnevno varstvo škodljiv za otrokov kasnejši razvoj ali ne. V študiji na Švedskem ${ }^{55}$ so spremlja-

\footnotetext{
${ }^{52}$ Alison K. Clarke-Stewart, The »effects « of infant day-care reconsidered: Risk for parents, children and researchers, Washington 1988, 293-318.

${ }^{53}$ Albert F. Osborn, Janet E. Milbank, The effects of early education: A report from the Child Health and Education Study, Oxford 1987.

${ }^{54}$ A. K. Clarke-Stewart, n. d.

${ }_{55}$ Bengt-Erik Andersson, Effects of public day care: a longitudinal study, Child Development (1989), 857-866; Moncrieff Cochran, Lars Gunnarsson, A follow-up study of group day-care and family based rearing patterns, Journal of Marriage and the Family 47 (1985), 297-309.
} 
li otroke do vstopa v srednjo šolo in niso našli dokazov, da bi dnevno varstvo dojenčkov in malčkov škodovalo njihovemu emocionalnemu razvoju.

Po drugi strani pa študije v Ameriki opozarjajo, da zgodnje vključevanje otrok v dnevno varstvo povzroči anksiozno navezanost otrok na mater, emocionalno odvisnost, slabe odnose $\mathrm{z}$ vrstniki in agresijo. ${ }^{56}$ Primerjava rezultatov teh študij kaže, kako pomembno je pri interpretaciji kakovosti upoštevati celoten družbeni kontekst, v katerem se učinki merijo. Raziskavi sta namreč pokazali nasprotujoče si rezultate longitudinalnih študij, ki so jih izvajali na Švedskem ${ }^{57}$ in v Teksasu ${ }^{58}$ o dolgoročnih učinkih zgodnjega vključevanja otrok v institucije. Medtem ko ameriška študija kaže, da imajo otroci, ki so bili vključeni v institucijo kot dojenčki, slabše odnose z vrstniki, slabše delovne navade, se težje disciplinirajo in so emocionalno manj stabilni, imajo slabše rezultate $\mathrm{v}$ šolskih znanjih in slabše rezultate na standardiziranih testih, pa švedska študija kaže nasprotno. Anderssonove študije kažejo, da otroci, ki so bili zgodaj vključeni v visoko kvalitetne institucije na Švedskem, bolje uspevajo v šoli in prejemajo bolj pozitivne ocene svojih učiteljev glede socialnih in emocionalnih sposobnosti kot njihovi vrstniki, ki niso imeli te izkušnje. Poleg kakovosti institucij (število otrok v skupini, interakcija med otroki in vzgojnim osebjem, usposobljenost osebja, trajanje programa ipd.) je na rezultate zanesljivo vplivala še vrsta drugih faktorjev, ki se med obema okoljema razlikujejo in odsevajo integriranost te dejavnosti v nacionalne programe skrbi za družino in otroke ter kulturo, kot so npr. položaj otrok v družbi, kulturna tradicija v skrbi za otroke in njihove pravice ipd.

Posebno pozornost so raziskovalci namenili tudi proučevanju učinkov vključevanja otrok v institucionalno predšolsko vzgojo po prvem letu starosti. Osborn in Millbank ${ }^{59}$ sta primerjali edukativne in socialne učinke na otrocih, ki so obiskovali celodnevno varstvo, s tistimi, ki so hodili v poldnevno varstvo ali pa sploh niso bili vključeni v institucionalno predšolsko vzgojo. Ugotavljata, da imajo otroci iz celodnevnega varstva nižje vrednosti na matematičnem testu in višjo stopnjo vedenjskih problemov v osnovni šoli. McGuire in Richman ${ }^{60}$ sta prav tako ugotovila, da imajo otroci, ki

\footnotetext{
${ }^{56}$ Deborah Lowe Vandell, Mary Anne Corasaniti, Variations in Early Child Care: Do They Predict Subsequent Social, Emotional and Cognitive Differences?, Early Childhood Research Quarterly 5 (1990), 55-72.

${ }^{57}$ B.-E Andersson, n. d., 857- 866; Effects of day care on cognitive and socio-emotional competence in thirteen years old Swedish schoolchildren, Child Development 63 (1992), 20-36.

${ }^{58}$ D. L. Vandell, M. A Corasaniti, n. d.

${ }^{59}$ A. F. Osborn, J. E. Milbank, n. d.

${ }^{60}$ Jacqueline Mcguire, Naomi Richman, The prevalence of behaviour problems in three types of preschool group, Journal of Child Psychology and Psychiatry 27 (1986), 455-472.
} 
obiskujejo centre za dnevno varstvo, več emocionalnih in vedenjskih problemov, kot pa otroci, ki obiskujejo igralne skupine. Razlog za ta pojav pripisujeta dejstvu, da so v centre za dnevno varstvo vključeni predvsem otroci iz socialno ogroženih družin, ki imajo številne probleme.

Raziskave iz Švedske ${ }^{61}$ pa nasprotno kažejo, da nudijo izkušnje iz dnevnega varstva otrokom boljše možnosti za start v šoli. Andersson je opazoval otroke iz nižjega in srednjega sloja v Götheburgu od otrokovega prvega dne $\mathrm{v}$ vrtcu pa do trinajstega leta in to na vzorcu, ki je dovolj dobro predstavljal normalne družine $\mathrm{z}$ majhnimi otroki v velikih mestih. Otroke, ki so bili v dnevnem varstvu, je primerjal z otroki, ki so ostali doma, in sicer tako, da je meritve ponovil pri osmem letu in pri trinajstih letih. V prvi longitudinalni študiji ${ }^{62}$ je ugotavljal, ali so različni tipi varstva otrok ter vstopa otroka v izvendružinsko varstvo možni dejavniki otrokovega razvoja. Rezultati so pokazali, da so imeli otroci, ki so zgodaj (v drugi polovici prvega življenjskega leta) vstopili v dnevno varstvo, pomembno višje rezultate na kognitivnih testih. Hkrati so dobili bolj pozitivne ocene svojih učiteljev na lestvici šolske uspešnosti in socialno osebnostnih lastnosti, kot pa njihovi vrstniki, ki so vstopili v dnevno varstvo kasneje ali pa so bili ves čas pred vstopom $v$ šolo doma in torej niso imeli izkušenj z varstvom zunaj doma. Pozitivni rezultati, ki so vezani na zgodnji vstop v dnevno varstvo, so v nasprotju s tem, kar naj bi pričakovali po analizi ameriških raziskav, ${ }^{63}$ ki kažejo, da so otroci, ki vstopijo v dnevno varstvo pred prvim letom starosti in tam ostanejo za najmanj 25 ur tedensko, bolj ogroženi, ker razvijejo bolj negotove vzorce navezanosti na svoje matere. Andersson pri tem in na osnovi svojih ugotovitev podaja dve hipotezi in sicer:

- dnevno varstvo, ki se začne po šesem mesecu je bolj blagodejno za otroke kot tisto, ki se začne prej, ker na ta način to dnevno varstvo ni nadomestek za sicer v družbi plačano odsotnost staršev v času prvega leta otrokove starosti. Pri tem se starševska odgovornost krepi;

- pojavijo se negativni efekti, če je program slabe kakovosti.

Andersson je v tej študiji na vzorcu na Švedskem ugotovil, da sta starost vstopa $\mathrm{v}$ javno zunajdružinsko varstvo ter tip tega varstva pomembna spremenljivka v predvidevanju otrokovega kognitivnega, socialnega in čustvenega razvoja. Pri osmem letu so imeli otroci, ki so vstopili v dnevno varstvo

${ }^{61}$ B.-E Andersson, n. d. $(1989,1992)$.

${ }^{62}$ B.-E Andersson, n. d. (1989).

${ }^{63}$ Jay Belsky, Two waves of day care research: Developmental effects and condition of quality, v: Ainskie (ur.), The child and day care setting, New York 1984; A. K. Clarke-Stewart, Infant day care maligned or malignant? American Psychologist 44/2 (1989), 266-273. 
pri šestih mesecih, torej v drugi polovici prvega življenjskega leta, boljši šolski uspeh ter višje dosežke na testih sposobnosti kot tisti, ki so vstopali kasneje ali pa sploh niso bili vključeni v zunajdružinsko varstvo. Ti otroci so bili ocenjeni kot bolj vztrajni in neodvisni, bolj verbalno sposobni, manj anksiozni, bolj socialno samozavestni - prehod iz vrtca v šolo je bil pri njih manj problematičen. Na nobeni od merjenih postavk niso zasledili negativnih učinkov zgodnjega dnevnega varstva. Ti rezultati so pravzaprav v nasprotju z rezultati, ki jih je prikazal Belsky, ${ }^{64}$ čeprav nekateri avtorji poudarjajo, da doslej ni podatkov, ki bi dokazali zanesljivo slab vpliv teh institucij na otrokov razvoj, kot meni Belsky. ${ }^{65}$

V študiji iz leta 1992 pa Andersson ${ }^{66}$ ugotavlja vpliv zgodnjega vključevanja otroka v organizirano predšolsko vzgojo na njegov kognitivni razvoj, socialne in čustvene sposobnosti pri osmem in trinajstem letu starosti v odvisnosti od različnih družinskih variabel, otrokovih lastnosti in predšolskih izkušenj. Na ta način naj bi ugotovil, ali so učinki zgodnje institucionalne vzgoje trajnega ali prehodnega značaja. Kar zadeva moč napovedi, ta študija kaže dolgotrajne učinke zgodnje institucionalne predšolske vzgoje. Pri osmem in trinajstem letu starosti je šolska uspešnost nižja pri tistih, ki niso imeli zunajdružinskih izkušenj z organizirano predšolsko vzgojo. Podobni rezultati so pri nekaterih socialnih in emocionalnih spremenljivkah. Šolska uspešnost je višja pri tistih, ki so začeli institucionalno predšolsko vzgojo pred prvim letom starosti od tistih, ki te izkušnje izven doma niso imeli. Isto velja za socialno kompetentnost pri trinajstem letu. V nobenem primeru pa niso ugotovili negativnih učinkov zgodnjega vključevanja v dnevno varstvo pri osmih ali trinajstih letih. Tip družine je vplival na čas, v katerem se otrok vključi v dnevno varstvo. Socialno-ekonomski status družine in otrokova inteligentnost vplivata na socio-emocionalno kompetenco pri osmem in trinajstem letu starosti.

Koncem osemdesetih in $\mathrm{v}$ začetku devetdesetih let so dozorela spoznanja o pomenu upoštevanja kulturnega in ekološkega konteksta pri obravnavi kakovosti organizirane predšolske vzgoje. To je prineslo bistvene elemente za interpretacijo rezultatov, ko je Andersson ${ }^{67}$ dokazal hipotezo, da

\footnotetext{
${ }^{64} \mathrm{~J}$. Belsky, The »effects « of infant day care reconsidered, Early Childhood Research Quarterly 3 (1988), 235-272.

${ }^{65}$ Alison K. Clarke-Stewart , The »effects « of infant day-care reconsidered: Risk for parents, children and researchers, Early Childhood 2uaterly 3 (1988), 293-318; Deborah Phillips, Kathleen McCartney, Sandra Scarr, Child care quality and children's social development, Developmental Psychology 23 (1987), 537-543.

${ }^{66}$ B.-E Andersson, n. d. (1989).

${ }^{67}$ B.-E Andersson, n. d. $(1989,1992)$.
} 
če majhnim otrokom nudimo pozitivne izkušnje, toplino, visoko kvalitetno nego, lahko s tem pospešimo njihov razvoj tudi za v bodoče. Če pa se jim nudi nizka kakovost teh uslug, lahko to pripelje do negativnih učinkov, ki so lahko tudi trajnejšega značaja, kot sta npr. ugotovila Vandell in Corasaniti v Teksasu. ${ }^{68}$ Javno dnevno varstvo v ZDA je pogosto nizke kakovosti, medtem ko se privatno dnevno varstvo, ki ga financirajo družine ali neprofitne nevladne organizacije, nagiba $k$ večji kakovosti in ju uporabljajo starši iz srednjega sloja in tudi tisti z nizkimi prejemki.

Howesova $^{69}$ je v svoji študiji spremljala 80 otrok: polovica je bila v izjemno kvalitetnih vrtcih, druga polovica pa v centrih dnevnega varstva $\mathrm{z}$ nizko kvalitetnimi programi. Za visoko kvalitetne centre je bilo značilno:

- stabilno organizirana vzgoja in nega otrok, tako da je otrok v interakciji le z nekaj vzgojitelji v enem dnevu;

- stalnost vzgojiteljev, tako da se otrok srečuje z istimi vzgojitelji skozi daljše časovno obdobje;

- dobro usposobljeno vzgojno osebje, ki je osveščeno o otrokovem razvoju;

- nizko razmerje med otroki in odraslimi v oddelku (v prvem letu 1:3, v obdobju od 1.-3. leta 1:4, od 4.-6. leta 1:8-12).

Pri vseh otrocih so kontrolirali družinsko ozadje in individualne razlike. Rezultati kažejo, da so bili otroci, ki so bili vključeni v visoko kvalitetne centre, boljši na edukativnih in socialnih meritvah. Otroci, ki so bili vključeni v centre z nizko kvalitetnimi programi, pa teh uspehov niso dosegali, še zlasti velja to za otroke, ki so bili v te centre vključeni pred prvim letom starosti. Posebej slabo so se ti otroci odrezali pri opravljanju nalog, koncentraciji in pri sodelovanju z vrstniki.

Če povzamemo rezultate raziskav na Švedskem in v ZDA, lahko ugotovimo, da prisotnost otrok v organizirani predšolski vzgoji, ki je visoko kvalitetna, ne škoduje otrokovim možnostim v kasnejšem življenju. Švedske študije celo opozarjajo, da jim to daje boljše startne možnosti za življenje. Pri tem nekateri avtorji ${ }^{70}$ opozarjajo, da ne moremo razumeti vplivov organizirane predšolske vzgoje na otrokov razvoj, če pri tem ne upoštevamo socialnega in kulturnega konteksta. Zato je za vse sodobne študije ${ }^{71}$ značil-

\footnotetext{
${ }^{68}$ D. L. Vandell, M. A Corasaniti, n. d.

${ }^{69}$ Carollee Howes, Can the Age of Entry into Child Care and the Quality of Child Care Predict Adjustment in Kindergarten?, Developmental Psychology 26 (1990), 292-303.

${ }^{70}$ Harry McGurk, Marlene Caplan, Eilis Hennessy, Peter Moss, Controversy, Theory and Social Context in Contemporary Day Care Research, Child Psychology Psychiatry 34/1 (1993), 3-23.

${ }^{71}$ Edvard C. Melhuish, Eva Lloyd, Susan Martin, Ann Mooney, Type of Child Care at 18 Months - II. Relations with Cognitive and Language Development, Journal of Child Psycholo-
} 
no, da so demografski vzorci strogo opisani, kar dokazuje visoko stopnjo osveščenosti o pomenu upoštevanja socialnega, kulturnega in širšega družbenega konteksta pri analiziranju vplivov organizirane predšolske vzgoje.

Raziskave tudi v tem primeru jasno dokazujejo, da ima kvalitetno organizirana predšolska vzgoja na otrokov razvoj pozitivne učinke, ki so trenutne in dolgoročne narave. Ti in podobni rezultati raziskav so mednarodno strokovno javnost vse bolj prepričevali, kako pomembno je zagotavljanje ustreznih kvalitetnih pogojev za življenje majhnih otrok in njihov celostni razvoj. S tem v zvezi pa je še kako pomembno zagotavljati kvalitetno organizirano predšolsko vzgojo za kasnejši razvoj posameznika in razvoj družbe kot celote.

\section{Kakovost organizirane predšolske vzgoje $z$ vidika staršev}

Organizirana predšolska vzgoja se uresničuje v strokovnih institucijah, ki nudijo otrokom in njihovim družinam celostne usluge za dopolnjevanje nege in vzgoje, ki jo otroci dobijo v svojih družinah. Organizirana predšolska vzgoja ni in ne more biti nadomestilo za družinsko nego in vzgojo ali biti tekmec staršem pri vzgoji in negi njihovih otrok. Do neke mere pa vrtec lahko predstavlja razširjeno družino, takšno, ki je združljiva in prilagojena socialni realnosti modernega sveta.

Potreba po razširjenosti in množičnosti organiziranih programov je odvisna od demografskih značilnosti družin v vsakem konkretnem okolju. Družine z zaposlenimi starši, družine z enim roditeljem ali družine, kjer

gy and Psychiatry 31/6 (1990), 861-870; C. Howes, n. d. (1990); Tiffany Field, Quality infant day-care and grade school behaviour and performance, Child Development 62 (1991), 863-870; Evelyn Schliecker, Donna R. White, Ellen Jacob, The Role of Day Care Quality in the Prediction of Children's Vocabulary, Canadian Journal of Behavioral Science 23/1 (1991), 12-24; Susan J. Kontos, Child Care Quality, Family Background, and Children's Development, Washington D. C. 1991, 249-262; Margaret Stuber, Quality of Center Care and Preschool Cognitive Outcomes: Differences of Family Income, v: P. A. Adler, P. Adler (ur.), Sociological Studies of Child Development, vol. 5., Greenwich 1992; John M. Love, Paul Ryer, Bonnie Faddis, Caring Environments - Program Quality in California's Public Funded Child Development Programs: Report on the Legasletively Mandaten 1990-91 Staff/Child Ratio Study, Portsmouth 1992; C. Howes, Claire E. Hamilton, Child Care for Young Children - Handbook of research on the education of young children, New York 1993; C. Howes, D. Philipps, Marcy Whitebook, Thresholds of quality implications for the social development of children in center based child care, Child Development 62 (1992), 449-460; Linda L. Hestenes, Susan Kontos, Yvonne Bryan, Children's Emotional Expression in Child Care Centers Varying in Quality, Early Childhood Research 2uarterly 8 (1993), 295-307; Loraine Dunn, Proximal and Distal Features of Day Care Quality and Children, Early Childhood Research Quarterly 8 (1993), 167-192; C. Howes, Ellen Smith, Ellen Galinsky, The Florida Child Care Quality Improvement Study: Interim report, New York 1995; Cost, quality and child outcomes study team, Cost, Quality and Child Outcomes in Child Care Centers: Public Report, Denver 1995. 
ima eden od staršev kakršnokoli motnjo, ki zmanjšuje njihovo zmožnost za otrokovo nego in skrb, jih seveda bolj potrebujejo. Druge družine potrebujejo predšolske programe, v katere vključujejo otroka občasno ali za krajši čas, malo družin pa je takšnih, ki jih ne bi potrebovale nikoli.

$\mathrm{Ne}$ glede na to, kako pogosto želi družina sodelovati z institucijami za predšolsko vzgojo, skorajda ni družine, ki za svojega otroka ne bi želela »dobrega vrtca«. Seveda so pričakovanja družin v odnosu do »dobrega vrtca sila različna in v večini primerov laična. Starši namreč največkrat nimajo dovolj informacij o tem, kaj tvori kakovost vrtca ali predšolskega programa in kje jo lahko najdejo. Poleg tega pa starši gledajo na vrtec ali program z vidika svojih potreb. Kljub temu z zanesljivostjo lahko trdimo, da starši želijo kvalitetne usluge vrtca ali drugih izvajalcev organizirane predšolske vzgoje za svoje otroke. Njihovo kakovost gledajo z vidika svojega otroka. Vrtec ali program bo za njih kakovosten, če se bodo njihove predstave, želje in potrebe o tem, kaj njihov otrok in oni potrebujejo, čimbolj ujemale $s$ tem, kar se v vrtcu ali v programu v resnici ponuja oziroma izvaja. Starši seveda želijo tudi uslugo, ki ne bo moteča za njihovo življenje in ki bo čim bližje njihovim potrebam, možnostim in željam tako prostorsko, časovno kot tudi po vsebini in ceni. Na kakovost večina staršev gleda precej laično in z vidika svojih lastnih potreb in želja.

Omenili smo že, da organizirana predšolska vzgoja ni homogen prostor. V tem okviru se pojavljajo različni programi, ki jih izvajajo različni izvajalci, čeprav so to v najbolj pogostih primerih specialne, strokovne predšolske institucije, ki jih v svetu poznajo pod različnimi nazivi, pri nas pa jo imenujemo vrtec. Vendar se tudi znotraj dejavnosti, ki jo opravlja vrtec, pojavljajo različni programi, kot so npr. celodnevno varstvo, poldnevni programi, igralne urice ipd. In končno je potrebno poudariti, da se vrtci med seboj razlikujejo tako po programih, ki jih ponujajo, kot tudi po doseženi kakovosti teh programov. Že samo dejstvo, v kolikšni meri je vrtec sposoben odzivanja na potrebe otrok in njihovih staršev, odraža kakovost vrtca. Raznolikost programov, ki jih vrtec ponuja, zadovoljuje pravico in potrebe staršev do izbire.

Znotraj vrtca lahko obstajajo tudi razlike v kakovosti istega programa. Kakovost je torej lahko različna tako med različnimi programi in različnimi vrtci kot tudi med istimi programi v istem vrtcu, torej znotraj enega vrtca, v odvisnosti od konceptualnih izhodišč programa, osebnostnih značilnosti in usposobljenosti osebja, ki je v vrtcu, fizičnih pogojev in objektivnih pogojev, v katerih se program izvaja, in podpore, ki jo dobi iz okolja in od družbe v celoti. 
Dokazano pa je, da kvalitetni vrtci lahko pomagajo staršem učiti, motivirati in zagovarjati svojega otroka. Trdimo lahko, da se z odpiranjem vrtca do staršev in njihovih potreb kakovost organizirane predšolske vzgoje zvišuje. In končno starši to tudi želijo. Nekatere raziskave potrjujejo, da starši dajejo največji pomen pri ocenjevanju vrtca interakciji (z vzgojiteljem/ vzgojiteljico), zdravju in varnosti. ${ }^{72}$

V kvalitetnem vrtcu pride do občutka medsebojne odgovornosti in partnerskega odnosa med starši in vzgojnim osebjem pri vzgoji in negi otrok. Uspeh intervencijskih programov sloni prav na tej značilnosti, ${ }^{73}$ saj se preko staršev lahko zgradi uspešno povezanost s skupnostjo. Tudi trenutno eden najpopularnejših predšolskih programov Reggio Emilia je po mnenju strokovnjakov tako uspešen, ${ }^{74}$ ker ima svoje osnove v kulturni kontinuiteti in vključevanju skupnosti, ki daje programu (in s tem otrokom in staršem) smiselnost njihovih izkušenj oziroma dejavnosti v vrtcu. Zato program, takšen kot je bil v svojih najboljših časih, ni bil uspešno prenosljiv v druga okolja. Po mnenju nekaterih strokovnjakov je program že začel doživljati krizo prav zato, ker je na široko odprl vrata otrokom iz drugih kulturnih okolij in zgubil status kulturne primernosti za vse otroke.

\section{Kakovost organizirane predšolske vzgoje $\mathrm{z}$ vidika širše skupnosti}

Ideja o tem, da je organizirana predšolska vzgoja povezana s širšimi družbenimi potrebami in interesi, ni nova. Tako so obravnavali vprašanja organizirane predšolske vzgoje $\mathrm{v}$ tesni povezanosti z vprašanji žensk in z zaposlovanjem v družbi. Po eni strani vrtec omogoča zaposlovanje staršev, po drugi strani pa lahko kvalitetni vrtci vplivajo tudi na učinkovitost in uspešnost staršev, predvsem mater na delovnem mestu. ${ }^{75} \mathrm{~S}$ to idejo pa smo se srečali že ob prvih poskusih organizirane predšolske vzgoje, ki jih je izpeljal Robert Owen v začetku 19. stoletja, ko je za otroke svojih delavcev organiziral vrtec.

\footnotetext{
${ }^{72}$ Debby Cryer, Margaret Burchinal, Parents as child care consumers, Early Childhood Quarterly 12 (1997), 35-58.

${ }^{73}$ Louisa B. Tarullo, Effective Early Childhood Programs: The U.S. head Start Experience, v: M. E. Eming Young (ur.): From Early Child Development to Human Development, Investing in our child future, Washington D. C. 2002; Simone Kirpal, Communities can make a Difference: Five Cases across Continents, v: E. Eming Young (ur.), n. d.

${ }^{74}$ Lillian G. Katz, Impressions of Reggio Emilia Preschools, Young Children 45/6 (1990), 1112; Rebecca New, Excellent early education: A city in Italy has it, Young Children 45/6 (1990), 4-10.

${ }^{75}$ Barbara Wolfe, Child Care Quality: Does It Matter and Dopes It Need to be Improved? Full Report, New York 2001.
} 
Raziskave kažejo, da starši pogosteje izostajajo iz službe, če so njihovi otroci vključeni v neformalne oblike predšolske vzgoje. Starši otrok, ki so vključeni v formalne oblike (kot npr. privatni, državni, cerkveni vrtci), čutijo njihovo organiziranost kot stabilnost in kakovost, zato jim bolj zaupajo in so na delovnem mestu manj obremenjeni z mislimi na otroka in tako so tudi bolj učinkoviti. ${ }^{76}$ Seveda pa je zaposlovanje le en vidik širšega družbenega interesa, ki je povezan $\mathrm{z}$ vrtcem.

V zadnjih desetih letih je bila predšolska vzgoja deležna več pozornosti s strani družbe in vlad kot kdajkoli doslej v svoji zgodovini. Ta premik se ni zgodil le v razvitih državah, ampak tudi v tistih državah, kjer ta dejavnost ni bila razvita, kot so npr. Brazilija, Filipini, Namibija, Gana. Tako so nastajali nacionalni načrti za pospeševanje družbeno organizirane predšolske vzgoje. $V$ ta prizadevanja so se vključile tudi mednarodne organizacije in fundacije (npr. UNICEF, Svetovna Banka za razvoj, Azijska banka za razvoj, OECD, Save the Children, Matra, USAID) pa tudi privatne fundacije in neprofitne, nevladne organizacije, ki so s svojo dejavnostjo prispevale k spremembam v družbi (Van Leer Foundation, Mott Foundation, Soros Foundation).

K temu preobratu je prispevala predvsem zaveza po uresničevanju Konvencije o otrokovih pravicah ter dejstvo, da so vlade in širša skupnost na organizirano predšolsko obdobje postopno začele gledati kot na obdobje, ki lahko močno prispeva k ekonomskemu in nacionalnemu razvoju. Rezultati raziskav so opozarjali na dolgoročne posledice zanemarjanja otrok, ki povzročajo vseživljenjsko prikrajšanost ter primanjkljaje za družine in širšo skupnost. Ti rezultati so hkrati opozarjali tudi na to, da obstajajo dolgoročne koristi od vlaganj v organizirano predšolsko vzgojo. Organizirana predšolska vzgoja je na ta način začela odgovarjati širšim družbenim potrebam in željam. Po mnenju Doryana, Gautama in Foega ${ }^{77}$ je na ta vprašanja potrebno gledati s širše globalne perspektive, zato navajajo štiri področja, ki so tesno povezana s prizadevanji na področju organizirane predšolske vzgoje in jih v nadaljevanju na kratko opisujemo.

\footnotetext{
${ }^{76}$ Sandra L. Hofferth, Child Care, Maternal Employment and Public Policy, v: Annals of the American Academy 563, North Carolina 1999.

${ }^{77}$ Eduardo A. Doryan, Kul C. Gautam, William H. Foege, The Political change: Commitment and Cooperation, v: E. Eming Young (ur.), n. d.
} 


\section{1. ČL OVEŠKi POTENCIALI}

$S$ programi, ki so namenjeni predšolskim otrokom, pomagamo uresničiti človeške potenciale. Že prednatalno obdobje, v katerem skrbimo za materino zdravje in prehrano, lahko vpliva na vseživljenjske potenciale vsakega posameznika. Na te potenciale pa sedaj že dokazano vpliva tudi psihosocialna stimulacija otrok v predšolskem obdobju.

\section{2. ČLovekove PRAVICE}

Bistvo človekovih pravic je zaščita šibkih in ranljivih pred tiranijo močnih in tistih, ki imajo oblast. V Deklaraciji o človekovih pravicah in Konvenciji o otrokovih pravicah je večina človeštva prepoznala temeljne pravice, dolžnosti in vrednote, ki jih bo spoštovala. Med njimi so pravica do življenja, preživetja, zdravja, prehrane, edukacije in zaščite. Družba, ki spoštuje te pravice, naj bi začela pri njihovem uresničevanju že pri najmlajših članih svoje skupnosti. Zaščita pravic otrok, ki sami tega ne zmorejo, niti ne zmorejo zagotoviti svojega preživetja, rasti in razvoja, je obveza vseh odraslih in vseh držav, ki so ta dokument podpisale. Zanemarjanje uresničevanja otrokovih pravic pomeni nespoštovanje obvez $\mathrm{v}$ odnosu do podpisanih deklaracij. Čeprav se te pravice kršijo tudi med podpisnicami Konvencije, pa sta osveščenost in odgovornost v odnosu do teh problemov vse bolj prisotni na mednarodnem nivoju.

\section{PARTICIPACIJA}

Otroci so tisti del populacije v vsaki državi, ki nimajo svojega glasu v družbi, zato nekateri tudi ne vidijo njihove vloge v zagotavljanju demokracije. Toda način, kako se jih vzgaja in izobražuje, kakšno je njihovo fizično in psihosocialno okolje, kjer rastejo, ima vseživljenjske učinke pri razvoju njihovih vrednot in osebnosti. Če otrok odrašča v atmosferi medsebojnega spoštovanja v najzgodnejših letih svojega razvoja z vrednotami, kot so biti sposoben deliti, prevzemati odgovornost, biti kritičen, zavzemati se za dobrobit socialnega in naravnega okolja ipd., potem vse to lahko prispeva $\mathrm{k}$ oblikovanju demokratičnih vrednot.

$S$ perspektive odraslega demokracija zahteva, da politični predstavniki smotrno uporabljajo javne vire in spoštujejo pravice vseh, ki so jih izvolili. Avtorji pri tem zavzemajo stališče, da je investiranje v predšolsko vzgojo ena najbolj vizionarskih naložb javnega delovanja in politike, ki bi jo morali zagovarjati. 


\section{ZMANJŠEVANJE REVŠČCINE}

Revščina ima mnogo obrazov; med njimi so lakota, bolezni, pomanjkanje možnosti za igro in učenje, nasilje nad otroki in ženami, različne oblike odvisnosti ipd. Pri tem je ena od značilnosti revščine tudi ta, da se ponavlja $\mathrm{v}$ istem krogu in da je prestop iz tega kroga sila težak.

Po mnenju strokovnjakov pomenijo vlaganja $\mathrm{v}$ predšolsko vzgojo najkrajšo pot do tega, da se ponavljajoči cikel revščine preseže. $\mathrm{V}$ ta namen pa bi veljalo okrepiti nacionalno in mednarodno politiko, ki bi podpirala ta prizadevanja. Hkrati s tem pa bo potrebno krepiti vlogo žensk v družbi, saj raziskave kažejo, da otroci bolje živijo in se z njimi bolje ravna v okoljih, kjer imajo ženske dostojanstvo, dostop do virov in politično vplivnost. ${ }^{78}$

Druga dva avtorja ${ }^{79}$ pa navajata etičnost kot najbolj pomemben razlog za investicije $\mathrm{v}$ razvijanje kvalitetnih programov za predšolske otroke, saj po njunem mnenju obstajata dva dramatična problema svetovne skupnosti, in sicer naraščajoče število otrok, ki živi v revščini brez potrebne nege in skrbi, ki jo potrebujejo za razvijanje svojih potencialov, ter reprodukcija revščine.

Tako navajata, da samo v Latinski Ameriki več kot štirje od desetih otrok v starosti pod devet let preživijo na dan z manj kot dvema evroma. Pri tem je število otrok, ki živi v revščini, od leta 1980 naraslo skoraj za dve tretjini. ${ }^{80}$ Otrokom revščine seveda tudi nova doba informacijske tehnologije ne bo pomagala iz revščine, ampak jih bo potisnila le še navzdol, saj si ne bodo mogli razviti potrebnih znanj in veščin za sodelovanje v modernem življenju. Revščina povzroča socialne in druge probleme v skupnosti (nasilje, kriminal, mentalne in druge bolezni ipd.). Glede na vse, kar danes vemo o predšolski vzgoji, si vsak otrok na zemeljski obli zasluži neko korist od tega znanja.

Van der Gaag ${ }^{81}$ pa opozarja na neposredno povezavo med organizirano predšolsko vzgojo in razvojem človeštva. Poudarja štiri pomembne sestavine v razvoju človeštva, ki jih lahko mnogo bolje uresničujemo, če organiziramo predšolsko vzgojo. Te štiri sestavine so: edukacija, zdravje, socialni kapital in enakost. $Z$ vlaganjem v organizirano predšolsko vzgojo te štiri sestavine krepimo, z njihovo močjo dosežemo ekonomsko rast, vse skupaj

\footnotetext{
${ }^{78}$ E. A. Doryan, K. C. Gautam, W. H. Foege, n. d.

${ }^{79}$ Enrique V. Iglesias and Donna E. Shalala, Narrowing the Gap for Poor Children, v: E. Eming Young (ur.), n. d.

${ }^{80}$ E. V. Iglesias, D. E. Shalala, n. d.

${ }^{81}$ Jacques van der Gaag, From child development to human development, v: E. Eming Young (ur.), n. d.
} 
pa vodi v razvoj človeštva. Avtor zagovarja investicije v organizirano predšolsko vzgojo in trdi, da te investicije predstavljajo investicijo v prihodnost.

V naslednji sliki predstavljamo, kako si avtor zamišlja povezanost organizirane predšolske vzgoje z razvojem človeštva.

\section{Kvalitetni predšolski programi}

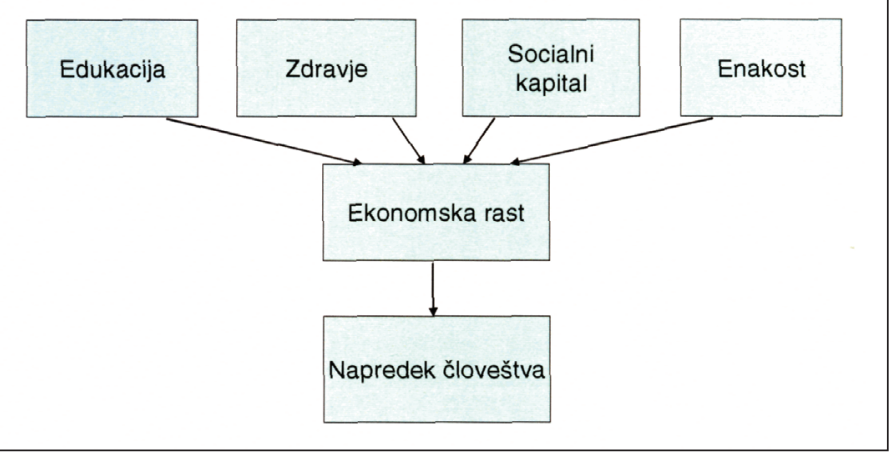

Slika 4: Povezanost organizirane predšolske vzgoje z razvojem človeštva. ${ }^{82}$

Pri tem avtor poudarja, da se dolgoročni učinki organizirane predšolske vzgoje pri otrocih, ki so vanjo zgodaj vključeni, če je ta kvalitetna in dovolj obsežna, kažejo v večji uspešnosti teh otrok kasneje v življenju. Predšolski programi prav tako lahko pripomorejo $\mathrm{k}$ boljši zdravstveni oskrbi otrok, kar je ponovno dokazljivo povezano $\mathrm{z}$ boljšim zdravstvenim stanjem kasneje v življenju. Mnoge študije o učinkih organizirane predšolske vzgoje dokazujejo spremembe na področju socialnega razvoja, obstajajo pa tudi dokazi, da dobri predšolski programi zmanjšujejo možnost asocialnega in kriminalnega vedenja kasneje v življenju. ${ }^{83}$ Schweinhart in drugi poročajo, da je na vsakih tisoč dolarjev, ki so vloženi v predšolske programe, najmanj 7160 dolarjev (po prilagojeni vrednosti zaradi inflacije) povrnjenih družbi. Ta izračun temelji na finančnih stroških, ki jih ima družba zaradi prestopništva, dopolnilnega izobraževanja, podpore nezaposlenim, v primerjavi

\footnotetext{
${ }^{82}$ Povzeto po: J. Van der Gaag, n. d.

${ }^{83}$ Lawrence J. Schweinhart, D. P. Weikart, A summary of significant benefits: The High Scope Perry Preschool study through age 27 (High Scope), 1993; Hirokazu Yoshikawa, Ling-term Effects of Early Childhood Program on Social Outcomes and Delinquency, The future of children 5/3 (1995), 51-75.
} 
s stroški, ki jih družba vloži v kvalitetne predšolske programe. Ekonomska analiza predpostavlja tudi višje davčne dajatve, ki jih bodo absolventi kvalitetnih predšolskih programov vračali državi.

Enakost je seveda močno povezana z vsemi predhodnimi komponenta$\mathrm{mi}$, vendar je tu potrebno poudariti, da organizirana predšolska vzgoja lahko zmanjša prikrajšanost revnih otrok tako na nivoju prehrane in zdravja kot tudi na nivoju kognitivnega in socialnega razvoja. To pa posledično kasneje $\mathrm{v}$ odraslosti vodi $\mathrm{k}$ bolj enakim možnostim. Boljša izobrazba in zdravje namreč dokazano vodita $\mathrm{k}$ boljšim dohodkom. Podatki pa tudi kažejo, da imajo države, ki imajo enakomernejšo distribucijo dohodkov, boljše zdravstveno stanje. ${ }^{84}$

Avtor tudi opozarja, da so učinki organizirane predšolske vzgoje vidni na treh nivojih: na nivoju otroka, odraslih in na nivoju širše družbe. Podrobneje pa jih predstavljamo v preglednici $4 \mathrm{v}$ nadaljevanju.

Podatki so zanimivi prav zaradi širšega uvida v umeščenost učinkov organizirane predšolske vzgoje, ki ga avtor osvetljuje. Po vsej verjetnosti pa se širša družbena skupnost vse premalo zaveda tega širšega poslanstva. Na nivoju ozaveščanja tega poslanstva bo v prihodnje potrebno postoriti še marsikaj, posebej še v pogojih, ko o razvoju organizirane predšolske vzgoje odločajo posamezniki in interesne skupnosti na lokalnem nivoju, ki lahko vidijo veliko več koristi v naložbah v infrastrukturo kot pa v predšolsko vzgojo.

$\mathrm{Na}$ koncu ob analizi virov, ${ }^{85}$ ki govorijo o investicijah v kvalitetno organizirano predšolsko vzgojo, lahko povzamemo vse koristi kvalitetne predšolske vzgoje v naslednje ugotovitve:

- prej ko začnemo z intervencijo, bolje je;

- programi morajo biti kvalitetni;

- usposabljanje osebja je začetek vseh dejavnosti v tej smeri;

- vključevanje staršev je nujno potrebno, njihova mnenja je potrebno upoštevati;

- predšolska vzgoja mora biti integrirana tudi z drugimi uslugami (npr. zdravstvenimi, s prehrano ipd.);

- vlade morajo spoznati, da je lahko organizirana predšolska vzgoja katalizator za spremembe oziroma da lahko investicije v organizirano predšol-

\footnotetext{
${ }^{84}$ Deaton, navedeno po: Jacques van der Gaag, n. d., 71.

${ }^{85}$ Jacques van der Gaag; L. B. Tarullo; K. Scott-McDonald; R. G. Myers; S. Kirpal; E. V. Iglesias, D. E. Shalala; E. A. Doryan, K. C. Gautam, W. H. Foege, v: M. E. Eming Young (ur.): From Early Child Development to Human Development, Investingin ourchild future, Washington D. C.2002.
} 
sko vzgojo prinesejo spremembe pri otrocih, v mnenju skupnosti o pomenu izobraževanja ipd.;

- trenutni stroški prinašajo dobrobit v prihodnosti, zato se investicije v organizirano predšolsko vzgojo za družbo izplačajo na račun kasnejšega ekonomskega varčevanja;

- birokratska razdrobljenost in delitev vladnih sektorjev upočasni celovito zadovoljevanje potreb otrok in njihovih družin;

- večja ko je razdalja med odločitvijo in učinkom, težje je narediti dobre odločitve, kar zanesljivo velja tudi za organizirano predšolsko vzgojo, ki ima svoje učinke vidne lahko šele v naslednji generaciji in so lahko tudi bolj široko razpršeni;

- kvalitetna predšolska vzgoja vodi $\mathrm{k}$ takojšnjim in merljivim dosežkom na področju otrokovega razvoja, predvsem kognitivnega in socialnega;

- kvalitetna predšolska vzgoja vodi $\mathrm{k}$ trajnim kognitivnim in socialnim koristim za otroka oziroma bodočega državljana;

- učinki kvalitetne organizirane predšolske vzgoje so vidni pri vseh otrocih, posebej močno pa pri otrocih iz socialno ogroženih okolij;

- najbolj pomembno učenje v predšolski dobi je tisto, ki se nanaša na aspiracije, uresničevanje nalog in vztrajnost, socialne spretnosti, razvijanje odgovornosti in pridobivanje občutka učinkovitosti.

In končno nas stari afriški pregovor uči, da je potrebna za vzgojo otroka cela vas. V današnjem času bi rekli kar globalna vas! 


\begin{tabular}{|c|c|c|c|c|}
\hline $\begin{array}{l}\text { Koristi or- } \\
\text { ganizirane } \\
\text { predšolske } \\
\text { vzgoje }\end{array}$ & Izobraževanje & Zdravje & Socialni kapital & Enakost \\
\hline $\begin{array}{l}\text { Za otroke (ta- } \\
\text { koj) }\end{array}$ & $\begin{array}{l}\text { večja inteli- } \\
\text { gentnost, boljše } \\
\text { praktično sk- } \\
\text { lepanje } \\
\text { boljša koordi- } \\
\text { nacija oči-roke } \\
\text { boljši sluh in } \\
\text { govor } \\
\text { boljša priprava } \\
\text { na branje } \\
\text { manj ponavl- } \\
\text { janja in izpada } \\
\text { iz šole } \\
\text { porast šolanja }\end{array}$ & $\begin{array}{l}\text { manj bolehnos- } \\
\text { ti, umrljivosti, } \\
\text { podhranjenos- } \\
\text { ti, nasilja nad } \\
\text { otroki } \\
\text { boljša higiena } \\
\text { in zdravstvena } \\
\text { nega }\end{array}$ & $\begin{array}{l}\text { boljše mnenje o } \\
\text { sebi, boljša so- } \\
\text { cialna prilago- } \\
\text { jenost } \\
\text { manj agre- } \\
\text { sivnosti } \\
\text { več sodeloval- } \\
\text { nosti } \\
\text { boljše vedenje v } \\
\text { skupinah, boljše } \\
\text { sprejemanje in- } \\
\text { stitucij }\end{array}$ & $\begin{array}{l}\text { zmanjšuje pri- } \\
\text { manjkljaje, ki } \\
\text { nastajajo zaradi } \\
\text { revščine } \\
\text { izboljšuje stanje } \\
\text { prehranjenosti, } \\
\text { kognitivni, so- } \\
\text { cialni razvoj in } \\
\text { zdravje }\end{array}$ \\
\hline $\begin{array}{l}\text { Za odrasle } \\
\text { (dolgoročni } \\
\text { učinki) }\end{array}$ & $\begin{array}{l}\text { visoka produk- } \\
\text { tivnost } \\
\text { stopnjevan- } \\
\text { je kognitivnega } \\
\text { razvoja } \\
\text { večja uspešnost } \\
\text { (boljše službe, } \\
\text { višji dohodki) } \\
\text { večja skrb } \\
\text { za otroke in } \\
\text { družinsko } \\
\text { zdravje } \\
\text { bolǰ̌e ekonom- } \\
\text { sko stanje }\end{array}$ & $\begin{array}{l}\text { izboljšano raz- } \\
\text { merje med } \\
\text { višino in težo } \\
\text { manj infekc- } \\
\text { ij in kroničnih } \\
\text { obolenj }\end{array}$ & $\begin{array}{l}\text { višja samozavest } \\
\text { boljša social- } \\
\text { na kompetenca, } \\
\text { motivacija, spre- } \\
\text { jemanje norm in } \\
\text { vrednot } \\
\text { manj } \\
\text { prestopništva } \\
\text { in kriminalnega } \\
\text { obnašanja }\end{array}$ & $\begin{array}{l}\text { izenačevanje } \\
\text { možnosti pri } \\
\text { izobraževanju, } \\
\text { zdravju in pri- } \\
\text { hodkih }\end{array}$ \\
\hline
\end{tabular}




\begin{tabular}{|c|c|c|c|c|}
\hline $\begin{array}{l}\text { Koristi or- } \\
\text { ganizirane } \\
\text { predšolske } \\
\text { vzgoje }\end{array}$ & Izobraževanje & Zdravje & Socialni kapital & Enakost \\
\hline $\begin{array}{l}\text { Za družbo v ce- } \\
\text { loti }\end{array}$ & $\begin{array}{l}\text { večja socialna } \\
\text { kohezija } \\
\text { manj revščine in } \\
\text { kriminala } \\
\text { manjša rodnost } \\
\text { povečano spre- } \\
\text { jemanje novih } \\
\text { tehnologij } \\
\text { okrepitev } \\
\text { demokratičnih } \\
\text { procesov } \\
\text { povišanje } \\
\text { ekonomskega } \\
\text { razvoja }\end{array}$ & $\begin{array}{l}\text { večja produk- } \\
\text { tivnost } \\
\text { manj odsotnos- } \\
\text { ti z dela } \\
\text { večji prihodki }\end{array}$ & $\begin{array}{l}\text { izboljšana raba } \\
\text { socialnega ka- } \\
\text { pitala } \\
\text { poudarjanje in } \\
\text { poviševanje so- } \\
\text { cialnih vrednot }\end{array}$ & $\begin{array}{l}\text { reduciran- } \\
\text { je revščine in } \\
\text { kriminala } \\
\text { boljše socialno } \\
\text { zdravje } \\
\text { poboljšanje } \\
\text { socialne } \\
\text { pravičnosti } \\
\text { višja in trajna } \\
\text { ekonomska rast }\end{array}$ \\
\hline
\end{tabular}

Preglednica 4: Koristi organizirane predšolske vzgoje za otroke, odrasle in družbo v celoti. ${ }^{86}$

Že v osemdesetih in devetdesetih letih 20. stoletja so bili torej zbrani tudi raziskovalni dokazi, ki so utrdili pomen zdravega razvoja v predšolskem obdobju in na začetku šolanja za razvoj otrokovih fizičnih, kognitivnih, čustvenih in socialnih sposobnosti, in tudi dokazi, da se lahko z investicijami v vzgojno-izobraževalne programe v tem obdobju izognemo ali vsaj ublažimo razvojne probleme. Raziskave o kratkoročnih in dolgoročnih učinkih organizirane predšolske vzgoje so prav tako izpostavile potrebo po visoko kvalitetni predšolski vzgoji, saj je le na ta način zagotovljen pozitiven vpliv na kakovost kasnejšega razvoja in življenja. Še več, rezultati raziskav so potrdili, da imajo le visoko kvalitetni predšolski programi temeljne, globinske in dolgoročne učinke za otrokov razvoj. ${ }^{87}$ Poudarek pri tej trditvi je na kvalitetnih programih in na dejstvu, da se vplivi kažejo na različnih področjih razvoja. Vpliv visoko kvalitetnih programov se je dokazal za vse otroke, najbolj pa za tiste, ki prihajajo iz socialno ogroženih okolij. Ti dokazi so se v zadnjih nekaj letih še povečali in tako utrdili njihovo kredibilnost. Postopno vlade spoznavajo nujnost podpiranja visoko kvalitetnih programov za vse predšolske otroke in tudi za njihove družine. Vse

\footnotetext{
${ }^{86}$ Povzeto po: J. Van der Gaag, n. d.

${ }^{87}$ L. J Schweinhart, D. P. Weikart, Evidence that Good Early Childhood Programmes Work, Phi Delta Kappan 66 (1985), 545-551
} 
bolj je prisotno spoznanje, da visoko kvalitetni programi za vse predšolske otroke lahko vodijo v večji napredek družbe kot celote.

Sodobne raziskave nedvoumno dokazujejo vpliv kvalitetnih programov za otroke (boljša uspešnost v šoli, višja stopnja izobrazbe, boljše zdravje, manj asocialnega obnašanja in kriminala, manjša depriviranost socialno ogroženih otrok). Dokazani pa so tudi pozitivni vplivi kvalitetnih predšolskih programov na nivo dosežene izobrazbe, na zdravstveno stanje, socialni kapital, zagotavljanje enakosti, vse to pa prispeva k večji ekonomski rasti in razvoju družbe in človeštva v celoti. ${ }^{88}$

Vseeno pa bi bilo potrebno ugotoviti, kolikšen del javnih investicij v razvoj in učenje je namenjen temu obdobju. Raziskava, ki je potekala v $12 \mathrm{dr}-$ žavah $\mathrm{ZDA}^{89}$ opozarja, da je javna poraba za otroke v kasnejših letih življenja mnogo višja od tiste v najzgodnejših letih in to kljub dejstvu, da se najbolj pomemben del razvoja odvija v prvih letih življenja. Bennett ${ }^{90}$ poroča, da ZDA namenjajo le $4 \%$ javnih investicij v obdobje, ko se formira $85 \%$ otrokovih možganskih struktur. Ti rezultati kažejo, da se mnogo večji poudarek daje investicijam v formalno izobraževanje od šestega leta dalje. $\mathrm{Ob}$ tem se pozablja, da so prav nizka vlaganja v zgodnja leta življenja lahko razlog za zaostanke v razvoju, ponavljanje in izpad iz rednega šolanja. Ti pojavi pa spet povišujejo stroške oziroma javno porabo za izobraževanje v poznejših letih življenja in onemogočajo investicije v zgodnejši razvoj.

\footnotetext{
${ }^{88} \mathrm{~J}$. Van der Gaag, n. d.

${ }^{89}$ Bruner, navedeno po: Emily Vargas-Baron,Planning Policies for Early Childhood development: GuidelinesforAction-TheLife-CycleApproachtoECDPolicyPlanning,MaterialsforGlobalLeadersGroup, 2007. ${ }^{90}$ John Bennett, Public policy in Early Childhood in Europe, 6 challenges for the coming years (uvodni referat), EECERA Conference Stavanger (september 2008), 3-6.
} 


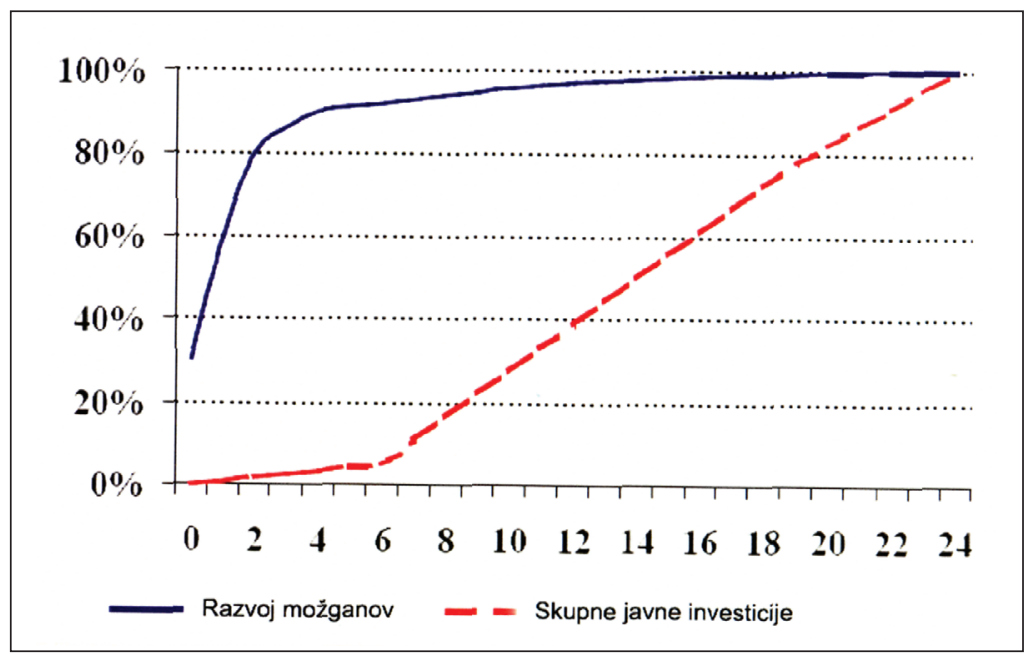

Slika 5: Rast možganov in javne investicije, namenjene otrokom. ${ }^{91}$

Investicije $\mathrm{v}$ učenje in razvoj $\mathrm{v}$ najzgodnejšem obdobju dokazuje tudi Nobelov nagrajenec za ekonomijo Heckman, ki je razvil model ekonomske upravičenosti investiranja $\mathrm{v}$ družine in servise za najmlajše otroke. Iz krivulje na sliki 6 je razvidno, da je investicija tem bolj povrnjena, čim prej začnemo vlagati v človeški kapital. Heckman med drugim dokazuje, da politike, ki ogroženim družinam omogočajo dostop do vzgojno-izobraževalnih virov, skrbijo za zniževanje neenakosti in za dvig produktivnosti hkrati. Opozarja tudi na to, da je poleg kognitivnih sposobnosti nujno razvijati emocionalno stabilnost, samoregulacijo, socialnost in motivacijo za učenje. Če otrok za razvoj teh sposobnosti v družini nima spodbudnega okolja, potem naj to nalogo opravijo programi za otroke. Posebej pa bi vladne politike morale po njegovem mnenju okrepiti servise za ogrožene družine $\mathrm{z}$ otroki in ponujati programe za otroke in njihove starše.

${ }^{91}$ Bruner et al., povzeto po: E. Vargas-Barón, n. d. 


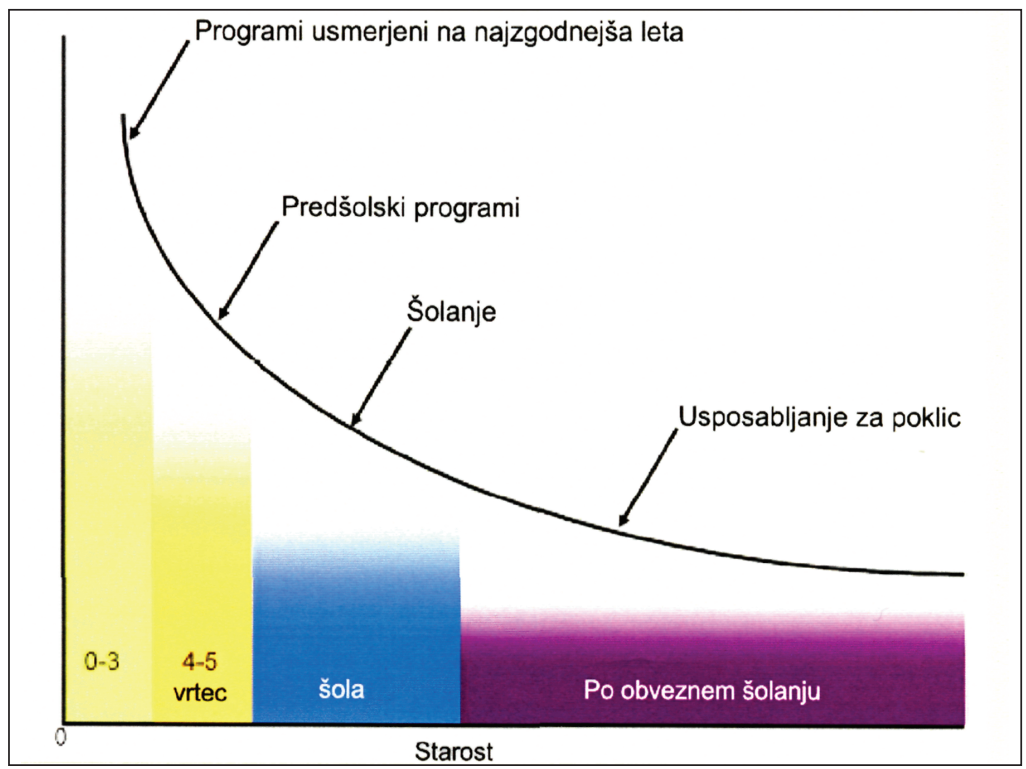

Slika 6: Heckmanova krivulja: Prej ko začnemo z vlaganjem v človeške vire, višji je povratek. ${ }^{92}$

\section{Kakovost $\mathrm{z}$ vidika izvajalcev}

Težko bi trdili, da vrtec in zaposleni v njem ali kdorkoli od drugih izvajalcev organizirane predšolske vzgoje ne težijo h kakovosti njihovih uslug in dela, čeprav niso neposredni uporabniki teh uslug. Obenem pa nam vsakodnevna praksa dokazuje, da je njihova kakovost različna. Kje so razlogi za te razlike, kako ugotavljamo kakovost izvajalcev in kako jo spreminjamo, je naslednje vprašanje, s katerim se ukvarja sodobna predšolska vzgoja.

Podobno kot drugi sodobni pedagoški koncepti, tudi na tem področju prihaja do redefiniranja in usklajevanja s sodobnimi zahtevami. Tradicionalni sistem preverjanja kakovosti je predstavljal zunanji nadzor nad kakovostjo, ki je bil ponavadi obremenjen $s$ subjektivnimi ocenami in kvantitativnimi kazalci kakovosti. Osnovni namen teh sistemov je bila zunanja kontrola in regulacija, ki bo ustrezala zakonodaji in normativnim aktom, zato govorimo o kontrolno-regulativnih modelih. Ponavadi so ti modeli v svoji zaključni fazi vodili v določene sankcije. Sodobni modeli pa temelji-

${ }^{92}$ Heckman, povzeto po: J. Bennett, n. d. 
jo na podpiranju institucije in izvajalcev $k$ avtonomnemu iskanju ustreznih sprememb in razvijanju strokovne odgovornosti.

Do sprememb iz kontrolno-regulativnih k vse bolj avtonomnim in razvojno usmerjenim modelom na področju ugotavljanja kakovosti je prišlo $s$ procesom demokratizacije in decentralizacije na področju šolstva. $\mathrm{V}$ tem procesu se veča avtonomnost izvajalcev, pa tudi stopnja soodločanja in vplivanja uporabnikov na odločitve, povezane s kakovostjo. Država postopno izgublja status edinega kontrolorja kakovosti in prenaša to funkcijo na javnost. Na ta način uresničuje princip lastništva skupnosti nad javnim šolskim sistemom. ${ }^{93}$ Gre pravzaprav za spreminjanje razmerja moči pri kontroli kakovosti: na eni strani jo država izgublja, na drugi strani pa jo uporabniki in izvajalci pridobivajo. Ko vrtec postaja bolj vpet v vodenje in odločanje, se spremeni nadzorovanje kakovosti. Vendar pa proces demokratizacije in decentralizacije ne ponuja izvajalcem vzgoje in izobraževanja samo vse več možnosti za odločanje, ampak tudi veliko več sprejemanja odgovornosti in tveganja. ${ }^{94}$ Sirec $^{95}$ meni, da je rast in razvoj vzgojno-izobraževalne institucije v smeri kakovostnih sprememb mogoča le ob ugodnih spodbudah iz okolja ter optimalni notranji motivaciji institucije in vseh strokovnih delavcev v njej za spremembe.

Vse bolj očitna postaja potreba po oblikovanju takšnih modelov ugotavljanja kakovosti, ki bodo hkrati z ugotavljanjem kakovosti ali posameznih elementov, ki jo sestavljajo, spodbujali k strokovnemu razvoju. To pa velja tako za sisteme notranjega ocenjevanja (samoocenjevanja) kot tudi za sisteme zunanjega ocenjevanja, ki se $\mathrm{v}$ sodobnih pristopih pogosto dopolnjujejo. Ugotavljanje kakovosti namreč ni namenjeno le uvidu v stanje pojava, ampak je usmerjeno tudi $\mathrm{k}$ analizi in ukrepom za preraščanje problemov, tu pa izvajalci potrebujejo tudi zunanjo strokovno pomoč.

Med sistemi in načini zagotavljanja kakovosti se uveljavljajo tudi drugi načini razvijanja kakovosti. Med njimi je zanesljivo sistem spreminjanja kulture institucije. Sistem temelji na predpostavki, da je spreminjanje kakovosti institucije pogojen s kulturnimi vrednotami in normami, ki naj bi jih dosegli v procesu spreminjanja. Tako naj bi v procesu spreminjanja dosegli naslednje cilje:

\footnotetext{
${ }^{93}$ International step by step association, Step by Step Program and Teacher Standards for Preschool and Primary Grades, New York, Budapest, Amsterdam 2003.

${ }^{94}$ Carl D. Glickman, Supervision in Transition, Alexandria 1992.

${ }^{95}$ Alojz Širec, Slovenska šolska inšpekcija in kakovost dela šol, Sodobna pedagogika 51/4 (2000), $106-124$.
} 


\begin{tabular}{|l|l|}
\hline \multicolumn{1}{|c|}{ Skupni cilji } & \multicolumn{1}{c|}{ Vemo, kam gremo } \\
\hline Odgovornost za uspeh & Moramo uspeti \\
\hline Kolegialnost & V tem smo skupaj \\
\hline Neprestano izboljševanje & To je lahko boljše \\
\hline Vseživljenjsko učenje & Vsi se neprestano učimo \\
\hline Pripravljenost na tveganje & $\begin{array}{l}\text { Ko poskušamo nekaj novega, se učimo, pa } \\
\text { četudi delamo napake }\end{array}$ \\
\hline Podpora & Vedno je kdo, ki nam bo pomagal \\
\hline Medsebojno spoštovanje & Vsak lahko kaj prispeva \\
\hline Odprtost & O naših razlikah se lahko pogovarjamo \\
\hline Proslavljanje in humor & Dobro se počutimo \\
\hline
\end{tabular}

Preglednica 5: Cilji v procesu spreminjanja vrtca. ${ }^{96}$

Drug pristop, ki naj bi prispeval k spreminjanju kakovosti, pa je v novi paradigmi vodenja institucije, ki vodi $\mathrm{k}$ večji avtonomnosti, podpiranju in izkoriščanju človeških virov v instituciji ter odpiranju k zainteresiranim skupinam in posameznikom ter njihovemu aktivnemu vključevanju v oblikovanje politike posamezne institucije. Prav spreminjanju načina vodenja namenjajo nekateri avtorji pomembno funkcijo v doseganju višje kakovosti. ${ }^{97}$ In končno naj bi $\mathrm{k}$ višji kakovosti prispevali tudi drugačni pristopi $\mathrm{k}$ profesionalnemu razvoju vzgojitelja. Ob vsem naštetem pa velja poudariti, da se vsi ti pristopi običajno močno prepletajo in dopolnjujejo.

\section{Kako ocenjujemo kakovost $\mathrm{v}$ organizirani predšolski vzgoji}

Obstajajo različni načini študija različnih kazalcev kakovosti. Katzova opozarja, ${ }^{98}$ da v večini strokovnih gradiv, ki se ukvarjajo s vprašanji kakovosti v vrtcih, najdemo t. i. »pristop od zgoraj navzdol«, ki opredeljuje vrtec $\mathrm{z}$ značilnostmi, kot jih vidimo odrasli (razmerje med otroki in odraslimi, kvalifikacija in stalnost osebja, kakšna je oprema, značilnosti interakcije med otroki in odraslimi, odnosi). Vse te kazalce je mogoče neposredno opazovati. Po njenem mnenju lahko pričakujemo, da ti kazalci v resnici napovedujejo učinke vrtca.

\footnotetext{
${ }^{96}$ Stoll, Fink, povzeto po: E. Pranckuniene, M. Vildžiuniene, K. B. Walsh, Step by Step to School Improvement, Workshop materials, ISSA 2002.

${ }^{97}$ M. Fullan, Interview, The Journalof the National StaffDevelopment Council24/1 (2009), 55-58.

${ }^{98}$ L. G. Katz, Perspectives on the Quality of Early Childhood Programs (referat na konferenci EECERA), Wurchester 1992.
} 
Avtorica hkrati opozarja, da je potrebno osnovni učinek programa vrednotiti predvsem $z$ vidika, ki ga imenuje »od spodaj navzgor «, to je iz otroka oziroma tega, kakšna je izkušnja vsakega od otrok v vrtcu skozi tedne in mesece v vrtcu. Takšna ocena bi prinesla »ugibanje« o otrokovi subjektivni izkušnji v vrtcu. Ob tem bi se najverjetneje spraševali po tem, kakšni bi bili otrokovi odgovori na vprašanja o tem:

- Ali ima občutek, da ga vzgojiteljica sprejema in ima občutek, da je vključen v kolektiv?

- Ali ga jemljejo resno?

- Ali ga vrstniki odklanjajo ali sprejemajo?

- Ali so dejavnosti zanj zanimive, smiselne, zabavne?

- Ali je ponavadi vesel, da je v vrtcu?

Če bi na večino teh in podobnih odgovorov odgovorili pritrdilno, bi lahko predvidevali, da je vrtec cenjen z vidika otrok.

Ocena kakovosti naj bi po mnenju Katzove vključevala tudi vidik, ki ga imenuje »od zunaj-navznoter«. Ta ocena naj bi predvsem opozarjala na odnose med starši in vzgojitelji in to s perspektive obeh. Odnose pa naj bi ocenjevali z vidika spoštovanja, sprejemanja, odprtosti, vključenosti, tolerance ... Visoko kakovost $s$ te perspektive je še posebej težko doseči v primerih, ko starši in strokovno osebje v vrtcu ne izhajajo iz iste kulture. V teh primerih mora vzgojno osebje pridobiti dodatna znanja in strokovno pomoč.

Naslednji vidik, ki je mogoč pri ocenjevanju kakovosti v vrtcu pa Katzova imenuje »notranji vidik «. Ta temelji na prepričanju, da ni mogoče doseči visoke kakovosti, če odnosi znotraj vrtca niso kvalitetni. V tem primeru je pomembno, kako se osebje med seboj podpira, kako medsebojno sodelujejo, se sprejemajo, si zaupajo in se spoštujejo.

Obstajajo pa seveda tudi drugi načini ocenjevanja kakovosti. Tako je npr. preverjanje dokumentov in poročil primerno za ugotavljanje kazalcev, ki jih določajo predpisi. Poročila osebja o vidikih programa, ki jih ni mogoče opazovati, so prav tako vir informacij. Vprašalnik za starše in vzgojno osebje nam daje informacije o tem, kako dobro se program odziva na njihove potrebe. Toda le preko opazovanja otrok in vzgojnega osebja v oddelku lahko ocenjujemo uvajanje kurikula, stil medsebojne interakcije in ustreznost fizičnega okolja.

Intervjuji ali ankete $z$ vodstvom vrtca, starši in osebjem nam dajo informacije o načrtovanju kurikula, komunikaciji med osebjem in starši, so- 
delovanjem s starši, profesionalnem izpopolnjevanju osebja, evalvacijskih postopkih ipd. $Z$ analizo dokumentov pa dobimo informacije o programski filozofiji, načrtovanju kurikula, administrativni politiki in postopkih, kvalifikaciji osebja, zagotavljanju zdravja in varnosti.

$\mathrm{V}$ nekaterih primerih se isti instrumenti in načini zbiranja informacij uporabljajo tako za primer akreditacije ali certifikacije kot tudi v primeru samoevalvacije. Pri tem je samoevalvacija predvsem namenjena spodbujanju izboljševanja in razvoja institucije. Viri informacij in njihovo ugotavljanje so lahko kvantitativni in kvalitativni. Prav z dopolnjevanjem obeh pristopov pa se lahko pridobi bolj celovito sliko problema, ki ga proučujemo.

\section{Kazalci kakovosti organizirane predšolske vzgoje}

Več kot je bilo dokazov o tem, da kvalitetna organizirana predšolska vzgoja pozitivno vpliva na otrokov razvoj, bolj je bilo tudi jasno, da leži ključ vseh teh ugotovitev v visoki kakovosti. Hkrati z raziskovanjem učinkov organizirane predšolske vzgoje je bila strokovna javnost vse bolj usmerjena $\mathrm{k}$ vprašanju, kako identificirati in ocenjevati kakovost. ${ }^{99}$ Pri tem je temeljnega pomena ugotoviti, kateri so osnovni kazalci kvalitetnega izobraževanja ter kako programe opazovati in ocenjevati. ${ }^{100}$

Zato ni nič presenetljivega, da različni avtorji kakovost opredeljujejo na različne načine. Pri tem nekateri raziskovalci ocenjujejo celostno kakovost programov. ${ }^{101}$ Takšna celostna ocena kakovosti skuša zajeti splošno klimo programa. Hkrati lahko ugotovimo, da so bili programi, ki so bili ocenjeni z visoko globalno oceno kakovosti, povezani s številnimi pozitivnimi učinki na otrocih kot so npr. višji nivo socialne kompetence, višji razvojni nivo igre, boljše sposobnosti samoregulacije, manj problemov v šoli. Takšna globalna ocena temelji na prepričanju, da gredo dobre stvari skupaj. Če bi to skušali povedati preprosteje, bi lahko rekli, da je »boljši vrtec« boljši za otroka. Seveda pa pojem »boljši vrtec« tudi v tem primeru predstavljajo različni kazalci kakovosti, kot so npr.:

\footnotetext{
${ }^{99}$ H. McGurk, M. Caplan, E. Hennessy, P. Moss, Controversy, Theory and Social Context in Contemporary Day Care Research, Child Psychology Psychiatry 34/1 (1993), 3-23; Deborah A. Phillips, Quality in child care: What does a research tell us?, Washington D. C. 1993.

${ }^{100}$ Cristine Pascal, Under fives in infant classrooms, Stoke on Trent, London 1990.

${ }^{101}$ D. L. Vandell, Carol P. Powers, Day care quality and children's free play activities, American Journal of Orthopsychiatry 53 (1983), 493-500; C. Howes, M. Olenick, Family and child care influences on toddler compiliance, Child development 57 (1986), 202-216; Thelma Harms, Richard M. Clifford, Early Childhood Environment Rating Scale, New York 1980; Kathleen McCartney, Effects of Quality of Day-care Environment on children's language development, Developmental Psychology 20 (1984), 244-260; D. Phillips, K. McCartney, S. Scarr, Child care quality and children's social development, Developmental Psychology 23 (1987), 537-543.
} 
- razmerje med številom odraslih in otrok v oddelku;

- število otrok v skupini;

- usposobljenost vzgojnega osebja;

- stalnost osebja;

- učni kontekst;

- stil komunikacije in interakcije na nivoju vzgojitelj-otroci ter vzgojiteljstarši;

- varnost;

- rutina in uravnoteženost $\mathrm{v}$ razporejanju aktivnosti ipd.

Drugi avtorji pa raziskujejo specifične vidike kakovosti, kot so:

- strukturni vidik, ${ }^{102}$

- dinamični, interakcijski ali procesni vidik, ${ }^{103}$

- kontekstualni vidik in vidik združenih učinkov kakovosti programa ter otrokovega domačega okolja. ${ }^{104}$

Bennett ${ }^{105}$ pa navaja naslednje vidike kakovosti:

- orientacijska kakovost, ki se ukvarja s pozornostjo, ki jo vlade namenjajo predšolskemu področju in proučuje njihove politike, zakonodajo, pravilnike ipd.;

- strukturna kakovost, ki je primarno vezana na odgovornost administracije, da zagotovi ustrezno fizično okolje za otroke (stavba, igrišče, pedagoški materiali, ki so na voljo), kakovost in usposobljenost osebja, ustrezno preizkušen kurikulum, ki zadeva vsa področja otrokovega razvoja, primerno razmerje med številom otrok in odraslih, ustrezne delovne po-

\footnotetext{
${ }^{102}$ Allison K. Clarke-Stewart, Linda May Fitzgerald, Irvine Christian P. Gruber, Children at home and in day care, Hillsdale, New Jersey 1984; C. Howes, J. Rubenstein, Determinants of Toddler's experience in day care: Age of entry and quality of settings, Child Care Quarterly 14 (1985), 140-151.

${ }^{103}$ D. Phillips, K. McCartney, S. Scarr, Bermuda Study, Report 1993; K. Špoljar, Analiza interakcija odgajatelj-dijete u svrhu podizanja kvalitete odgojno-obrazovnog rada u dječjim vrtičima, Studije i izvestaji, Zagreb 1986.

${ }^{104}$ A. K. Clarke-Stewart, C. P. Gruber, L. M. Fitzgerald, n. d.; C. Howes, Relations between Early Child Care and Schooling, Developmental Psychology 24, (1988), 53-57; K. McCartney, D. Philips, Motherhood and child care, v: Hay Birns, (ur.), Different faces of motherhood, New York 1988; S. J. Kontos, Day care quality, family background and children's development, Baltimore 1987; Susan J. Kontos, Richard Fiene, Child care quality, compliance with regulation and children's development: The Pennsylvania study, v: Phillips (ur), Quality in child care: What does research tell us?, Washington D. C. 1993.

${ }^{105}$ J. Bennett, Early Childhood Services in the OECD Countries, Innocenti working paper, UNICEF 2008.
} 
goje za osebje). Običajno na tej osnovi institucije dobijo licenco za delovanje;

- kakovost edukativnega koncepta in prakse, ki ga običajno usmerja okvirni nacionalni kurukulum s ključnimi cilji. Pri tem lahko pričakujemo, da bo te cilje lahko uresničevalo le visoko usposobljeno osebje. Primer tako oblikovanih ciljev za predšolske otroke so npr. cilji, ki jih predlaga Delors ${ }^{106}$ in jih lahko povzamemo v učenje zato, da bi bili, da bi delali, da bi se učili in da bi bili z drugimi. Tako zastavljeni cilji postavljajo otroka $\mathrm{v}$ središče pozornosti, zahtevajo otrokovo participacijo in eksperimentiranje, ki ju lahko omogočajo le usposobljeni vzgojitelji;

- interakcijska ali procesna kakovost, ki zadeva odnose med otroki, med otroki in vzgojitelji, med odraslimi v instituciji in izven nje;

- operativna kakovost, ki zadeva zlasti management, ki je osredinjen na lokalne potrebe, izboljševanje kakovosti in učinkovito timsko delo.

Večina raziskav o kakovosti institucionalne predšolske vzgoje je osredotočena na strukturne kazalce teh pogojev, le nekaj pa jih je usmerjenih tudi na procesne kazalce, še manj pa na kontekstualne vidike.

Ne glede na raznolikost $\mathrm{v}$ pristopih $\mathrm{k}$ opredelitvi kakovosti se pojem kakovost običajno uporablja za opis značilnosti predšolskega programa, okolja in pogojev, v katerih se izvaja, ter izkušenj, za katere na osnovi raziskovanj in prakse predvidevamo, da koristijo otrokovi rasti in razvoju.

Iz takšne opredelitve v organizirani predšolski vzgoji izluščimo dve skupni značilnosti kakovosti:

1) Razlikujemo dinamične (interakcijske) in statične (strukturne) značilnosti kakovosti.

2) Pomembna determinanta kakovosti organizirane predšolske vzgoje je tudi kontekst zunaj posameznega oddelka, ki ga predstavljajo pogoji in odnosi v instituciji ter zunaj institucije v širši skupnosti. Na kakovost torej ne gre gledati le na nivoju posameznega oddelka, ampak tudi na nivoju cele institucije in končno širše skupnosti.

Ob ugotovitvah o pomenu kakovostiv organizirani predšolskivzgoji pa se vse bolj srečujemo še s tremi medsebojno tesno povezanimivprašanji, in sicer:

1) Kateri so osnovni kazalci kvalitetne organizirane predšolske vzgoje?

2) Kako kakovost v organizirani predšolski vzgoji opazovati in ocenjevati?

3) Kako spreminjati (izboljšati) in zagotavljati kakovost?

${ }^{106}$ Jacques Delors, The treasure Within (The Delors report on education), Paris 1996. 


\section{Kakovost vzgojiteljev}

V sodobnih procesih na področju predšolske vzgoje se ne moremo izogniti tudi vprašanjem kakovosti vzgojiteljev. Vse bolj je prisotno spoznanje, da je napredek vrtca odvisen od tega, kaj in kako vzgojitelj dela v oddelku pa tudi izven njega $\mathrm{v}$ vrtcu in $\mathrm{v}$ javnosti in kako pojmuje svoje delo in vlogo. $\mathrm{V}$ nadaljevanju bomo pozornost namenili spremenjeni vlogi vzgojitelja ter evalviranju kakovosti njegovega dela, ki naj bi prispevala k njegovemu profesionalnemu razvoju in s tem spreminjanju kakovosti. Da bi se izognili nesporazumom ob pojmu strokovni razvoj, ki ga pogosto enačijo $s$ strokovnim znanjem v določeni stroki, bomo uporabljali pojem profesionalni razvoj.

\section{Sprememba kulture učenja in skrbi za otroke}

Če izhajamo iz trditve Fullana, ${ }^{107}$ da obstaja dvoje gibal v spreminjanju institucije na področju vzgoje in izobraževanja, to je spreminjanje kulture institucije in spreminjanje kulture učenja, potem za področje organizirane predšolske vzgoje velja k spreminjanju kulture učenja dodati še spremembo skrbi za otroke. Prehod iz tradicionalnega tovarniškega modela institucije v institucijo kot ustvarjalno delavnico ter iz transmisijskega kurikula $\mathrm{k}$ transformacijskemu kurikulu, ki vključuje spreminjanje in učenje vseh (ne le otrok), je močno zaznamoval vlogo vzgojitelja v tem procesu, hkrati pa spremenil poglede na to, kaj je kakovost in kakovosten vzgojitelj. Eden od razlogov za spremembe leži v spremembah v sodobni družbi, ki zahtevajo človeka s povsem drugačnimi kompetencami kot pred desetletji. Spremenjeni cilji, ki so od mehaničnih načinov prešli na bolj kompleksne, so povzročili tudi spremembo standardov učenja in razvoja, po čemer so ocenjevali kakovost vzgojitelja. V zadnjih dvajsetih letih mora vzgojitelj razmišljati tudi o tem, kako pomagati otrokom pri razvijanju kritičnega mišljenja, reševanju problemov, odzivanju na spremembe v družbi, oblikovanju osnov za vseživljenjsko učenje, globljem razumevanju, prepoznavanju in spoštovanju razlik, ipd.

Sodobno pojmovanje vzgojiteljeve vloge se je v marsičem spremenilo in se od preprostih pojmovanj, ki zajemajo transmisijo izdelanih in poenostavljenih vsebin posameznih disciplin ter oblikovanja in izgrajevanja otrokovih sposobnosti in spretnosti, premika k razvitim pojmovanjem, ki njegovo vlogo pojmujejo kot:

${ }^{107}$ Dennis Sparks, Change agent, The Journal of the National Staff Development Council 24/1 (2003), 55-58. 
I44 ORGANIZIRANA PREDŠOLSKA VZGOJA V IZZIVIH DRUŽBENIH SPREMEMB

- vodenje otroka $\mathrm{v}$ smeri proti ciljem in nudenjem ustrezne pomoči ob težavah ter

- spodbujanju rasti in razvoja s primernimi viri, izkušnjami, spodbudami, ki jih pripravi vzgojitelj. ${ }^{108}$

Sodobni pristopi vzgojitelju nalagajo drugačne vloge v oddelku, v vrtcu in $\mathrm{v}$ javnosti. Jalongo in Isenbergova ${ }^{109}$ navajata naslednje vloge:

- reflektivni praktik,

- zagovornik otrok,

- specialist za otrokov razvoj,

- oblikovalec okolja,

- razvijalec kurikula,

- načrtovalec izobraževanja,

- evalvator,

- posredovalec in model,

- partner družinam,

- profesionalec,

- vodja oziroma upravljalec.

Že samo pogled na vsa opravila, ki naj bi jih obvladal, nam nedvoumno kaže, kako zahtevno in kompleksno je njegovo delo. Samo v oddelku, če je ta osredotočen na otroke, vzgojitelj igra različne med seboj zelo povezane vloge. Le za lažje razumevanje bomo posamične vloge, kot jih definirajo nekateri avtorji, ${ }^{110}$ prikazali ločeno.

\section{OdLOČAnJE}

Vzgojitelj vsak dan sprejema odločitve, ki vplivajo na to, kaj se otroci naučijo in kakšno mnenje imajo o sebi. V oddelku, ki je osredotočen na otro-

\footnotetext{
${ }^{108}$ Prim. Barica Marentič Požarnik, Kako pomembna so pojmovanja znanja, učenja in poučevanja za uspeh kurikularne prenove (drugi del), Sodobna pedagogika 49/4 (1988), 256.

${ }^{109}$ M. R. Jalongo, J. P. Isenberg, Exploring Your Role - A Practitioner's Introduction to Early Childhood Education, Merrill 2000, IX.

${ }^{110}$ Judy Jablon, Creating Curriculum in Early Childhood, v: Mitchell, Davids (ur.), Exploration with young children: A curriculum guide from the Bank Street School of Education, Mt. Rainer, MD 1992, 121-132; Diane Trister Dodge, J. Jablon, Toni S. Bickart, Constructing curriculum for primary grades, Washington D. C. 1994; Laura E. Berk, Adam Winsler, Scaffolding Children's learning: Vygotsky and Early Childhood Education, 1995; Kate Burke Walsh, Na učenca osredotočena metodologija dela v 2., 3. in 4. razredu osnovne šole, Ljubljana 2003; Lilian G. Katz, Diane E. McClellan, Fostering Children's Social Competence: The teacher's role, Washington D.

C. 1997; M. R. Jalongo, J. P. Isenberg, n. d.
} 
ka, ima vzgojitelj možnost, da odloča o marsičem, o čemur ni odločal v oddelku z dominantno vlogo vzgojitelja. Pomembne odločitve so v tem primeru sprejemali ljudje, ki so bili v hierarhiji šolskega sistema nad njim, ali pa celo izven vrtca. Ko vzgojitelj začne verjeti v svoje profesionalno znanje, lahko cilje, ki so predpisani, uresničuje v skladu z otroki, ki jih ima v svojem oddelku. Vzgojitelj vsak dan odloča o tem:

- katere cilje bo izbral in pri tem ohranil celostni pristop pri razvoju,

- katere aktivnosti bo vključil, da bo učenje ob njih za otroke smiselno in osebno pomembno in da bo učenje integrirano,

- kako bo uredil učno okolje,

- katere materiale in sredstva bo omogočil uporabljati otrokom,

- kako bo organiziral potek dejavnosti skozi ves dan,

- kako bo otroke vključil v odločanje in kako bo v procesu pri njih razvijal sposobnost odločanja.

Sprejemanja odločitev se vzgojitelj nauči, ko začne v procesu sprejemanja odločitev zaupati svojim odločitvam in svojim sposobnostim.

\section{OlajŠEVANJE In SPODBUJANJE UČENJA}

Tavloga izhaja iz teorije izgradnjezidarskega odra oziroma pomoči otrokom v procesu njihovega učenja. Vzgojitelj otrokom lahko pomaga in olajša učenje in jim nudi zidarski oder z vprašanji, komentarji, problemi, izzivi, spodbudami, načrtovanimi in nenačrtovanimi problemskimi situacijami ipd. Tako vzgojitelj ustvarja pogoje za napredek v razvoju in pogoje za to, da otrok svoje znanje nadgradi. V tem procesu vzgojitelj išče odgovore na vprašanja o tem: - katere metode bo uporabil, da bo zadovoljil otrokove razvojne, individualne in kulturne potrebe in hkrati omogočil učenje ključnih pojmov in spretnosti ter razvoj sposobnosti,

- kako bo olajšal učenje različnim otrokom,

- kako bo upošteval pravice in potrebe otrok,

- kako bo otrokom pomagal interpretirati njihove izkušnje,

- kako bo grupiral otroke za učenje,

- katera vprašanja bo postavil in kako jih bo postavljal,

- kako bo odgovarjal na otrokova vprašanja,

- kako bo pomagal otrokom, da se bodo odzivali na svoje učenje,

- katere vire bo zagotavljal, da bo omogočal bogate učne izkušnje. 


\section{OPAZOVANJE IN SLEDENJE OTROKOVEMU UČENJU}

Vzgojitelj išče odgovore na vprašanja o tem, kakšni so otroci v njegovem oddelku in kako naj olajšuje in spodbuja njihov razvoj in učenje. ${ }^{11}$ Pri tem si odgovarja na vprašanja:

- kakšna znanja in spretnosti otroci že imajo,

- česa so se zmožni naučiti,

- kakšne učne stile imajo otroci,

- kakšni so interesi otrok,

- kako bo opazoval otroke in beležil njihov razvoj,

- katere vzorce otrokovih izdelkov bo zbiral, da bi lahko sledil otrokovemu razvoju,

- kako bo predstavil svoje videnje otrokovega napredka staršem,

- kako bo upošteval videnje staršev.

\section{Modeliranje}

Vzgojitelj s svojimi postopki v oddelku modelira načine odnosov, komunikacij, interakcij, ki jih otroci posnemajo, zato razmišlja tudi o naslednjih vprašanjih:

- kako bo zagotovil oddelčno klimo, ki bo temeljila na spoštovanju, skrbnosti in medsebojni pomoči,

- kako bo modeliral tehnike reševanja problemov,

- kako bo prepoznal in seznanjal otroke o njihovih močnih straneh,

- kako bo otrokom pomagal zgraditi skupnost otrok, ki bo osnova socialnemu učenju,

- kako bo modeliral odnos do učenja, napak, odgovornosti,

- kako bo sodeloval s starši in drugimi pomembnimi odraslimi iz otrokovega sveta, ipd.

Ob vsem tem naj bi vzgojitelj skrbel tudi za lastni profesionalni razvoj, saj se v sodobnem vrtcu učijo vsi. V tem procesu pa vzgojitelj ne sme ostati sam. Če parafraziramo Vigotskega, da učenje ni osamljeno potovanje, potem je tudi v primeru učenja vzgojitelja potrebno iskati socialne opore, ki podpirajo to učenje. $V$ ta namen pa je potrebno ustvariti ustrezno kulturo vrtca.

${ }^{111}$ D. T. Dodge, J. Jablon, T. S. Bickart, Constructing curriculum for primary grades, Washington D. C. 1994; K. B. Walsh, Creating child-centred classrooms, Children's Resources International in partnership With Open Society Institute 1997. 
Sodobna organizirana predšolske vzgoja spreminja tudi odnose med vzgojitelji, vzgojitelji in administracijo, vzgojitelji in starši ter odnose med institucijo in okoljem. Ti spremenjeni odnosi naj bi omogočali ustvarjanje spodbudne kulture vrtca, v kateri je mogoče imeti občutek lastništva nad tem, kar spreminjamo in $s$ tem zagotoviti uspešnost sprememb. Skupno odločanje, timsko delo in profesionalna združenja postajajo nujnost, ki zahteva, da vzgojitelji razmislijo tudi o evalvaciji svojega dela ter o svojem profesionalnem razvoju.

Sodobne reforme slonijo na spoznanju, da je njihov uspeh odvisen predvsem od vzgojiteljeve avtonomije, profesionalnosti in strokovne odgovornosti, zato skušajo preseči od zgoraj vsiljene rešitve, ki so zgodovinsko gledano, prinašale neuspeh. Utrdilo se je spoznanje, da vzgojitelji filtrirajo sporočila kurikularnih dokumentov, zato je potreba po razvijanju vzgojiteljevrazmišljujočih praktikov in profesionalcev vse bolj aktualna. Značilno za profesionalce pa je, da se znajo na razmišljajoč način učiti iz svoje prakse. ${ }^{112}$

V zadnjih letih so se tudi močno spremenila spoznanja o tem, kako se učijo odrasli. Vse bolj se poudarja pomen njihovega aktivnega vključevanja v prizadevanja za stalni razvoj, da imajo možnost graditi od točke, kamor so v svojem razvoju že prišli, da imajo možnost deliti svoje izkušnje in jih v dialogu potrditi, zagovarjati in tudi spremeniti, če je to potrebno, da delajo v kulturi sodelovanja, da so v tem procesu podprti ipd. Nadvse pomembno pa je, da se spremeni tudi pojmovanje in oblikovanje odnosa med teorijo in praktičnimi izkušnjami. Marentič Požarnikova opozarja na raziskave, $\mathrm{v}$ katerih so dokazali, da se vzgojitelj v oddelku odloča predvsem na podlagi situacijskega razumevanja, praktičnega znanja in intuitivno. To pa pomeni, da se mora znati učiti iz izkušenj, o njih razmišljati, jih poglabljati in jih povezovati med seboj in s teoretičnimi osnovami. ${ }^{113}$

Vzgojitelji imajo tudi svoj lasten pogled na to, kaj je dobra praksa. Zato med vzgojitelji v praksi obstaja precejšnja razlika v njihovem pojmovanju kakovosti. Marentič Požarnikova ${ }^{114}$ opozarja, da subjektivna pojmovanja in implicitne teorije v veliki meri določajo pedagogovo ravnanje, vsakdanje odločanje v učnih situacijah, rezultate in predstavljajo nekakšen »filter«, skozi katerega vzgojitelj bere zahteve v kurikulu, se odloča za učne meto-

\footnotetext{
${ }^{112}$ Schon, navedeno po: B. Marentič Požarnik, Profesionalizacija izobraževanja učiteljev - nujna predpostavka uspešne prenove, Vzgoja in izobraževanje 31/4 (2000), 4-11.

${ }^{113}$ B. Marentič Požarnik, Profesionalizacija izobraževanja učiteljev - nujna predpostavka uspešne prenove, Vzgoja in izobraževanje 31/4 (2000), 4-11.

${ }^{114}$ Prim. B. Marentič Požarnik, Kako pomembna so pojmovanja znanja, učenja in poučevanja za uspeh kurikularne prenove (drugi del), Sodobna pedagogika 49/4 (1988), 360-370.
} 
de in oblike, vprašanja, ki jih bo postavljal in za način preverjanja. Hkrati s tem pa opozarja, da so pojmovanja subjektivno obarvana, ne povsem zavestni in med seboj skladni konstrukti, ki jih posameznik oblikuje na osnovi nakopičenja izkušenj.

Duffy ${ }^{115}$ takšnim prepričanjem pravi mentalni modeli in opozarja, da se ti običajno upirajo spremembam, čas sprememb pa to večkrat zahteva. Ljudje ne marajo spreminjati tega, kar mislijo, da že vedo. Ko sprejmejo novo informacijo, jo najprej preverjajo v odvisnosti od tega, ali je ta v skladu s tistim, kar že vedo. Problem nastane, če nove informacije ne morejo povezati na obstoječ mentalni model oziroma prepričanje. V tem primeru bo človek zgradil novo prepričanje ali pa zavrnil informacijo kot nepomembno ali napačno. Toda tudi v primeru, ko novo informacijo povežejo $s$ tistim, kar že vedo, jo pojmujejo po svoje. Prav obstoječi mentalni modeli so lahko največja ovira spremembam na področju vzgoje in izobraževanja. To, kar vzgojitelji mislijo, da vedo in da delajo, jih lahko ovira pri tem, da bi videli tisto, kar se morajo naučiti in spremeniti. Njihovi mentalni modeli morajo postati gibljivi. Takšni mentalni modeli pa delujejo tudi na kolektivnem nivoju (npr. na nivoju celega vrtca). Za spreminjanje mentalnih modelov je po mnenju Duffyjeve pomembno predvsem, da postanejo vidni, oziroma da so v ospredju razgovorov in profesionalnega razvoja. Raziskave vse bolj poudarjajo pomen neprestane profesionalne rasti vzgojiteljev, stalnega dograjevanja znanj in spretnosti v skladu s spremembami v družbi ter znanstvenimi spoznanji na področju pedagoških znanosti. V zadnjih tridesetih letih se je nakopičilo veliko novega znanja o tem, kako lahko razvijemo učinkovit sistem profesionalnega razvoja vzgojiteljev. Danielsonova in McGreal menita, ${ }^{116}$ da so najbolj učinkoviti programi profesionalnega razvoja tisti, ki:

- stimulirajo in podpirajo iniciative, ki nastajajo v praksi;

- temeljijo na trenutno doseženi stopnji spoznanj o učenju in razvoju, zato naj bi dober strokovni razvoj modeliral principe konstruktivistično pojmovanega učenja in poučevanja;

- nudijo intelektualno, socialno in emocionalno zaposlitev z idejami, materiali in ljudmi (predvsem kolegi);

- kažejo in udejanjajo spoštovanje do vzgojiteljev kot strokovnjakov in odraslih ter otrok;

\footnotetext{
${ }^{115}$ Francis M. Duffy, I think before I am resistant to change, The Journal of the National Staff Development Council 24/1 (2003), 30-37.

${ }^{116}$ Charlotte Danielson, Thomas L. McGreal, Teacher Evaluation to Enhance Professional Practice. Association for Supervision and Curriculum Development, Alexandria 2000.
} 
- nudijo dovolj časa in neprekinjeno podporo vzgojiteljem, da osvojijo nove vsebine in strategije in jih integrirajo v svojo prakso.

Okolje za takšno učenje $\mathrm{v}$ praksi mora biti načrtovano in spoštovano. Elementi tega okolja so:

- Sodelovalna kultura strokovnega usposabljanja.

- V tem procesu ni ekspertov, vsi se učijo drug od drugega.

- Vsi pričakujejo, da so dejavnosti, ki jih počnejo, strokovno koristne.

- Vloga vodje je usmerjena $k$ temu, da je učenje vzgojiteljev namenjeno izboljšanju učenja otrok in njihovega počutja, v čemer se verjetno najbolj kažejo sodobni, na otroka osredotočeni pristopi.

- Posebna skrb se nudi novincem, ki potrebujejo še več podpore in pomoči. To se najlažje uresniči s sistemom mentorstva, vendar morajo novinci to pomoč čutiti, če pa sistem mentorstva ni vzpostavljen, so novi vzgojitelji izpostavljeni stresu, nezainteresiranosti za profesionalni razvoj, cinizmu ipd. Mladi vzgojitelji naj ne bi imeli občutka, da so sami v svojem profesionalnem življenju.

- Ko vzgojitelj doseže stalno delovno mesto, postane polni člani strokovne skupnosti. Na ta način mu prenesemo sporočilo, da ne dvomimo v njegovo kompetentnost (zmožnosti opravljati poklic vzgojitelja) in sposobnost za stalen profesionalni razvoj, to pa hkrati nosi s sabo spoznanje, da njegova služba ni pod vprašajem.

- Pripravljenost za strokovno tveganje je mogoče doseči le, če vzgojiteljevo delovno mesto ni ogroženo. Naši mladi vzgojitelji so pri tem žal obremenjeni s statusom zaposlitve za »določen čas«.

\section{Evalvacija vzgojitelja}

Evalvacijski sistemi za ocenjevanje pedagoškega osebja so se v svetu razvili v sedemdesetih letih in odražajo prepričanje o tem, kako so tedaj gledali na poučevanje in učenje ter pedagoški proces. Tradicionalni pristopi $\mathrm{k}$ evalvaciji vzgojiteljev niso več primerni v trenutku, ko so rezultati, ki jih pričakujemo, na nivoju bolj kompleksne narave učenja (kompleksno učenje, reševanje problemov, uporaba naučenega ipd.).

Za tradicionalni sistem evalvacije vzgojiteljev je značilna hierarhična enostranska komunikacija. Večina teh evalvacij je potekala od zgoraj navzdol, edini dokaz vzgojiteljeve kakovosti je bilo to, kar je ocenjevalec zbral med opazovanjem. Vzgojiteljeva vloga je bila popolnoma pasivna tudi $\mathrm{v}$ primeru, če je evalvacijo opravilo vodstvo institucije, v kateri je bila dobra 
klima. Sistem ni delal razlik med novimi, mladimi vzgojitelji in izkušenimi praktiki. Omejena je bila tudi strokovnost ocenjevalcev, ki so opravljali nadzor, supervizijo ali ocenjevanje. Nemalokrat je imel vzgojitelj veliko več znanja in izkušenj o svoji disciplini, sodobnih pedagoških pristopih in razvojnih značilnostih kot pa tisti, ki ga je ocenjeval. Omejeno strokovno znanje evalvatorjev, malo medsebojnega razumevanja o tem, kaj je dobra pedagoška praksa, nizek nivo zaupanja med vzgojiteljem in ocenjevalcem je oblikovalo kulturo pasivnosti. Takšna klima pa ne daje strokovnih izzivov in ne spodbuja strokovnega napredka. Pogosto je bilo okolje, ki je obkrožalo vzgojitelja, zastrupljeno z nezaupanjem med vzgojitelji ter med vzgojitelji in vodstvom oziroma tistim, ki je izvajal ocenjevanje. Na ta način je evalvacijski sistem pridobil prizvok kaznovalnega postopka. Tradicionalni sistemi ocenjevanja kakovosti vzgojitelja so pretežno temeljili na sodbah ocenjevalca (notranjega ali zunanjega), ne pa na opazovanju in dokazljivih dejstvih. Prav tako ni dovoljeval vzgojitelju, da predstavi svojo interpretacijo dogodka ter omogočal odkrit strokovni razgovor o poučevanju in učenju.

Bobbett in Ellet ${ }^{117}$ poudarjata, da tradicionalni sistem evalvacije vzgojiteljev ni izkoristil možnosti za to, da bi se v tem procesu vrtec in vzgojitelji česa naučili, spremenili in tako vplivali na učenje in razvoj otrok. Avtorja ob tem razmišljata tudi o razlikah med ocenjevanjem $\mathrm{v}$ pomenu spremljanja ter ocenjevanjem v smislu vrednotenja vzgojiteljevega dela. Pri tem spremljanje pojmujeta kot nepretrgan proces, v katerem zbrani podatki predstavljajo »nepretrgan sklop termometrov«, ki jih uporabljamo, da bi naredili sklepe o kakovosti učenja in skrbi za otroka v oddelku. O vrednotenju pa govorita v primeru, ko se zbrane podatke primerja s standardi, da bi prišli do končne, sumativne odločitve, npr. v zvezi s certifikacijo.

Bobbett in Ellet ${ }^{118}$ tudi opozarjata, da je v sodobnih postopkih evalvacije potrebno usmeriti našo pozornost predvsem na aktivni proces učenja otrok. Opazovanje naj bi bilo usmerjeno na učenje in poučevanje, na interakcijo med vzgojiteljem in otrokom in interakcijo med otroki. Gre torej za preobrat razmišljanja o kakovosti vzgojitelja, ki se kaže v usmerjanju pozornosti na to, kaj vzgojitelj dela, da bi omogočil učenje otrok, kako se ti učijo, kako razumejo in spreminjajo življenje v oddelku. Opazovanje in ocenjevanje naj bi bilo torej predvsem usmerjeno na to, kako kakovostni so pogoji za proces učenja.

\footnotetext{
${ }^{117}$ Jacquline J. Bobbett, Chad D. Ellet, Equity and Excellence in America's Schools: The Case for Learning Equity and Proposed Models for Analysing State Wide Education Reform Initiatives (Paper presented at the annual meeting of the AERA), Chicago 1997.

${ }^{118}$ J. J. Bobbett, C. D. Ellet, n. d.
} 


\section{Zakaj evalvirati vzgojitelja}

$\mathrm{Ob}$ razvoju in raziskovanju problema ocenjevanja vzgojiteljev v zadnjih tridesetih letih lahko izluščimo naslednje ugotovitve:

- Tako vzgojitelji kot vodstvo predšolskih institucij se zavedajo pomena in potrebe po evalvaciji; dvomi so prisotni le glede načinov, kako se le-ta izvaja. Prav tako dvomijo v učinek, ki ga ima evalvacija na vzgojitelja, njegov oddelek in otroke.

- Evalvacijski sistemi, ki so zgrajeni tako, da podpirajo in spodbujajo vzgojiteljev profesionalni razvoj in temeljijo na formativnih evalvacijskih tehnikah, pripeljejo do višjega zadovoljstva vzgojiteljev, boljše refleksije in višje strokovne odgovornosti vzgojitelja.

$S$ pojavom ugotavljanja, zagotavljanja in spreminjanja kakovosti na nivoju predšolskih institucij se veča tudi interes in pomen evalvacije vzgojiteljev kot enega od osnovnih vidikov napredka in spreminjanja vrtca. ${ }^{119} \mathrm{Ta}$ interes prihaja iz spoznanja, da bistvenih sprememb ne moremo doseči brez spreminjanja osrednje vloge vzgojitelja v tem procesu. Avtor poudarja, da ne glede na to, kako dobro je določen program oblikovan, je tak program učinkovit le, če ga podpirajo ljudje, ki ga uvajajo. $V$ tem procesu pa nam lahko veliko pomaga poštena in učinkovita evalvacija, ki temelji na opravljenem delu in je hkrati namenjena profesionalnemu napredku vzgojitelja in institucije. Avtor tudi meni, da je primeren sistem evalvacije vzgojitelja vitalna značilnost vsake uspešne šolske reforme. ${ }^{120}$ Konceptualno usklajen in primerno implementiran sistem evalvacije vzgojiteljev je vitalnega pomena za uspeh reforme.

Obstajata dva osnovna namena evalvacije vzgojiteljev. Prvi je v napredku kakovosti njegovega dela in v strokovni odgovornosti (ang. accountability), ki se ji v zadnjem času namenja vse več strokovne pozornosti. Ta odraža potrebo po določitvi kompetenc vzgojitelja, ki bodo zagotavljale, da je delo, ki ga opravlja, tudi učinkovito. V tem primeru gre za evalvacijo, ki je po svoji naravi sumativna. Ta del evalvacije je usmerjen na rezultat in naj bi prispeval k uresničevanju osebnih ciljev vzgojitelja in k poslanstvu institucije oziroma programa. Drugi del evalvacije je usmerjen na proces in napredek, tako da prispeva k osebnemu in profesionalnemu razvoju posameznika in razvoju znotraj vrtca. $V$ tem primeru gre za formativno evalvacijo, ki je namenjena povečanju vzgojiteljevih znanj in spretnosti, kot so npr.

${ }^{119}$ James H. Stronge, Preface, v: J. H. Stronge (ur.), Evaluating Teaching: A guide to current thinking and best practice, 1997.

${ }^{120}$ J. H. Stronge, n. d. 
konstruktivne povratne informacije, prepoznavanje dobre prakse, usmerjenost na strokovne razgovore ipd. $V$ tem procesu gre za profesionalni razvoj in rast posameznega vzgojitelja, ki v končni fazi prispevata h kakovosti dela. Obe dimenziji sta v sistemu evalvacije vzgojitelja nujni, če hočemo, da bo evalvacija služila tako posamezniku kot instituciji. Oba temeljna namena evalvacije pa je potrebno racionalno povezati.

Različni posamezniki in skupine dajejo tem namenom različen pomen. Politiki po naravi svoje vloge cenijo sumativno evalvacijo, v kateri je poudarjeno zagotavljanje kakovosti in odgovornost vrtca kot javne institucije in tako zagovarjajo interes in zahtevo javnosti, da sta učenje in skrb za otroke kakovostna. Na drugi strani pa vzgojitelji prvenstveno zagovarjajo tezo, da mora evalvacija vzgojiteljev predvsem prispevati $\mathrm{k}$ njihovemu profesionalnemu razvoju, ki bo prispeval $\mathrm{k}$ boljšemu učenju in skrbi za otroke.

Pri tem se ne moremo izogniti vprašanju, ali gre za nezdružljivost obeh namenov evalvacije. Nekateri menijo, da sta vlogi ocenjevalca in tistega, ki je ocenjevan, strogo ločeni, saj gre za ločenost zahtev in odgovornosti vsakega od njiju, ki ju zahteva hierarhija. Drugi pa se bolj zavzemajo za mehkejše odnose, več zaupanja med vzgojiteljem in tistim, ki ocenjuje. V interakciji, ki je usmerjena na profesionalni razvoj in učenje, je vloga ocenjevalca bolj usmerjena na spodbujanje in usmerjanje ter mentorstvo, v katerem vzgojitelj ob aktivnem sodelovanju in participaciji nima strahu in lahko pričakuje pomoč. Ali lahko v procesu evalvacije vzgojiteljev ta nasprotja presežemo? Danielsonova in $\mathrm{McGreal}^{121}$ menita, da je stopnja nezdružljivosti oziroma združljivosti teh dveh osnovnih namenov evalvacije odvisna predvsem od strukture in procedur, ki jih uporabljamo v procesu evalvacije.

\section{Osnove za oblikovanje evalvacije vzgojitelja}

$\mathrm{Na}$ evalvacijo vzgojitelja moramo seveda najprej pogledati z vidika tega, kar smo se doslej v tem procesu že naučili. Na osnovi literature ${ }^{122}$ lahko povzamemo nekaj najpomembnejših vodil:

\footnotetext{
${ }^{121}$ C. Danielson, T. L. McGreal, n. d.

${ }^{122}$ C. Danielson, T. L. McGreal, n. d.; J. H. Stronge, n. d.; Patricia H. Wheeler, Michael Scriven, Building the Foundations: Teachers Role and responsibilities, v: J. H. Stronge (ur.), Evaluating Teaching: A guide to current thinking and best practice, 1997; Chad D. Ellet, Classroom based Assessments of Teaching and learning, v: J. H. Stronge (ur.), n. d.; Roland S. Barth, Improving Schools from Within, Teachers, parents, and principals can make the difference, San Francisco 2000; M. Fullan, The new meaning of educational change, New York 1991; M. Fullan, Turning systemic thinking on its head, Phi Delta Kappan 77 (1996), 420-423.
} 
- Proces razvoja institucije na področju vzgoje in izobraževanja je mnogo boljši, če so vsi deli, ki sestavljajo napore za razvoj institucije, med seboj povezani. Sistem evalvacije vzgojiteljev naj ne bi bil ločen od ostalih iniciativ vrtca. Evalvacijski sitem naj bi bil povezan s tistim, kar skuša institucija doseči na nivoju učenja in skrbi za otroke. Ko Fullan razmišlja o neuspehih šolskih reform, meni, da je sistematični neuspeh šolskih reform mogoče pripisati razdrobljenosti, ki se pojavlja ob nepovezanosti oziroma učinkih, ki se križajo. ${ }^{123}$ Tako imamo lahko na eni strani veliko pripravljenost za spremembe na nivoju institucije, ni je pa na nivoju posameznika, kar pripelje do križanja interesov in zmanjšanja učinkov. Uravnovešanje potreb posameznika s pričakovanji institucije je nujno za ustvarjanje produktivnega delovnega okolja. V tem procesu lahko vzgojiteljeva evalvacija postane gonilna sila, $s$ katero zadovoljujemo in ocenjujemo uspeh posameznega vzgojitelja (osebno rast in napredek kakovosti njegovega dela) in vrtca. Fullan meni, da lahko evalvacijo vzgojitelja pojmujemo kot vitalni del napredka in razvoja vrtca: napredka v smeri kakovosti dela posameznega vzgojitelja ter drugih zaposlenih, napredka v programu in dejavnostih za otroke, starše in skupnost in napredka $v$ sposobnosti vrtca, da izpolni svoje poslanstvo. Združevanje individualnega in institucionalnega napredka ni lahko, vendar ima jasno sporočilo - enega brez drugega ne moremo doseči. ${ }^{124}$

- Evalvacija in profesionalni razvoj sta neprekinjena procesa. Sistema evalvacije in profesionalnega razvoja nista statični kategoriji, ampak gre za neprekinjen proces. Načrti profesionalnega razvoja, ki nastajajo preko sistema evalvacije, morajo biti usmerjeni nekaj let vnaprej. Kompleksne aktivnosti, ki naj bi jih osebje izvršilo, zahtevajo svoj čas za usposabljanje, za uvajanje in za refleksijo. Postati morajo del vsakodnevne rutine in življenja v instituciji.

- Evalvacijski sitem naj poudarja tudi rezultate (napredek v razvoju otrok), vendar rezultati otrok nikakor ne smejo biti edino merilo kakovosti vzgojitelja.

- Evalvacijski proces mora hkrati zagotoviti kakovost in spodbujati profesionalni razvoj.

- Poskrbeti je potrebno za sredstva, čas in ustrezno podporo vzgojitelju tudi v procesu profesionalnega razvoja po evalvaciji.

${ }^{123}$ M. Fullan, n. d. (1996).

${ }^{124}$ M. Fullan, n. d. (1991). 
Pri oblikovanju evalvacije vzgojiteljev si moramo najprej odgovoriti na dve vprašanji:

1) Kaj je dobro učenje in skrb za otroke oziroma pod kakšnimi pogoji se otroci dobro počutijo in učijo? $\mathrm{V}$ zadnjih tridesetih letih so se vzgojitelji veliko naučili o tem. Nekateri vzgojitelji so sicer še vedno nagnjeni $\mathrm{k}$ temu, da se pretvarjajo, da ne vedo tistega, kar vemo novega o učenju in dobrem počutju otrok, saj je lažje, da se držijo tistega, kar so delali doslej in $\mathrm{v}$ kar so bili prepričani, kot pa da gredo skozi boleč proces spreminjanja obstoječega razmišljanja in delovanja. Danielsonova in McGreal menita, ${ }^{125}$ da se vsaka učinkovita evalvacija in program profesionalnega razvoja začneta $\mathrm{z}$ bogatimi standardi, ki odražajo to, kar trenutno vemo o procesu učenja in razvoja na osnovi raziskovalnih dokazov.

2) Drugo vprašanje, na katerega moramo odgovoriti, pa je vprašanje, kakšni postopki in procesi bodo najbolj ustrezali tistemu, kar želimo doseči z našim sistemom. Ob tem se srečamo z nujnostjo preoblikovanja tradicionalne evalvacije vzgojiteljev, ki mora zajeti preoblikovanje rutine opazovanja $\mathrm{v}$ oddelku in načina sledenja. Večina strokovnjakov se strinja, da obstaja prednost biti opazovan in kasneje v poglobljeni diskusiji in refleksiji poglobiti in razložiti, kaj in zakaj se je nekaj dogodilo. V tem procesu pa je potrebno vzgojitelju omogočiti, da pove svoje mnenje, da se vključi v strokovne skupine, ki bodo znale oblikovati vodila, akcijsko raziskovati, oblikovati strokovni portfolio, pisati načrt za samousposabljanje ipd. Enotnega pristopa za vse vzgojitelje pri tem ni mogoče doseči zaradi izrazitih razlik $\mathrm{v}$ načinih in stilih učenja pa tudi zaradi razlik $\mathrm{v}$ doseženem profesionalnem razvoju. Njihovim potrebam po strokovni rasti se bomo najlažje približali z upoštevanjem različnosti.

\section{Značlnosti sistema evalvacije vzgojitelja}

Evalvacije vzgojitelja ne gre enačiti z opazovanjem v oddelku. Čeprav je seveda primerno opazovanje v oddelku pomemben element $v$ strukturi procesa evalvacije in tudi strokovnih razgovorov, to še ni cel sistem evalvacije. Učinkovit sistem evalvacije vzgojiteljev je bolj kompleksen in vsebuje vsaj naslednje pomembne elemente:

1) Jasno definirana področja o tem, kaj ocenjujemo (odgovor na vprašanje: Kaj?) in odločitev, ki zadeva nivo za zaželeno kakovost (odgovor na vprašanje: Kaj in kako dobro je zadosti dobro?). Evalvacija naj temelji na standardih, ki so utemeljeni na raziskavah. Standardi na nek način povzemajo ugotovitve različnih raziskav in dokumentov o tem, kako naj bi pote-

${ }^{125}$ C. Danielson, T. L. McGreal, n. d. 
kal proces učenja, $\mathrm{v}$ katerem lahko vsak otrok oblikuje in doseže želene kompetence. Kot primer lahko navedemo sedem ključnih področij, ki jih je identificirala ISSA ${ }^{126}$ kot osnovo, okrog katerih so določeni standardi. Ta področja so: interakcija, družina in skupnost, inkluzija, različnost in demokratične vrednote, sledenje in načrtovanje, strategije poučevanja, učno okolje in profesionalni razvoj. Za vsako od naštetih področij je definiranih od tri do pet standardov, skupaj pa dvajset standardov, ki so nastali na osnovi znanstvenih ugotovitev oziroma rezultatov raziskav, Konvencije o otrokovih pravicah, Lizbonske deklaracije, ki določa kompetence otrok ter skupnih evropskih principov za kompetence vzgojiteljev/učiteljev ter smernic za izboljšanje usposabljanja vzgojiteljev/učiteljev.

Evalvacija naj bi nudila vzgojiteljem možnosti, da so na različni stopnji strokovnega razvoja vključeni v različne aktivnosti. Evalvacija naj ne bo usmerjena le na končni rezultat, ampak naj bo tudi formativna in naj spodbuja profesionalno učenje in napredovanje. Zagotavljanje kakovosti temelji na jasno zastavljenih standardih (npr. vzgojitelj ustvarja različne možnosti za sodelovalno učenje, prilagaja učne pristope različnim stilom učenja, izbira aktivnosti, ki zahtevajo smiselno in aktivno učenje ipd), ki jih lahko dosežemo v okolju, ki spodbuja profesionalno učenje in razvoj. Pri evalvaciji vzgojiteljev in poučevanja torej ne gre za dilemo, ali je ta potrebna ali ne, ampak za dilemo, kako jo izvajamo na operativnem nivoju v skladu z zahtevami sodobnih spoznanj o profesionalnem razvoju.

2) Standardi kakovosti vzgojitelja naj bi torej na znanstveni osnovi in nakopičenih spoznanjih o dobri praksi definirali vlogo vzgojitelja oziroma to, kar naj bi ta počel, da bi lahko trdili, da je njegovo delo kvalitetno. $\mathrm{Na}$ ta način standardi definirajo tudi cilje vzgojiteljevega profesionalnega razvoja. Standardi naj bi vključevali vse pomembne vidike poučevanja in se ne smejo omejevati le na določene dele vzgojiteljevega dela. Potrebno pa je določiti tudi njihovo relativno pomembnost, torej odgovoriti je potrebno na vprašanje, ali so vsi enako pomembni, upoštevati pa je potrebno tudi nivoje kakovosti, oziroma, kako dobro je dovolj dobro in kako dobro je zelo dobro. Definiranje vzorne prakse z nivoji uresničevanja lahko zelo pospeši profesionalni razvoj vzgojitelja.

3) Tehnike in postopki za sledenje in ocenjevanje vzgojiteljevega dela oziroma njegove pedagogike (odgovor na vprašanje: Kako?). Ko identificiramo določene kriterije, ki naj bi prispevali k dobri kakovosti, moramo zagotoviti tudi to, da bodo lahko vzgojitelji te standarde demonstrirali pri

${ }^{126}$ International Step by Step Association, Competent Teaching for 21st Century, Amsterdam, Budapest 2009. 
svojem delu. Vseh dejavnosti vzgojitelja ne moremo neposredno opazovati v oddelku, ker jih tam ni, ali pa so skrite, zato jih je potrebno evalvirati z drugačnimi tehnikami in postopki. Postopki naj omogočajo ocenjevalcu, da naredi razumno presojo glede kakovosti poučevanja. Celoten sistem naj zagotovi vzgojitelju pomoč pri evalvaciji kakovosti in profesionalnemu razvoju, če jo ta potrebuje. $V$ tem okviru morajo postopki in tehnike odgovoriti tudi na vrsto vprašanj, ki so povezana s časovnim razporedom evalvacije, splošnimi navodili, diferenciacijo, če je ta prisotna, z osebno vpletenostjo vzgojitelja ipd.

4) Usposobljene ocenjevalce, ki znajo dosledno presojati o delu na osnovi dokazov.

$S$ stališča vzgojiteljev naj bi bilo vseeno, kdo jih evalvira. Rezultat naj bi bil vedno enak. Seveda se povsem idealnim razmeram na tem področju ne moremo približati, ker je pri evalvaciji vedno vsaj delno prisoten tudi subjektivni faktor ocenjevalca. Zelo veliko pa lahko k doslednosti $\mathrm{v}$ ocenjevanju in presojanju dosežemo z usposabljanjem ocenjevalcev in vključevanjem ocenjevalcev v postopke za doseganje zanesljivosti. Takšno usposabljanje naj bi usposobilo ocenjevalca za naslednje dejavnosti: - prepoznavanje standardov in kazalcev v praksi in akciji, prepoznavanje reprezentativnih primerov (pozitivnih in negativnih)v praksi;

- interpretiranje dokazov za določene vidike poučevanja v odnosu do ocenjevalnih kriterijev (standardov); pravilna interpretacija je pomemben vidik strokovne presoje o poučevanju;

- oblikovanje presoje o poučevanju, v kateri poveže interpretacijo z opisom nivojev doseganja standarda;

- uspešno reflektivno komuniciranje;

- sporočanje konstruktivnih povratnih informacij;

- uspešno vključevanje vzgojitelja v strokovni dialog;

- sposobnost oblikovanja strokovnih konsenzov z vzgojiteljem, ki je v procesu evalvacije;

- zanesljivost v opazovanju in ocenjevanju.

\section{Kriteriji evalvacije}

Osnova vsakega evalvacijskega sistema so evalvacijski kriteriji ali standardi, na katerih evalvacija temelji. Določitev kriterijev ni isto kot razviti evalvacijski sistem. Evalvacijski kriteriji določajo, kaj je kvalitetno delo vzgojitelja, s tem pa kažejo tudi določene vrednote in filozofijo. Lahko so 
oblikovani na osnovi tega, kar vzgojitelj dela, da bi zagotovil kvalitetno učenje otrok ali na osnovi mer otrokovega učenja. Prvi temeljijo na vložkih, zadnji na učinkih. Prvi imajo daljšo tradicijo pri evalvaciji vzgojitelja, čeprav se dandanes, prav zaradi strokovne odgovornosti vzgojitelja, vse bolj skušajo vključiti v evalvacijo tudi mere učenja pri otrocih. Vendar to še vedno ostaja eno najbolj nedorečenih vprašanj evalvacije vzgojiteljev. Evalvacija, ki temelji na rezultatih učenja, je povezana $z$ ocenjevanjem, testiranjem, zunanjimi vplivi na otroke, ki so še bolj zapleteni. Oba koncepta evalvacije imata tako svoje močne in šibke strani. Razumno pa je oba pristopa na nek način vključiti v dobro uravnovešeno evalvacijo. Primer takšnega koncepta so ISSA pedagoški standardi. ${ }^{127}$ Standardi morajo imeti izdelane kazalce, ki omogočajo podati povratno informacijo in postaviti cilje profesionalnega razvoja. Opisani morajo biti nivoji pojavljanja vsakega kazalca. Obstaja pa še nekaj merskih problemov, kot so npr.:

- Ali so vsi standardi in kazalci enako pomembni?

- Ali so nekateri bolj pomembni kot drugi?

- Ali so nekateri kazalci v določenih pogojih bolj pomembni kot drugi?

- Kako kombinirati dosežene točke? Ali lahko najvišje ocene na enem standardu ali kazalcu nadomestijo najnižje na drugem?

- Postavljanje mer: kako dobro je dovolj dobro?

- Kako postaviti meje med slabim, dobrim in odličnim? Ali so te meje enake za novince in za eksperte?

- Ali mora vzgojitelj doseči določen nivo kakovosti na vsakem standardu oziroma kazalcu ali le na določenem številu njih?

- Ali zahtevati določen nivo kakovosti na vsakem kazalcu ali pa prejeti skupno oceno?

Viri informacij za evalvacijo vzgojitelja

Veljaven sistem evalvacije vzgojitelja lahko oblikujemo le, če določimo evalvacijske kriterije in nato uporabljamo instrumente in postopke za ocenjevanje vzgojitelja po teh kriterijih. Vsak evalvacijski sistem zahteva od vzgojitelja, da le-ta nekaj postori. To, kar vzgojitelji delajo med evalvacijskim procesom, naj bi omogočalo dokazati vse evalvirane kriterije. Z drugimi besedami, vzgojitelji naj bi med evalvacijo delali to, kar z evalvacijo želimo ovrednotiti. Standardi morajo biti zapisani tako, da je mogoče zago-

${ }^{127}$ International step by step association, Step by Step Program and Teacher Standards for Preschool and Primary Grades, New York, Budapest, Amsterdam 2003; International Step by Step Association, Competent Teaching for 21st Century, Amsterdam, Budapest 2009. 
toviti zanesljivost. $\mathrm{V}$ ta namen potrebujemo tudi kazalce, vendar tudi vseh kazalcev ne moremo opazovati v oddelku in zahtevajo drugo dokumentacijo. Zaradi vseh teh problemov je zelo pomembno načrtovati postopke za zbiranje dokazov, vendar tako, da ti dokazi vzgojitelja dodatno ne obremenjujejo, ampak postanejo hkrati sredstvo za ugotavljanje njegove kakovosti ter način, s katerim se profesionalno razvija.

Tudi v zbiranju in odločanju o dokazih v evalvacijskem postopku najdemo osnovne teoretske razlike med tradicionalnim in sodobnim pojmovanjem evalvacije vzgojiteljev. V tradicionalni evalvaciji vzgojitelja bo ocenjevalec zbral vse dokaze o vzgojiteljevih spretnostih poučevanja med opazovanjem v oddelku. Ocenjevalec opazuje, nato pa zapiše poročilo o tem, kaj je videl v oddelku, se sreča z vzgojiteljem in mu da povratno informacijo. V tem procesu je vzgojitelj izrazito pasiven, opazovalec vodi opazovanje, piše in zaključuje na osnovi evalvacijskih kriterijev, ki jih včasih vzgojitelj niti dobro ne pozna, in poda povratno informacijo.

Sodobna spoznanja, ${ }^{128}$ predvsem pa izkušnje, do katerih so prišli na osnovi sodelovanja v evalvacijskih procesih, kažejo, da je profesionalni razvoj na mnogo višjem nivoju, če je vzgojitelj aktivno vključen in igra aktivnejšo vlogo v tem procesu. Vzgojitelj na primer vodi samoocenjevanje, zbira dokumentacijo o svojem delu, opiše in razloži svojo prakso opazovalcu, razpravlja o svojem pojmovanju ipd.

Evalvacijski postopek na nek način odraža vsa tista izhodišča, ki jih odražajo standardi in indikatorji, za katere se zavzemamo. Če je v evalvacijskem sistemu sprejeta ideja vzgojitelja, ki sprejema odločitve, da bi spodbujal učenje otrok, potem je potrebno sprejemanje odločitev vtkati tudi v evalvacijsko proceduro. Če je definicija poučevanja, na katerih temeljijo standardi, celostna, potem je potrebno temu prilagoditi tudi postopke in vire dokazov, ki naj ne temeljijo le na eni vrsti dokazov. V nadaljevanju bomo na kratko opisali najpomembnejše vire, ki jih predlagajo različni avtorji in na katerih lahko temelji sodobna evalvacija vzgojitelja.

\section{A) Opazovanje v oddelku}

Opazovanje v oddelku je najboljši in edini način, ki omogoča zbrati dokaze za nekatere bistvene vidike učenja in poučevanja (interakcije, strukture okolja, kako vzgojitelj vključuje otroke v učenje ipd.). Neposredno opazovanje lahko v nekaterih primerih zamenjajo tudi video posnetki, ki pa nikakor ne morejo nadomestiti neposrednega opazovanja. Opazovanja

${ }^{128}$ C. Danielson, T. L. McGreal, n. d.; T. Vonta, Kazalci kvalitete organizirane predšolske vzgoje (doktorska disertacija), Ljubljana 2003. 
vzgojitelja v oddelku ne smemo enačiti z evalvacijo vzgojitelja. Opazovanje sloni na premisi, da je opazovanje vzgojitelja v akciji najboljša metoda za presojanje vzgojiteljeve učinkovitosti. Obiski v oddelku so pomembni, vendar ne edini način zbiranja podatkov. Če želimo dobiti splošno in vsestransko sliko o tem, kaj se dogaja v oddelku, da bi lahko usmerjali strokovni razvoj, nam opazovanje nudi le en del informacij. Med razlogi za takšno mnenje Frase in Streshly ${ }^{129}$ navajata: dolžina obiska je kratka, evalvatorji se usmerjajo na tisto, kar je za njih pomembno, večina sistemov zapisovanja ni izdelanih, obstaja možnost osebnega odnosa med evalvatorjem in vzgojiteljem, sam obisk vpliva na otroke in vzgojitelja, veliko dejavnosti vzgojitelj opravi zunaj oddelka, opazovanja niso pogosta ... Zlasti v primeru, ko opazovanje opravljajo ravnatelji, se dogaja, da vzgojitelji dojemajo ravnatelje kot nekompetentne evalvatorje dogajanj v oddelku. Obstajajo tudi dokazi, da so ocene, ki nastajajo ob opazovanju ravnateljev v oddelku, nagnjene k napihovanju. ${ }^{130} \mathrm{~V}$ svoji študiji sta ugotovila, da so bile ocene ravnateljev precej napihnjene in niso nudile koristnih informacij za vzgojiteljev profesionalni napredek.

\section{B) STRUKTURIRANA REFLEKSIJA}

Strukturirana refleksija naj bi omogočala vzgojitelju sistematično zbiranje dokazov o svojem delu in strokovnem napredovanju. Udeleženci evalvacijskih procesov poročajo, kako zelo so napredovali prav med pripravljanjem svojih portfoliev. Usmerjen pristop $k$ strukturirani refleksiji na prakso je potreben. Predstavljajo pa ga lahko različne dejavnosti, ki jih prikazujemo v nadaljevanju.

\section{C) DOKUMENTI NAČRTOVANJA (VZGOJITELJEVA PRIPRAVA)}

Načrtovanje je zelo pomembna dejavnost vzgojitelja, vendar se zelo razlikuje od sposobnosti vzgojitelja, da uspešno vodi vzgojno-izobraževalni proces, v katerem otroci pridobivajo izkušnje. Pri načrtovanju razmišljamo torej o tem, kaj naj bi se otroci naučili, o naravi spoznanja, o tem, kakšni so otroci v našem oddelku, njihovih interesih, sposobnostih za učenje, njihovih izkušnjah in o tem, kako bi otroke na njim smiseln način povezali z vsebino. Skoraj v vseh standardih je načrtovanju namenjena posebna pozornost. Veliko teh elementov sicer ne moremo opazovati v oddelku, toda hkrati je potrebno evalvirati tudi vidike, kot so: ali je pristop povezan in skladen z vsebino, ali aktivnosti, ki so načrtovane, res vključijo otroke in

${ }^{129}$ Larry E. Frase, William Streshly, Lack of accuracy, feedback, and commitment in teacher evaluation, Journal of Personnel Evaluation and Education 1 (1994), 47-57.

${ }^{130}$ N.d. 
jih vodijo $k$ razumevanju osnovnih pojmov ipd. Načrtovanje zahteva vrsto zapletenih znanj vzgojitelja, ki pa niso enake tistim, ki jih zahtevata uvajanje in uresničevanje tega načrta. Načrtovanje mora biti usmerjeno z vidika ciljev podpore učenja otrok. Odseva naj nivoje učenja in to, kar otroci že vedo, ter vključuje elemente aktivnega učenja, participacijo otrok v procesu, pa tudi strategije ocenjevanja oziroma spremljanja učenja pri otrocih.

D) RAZGOVORI PO OPAZOVANJU

Razgovor po opazovanju v oddelku ima več namenov. Helmsova navaja naslednje: ${ }^{131}$

- administrativni razlogi, ki se v glavnem nanašajo na dokumentacijo,

- informativni razlogi,

- motivacijski razlogi,

- reševanje problemov,

- razvijanje strategij,

- postavljanje ciljev.

Temu pa zanesljivo velja dodati še možnost za razkrivanje in proučevanje vzgojiteljevih implicitnih teorij. Srečanje med vzgojiteljem in ocenjevalcem se sedaj pojmuje kot del neprekinjenega procesa komunikacije in povratnih informacij, ki so značilni za kvalitetno mentorstvo. ${ }^{132} \mathrm{~S}$ stalnimi izmenjavami informacij vzgojitelj ve, kje so njegove močne strani in kje so šibke, tako da na koncu ni presenečenj. Značilnosti učinkovitih razgovorov pri evalvaciji pa so:

- Dvosmerna komunikacija. Pri tem velja, da bolj ko je vzgojitelj vključen $\mathrm{v}$ ta razgovor, bolj je zadovoljen $\mathrm{z}$ razgovorom in $\mathrm{z}$ ocenjevalcem. ${ }^{133}$ Ocenjevalec na ta način pridobi tudi koristne informacije o vzgojiteljevem delu ter o njegovih potrebah po profesionalnem razvoju. Vzgojitelj na ta način prevzame tudi večjo obvezo nase za sam proces napredovanja.

- Ravnovesje med doseženim in cilji za prihodnost. Večji del časa naj bi posvetili razvijanju ciljev za prihodnji razvoj. Vzgojitelja je potrebno spodbujati, da sam prevzame iniciativo in identificira cilje in načrt, ki je

\footnotetext{
${ }^{131}$ Virginia Helms, Conducting a Successful Evaluation Conference, v: J. H. Stronge (ur.), Evaluating Teaching: A guide to current thinking and best practice, 1997.

${ }^{132}$ Nancy M. Somerick, Strategies for improving employee relations by using performance appraisals more effectively, Public Relations Quarterly 38/3 (1993), 37-39.

${ }^{133}$ Gordon C. Anderson, Jean G. Barnett, Characteristics of effective appraisal interviews, Personal Review 16/4 (1987), 18-25; T. J. Krein, Performance reviews that rate an "A", Personnel 67/5 (1990), 38-41.
} 
zanj smiseln. Na ta način zagotovimo lastništvo nad cilji in vzgojiteljevo pozitivno mnenje o razgovoru.

- Prepoznavanje vzgojiteljevih močnih strani in uspehov vpliva na vzgojiteljevo motiviranost. Bolj ko so ta specifična in neposplošena, večji učinek imajo.

- Identifikacija in analiza problemov, ki vplivajo na vzgojiteljevo delo. Le nekaj izjemnih vzgojiteljev lahko doseže vse cilje. Kjer pa pride do razočaranj, je potrebno spodbuditi vzgojitelja, da identificira in analizira razloge. $\mathrm{Na}$ ta način naj bi razumel kontekst neuspeha in se nato takoj premaknil na nivo iskanja rešitev tega problema. Opazovalec pri tem vzgojitelju pomaga postaviti vprašanja $\mathrm{v}$ smeri iskanja poti, ki bi pomagale rešiti problem, ki ga vzgojitelj zazna. Po drugi strani pa ga lahko povpraša tudi po tem, kaj on sam (opazovalec) lahko naredi, da bi mu pomagal rešiti problem.

- Vzgojiteljevo sprejemanje ciljev za nadaljnje usposabljanje. Ko vzgojitelju dajemo možnost, da sam postavlja cilje svoje strokovne rasti, mu hkrati zagotavljamo najbolj uspešno možnost za nadaljnji razvoj, veliko boljšo, kot pa je splošen razgovor. ${ }^{134}$ Občutek lastništva nad cilji je najbolj pomemben faktor prevzemanja obveznosti do ciljev in tudi vzgojiteljevega mnenja o učinkovitosti evalvacijskega procesa.

V literaturi ${ }^{135}$ najdemo še nekaj zelo konkretnih nasvetov za učinkovite razgovore med vzgojiteljem in ocenjevalcem. Najuspešnejši razgovor je dialog med vzgojiteljem in ocenjevalcem in ne monolog opazovalca. Pri tem se je treba osredotočiti na vprašanja, povezana s kaj, zakaj in kako. Razgovor lahko nudi izjemne možnosti za spoznavanje vzgojiteljevih prepričanj. Prav tako pa v razgovoru vzgojitelj lahko nezavedno prepričanje sooči z novo informacijo in zgradi novo spoznanje oziroma mentalno strukturo, ki mu bo pomagala v njegovi profesionalni rasti. Nenazadnje pa mu bo razmišljanje o tem, kaj dela in kako razmišlja o svojem delu, v dialogu z ocenjevalcem pomagala ozavestiti svoja prepričanja in prakso in jo tudi lažje spreminjati, če bo to potrebno.

\section{E) Strokovni portfolio}

Strokovni portfolio je ena tistih idej, ki je v zadnjem času izjemno popularna, saj je lahko pomemben motor strokovne refleksije vzgojitelja na svojo prakso. Nekaterih evalvacijskih kriterijev ne moremo neposredno opazo-

\footnotetext{
${ }^{134}$ G. C. Anderson, J. G. Barnett, n. d.

${ }_{135}$ Alexander Hamilton Institute, Effective interviews for every situation, New York 1995; Majda Cenčič, Sistemi kakovosti in vzgojno-izobraževalno področje, Sodobna pedagogika 51/4 (2000), $28-42$.
} 
vati, zato je treba premisliti, kaj bi lahko štelo kot dokaz uresničevanja določenega kriterija. Zbiranje izdelkov v osebnem portfoliu nam lahko pomaga doseči ta cilj. Na ta način mora vzgojitelj materiale, ki jih bo dal v portfolio, preučiti in ugotoviti, kateri najbolje dokumentira njegovo delo in ustreza zahtevanemu kriteriju oziroma standardu (npr. komunikacija s starši). $\mathrm{Ob}$ oblikovanju osebnega portfolia vzgojitelj neprestano čuti in prakticira potrebo po refleksiji svojega dela, zaveda se, kaj vse je naredil, in tako se tudi spremeni njegov odnos do svojega dela. Vendar je tudi v tem primeru v odnosu do portfolia potrebno imeti izdelane evalvacijske kriterije.

\section{F) DRUGI DOKAZI}

Med drugimi dokazi, ki jih lahko upoštevamo pri evalvaciji vzgojitelja, je komunikacija s starši in okoljem, vpogled v vzgojiteljevo strokovna dejavnost, projekti institucije ali določenega okolja, v katere se je vključil, primeri izdelkov otrok ipd.

Sistem evalvacije vzgojitelja, ki vključuje perspektivo drugih na vzgojitelja, kot dodatek k neposrednemu opazovanju vzgojitelja v oddelku, se imenuje »sistem 360 stopinj«. Ta sistem temelji na predpostavki, da vzgojiteljeve zmožnosti lahko gledamo z različnih vidikov. Te metode se zelo uporabljajo v poslovnem svetu, lahko pa se prenašajo tudi v pedagoški svet, ko se formalna evalvacija dopolnjuje npr. z opazovanjem kolegov, staršev ali $s$ proučevanjem mnenj otrok. Katzova ${ }^{136}$ omenja pet različnih perspektiv, iz katerih lahko gledamo na kakovost programa in jih lahko prenesemo tudi na področje ocenjevanja kakovosti vzgojitelja:

- od zgoraj navzdol (z vidika ocene zunanjih opazovalcev),

- od spodaj navzgor (z vidika doživljanja otrok),

- od znotraj (z vidika ocene vzgojitelja),

- od zunaj navznoter (z vidika ocene staršev),

- od zunaj (vidik skupnosti).

V primeru evalvacije vzgojiteljev bi temu veljalo dodati še vidik ocenjevanja s strani drugih vzgojiteljev (kolegov) in ga poimenovati od znotraj navznoter.

Otroci, starši in kolegi nam lahko dajo dokaze o vzgojiteljevem delu. Pri načrtovanju takšnega sistema pa je posebno pozornost potrebno nameniti veljavnosti teh informacij. Proučevanje mnenj otrok naj bo primerno staro-

${ }^{136}$ L. G. Katz, Five perspectives on quality in early childhood programs, Urbana, Illinois: ERIC Clearinghouse on Elementary and Early Childhood Education, ERIC Document Reproduction Service No. ED-351-148, 1993. 
sti otrok in naj bo bolj usmerjeno na dogajanja v oddelku kot pa na samega vzgojitelja. Vsebovati mora le vprašanja, na katere otroci lahko odgovarjajo.

Tudi starši so lahko dober vir informacij, vendar ne o podrobnostih pedagoškega procesa (npr. ali so metode, ki jih vzgojitelj uporablja takšne, da otroci lahko razumejo snov). Starši lahko posredujejo vzgojiteljem koristne informacije, ker pa temeljijo na osebnem zaznavanju, jih ne moremo jemati kot docela zanesljiv vir dokazov. Lahko pa jih zelo koristno uporabljamo za formativno povratno informacijo, ki dopolnjuje ostale kazalce vzgojiteljevega dela. Pomembno je, da vzgojitelj ve in zna uporabiti starše kot dodaten vir informacij o tem, kar počne, in da mnenja staršev na neki način redno zbira, dokumentira in analizira ter vnaša v nove dejavnosti.

Vsi ti viri predstavljajo dokaze za evalvacijo, torej nekaj, na čemer lahko temelji evalvacija, vendar nekateri lahko bolj vodijo vzgojitelja $\mathrm{k}$ nadaljnji profesionalni rasti in učenju kot drugi. Če evalvacijski sistem omogoča izbiro med različnimi viri, naj bi vzgojitelj izbral tiste, ki imajo največji vpliv na profesionalni razvoj.

Stronge in Ostrander ${ }^{137}$ se prav tako zavzemata za vključevanje ključnih $\gg$ klientov $\ll$ v proces evalvacije, tj. otrok, staršev in vrstnikov. Raba raznolikih načinov zbiranja podatkov po njunem mnenju lahko izboljša kakovost celotnih podatkov. Pri tem pa so različni viri podatkov še razmeroma neraziskani. Ob tem je seveda potrebno opozoriti tudi na vprašanje zanesljivosti. Abrami in Apollonia ${ }^{138}$ sta se lotila vprašanja zanesljivosti ocen s strani uporabnikov. Menita, da če ocena pravilno odraža uporabnikovo mnenje o kakovosti usluge, je mnenje seveda pomembno in daje veljavno mero zadovoljstva, po drugi strani pa isto mnenje ne bo dalo veljavne mere o učinkovitosti te usluge (npr.: ocene staršev nudijo vzgojitelju veljavno informacijo o tem, kako so starši zadovoljni, ne pa smiselne informacije o kakovosti poučevanja). Veljavnost informacij s strani uporabnikov po njunem mnenju lahko zagotovimo le, če koreliramo sodbe iz različnih virov. Takšno tezo lahko najdemo tudi pri Epsteinovi, ${ }^{139} \mathrm{ki} \mathrm{pravi,} \mathrm{da} \mathrm{zaradi}$ tega, ker ni preprosto predpisanih spretnosti, ki bi odlično ali do popolnosti definirale učinkovito poučevanje, meritve različnih vidikov poučevanja

\footnotetext{
${ }^{137}$ James H. Stronge, Laura P. Ostrander, Client survey in Teacher Evaluation, v: J. H. Stronge (ur.), n. d.

${ }^{138}$ Phillip C. Abrami, S. Apollonia, The dimensionality of ratings and their use in personnel decisions, v: M. Theall, J. Franklin (ur.), Student ratings of instruction: Issues for improving practice, San Francisco 1990, 97-103.

${ }^{139}$ Joyce L. Epstein, A question of merit: Principals and parents evaluation of teachers, Educational Researcher 14/7 (1985), 3-10.
} 
z mnogovrstnimi mnenji in sodbami dajejo najverjetneje najbolj pošteno in zaokroženo evalvacijo vzgojitelja.

\section{Evalvacijskipostopki}

To so tiste metode (torej: Kako?), ki jih vzgojitelj uporablja, da dokumentira, ali demonstrira svoje delo in znanje (Kaj?). »Kaj in kako « morata biti medsebojno povezana. Ob tem ne gre pozabiti, da se tudi odrasli učijo tega, kar delajo, zato postopki neposredno določajo, ali bo evalvacijski sistem imel in nudil možnosti za profesionalno rast ali ne. Vzgojitelji lahko z vključevanjem v aktivnosti evalvacijskega procesa dejansko izboljšajo svojo prakso. Evalvacijske postopke lahko razdelimo na splošne in specifične. Splošni postopki naj bi odgovorili na vprašanja, kako bo vzgojitelj demonstriral svoje sposobnosti, ali bodo postopki enaki za vse vzgojitelje, ne glede na njihov staž, kakšne aktivnosti se bodo v procesu evalvacije izvajale, koliko časa bodo trajale, kakšno bo zaporedje aktivnosti ipd. Posebni postopki pa se nanašajo na način dokumentiranja, na opis postopka zagotavljanja enakih pogojev za vse, navodila za vzgojitelje, možnost izbire pri dokazih za posamezni kriterij ipd.

\section{Oblikovanje procesa}

Evalvacijski proces je dober le, če je sprejet pri tistih, ki ga bodo uporabljali. Za potrebe zagotavljanja enakosti je potrebno oblikovati evalvacijski odbor, ki je sestavljen iz predstavnikov različnih interesnih skupin, vendar morajo vsi imeti določene kakovosti (kot npr.: interes, pripadnost projektu, voljo, da bi sodelovali, odprtost razmišljanja, vodstvene sposobnosti, veščine komuniciranja). Ta odbor bo določal, kateri postopki se bodo uporabljali za formalno evalvacijo (tudi zunanjo) in kateri za formativno. Točno mora biti določen tudi načrt implementacije procesa.

Nujno potrebno je poskrbeti tudi za usposabljanje ocenjevalcev, če želimo zagotoviti doslednost sodb. Ker se vsak proces ocenjevanja začne z zbiranjem podatkov, je zelo pomembno, da ocenjevalci vedo, kateri podatki so pomembni za določen evalvacijski kriterij. Ocenjevalec mora znati iskati vse dokaze za določen kriterij in jih znati interpretirati. Pogosto je mogoče ob enem dokazu narediti več interpretacij, zato je pomembno, da ocenjevalec o teh dokazih razpravlja skupaj z vzgojiteljem in šele nato pride do sodbe. Končno mora ocenjevalec določiti tudi mero na lestvici, ki najbolje predstavlja dokaze, ki jih je zbral, ter interpretacijo. Šele nato lahko pride do splošne skupne ocene. Novi ocenjevalci naj bi imeli tudi možnost urjenja opazovanja in ocenjevanja, preden začnejo s pravo evalvacijo, najbolje v 
paru ali v troje, tako da imajo možnost primerjati svoje ocene. In končno, le ocenjevalci, ki dosežejo zahtevan nivo zanesljivosti v ocenjevanju, lahko opravljajo zunanjo evalvacijo.

Kako sistem evalvacije vzgojiteljev vgraditi v sistem napredka, razvoja vrtca $v$ smeri zviševanja kakovosti

Da bi zgradili visokokakovosten sistem ocenjevanja vzgojitelja, ki bi bil zgrajen na dinamičnem ravnovesju med napredkom vrtca in napredkom posameznika, je potrebno zagotoviti nekaj ključnih značilnosti. Stronge predlaga naslednje: ${ }^{140}$

- Vzajemni, skupni cilji, ki pa morajo biti vredni in pomembni: če cilji niso vredni doseganja, ni zanimivo, kako dobro jih dosegamo. ${ }^{141}$

- Poudarek na sistematičnemu komuniciranju, tako na nivoju vrtca v odnosu do zunanjih interesnih skupin (o ciljih, vlogi evalvacije v odnosu do tega cilja, opisu dela vzgojitelja, standardih), kot tudi na nivoju vzgojitelja nasproti ocenjevalcu. Bolj ko spodbujamo tovrstno komunikacijo na nivoju celotnega vrtca, bolj bo ta komunikacija zaživela tudi na nivoju vzgojitelja in ocenjevalca.

- Ustvarjanje ustrezne klime in zaupanja med vzgojiteljem in ocenjevalcem.

- Tehnična premišljenost o standardih, ki morajo biti primerni (legalno in etično sprejemljivi), koristni (informativni in formativni), izvedljivi (so učinkoviti, sprejemljivi v kontekstu organizacije, relativno lahki za uporabo), natančni (veljavni in zanesljivi).

- Z uporabo različnih virov informacij za popolnejši vpogled v delo vzgojitelja povečamo zanesljivost in objektivnost. Pri tem so najpogostejši viri dokazov: opazovanje, razgovor z vzgojiteljem, podatki o napredku otrok, portfolio, samoevalvacija ... Na ta način si pridobimo veliko bolj realno sliko o tem, kakšno je stanje in tudi boljšo osnovo za načrt izboljšanja.

Vsaka evalvacija, ki naj bi prispevala $\mathrm{k}$ razvoju institucije in vzgojiteljev, naj bi imela tudi načrt za izboljšanje, ki mora biti specifičen do te mere, da tako vrtec kot kolektiv in tudi posameznik v njem vidita pomen. McGrath predlaga, ${ }^{142}$ da naj načrt za izboljšanje kakovosti vzgojitelja vsebuje naslednje informacije:

\footnotetext{
${ }^{140}$ J. H. Stronge, Preface, v: J. H. Stronge (ur.), n. d.

${ }^{141}$ Michael Scriven, The methodology of evaluation, v: C. H. Weiss (ur.), Evaluating action programs: Readings in Social action and education, Boston 1972.

${ }_{142}$ Mary Jo McGarth, Dealing Positively With the Nonproductive Teacher, v: J. H. Stronge (ur.), n. d.
} 
- specifične postopke, kako lahko vzgojitelj izboljša delo,

- katere vire mu bomo omogočili za to, da bo to dosegel,

- katere mere bomo uporabljali za to, da bomo ugotovili, če je posameznik $\mathrm{v}$ tem napredoval,

- kako bomo vedeli, da se je izboljšal in

- kdaj bomo to preverjali.

Tradicionalno je bila evalvacija aktivnost, ki so jo delali na vzgojitelju. Sodobni pristopi pa postavljajo vzgojitelja v veliko bolj strokovno in aktivnejšo vlogo v tem procesu. Ko ima vzgojitelj vse kvalifikacije, ki jih njegov poklic zahteva za opravljanje tega poklica, se predvideva, da je strokovno kompetenten in lahko evalvacijske aktivnosti izkorišča za širjenje in izboljšanje svoje prakse. Vendar je za to potrebno ustvariti takšen model evalvacije, $v$ katerem bo zagotovljena vzgojiteljeva aktivna vloga, ker se le preko nje lahko uresničuje njegov strokovni razvoj. Vzgojitelji se tako kot drugi ljudje $\mathrm{v}$ večini primerov ne upirajo spremembam, ampak se upirajo temu, da jih spreminjajo.

Na koncu zaokrožimo vse povedano z mislijo, da vsaka resna sprememba kakovosti zahteva določeno spremembo na različnih nivojih in pri različnih udeležencih. $\mathrm{V}$ evalvaciji vzgojiteljev lahko vidimo gibalo profesionalnega dela in rasti ter podpiranja procesa učenja, ki je v skladu z zahtevami sodobne družbe pa tudi sodobnih spoznanj o učenju in razvoju. Evalvacija vzgojitelja nudi tudi osnovo za oblikovanje ustreznih mehanizmov in podpornih sistemov za vzgojiteljev profesionalni razvoj kot so mentoriranje, mreženje, kolegialna pomoč ipd. $S$ tem pa postane tudi gibalo reforme šolstva, če bomo reformo pojmovali kot nepretrgan, kontinuiran proces napredovanja $\mathrm{v}$ smeri odličnosti in upoštevanja sodobnih znanstvenih podmen, ki opredeljujejo ali bodo opredeljevale kakovosten proces učenja, poučevanja in skrbi za otroke. In $v$ tem procesu se skladno s spremembami v družbi, novimi cilji ter znanstvenimi podmenami spreminjajo tudi pogledi na to, kaj je kvalitetna praksa in kako jo vzgojitelj uresničuje. Organizirana predšolska vzgoja $v$ teh procesih ni nikakršna izjema.

\section{Značilnosti profesionalnega razvoja}

Vzgojiteljeva profesionalna rast močno vpliva na kakovost izhodnih kazalcev kakovosti, to je na razvoj sposobnosti, samozaupanja, samostojnosti, sodelovalnosti, sposobnosti izbiranja in odločanja otrok ipd. Verjetno noben faktor v vzgojno-izobraževalni instituciji ne vpliva na otroke bolj kot osebna in profesionalna rast vzgojitelja. Jedro profesionalnega razvo- 
ja nekateri avtorji ${ }^{143}$ vidijo v razvoju zmožnosti za opazovanje in analiziranje posledic uporabe različnih učnih pristopov, pojmovanj in materialov za otroke in stalnega prilagajanja svojih dejanj na osnovi sporočil, ki jih dobivamo od otrok in staršev. Hkrati morajo vzgojitelji biti sposobni postaviti svojo implicitno pedagogiko oziroma svoje obnašanje in pojmovanje o tem, kar delajo, kaj se dogaja v njegovem oddelku in zakaj, v odnos $s$ tem, kar počnejo in pojmujejo drugi vzgojitelji v drugih oddelkih, in tudi s tem, kar od njih pričakujejo vodstvo vrtca, lokalna skupnost, država... Razmišljujoče učenje iz prakse, ki je značilno za profesionalce, raziskovanje in soočanje subjektivnih, implicitnih teorij, postaja $\mathrm{v}$ procesu zagotavljanja višje kakovosti na področju vzgoje in izobraževanja vse bolj potrebno in pomembno, ${ }^{144}$ saj zagotavlja proces vseživljenjskega učenja.

Pogosto vzgojitelji danes počnejo v oddelku to, kar počnejo zato, ker so to počeli včeraj, ali ker mislijo, da to drugi od njih pričakujejo, da bodo počeli. ${ }^{145}$ Gre za neke vrste vztrajanje pri starih vzorcih obnašanja. Ta značilnost je še posebej pereča $\mathrm{v}$ procesih spreminjanja oziroma reformiranja na področju vzgoje in izobraževanja, ker na nek način ohranja nespremenjeno stanje prakse. Še zlasti je ta pojav zaskrbljujoč, če se poveže s prepričanjem, da je vrtec prostor, kjer se učijo otroci, odrasli pa jih poučujejo. Ta značilnost je prisotna tudi na nivoju vrtca, čeprav se na tem nivoju povezuje še z romantičnim gledanjem na otroka, ki je še tako majhen in se tako ali tako ne more resno učiti, ampak se samo igra in se ga varuje.

Barth $^{146}$ meni, da lahko vzgojitelje glede na strokovni razvoj razdelimo v tri vrste:

- V prvo skupino sodijo tisti, ki niso sposobni in tudi ne pripravljeni, da bi kritično preučili svojo prakso, pa tudi niso pripravljeni, da bi to storil kdo drug.

- V drugo skupino sodijo vzgojitelji, ki so kar sposobni in pripravljeni za stalno preverjanje in reflektiranje tega, kar počnejo in občasno v svoje delo iz takšne refleksije vnesejo določene spremembe. Za prihodnost načrtujejo na osnovi tega, kako stvari potekajo danes. Toda ti vzgojitelji se ne počutijo dobro, če kdo drug proučuje njihovo prakso. Zadovoljstvo in potrditev svojega dela dobijo od svojih otrok znotraj oddelka, navzoč-

\footnotetext{
${ }^{143}$ Roland S. Barth, Improving Schools from Within. Teachers, parents, and principals can make the difference, San Francisco 2000.

${ }^{144}$ Cizek, povzeto po: B. Marentič Požarnik, Kako pomembna so pojmovanja znanja, učenja in poučevanja za uspeh kurikularne prenove (drugi del), Sodobna pedagogika 49/4 (1988), 247.

${ }_{145}$ R. S. Barth, n. d., 49.

${ }^{146}$ R. S. Barth, n. d.
} 
nost drugih oseb (odraslih) pa ni zaželena. Te doživljajo kot zavoro, oviro in ne kot pomoč.

- Tretja in najmanjša skupina vzgojiteljev je zmožna in pripravljena kritično analizirati svojo prakso in jo tudi »predstaviti« drugim odraslim. Vzgojitelji v tej skupini so zmožni sami poskrbeti za svoj strokovni razvoj in praviloma niso odvisni od zunanjega razvijalca svojega profesionalnega razvoja. Pri njih je tudi kolegialnost največkrat že oblikovana in lahko delijo svoje vedenje. Tako pride do nivoja, ko je vsak vzgojitelj profesionalni razvijalec za vsakega drugega vzgojitelja, s čimer se osamitev vzgojiteljevega dela močno zmanjša.

Pri profesionalnem razvoju se zato pogosto osredotočimo na to, da bi vzgojitelji iz prve skupine postopno napredovali v drugo skupino, vzgojitelji iz druge skupine pa v tretjo skupino. Pri tem pa velja upoštevati, da pri vzgojiteljih v prvi in drugi skupini obstaja določena stopnja strahu in nezaupanja, ki jo prenašajo tudi na druge vzgojitelje in tudi na otroke v svojih oddelkih. Prav to pa je strup, ki zavira razvoj skupnosti učečih.

Načini, s katerimi skušamo vplivati na strokovni razvoj, so zelo različni, vendar pri tem ne gre pozabiti na to, da poleg tega, kako se vzgojitelji odzivajo na svojo prakso, obstaja tudi razlika med njimi glede učnih stilov. To pa pomeni, da je potrebno tudi pri profesionalnem razvoju podpreti pristope, ki temeljijo na individualizaciji. Povedano drugače: ni vsak pristop k profesionalnemu razvoju primeren oziroma ustrezen za vsakega vzgojitelja, tako kot ni vsaka strategija za razvoj vrtca primerna za vsak vrtec. Tudi profesionalni razvoj vzgojiteljev je potrebno individualizirati, čeprav se ta najbolj uspešno uresničuje v pogojih kolektiva (oziroma skupin), kjer je omogočeno učenje od drugih. Profesionalna rast in razvoj vzgojitelja sta odvisna in povezana $\mathrm{z}$ nekaterimi faktorji, ki jih je $\mathrm{v}$ tem procesu učenja potrebno upoštevati. V nadaljevanju ločeno opisujemo nekatere med njimi, čeprav se v praksi največkrat prepletajo.

\section{Refleksija svoje prakse}

Schon ${ }^{147}$ meni, da se ne naučimo veliko iz svojih izkušenj, ampak se največ naučimo predvsem iz svoje refleksije oziroma svojega razmišljanja o naših izkušnjah. »Refleksija je mentalni proces strukturiranja ali restrukturiranja izkušenj, problema, obstoječega znanja ali vpogledov $\ll .{ }^{148}$ Model vzgojitelja kot razmišljujočega praktika se je uveljavil skupaj z decentrali-

\footnotetext{
${ }^{147}$ Donald A. Schon, The reflectivepractitioner - how professionals think in action, New York 1983. ${ }^{148}$ Korthagen, navedno po: B. Marentič Požarnik, Profesionalizacija izobraževanja učiteljev nujna predpostavka uspešne prenove, Vzgoja in izobraževanje 31/4 (2000), 6.
} 
zacijo kontrole vzgojitelja ter reakcijo na pojmovanje, da je vzgojitelj predvsem uporabnik teoretičnega znanja in uresničevanja pobud od zgoraj. ${ }^{149}$ Reflektivnemu razmišljanju pa bi veljalo nameniti mnogo več pozornosti tudi v procesu usposabljanja bodočih vzgojiteljev.

\section{Samoocenjevanje in samousposabljanje}

Vzgojitelji so strokovnjaki, ki so za opravljanje svojega poklica pridobili formalno izobrazbo, kjer bi morali oblikovati tudi osnovne sposobnosti za odčitavanje močnih in šibkih točk delovanja in pojmovanja svoje vloge. Obstaja pa velika verjetnost, da tisti vzgojitelji, ki to vedo, tega ne bodo pokazali, če okolje, v katerem delajo, ni varno in spoštljivo. Če organiziramo varno in spoštljivo okolje, bo večina vzgojiteljev izbrala pravo pot in svoja prizadevanja osredotočila $\mathrm{k}$ profesionalnemu razvoju na tistem področju, kjer imajo največjo potrebo. Načeloma lahko trdimo, da vzgojitelji, ki so vključeni v samoevalvacijo in strokovno usposabljanje, ki so si ju sami izbrali, pri tem disciplinirano vztrajajo veliko bolj, kot pa če to od njih zahtevajo od zunaj. Ko ljudje izberejo svoje probleme, ki naj bi bili rešeni, ko izberejo svoje lastne projekte in cilje, temu namenijo več energije in časa, kot pa če to zanje naredi nekdo od zunaj.

Danielsonova in McGreal predlagata, da naj bi osnovo za selekcijo področij, na katerih bo potekal profesionalni strokovni razvoj, predstavljala samoevalvacija, ki pa naj bi bila dopolnjena z mnenjem ocenjevalca. ${ }^{150} \mathrm{Me}-$ nita namreč, da so le posebej izkušeni vzgojitelji zmožni precej natančno oceniti lastno prakso in tudi potrebe po dodatni profesionalni rasti, novinci pa so pri tem manj izkušeni. Takšno mnenje lahko potrdijo tudi vsi tisti, ki so kdajkoli skušali graditi vsebino profesionalnega usposabljanja oziroma razvoja na osnovi analize potreb med izvajalci. Razen redkih izjem so njihove ideje zelo skope. Zato avtorja predlagata, da naj bi evalvacija za zelo izkušene vzgojitelje temeljila na samoocenjevanju in samousmerjanju strokovnega razvoja, pri neizkušenih vzgojiteljih pa naj bi bila bolj usmerjena. Avtorja hkrati menita, da je potrebno nameniti posebno pozornost tudi primerom, ko menimo, da ni popolnoma verjeti natančnosti oziroma ustreznosti samoevalvacije ali če predvidevamo, da vzgojitelji niso ozaveščeni o vseh vidikih prakse, ki jim je potrebno nameniti pozornost. $\mathrm{V}$ vsakem primeru pa bi naj samoevalvacija predstavljala začetno točko vseh strokovnih razgovorov v zvezi s profesionalno rastjo in razvojem.

\footnotetext{
${ }^{149}$ B. Marentič Požarnik, n. d.

${ }^{150}$ C. Danielson, T. L. McGreal, n. d., 25.
} 
Načeloma velja, da lahko postanejo vzgojitelji zelo točni pri samoocenjevanju. Če pa želimo samoocenjevanje spremeniti v orodje profesionalne rasti, potem je potrebno vzpostaviti sistem dokumentirane refleksije in raziskovanja (npr. vzgojiteljev portfolio). Po mnenju Danielsonove in McGreala ${ }^{151}$ je samoevalvacija nujen sestavni del evalvacijskega postopka in tudi profesionalne rasti, nikakor pa ni edini. Samoevalvacija nudi dober vir informacij. Če so evalvacijski kriteriji dobro opisani z nivoji kakovosti, lahko vzgojitelji ugotovijo svoje močne in šibke strani. Vsekakor pa je ta del spodbuden za vzgojitelja, da preuči svojo prakso in dokaze, ki jih lahko zbere za svojo samoevalvacijo.

Airasian in Gullickson ${ }^{152}$ menita, da tvori bistvo vzgojiteljeve samoevalvacije prepričanje, da vzgojiteljev glavni razlog za to, da je vključen v profesionalni razvoj, prihaja iz njegovih lastnih izkušenj o tem, kaj pomeni biti vzgojitelj, in osebne potrebe po razumevanju, kritiki in spreminjanju svoje prakse. Samoevalvacija je povezana s pojmi, kot so reflektivni praktik, refleksija na prakso, samorazumevanje, akcijsko raziskovanje, analiza prakse ipd. Vsi ti pristopi na nek način spodbujajo vzgojitelja, da ocenjuje in spremlja svojo prakso na tistih področjih, ki jih sam spozna kot potrebne napredka. Potrebo po samoocenjevanju pa lahko izpeljemo iz:

- potrebe vzgojiteljev po profesionalni rasti,

- potrebe po spreminjanju svoje prakse in znanja,

- potrebe po potrjevanju tega, kar vedo in znajo,

- potrebe po tem, da ugotovijo, kako so učinkoviti,

- prepričanja, da so nekateri vzgojitelji sposobni prevzeti odgovornost za večino svojega profesionalnega razvoja.

Avtorja prav tako zaključujeta, da samoevalvacija nudi vzgojitelju pomoč pri preverjanju in izboljšanju lastne prakse. Čeprav je samoevalvacija pomembna in potrebna, je le del neprekinjenega programa vzgojiteljeve evalvacije. Samoevalvacija mu predvsem pomaga, da se ozavesti, reflektira, analizira in naredi odločitve o svoji praksi. Vendar obstaja v večini vrtcev potreba po dodatnih načinih evalvacije, saj vzgojitelji niso odgovorni le sebi, ampak tudi drugim: otrokom, staršem, kolegom, s katerimi delajo, vrtcu, vodstvu vrtca, kjer so zaposleni, in končno svoji stroki, ki ima svoje standarde in pričakovanja. ${ }^{153}$

\footnotetext{
${ }^{151}$ C. Danielson, T. L. McGreal, n. d.

${ }^{152}$ Peter Airasian, Arlen Gullickson, Teacher Self-Evaluation, v: J. H. Stronge (ur.), n. d.

${ }^{153}$ Carol Anne Dwyer, Daniel L. Stufflebeam, Teacher evaluation, V: D. C. Berliner, R. C. Calfee (ur.), Handbook of Educational psychology, New York 1996, 765- 786.
} 
Samoevalvacija vedno odraža specifično kulturo, vrednote, vire, osebnost in kontekst tistega, ki je vpleten. Ena od slabosti samoevalvacije se kaže v tem, da spodbuja takšno samoevalvacijo, ki najbolje ustreza vpletenim vzgojiteljem in ravnateljem. Če pa je proces organiziran tako, da je za vzgojitelja smiseln in skrbno podprt s strani vodstva, lahko samoevalvacija v njihovi praksi izboljša kakovost procesa.

\section{Skupnost učečih}

Za dosedanje opravljanje poklica vzgojitelja je zelo značilna izolacija vzgojitelja pri njegovem delu. Večino svojega dela vzgojitelj opravlja sam ali skupaj s pomočnikom, ki je vse preveč pogosto premalo vključen $\mathrm{v}$ uresničevanje vzgojnega procesa in obremenjen z nego, pospravljanjem, skrbjo za zadovoljevanje potreb otrok pri oblačenju, obuvanju, hranjenju, higienskih in fizioloških opravilih, počitku ipd. Za profesionalno rast pa sta izmenjava izkušenj in pogledov na možne rešitve izjemnega pomena. Sodelovanje ponuja veliko več možnosti za uravnoteženo in popolnejšo interpretacijo prakse. V primeru, ko skupina vzgojiteljev sodeluje pri projektu, s katerim želijo razširiti svoje znanje, oblikujejo skupnost učečih. To je skupina ljudi, ki teži k skupnemu cilju, pri tem pa med njimi ni razlik v statusu; vsi so enakopravni in vsi so vključeni v aktivnosti, s katerimi želijo pospešiti, dvigniti in razviti svoje razumevanje. Toda tudi v tem primeru mora biti okolje varno za tveganje, saj strah v takšni skupnosti nima svojega mesta.

Do oblikovanja takšne skupnosti učečih se vzgojiteljev pa ne pride samo po sebi. Kultura profesionalnega razvoja ne nastane sama od sebe. Zagotovimo jo lahko tako, da zagotovimo čas za srečanja študijskih skupin, finančna sredstva za strokovna srečanja, različna gradiva in materiale, $s$ katerimi vzgojitelji delajo, in z »oblikovanjem skupnosti kritičnih prijateljev«. Ta kultura pa se odraža tudi na drugih področjih: netolerantnost do negativnih komentarjev o otrocih, o družinah, o kolegih, delitvi materialov, timsko delo zamenja izolirano delo vzgojiteljev ipd. Tudi ti postopki naj bi bili sestavni del samoevalvacije vzgojiteljev.

\section{Usposobljeni opazovalci}

Usposobljeni ocenjevalci so naslednji faktor, ki prispeva k profesionalni rasti vzgojitelja. Dober ocenjevalec zna pritegniti vzgojitelja v zelo strokoven dialog in skozi konsenz takšnega dialoga prispeva k skupnemu razumevanju, kaj je dobra praksa. 


\section{Vpliv evalvacije vzgojitelja na njegov profesionalni razvoj}

Definiranje zgledne, vzorne prakse z nivoji uresničevanja lahko pospešuje profesionalni razvoj. Ko vzgojitelji vedo, kaj je dobra praksa in kako se ta kaže v različnih pogojih, so že vključeni v strokovno razpravo in običajno reflektirajo tudi svojo prakso. Od vseh elementov sistema evalvacije vzgojiteljev prav ti postopki najbolj prispevajo $\mathrm{k}$ njihovi strokovni rasti. Ameriški »Nacionalni svet za profesionalne standarde poučevanja « na osnovi izkušenj z vzgojitelji poroča, »da resnično vsak, ki gre skozi proces, tudi tisti, ki niso uspešni, izjavlja, da je postal boljši vzgojitelj zaradi naporov, ki jih je vložil v ta proces « ${ }^{154}$ Tako postane vprašanje oblikovanja sistema evalvacije vzgojiteljev eno od osrednjih vprašanj profesionalnega razvoja. Kaj naj torej od vzgojitelja zahtevamo, da postori, kar je del tega procesa in kar bo doprineslo $\mathrm{k}$ njegovi profesionalni rasti? Če od njega zahtevamo odgovore na vprašanja, ki zahtevajo refleksijo in razmišljanje, ali če zahtevamo, da izbere dela otrok, ki evidentirajo njihove dosežke, potem se bodo vzgojitelji zanesljivo tudi nekaj naučili iz tega procesa. Poleg samoevalvacije, neposrednega opazovanja v oddelku in razgovora $\mathrm{z}$ vzgojiteljem naj bi vzgojitelji priskrbeli tudi konkretne dokaze o tem, da so se otroci nekaj naučili, pa tudi o svojem delu, ki ga izvajajo zunaj oddelka. Če je evalvacijski sistem dobro oblikovan, potem vzgojitelj prevzame $\mathrm{v}$ njem aktivno vlogo in se $\mathrm{v}$ tem procesu uči z lastno participacijo.

\section{Združevanje zagotavljanja kakovosti in profesionalnega razvoja vzgojitelja}

Ostaja nam torej vprašanje, kakšne značilnosti naj bi imel sistem evalviranja vzgojiteljev, da bi zadovoljil po eni strani potrebe po zagotavljanju kakovosti in po drugi strani njihov profesionalni razvoj. Osnovni obris takšnega sistema bi moral imeti tri značilnosti: diferenciacijo, kulturo strokovnega učenja in skrbno načrtovane evalvacijske postopke. Evalvacijskim postopkom in kulturi učenja smo že namenili pozornost v prejšnjih poglavjih. Na tem mestu bomo nekaj pozornosti namenili le diferenciaciji.

\section{Diferenciacija}

Profesionalna kariera vzgojitelja v času aktivnega dela v življenju ima različne cikle (novinec, začetnik, usposobljeni vzgojitelj, uspešni vzgojitelj, ekspert). Zato naj bi bili tudi različni postopki evalvacije vzgojitelja v različnih ciklih njihove strokovne kariere. Poklic vzgojitelja je kompleksen, kajti spretnosti in znanja, ki jih potrebujemo za uresničevanje tega poklica, terjajo določen čas. Ko pa vzgojitelj osvoji določen nivo profesionalno-

${ }^{154}$ Navedeno po: C. Danielson, T. L. McGreal, n. d., 27. 
sti pri svojem delu, njegovo učenje postane drugačno od tistega, ki ga je bil navajen pred tem in je lahko bolj samousmerjeno. In če vzgojitelj zdrsne v svoje ustaljeno obnašanje in pojmovanje ali če njegov način dela zdrsne pod določen nivo, bo lahko napredoval le v primeru, če bo imel podporo bolj razvitega kolege ali nekoga, ki mu takšno podporo lahko nudi. Takšna opredelitev njegovega učenja izhaja iz teorije nudenja zidarskega odra (scaffolding), ki jo je podal Vigotski. V tem primeru ga bolj razvit kolega lahko potegne navzgor oziroma mu pomaga priti na višji nivo. To pa pomeni, da postopki, ki jih načrtujemo, ne smejo biti enaki za vse vzgojitelje, ampak se morajo prilagajati različnim nivojem oziroma stopnjam v doseženi profesionalni karieri vsakega posameznika.

Najnovejši pristopi k evalvaciji in profesionalnemu razvoju zahtevajo, da vzgojitelj sodeluje v samoevalvaciji, postavi cilje svojega profesionalnega razvoja, sodeluje v študijskih skupinah ali v strokovnih združenjih s kolegi in prispeva k skupnemu interesu. Dodatno se poleg opazovanja v oddelku zahteva, da izbere dokaze svoje strokovnosti v obliki zapisov, načrtovanja, primerih del otrok s komentarjem in drugimi dokazi o svojem delu (komunikacija s starši, šolo ipd.). Izbor tega materiala terja veliko mero refleksije o svoji praksi. Zagotavljanje kakovosti in profesionalen razvoj se dopolnjujeta prav s kombinacijo različnih aktivnosti.

Danielsonova in $\mathrm{McGreal}^{155}$ vidita v procesu evalvacije vzgojitelja priložnost za spajanje dveh procesov, tj. zagotavljanja kakovosti in profesionalnega razvoja, kar prikazujeta tudi shematično.

\begin{tabular}{|l|l|l|}
\hline \multicolumn{1}{|c|}{ Dejavnost } & \multicolumn{1}{|c|}{ Zagotavljanje kakovosti } & \multicolumn{1}{c|}{ Strokovni razvoj } \\
\hline $\begin{array}{l}\text { Definiranje dobrega } \\
\text { učenja in počutja ter } \\
\text { nivojev doseganja }\end{array}$ & $\begin{array}{l}\text { Jasni, nedvoumni standardi temelj- } \\
\text { ijo na raziskovalnih dokazih } \\
\text { Lokalno preverjeni, veljavni, } \\
\text { potrjeni }\end{array}$ & $\begin{array}{l}\text { Proces razvoja temelji na } \\
\text { skupnem razumevanju }\end{array}$ \\
\hline $\begin{array}{l}\text { Tehnike in postopki } \\
\text { evalviranja }\end{array}$ & $\begin{array}{l}\text { Evalvacijski dokument z vsemi } \\
\text { evalvacijskimi kriteriji } \\
\text { Ocenjevalci se držijo predpisanega } \\
\text { postopka } \\
\text { Postopki so nepristranski }\end{array}$ & $\begin{array}{l}\text { Oblikovan tako, da } \\
\text { omogoča najvišjo stopnjo } \\
\text { strokovnega učenja in refle- } \\
\text { ksijo prakse }\end{array}$ \\
\hline
\end{tabular}

${ }^{155}$ C. Danielson, T. L. McGreal, n. d. 


\begin{tabular}{|c|c|c|}
\hline Dejavnost & Zagotavljanje kakovosti & Strokovni razvoj \\
\hline $\begin{array}{l}\text { Seminarji za vzgojitelje } \\
\text { in ocenjevalce }\end{array}$ & $\begin{array}{l}\text { Ocenjevalci so konsistentni, ocene } \\
\text { temeljijo na dokazih, ocenjevalci so } \\
\text { zanesljivi } \\
\text { Dogovor med različnimi ocen- } \\
\text { jevalci }\end{array}$ & $\begin{array}{l}\text { Že sam proces usposabljan- } \\
\text { ja na seminarjih gradi na } \\
\text { konsenzu in razvija skupno } \\
\text { razumevanje }\end{array}$ \\
\hline
\end{tabular}

Preglednica 6: Združevanje zagotavljanja kakovosti in profesionalnega razvoja v procesu evalvacije vzgojitelja. ${ }^{156}$

${ }^{156}$ Prirejeno po: C. Danielson, T. L. McGreal, n. d. 


\section{In kaj nas čaka \\ v prihodnosti}

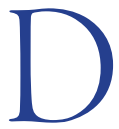

andanes je v obdobju hitrih sprememb napovedovati jutrišnji razvoj sila tvegana dejavnost. Vendar je to vsaj okvirno mogoče ob predpostavkah o tem, kako se bo razvijala znanost ter analiziranju trendov družbenega dogajanja, ki vplivajo na področje izobraževanja. Zanesljivo lahko predpostavljamo, da bo nevrološka znanost ponudila še bolj pomembne podatke o tem, kako delujejo specifični predeli možganov v povezanosti z vplivi okolja, ${ }^{1}$ hkrati pa nam bodo okoljske znanosti ponujale vse bolj kompleksno sliko in odgovore na vprašanja sodobne družbe. Predpostavljamo lahko tudi to, da bo vse večja osveščenost sodobnega človeka o ključnih problemih našega življenja in prihodnosti našega planeta še bolj okrepila združenja in zahteve po kakovostni vzgoji in izobraževanju za vse. Obstaja pa še vrsta družbenih zakonitosti, ki bodo področje močno zaznamovale $\mathrm{v}$ prihodnosti. Zelo tehten vpogled $\mathrm{v}$ sodobne trende na tem področju, ki jih na kratko predstavljamo v nadaljevanju, nam je ponudila zadnja analiza OECD-ja. ${ }^{2}$

\section{Demografska gibanja}

Glede na gibanje demografskih podatkov v razvitih državah ${ }^{3}$ lahko trdimo, da bo tudi v prihodnje prisotna manjša rodnost, višanje starosti staršev ob rojstvu otrok ter manjše število otrok v družini. Zanesljivo se bomo

\footnotetext{
${ }^{1}$ J. F. Mustard, Experience-based Brain Development: Scientific Underpinnings of the Importance of Early Child Development in a Global World, v: E. M. Young (ur.), Early Child development From Measurment to Action. A Priority for Growth and Equity, Washington D. C. 2007, 35-64; R. Shore, Rethinking the Brain: New Insights into Early Development. New York 1997.

${ }^{2}$ OECD, Trends Shaping Education, 2008.

${ }^{3}$ N.d.
} 
v zvezi s tem morali zamisliti, kaj pomeni za otroka imeti starejše starše in kako se bodo vzgojitelji in učitelji odzivali na njihove zahteve. Prav tako ni vseeno, če bodo $\mathrm{v}$ instituciji v večini primerov otroci, ki v domačem okolju nimajo socialnih izkušenj z brati in sestrami in si torej izkušnje z malo mlajšimi in malo starejšimi vrstniki lahko pridobijo le v instituciji. Manjše število rojstev lahko seveda povzroči manjši vpis otrok v vrtec in šolo. Ob tem bomo zanesljivo naleteli na pritiske $\mathrm{v}$ smeri zapiranja institucij na eni strani in zagovornike ugodnejšega razmerja med odraslimi in otroki v instituciji, da bi na ta način čim bolj izboljšali pogoje za razvijanje sposobnosti vsakega posameznega otroka.

Hkrati z upadanjem števila mlajše generacije se daljša življenjska doba, tako da se razmerje med generacijami, ki so lahko vključene v delo in tisti$\mathrm{mi}$, ki so z delom končale, vse bolj spreminja. Po podatkih OECD-ja ${ }^{4}$ je bil leta 2000 en človek v starosti več kot 65 let na pet ljudi v starosti od 15 do 65 let, sredi tega stoletja pa bo razmerje v korist delovne generacije le še ena proti dva. Če ob tem upoštevamo dejstvo, da se življenje po upokojitvi daljša, se bomo verjetno morali vse bolj ukvarjati tudi z vprašanji izobraževanja za starejše in temu $v$ procesu vseživljenjskega učenja nameniti resno pozornost. Strokovnjaki opozarjajo na potrebo redefiniranja obdobja šolanja, obdobja dela in obdobja upokojitve, ki naj ne bi bila tako linearna kot doslej in bi dopuščala lažje in pogostejše izhode iz sistema izobraževanja v delo in nazaj.

Tudi te spremembe bodo prinesle spremembe v družinskem življenju in $s$ tem $v$ zvezi usmerile pozornost na vprašanja, povezana $\mathrm{z}$ vzgojo in izobraževanjem otrok pa tudi varstva otrok, na katera se bodo morale institucije ustrezno odzvati. Vsekakor bo potrebno domisliti, kako potrebe (učne, socialne in kulturne) starejših vključiti v šolski sistem in kako izkoristiti njihove potenciale $\mathrm{v}$ šolskem sistemu. Nenazadnje bo potrebno v samem vzgojno-izobraževalnem procesu vprašanjem medgeneracijskega sožitja nameniti veliko več pozornosti, saj bo razmeroma maloštevilna generacija, ki bo delovno aktivna, s svojimi davki prispevala tudi za izobraževanje po celotni vertikali in za pokojninski sistem.

Svetovna populacija je samo v drugi polovici 20. stoletja narasla za polovico. Po pričakovanjih naj bi do sredine tega stoletja narasla še za tri milijarde, tako da bi na Zemlji živelo okrog devet milijard ljudi. Naraščanje populacije pa ni enakomerno razporejeno - medtem ko v državah OECD populacija upada, le-ta narašča $\mathrm{v}$ drugih, revnih in nerazvitih državah. Tako se razlike med bogatimi in revnimi deli sveta vse bolj povečujejo. $\mathrm{Ob}$ tem

${ }^{4} \mathrm{~N} . \mathrm{d}$. 
seveda razvite in bogate države svojo populacijo vse bolj izobražujejo, manj razvite in revne države pa ne morejo zagotavljati niti izobraževanja za vse, kot jim ga zagotavljajo deklaracije o človekovih pravicah. $\mathrm{Na}$ ta način izobraževanje na nek način prispeva $\mathrm{k}$ večanju razlik $\mathrm{v}$ svetovnem merilu. Mlade generacije se bodo s temi problemi soočale še bolj izrazito kot danes in ni vseeno, kako se bodo odzivali na te razlike.

Druga značilnost svetovne populacije pa je razmeroma intenzivno gibanje prebivalstva. Gibanja potekajo na dveh nivojih, na nivoju urbanizacije in na nivoju migracije. Na nivoju urbanizacije se bodo po predvidevanjih še vedno nadaljevala gibanja iz ruralnih v urbana okolja. Urbanizacija sicer prinaša napredek, vendar hkrati prinaša trganje tradicionalnih vezi in norm ter socialnih povezav, pa tudi osamo, ki ljudem prinaša drugačne probleme ter stresne situacije. Takšno preseljevanje ogroža vzgojno-izobraževalne institucije na podeželju, ki ostajajo prazne in hkrati zastavlja veliko vprašanj o tem, kako organizirati vzgojo in izobraževanje v prenatrpanih mestih, kako zagotoviti zdrav način življenja mladi generaciji, kako jim zagotoviti pogoje za gibanje ipd. Končno pa se zastavlja tudi vprašanje, ali lahko vzgojno-izobraževalna institucija postane neke vrste socialno sidro za vse, ki so pri tem ogroženi in jim pomaga premagovati občutke izolacije in izključenosti v prenatrpanih mestih ob selitvi iz ruralnega okolja, kjer so se srečevali z večjo povezanostjo. Ena temeljnih nalog vzgojno-izobraževalnih institucij bo usmerjena v ustvarjanje inkluzivnega okolja, v katerem se bo vsak posameznik v resnici počutil sprejetega, pomembnega in vsaj do neke mere uspešnega.

To je pomembno tudi zaradi tega, ker se bodo nadaljevala migracijska gibanja iz nerazvitih in revnih držav proti bolj razvitim in bogatim. Migracijska gibanja bodo še povečala pluralizem mikrokultur v instituciji, pa tudi pluralizem pričakovanj staršev v odnosu do učenja in vzgojiteljev oziroma učiteljev. Tak pluralizem je danes pravzaprav že realnost. Profesor Klaus Fröhlich-Gildhoff je na nedavnem srečanju predstavil izkušnje vrtca v Frankfurtu, kjer v skupini osemnajstih otrok otroci govorijo sedemnajst različnih jezikov. ${ }^{5}$

Občutek izključenosti in negotovosti migrantskih skupin s hkratnim premagovanjem kulturnih razlik postavlja migrantske skupine otrok in njihovih staršev v neenake pogoje v odnosu do izobraževanja. Vzgojno-izobraževalne institucije seveda same ne bodo zmogle postoriti vsega potreb-

${ }^{5}$ Klaus Fröhlich-Gildhoff, Promotion of life skills, mental health and resilience in early childhood institutions - Presentation of national situation in Germany, International workshop, Frankfurt 2009. 
nega za resnično interkulturnost $\mathrm{v}$ praksi, lahko pa postorijo marsikaj za to, da v svojih okoljih ustvarjajo socialno inkluzivno okolje ob predpostavki, da se tudi v skupnosti tem vprašanjem namenja ustrezna skrb.

\section{Spremembe v družini}

Značilna dvogeneracijska družina z zaposlenim očetom in materjo, ki je skrbela za dom in je bila značilna za razvite dele sveta v prvi polovici 20. stoletja, se v sodobnosti spreminja. Za sodobna gibanja na tem področju je značilno, da so matere vse bolj zaposlene, da se število porok manjša na račun povečanja števila družinskih skupnosti. Vse več je ločitev in posledično enostarševskih družin. Delež teh je v razvitih družinah narasel kar na 20 do 25 odstotkov. $^{6}$ Končno pa otroci rastejo tudi v istospolnih družinskih skupnostih. Za sodobne družine je značilna tudi večja različnost družinskih kultur kot posledica migracijskih gibanj. Otroci živijo v izrazito kompleksnih družinskih okoljih (z ločenimi starši, z enim ali obema roditeljema in njihovimi novimi partnerji, ob selitvi od enega k drugemu staršu ali pa v zelo tradicionalnih družinskih vzorcih (priseljenci), s starši, ki prihajajo iz različnih kultur ipd.). To prinaša otrokom množico čustvenih in socialnih zagat, ki jih morajo prebroditi. Vzgojno-izobraževalne institucije pa postavlja pred nove izzive $v$ oblikovanju odnosov $z$ družinami in delitvi odgovornosti za otroke.

Sodobna družina v razvitem svetu je obremenjena tudi z željo po materialnem blagostanju, ki še vedno ostaja ena od najbolj pomembnih vrednot sodobnega človeka, ${ }^{7}$ kar zaradi obremenitve povzroča manj socialnih povezav z okolico in upadanje smisla po pripadanju neki skupnosti. Pri tem pa je zanimivo, da se povečujejo virtualne oblike povezovanja v najrazličnejše mreže, ki ljudem nudijo socialne povezave. Človek bo namreč vedno težil k povezovanju z drugimi, kar nam $\mathrm{v}$ končni meri dokazujejo tudi drugačne oblike povezovanja, ki jih je razvil v sodobnem svetu. Vse to se prenaša tudi na vzgojno-izobraževalne institucije, čeprav te po obliki organiziranja temeljijo na združevanju. Negovanje socialnih stikov, medsebojnega zaupanja in kvalitetnih odnosov med vsemi, ki se vključujejo v življenje institucij, bo zato tudi v bodoče velik izziv, saj kvalitetni odnosi vplivajo na uspešnost učenja.

Zaradi vse večjega vključevanja žensk v trg dela bo potreba družin po varstvu v času odsotnosti staršev vse večja. Institucije pa se bodo morale še bolj približati potrebam družin in otrok. Končno z množičnim pose-

${ }^{6}$ OECD, Trends Shaping Education, 2008.

${ }^{7}$ N.d. 
ganjem žensk v trg dela prihaja do feminizacije nekaterih področij dejavnosti, kot so izobraževanje, medicina, pravo ipd. Za področje izobraževanja je pojav feminizacije poklica vsekakor zaskrbljujoč in terja iskanje mehanizmov, ki bodo $\mathrm{v}$ poklic ponovno privabili moške, da bi tako ustvarili primerno uravnoteženost $\mathrm{v}$ modelih, s katerimi se otroci srečujejo. Vsi pa bomo morali, ne glede na prevladujoči spol v tem poklicu, prispevati k večjemu ugledu samega poklica.

\section{Vrednote}

Svetovna študija vrednot je pokazala, da so vrednote v različnih delih sveta različne, da pa ljudje, ki so bili rojeni v letih blaginje, bolj cenijo samoekspresijo, kakovost življenja, manj pa tradicionalne vire avtoritete kot so religija, družina, država. Prevladujejo posvetne vrednote, manj je verskega angažmaja, manj spoštovanja avtoritete, večja toleranca do ločitve, do abortusa, evtanazije, manj pa je nacionalizma. Manj je poudarka na ekonomski in fizični varnosti in več je poudarka na dobrem počutju in kakovosti življenja. Manj je cenjena marljivost in trdo delo, bolj pa ustvarjalni duh in tolerantnost.

Ob naštetem se lahko vprašamo, kaj pomeni na področju vzgoje in izobraževanja dejstvo, da je avtoriteta tako nepomembna, kakšne posledice ima to za socialno dinamiko v razredu, za vlogo vzgojitelja in učitelja. Kakšne spremembe v vzorcih delovanja potrebujejo vzgojitelji in učitelji? Drugo vprašanje pa je povezano z dilemo, ali otrokom nudimo dovolj možnosti za izražanje samega sebe in v kolikšni meri bodo pripravljeni na to, da bodo sodelovali z ljudmi z različnimi vrednotami.

\section{Klimatske spremembe}

Še ne tako daleč nazaj so klimatske spremembe pripisovali predvsem spreminjanju kota kroženja zemlje in oddaljenosti od sonca. Danes strokovnjaki z zanesljivostjo trdijo, da kar v devetdesetih odstotkih na ta pojav vpliva človek z nepremišljenim krčenjem gozdov, uporabo goriv, ki onesnažujejo ozračje ter $\mathrm{z}$ vse večjim prometom v zraku in na zemlji. ${ }^{8}$ Opozarjajo nas na naraščanje temperature, kjer dolgoročno celo spremembe za eno stopinjo lahko povzročijo neravnovesja. Ob predpostavki, da bo temperatura narasla za dve ali tri stopinje do konca tega stoletja, bo že sredi tega stoletja izumrlo 15 do 30 odstotkov vrst živega sveta. Kljub resnim opozorilom se zdi, da nas ta opozorila in celo vedenje o problemu ne privedejo do spremembe našega delovanja. Ob tem bo naloga vzgojno-izobraževalnih insti-

${ }^{8} \mathrm{~N} . \mathrm{d}$. 
tucij usmerjena $\mathrm{k}$ oblikovanju zavesti o ogrožanju skupne prihodnosti in $\mathrm{k}$ spreminjanju obnašanja, ki bo usklajeno $\mathrm{z}$ vedenjem. Navade na uporabo dobrin, ki jih je danes še v izobilju (voda, elektrika, goriva), bo potrebno spremeniti tako, da bodo v soglasju z navadami in vrednotami odgovornega Zemljana, ki niso škodljive za razvoj.

\section{Globalna ekonomija}

Čeprav se globalna ekonomija trenutna nahaja v veliki krizi in doslej še ni znanega modela, ki bi jo uspel premagati, bo tudi v bodoče pričakovati naraščajočo konkurenco na svetovnem trgu. Trenutno najbolj hitro rastoče ekonomije kot so kitajska in indijska, bodo tudi v bodoče privlačile investitorje zaradi milijonov poceni in dostopne delovne sile, ki je povrhu vsega še dobro izobražena. Investicije pa s seboj prinašajo nove tehnologije in $\gg$ know how «, kar ponovno vpliva na hiter ekonomski razvoj. Nacionalne izobraževalne politike se bodo morale soočiti z globalnimi ekonomskimi gibanji in iskati tiste sposobnosti, ki bodo spodbujale inovativnost in tako ohranile doseženo stopnjo ekonomskega razvoja $\mathrm{v}$ že razvitih državah. Več poudarka pa bo v izobraževanju veljalo nameniti tudi spoznavanju drugih (neevropskih) kultur, zgodovine, jezikov in tako mladim generacijam $\mathrm{v}$ danes razvitem svetu omogočiti ustrezno komunikacijo s hitro razvijajočimi okolji.

\section{Svet dela in poklicev}

Delo bo v prihodnje vse manj dominantno v življenju posameznika. Tudi v bodoče lahko pričakujemo nižanje dnevne delovne obveznosti. Tudi dolžina delovne kariere je v preteklosti padala predvsem na račun daljšanja šolanja in zgodnjih upokojitev. Toda v nasprotju s tem se potovanje od doma na delovno mesto in nazaj daljša, služba je bolj stresna in intenzivnost dela večja. $\mathrm{Na}$ račun krajšanja delovne obveznosti se podaljšuje prosti čas, ki je večinoma namenjen dejavnostim s področja rekreacije, kulture in različnim formalnih in neformalnih oblikam izobraževanja. Temu se bo morala odzvati tudi politika izobraževanja in ponujati kratka izobraževanja, ki se skozi čas nadgrajujejo.

Že nekaj časa govorimo tudi o tako imenovani učeči se družbi. Pojem temelji na spoznanju, da se vse več ljudi vse bolj izobražuje. Trditev potrjuje dejstvo, da je danes v razvitih državah med ljudmi v starosti od 55 do 64 let en človek od petih z višjo izobrazbo, med ljudmi v starosti od 25 do 34 let pa eden od treh. Mlada generacija se torej vse bolj izobražuje, pri tem pa so v izobraževanje bolj vpete ženske kot moški. Vrtci in šole imajo tako kot 
partnerje vse bolj izobražene starše, ki pa jih ne znajo najbolj ustrezno izkoristiti v smislu poslanstva vrtca in šole.

Trajnost zaposlitve se nagiba $\mathrm{v}$ oblike zaposlovanja za določen čas in $\mathrm{v}$ »part time« zaposlitve. Zanesljivost zaposlovanja postaja vse bolj relativna, ostaja pa odprto vprašanje, kako so mlade generacije pripravljene na to dejstvo. Na drugi strani pa ostaja tudi vprašanje, ali se bodo vrtci in šole znali ustrezno odzvati na tako spremenjene potrebe staršev.

\section{Investicije v izobraževanje}

Po podatkih OECD-ja ${ }^{9}$ v večini razvitih držav investicije v izobraževanje naraščajo. Problem pa nastaja ob spoznanju, da višje investicije še ne pomenijo boljših rezultatov. Tako npr. Finska, ki se je na mednarodnih primerjalnih študijah PISA uvrstila na sam vrh po uspešnosti rezultatov svojih učencev, investira v izobraževanje mnogo manj kot Švedska, ki je po rezultatih močno zaostajala za Finsko. Zato je verjetno izjemno pomembno vprašanje $\mathrm{v}$ zvezi z investicijami, kako so le-te porabljene, oziroma na kakšen način naj bodo uporabljene, da se bodo najbolj učinkovito povrnile. Po mnenju Heckmana in njegovih sodelavcev ${ }^{10}$ naj bi vlade preusmerile investicije za oblikovanje zmožnosti proti predšolski vzgoji, v nasprotju $s$ tem, kar počnejo sedaj, ko so investicije večje v kasnejših stopnjah izobraževanja. Pri tem se ne zavzemajo za investiranje v zgodnja leta - še posebej za ogrožene skupine otrok, tem investicijam pa bi morale slediti investicije tudi na drugih stopnjah izobraževanja, da bi bilo izobraževanje učinkovito.

\section{Informacijsko-komunikacijska tehnologija}

Informacijsko komunikacijska tehnologija je eno tistih področij, ki se je v sodobnem času bliskovito razvijalo. Postala je hitrejša, manjša, cenejša in široko dostopna. K njenemu razvoju je v zadnjem času še posebej prispeval hitro rastoči svetovni splet, ki postaja vse bolj pomemben vir informacij, prostor za oblikovanje lastne vsebine in možnost povezovanja. Generacije otrok, ki rastejo v tem okolju, so ponavadi mnogo bolj spretne v uporabi informacijsko komunikacijske tehnologije kot starejša generacija in tako nastane razkorak med učenjem $\mathrm{v}$ instituciji in digitalnim učenjem. Institucije običajno počasi organizirajo učenje tako, da to dejstvo upoštevajo. Še vedno ne vemo vsega o tem, kako informacijsko komunikacijska tehnolo-

\footnotetext{
${ }^{9}$ N.d.

${ }^{10}$ Flavio Cunha, James J. Heckman, A new framework for the Analysis of Inequality. NBER Working paper 12505, Cambridge, Massachusetts 2006.
} 
gija v resnici vpliva na otroke. Odprto ostaja vprašanje povezanosti informacij na spletu z obstoječimi modeli organizacije znanja v discipline, ki je značilno za šolsko učenje.

\section{Politična participacija}

Pripravljenost ljudi za politično participacijo se v sodobnem razvitem svetu spreminja. Pri tem upada udeležba na volitvah, članstvo v političnih strankah pa se viša, viša pa se tudi participacija v drugih oblikah političnega delovanja (podpisovanje peticij, demonstracije, bojkoti ipd.). Izobraževanje za odgovorno in aktivno državljanstvo je osnovno za vsak sistem izobraževanja, vendar še vedno ostaja vprašanje, kako v instituciji krepiti državljansko pismenost in jo postaviti ob bok z drugimi prioritetami vzgoje in izobraževanja. To postavlja pred vzgojno-izobraževalne institucije poseben izziv, saj se participacije ni mogoče učiti, če že od zgodnjih let nimaš pogojev za aktivno participacijo $\mathrm{v}$ procesih sprejemanja odločitev v vsakodnevnem življenju.

\section{Privatizacija}

Procesi decentralizacije in privatizacije so vplivali tudi na področje vzgoje in izobraževanja. Prinašajo pa prenos socialnih odgovornosti na ramena privatnikov ali družb. $S$ tem se sicer veča ponudba, ostaja pa vprašanje, ali imajo posamezniki spretnosti, ki jim omogočajo dobro izbirati med ponujenimi zdravstvenimi, upokojitvenimi, finančnimi servisi ter univerzitetnimi programi, ki so bili doslej v pristojnosti in odgovornosti države. Posebej pereče pa ostaja vprašanje, kako bo z zagotavljanjem enakosti oziroma zagotavljanja enakih možnosti, če bo izobraževanje podvrženo privatizaciji.

\section{Družba blaginje in družba revščine}

Rastoča blaginja ima vpliv na naše navade, vrednote in stališča, hkrati pa se človek vse bolj osvobaja od materialnih potreb in usmerja k osebnemu razvoju in svobodi. Pričakovati je, da se z blaginjo spreminja tudi odnos do izobraževanja in mu postavlja nove izzive. Seveda pa ostaja vprašanje, ali bo blaginja stalnica v našem družbenem razvoju in ali mlade generacije pripravljamo tudi na drugačne pogoje. Navade v uporabi dobrin, ki jih je danes še v izobilju (voda, elektrika, goriva), bo potrebno spremeniti tako, da bodo v soglasju z navadami in vrednotami odgovornega Zemljana, ki niso škodljive za razvoj. 
Neenakost med ljudmi se veča. Še pred drugo svetovno vojno je najbogatejših tisoč ljudi zaslužilo približno 4 do 8 odstotkov vseh prihodkov. Ta delež se po vojni zmanjša na približno 2 odstotka, vendar se v začetku osemdesetih let začne ponovno zviševati. ${ }^{11}$ Razkorak med tistimi zelo bogatimi in drugimi se vse bolj povečuje in po nekaterih analizah naj bi prav kopičenje kapitala okrog peščice posameznikov povzročilo sedanjo ekonomsko krizo. Pohlep posameznikov je večino prebivalstva pahnil v še večjo revščino. Revščina, ki je kombinirana z nizko stopnjo izobraženosti staršev, pa ima v najzgodnejših mesecih in letih življenja mnogo večji vpliv na otrokov razvoj kot kadarkoli kasneje v življenju.

In če povzamemo in zaključimo, lahko trdimo, da potrebnega znanja in spretnosti, ki jih ljudje potrebujejo, ali jih bodo potrebovali v 21. stoletju, ne moremo pridobiti v vzgojno-izobraževalni instituciji, ki deluje po modelu tekočega traku in ne izrablja prednosti možganskih zmožnosti za učenje. Prav tako že danes na področju proizvodnje in poslovanja ne moremo več govoriti o stabilnosti in predvidljivosti, ampak se soočamo s spremenljivostjo in dinamičnostjo. Opravila, ki jih bo v bodoče opravljal človek na delovnem mestu, bodo omejena predvsem na tista, ki jih roboti ne bodo zmogli, kar pomeni, da ne bomo potrebovali posameznikov, ki bodo usposobljeni za mehanično delo, ampak posameznike, ki bodo znali upravljati sami sebe. Znati bodo morali reševati probleme, odločati in sprejemati odločitve, se dogovarjati; biti bodo morali odprti, fleksibilni, iznajdljivi in domiselni. Soočiti se bodo morali z negotovostjo, $s$ kompleksnostjo, globalizacijo, eksplozijo informacij, z drugačnimi tehnologijami, z veliko različnimi kulturami, kljub temu pa bodo morali uravnavati in vzdrževati določene vrednote in stališča, ki krepijo zadostno stopnjo stabilnosti posameznika, integritete in socialne harmonije (Caine, Caine, 1994). Zametki teh zmožnosti pa se oblikujejo prav na začetku življenja človeških bitij, zato bo predšolska vzgoja tudi v bodoče morala slediti družbenim spremembam. Z zanesljivostjo lahko tudi predvidevamo, da bodo znanstvena spoznanja v nevrologiji in genetiki odkrila še marsikaj, kar sedaj samo predvidevamo. Tudi ta spoznanja bodo zaznamovala našo prihodnost. In končno bomo usmerjeni tudi v zagotavljanje in uresničevanje otrokovih pravic za vse otroke od rojstva naprej in podpiranje starševskih kompetenc. Za uresničevanje teh idej pa bomo potrebovali učinkovito zagovorniško politiko na lokalni in globalni ravni.

${ }^{11}$ OECD, Trends Shaping Education, 2008. 

bstraktno mišljenje: sposobnost razrešiti različne probleme na abstraktnem nivoju, ne da bi potrebovali konkretnih objektov.

Aktivno učenje: pristop $\mathrm{k}$ učenju, $\mathrm{v}$ katerem so otroci aktivni iskalci znanja in ne pasivni sprejemniki znanja.

Avtonomija: razvoj občutka in mnenja o sebi ter ponosa nad svojimi dosežki.

Behaviorizem: teorija, ki pripisujevse razvojnespremembevplivom okolja.

Certifikacija: proces, v katerem se posamezniku prizna, da izpolnjuje specifičen niz kriterijev.

Cona bližnjega razvoja: po Vigotskem je to razdalja med tem, kar otrok trenutno zmore in tem, kar bi potencialno zmogel ob pomoči bolj kompetentnega oziroma bolj razvitega otroka ali odraslega.

Družinska kultura: družinsko okolje, ki vključuje vrednote, prepričanja, cilje, navade in vzgojne stile v družini.

Države v tranziciji: države, ki prehajajo iz ene državne ureditve v drugo - npr. države, ki se iz Zveze držav osamosvojijo ali prehajajo iz enega političnega sistema $\mathrm{v}$ drugega.

Formativna evalvacija: neprekinjeno spremljanje in ocenjevanje z namenom sprotnega spreminjanja in razvoja, ki vodi k zastavljenim ciljem.

Holistični pogled na otroka: vidik, ki vključuje otrokov razum, telo, čustva in osebni kontekst kot neločljivo celoto. 
Indikator: kazalnik ali mera, ki opisuje učinkovitost. Definiran je tako, da obstaja glede definicije skupen dogovor.

Inkluzivno okolje: okolje, ki omogoča vsakemu posamezniku, da uresničuje svoje potenciale in se pri tem počuti kot zaželen in pomemben član skupnosti.

Integriran prostop: pristop, ki uresničuje vsebino kot celoto in ne po posameznih področjih ali predmetih.

Klasično pogojevanje: učna tehnika, v kateri dražljaj, ki običajno izzove refleks, povežemo z dražljajem, ki ponavadi ne izzove refleksa, dokler le-ta kasneje sam ne izzove refleksa.

Kompetenca: niz znanj, veščin in stališč, ki so pomembne za uspešno življenje in delovanje v skupnosti.

Konstruktivistični pristop: pogled na razvoj in učenje, ki temelji na delu Piageta in predpostavlja, da otrok ne sprejema znanja pasivno, medtem ko ga učijo, ampak ga sam aktivno konstruira.

Mentalna reprezentacija: zmožnost predstaviti si nekaj v mislih.

Modeliranje: strategija, v kateri odrasli prenašajo določeno vedenje ali obnašanje na otroka tako, da jih ta v tem zavedno ali nezavedno posnema.

Multikulturnost (večkulturnost): pristop k vzgoji in izobraževanju, ki sprejema in spoštuje kulturno različnost in prispeva k pluralistični družbi.

Na otroka osredinjen kurikulum: pedagoška filozofija, ki jo je začel Dewey in pri oblikovanju kurikula izhaja bolj iz koristi otrok kot pa posameznih predmetov.

$\mathrm{Na}$ otroka osredinjeno učenje: proces učenja in poučevanja, $\mathrm{v}$ katerem se otrok uči iz interakcije z okoljem, drugimi otroki in odraslimi. Ta način učenja je v nasprotju $\mathrm{z}$ učenjem, $\mathrm{v}$ katerem je pedagogova osnovna vloga poučevanje specifične snovi.

Nativistična teorija: teorija, ki dednosti in genom pripisuje glavno vlogo v učenju in razvoju.

Odprta vzgoja: program, ki temelji na predpostavki, da so otroci zmožni izbirati in se učiti iz primernih aktivnosti, če se jim zagotovi dobro premišljeno okolje.

Partnerstvo: odnos, ki temelji na medsebojnem spoštovanju in enakomerni porazdelitvi moči pri sprejemanju odločitev.

Portfolio: eno od orodij za pristno in verodostojno ocenjevanje in spremljanje. To je izbor del, iz katerih se lahko ocenjuje procese in rezultate. 
Profesionalni razvoj vzgojitelja: proces, v katerm dograjujemo znanje, spretnosti in vrednote. Postajamo reflektivni in vse bolj vključeni v aktivnosti, ki podpirajo poklic vzgojitelja in dobro vseh otrok.

Progesivna pedagogika: pedagogika, ki jo je zagovarjal Dewey in njegovi nasledniki. Podpira idejo, da pedagog dela v korist otrok in idejo, da mora edukacija poudarjati aktivno učenje ob stvarnih realnih izkušnjah. Predstavlja gibanje za bolj demokratične in na otroka osredinjene pristope v izobraževanju, v nasprotju s hierarhičnimi in didakticiranimi pristopi.

Različnost: lastnosti in pogoji, ki so različni od naših lastnih ali tistih, ki jih ima skupina, ki ji pripadamo, in so prisotni pri drugih posameznikih in skupinah.

Razvojno primerna praksa: praksa, ki upošteva otrokove individualne, razvojne in kulturne značilnosti.

Refleksija: način, s katerim pregledujemo in raziskujemo svojo lastno izkušnjo - sedanjo in preteklo - z namenom, da bi jo razumeli, se iz nje učili in rasli.

Reševanje problemov: proces, $\mathrm{v}$ katerem uporabljamo psihične in socialne spretnosti, s katerimi spodbujamo in usmerjamo otroke pri oblikovanju ali iskanju rešitev.

Smiselno učenje: praksa, v kateri otrok konstruira znanje z iskanjem smisla v svojih izkušnjah.

Sociokulturna teorija: teorija, ki jo je razvil Vigotski in je usmerjena na učinke kulturnega konteksta na razvoj in učenje.

Sumativna evalvacija: ocenjevanje, ki nam daje odgovor o tem, v kolikšni meri so cilji doseženi.

Učeća se skupnost: skupina ljudi, ki si deli skupne vrednote in prepričanja ter je aktivno vključena v skupno učenje.

Ǔ̌na izkušnja: po Deweyu je učna izkušnja aktivnost, ki ji lahko pripišemo pet kriterijev: zasnovana je na otrokovih interesih in raste iz njegovega obstoječega vedenja in izkušenj, podpira otrokov razvoj, pomaga otroku razviti nove spretnosti, prispeva k otrokovemu razumevanju sveta ter pripravlja otroka za bolj polno življenje.

Ǔ̌no okolje: fizično in socialno-emocionalno okolje, $\mathrm{v}$ katerem poteka učenje.

Vseživljenjsko učenje: učenje, ki poteka skozi vse življenje in je motivirano z osebnimi ali profesionalnimi razlogi. 
Zanesljivost ocenjevanja: merilo, ki kaže, da je ocenjevanje stabilno in konsistentno.

Zidarski oder: nudenje zidarskega odra je način opore, ki pomaga otroku $\mathrm{k}$ nadaljnjemu razumevanje določenega pojma, pojava. 


\section{Povzetek}

P.

o zagotovilih znanstvenikov naj bi se človeška vrsta začela razvijati pred dvesto tisoč leti, da bi nekako pred deset tisoč leti pristala $\mathrm{v}$ obdobju poljedelske revolucije. Samo v zadnjih dvesto letih pa smo iz poljedelsko-obrtniške družbe prešli v industrijsko in sodobno informacijsko družbo. To kaže, da je bilo človeštvo sicer že od nekdaj podvrženo določenim spremembam, ki so se pojavljaje včasih hitreje, včasih počasneje, toda nikoli tako hitro kot v zadnjih dvesto letih. Videti je, da se proces spreminjanja vse bolj stopnjuje. Sodobnemu človeku prinašajo vse več izzivov hiter razvoj znanosti in tehnologije, spremembe v proizvodnji, ekonomiji in trženju, hiter tehnološki razvoj, politične spremembe, ki jih dopolnjujejo še visoka rast svetovne populacije, staranje populacije, migracijski procesi, klimatske spremembe in omejeni viri energije, vode in hrane, ki so potrebni za preživetje ter nenazadnje globalna medsebojna ekonomska odvisnost. In vse to neposredno vpliva tudi na spremenjena pričakovanja v odnosu do vzgoje in izobraževanja $\mathrm{z}$ vidika sistemskih rešitev, ciljev in procesov.

Pojav hitrih sprememb in novih izzivov v zadnjih 200 letih je prisoten tudi na področju predšolske vzgoje. Zbrano gradivo ponuja uvid v razvoj organizirane predšolske vzgoje in v razvoj pedagoških idej, ki so se ob dejavnosti pojavljale od njenih začetkov do danes. Pri tem pod pojmom organizirana predšolska vzgoja razumemo vse oblike vzgojnih in izobraževalnih prizadevanj, ki potekajo izven otrokovega doma. Dejavnost je v pičlih 200 letih od svojih začetkov do danes prešla različna obdobja, ki odražajo družbene razmere, vrednote $\mathrm{v}$ določeni družbi, odnos do otroštva in doseženo stopnjo razvoja znanstvenih dosežkov. 
V gradivu predstavljamo razvoj dejavnosti od njenih začetkov v obdobju začetkov industrializacije, ko je področje odgovarjalo redkim humanističnim nagibom za zaščito otrok pred izkoriščanjem in zgodnjim vključevanjem otrok v delo ter revščino in nenazadnje zagotavljanju varstva otrokom ob zaposlovanju staršev izven njihovega doma v pogojih industrializacije. Predstavljamo prve znanstvene zasnove, ki jih je področje dobilo šele na koncu 19. in v začetku 20. stoletja v obdobju gibanja za študij otroka in progresivne pedagogike, ki so bile usmerjene zlasti na upoštevanje zakonitosti otrokovega razvoja ter ustvarjanje pogojev za smiselno učenje. Opisujemo razloge za zastoj v razvoju dejavnosti pred, med in po drugi svetovni vojni ter opozarjamo na izrabljanje organizirane predšolske vzgoje za nadzor nad družinsko vzgojo in skrb za uresničevanje državno zastavljenih ciljev vzgoje in izobraževanja. Posebno pozornost namenjamo ponovnemu razcvetu področja $\mathrm{v}$ šestdesetih letih 20. stoletja, ki jih označujejo poglobljene znanstveno zasnovane zasnove in odzivi na družbena prizadevanja za odpravo posledic revščine in socialne neenakosti ob poudarjanju vplivov okolja in otrokovih potreb.

Največ pozornosti v gradivu posvečamo sodobnim procesom in idejam, ki so področje utrdili na prehodu iz 20.v 21. stoletje. Podrobneje smo opredelili družbena dogajanja in spremembe znanstvenih paradigem, ki vplivajo na vzgojo in izobraževanje. Pri tem smo se omejili na tiste pedagoške ideje, znanstvene dosežke in koncepte, ki so še posebej zaznamovali pojmovanja na področju predšolske vzgoje. Slednji so svojo osnovo dobili v Konvenciji o otrokovih pravicah ter sodobnih spoznanjih o razvoju možganov in spoznanjih o pomembnosti tega obdobja življenja za nadaljnji razvoj posameznika in družbe v celoti. Področje osvetlimo tudi z vidika sodobnega razumevanja kakovosti z vidika otrok, staršev, širše skupnosti in izvajalcev. Posebno pozornost pri tem namenjamo tudi profesionalnemu razvoju in njegovi vlogi pri zagotavljanju kakovosti.

Prikaz zaključujemo s pogledom v prihodnost in opozorimo na ključne dejavnike in predpostavke o razvoju družbenih razmer na tistih področjih razvoja, ki že od nekdaj močno zaznamujejo področje vzgoje in izobraževanja, kot so predvidene spremembe družine, svet dela in poklicev, participacija, demografska gibanja ipd. in bodo zahtevale iskanje ustreznih odgovorov tudi na področju organizirane predšolske vzgoje.

Razumevanje družbenega konteksta, idej, strokovnih in znanstvenih spoznanj, kot so nastajala in se razvijala skozi zgodovino do današnjih dni, nam pomaga razumeti in ocenjevati sodobna dogajanja na tem področju in jih umestiti v širši družbeni kontekst dogajanja po svetu. Na ta način že- 
limo preseči in odpirati ozke poglede na dejavnost, kar je še posebej pomembno v sodobnih procesih globalizacije in času hitrih sprememb, ki izvajalce in uporabnike, strokovnjake in politike v tej dejavnosti bolj kot kdaj koli doslej soočajo z novimi izzivi. 

ccording to the findings of scientists, the human species has start-
ed developing two hundred thousand years ago and has reached the era of agricultural revolution approximately ten thousand years ago. During the last two hundred years, humans have evolved from agricultural-tradesman's society into industrial and modern information society. This shows that mankind has always been subject to certain changes, which took place sooner or later, however, never as fast as in the last two hundred years. It seems that the process of changing is increasing. The modern man has to face more and more challenges, which are caused by rapid scientific and technological development, by changing production, economy and marketing, as well as by political changes influenced by a large growth of the world's population, the aging of population, processes of migration, climate changes and a limited amount of energy, water and food, all necessary for our survival, and last but not least by mutual global economic dependency. All this directly influences the changing expectations towards education from the aspect of systematic solutions, goals and processes.

During the last 200 years, rapid changes and new challenges have also taken place in the field of preschool education. The gathered material gives an insight into the development of organized preschool education and into the development of educational ideas that have supported preschool education from it's beginnings until today. The concept of organized preschool education includes all forms of educational efforts, which take place outside a child's home. In only 200 years, from its beginnings until today, this activity has gone through different periods that reflect social condi- 
tions, values within a certain society, attitudes towards childhood and the reached level of scientific achievements.

In the material, we deal with the development of preschool education from its beginnings in the first years of industrialization, when this field defended rare humanistic principles for the protection of children from exploitation, child-labour and poverty and provided child-minding facilities for children of employed parents. We describe the first scientific approaches in this field, which were developed only at the end of the 19th and at the beginning of the 20th century with the Child Study Movement and progressive pedagogy. They focused on the implementation of the child development theory and tried to create conditions for sensible learning. We then describe the reasons for a halt in activity's development before, during and after the Second World War and warn about the abuse of organized preschool education for gaining control of family education and the concern for the realization of educational goals, that were set by the government. We especially focus on the revival of this field in the sixties of the 20th century, which were characterized by a profound scientifically based approach and reactions to social efforts to remove the consequences of poverty and social inequality by stressing the influence of the environment and children's needs.

The greatest focus in the material is placed on modern processes and ideas that have strengthened this field during the transition from the 20th to the 21 st century. What is more, we give detailed definitions of social findings and changes of scientific paradigms that influence education. Thereby, we have limited ourselves to those pedagogical ideas, scientific achievements and concepts that have especially influenced the conception in the field of preschool education. The latter were based on the Convention of the Rights of the Child, modern findings about brain development and about the importance of this period in life for further development of individuals and society in general. Furthermore, the topic is also addressed from the aspect of contemporary understanding of quality from different points of views: the view of children, parents, broader community and the providers of preschool education. A special focus was put on professional development and its role at ensuring quality.

The review ends with a look into the future. We point out the key factors and assumptions about future development of social conditions in the fields of development that have always had an influence on education (like anticipated changes in a family, the working and professional world, par- 
ticipation and demographic movements etc.) and will require appropriate answers in the field of organized preschool education.

Understanding of social context, ideas, professional and scientific findings and their development through history helps us understand and judge contemporary findings in the field of preschool education and place them into a broader context of development around the world. In this way, we wish to overcome and broaden the narrow views about preschool education. This is of great importance in contemporary globalisation processes and rapid changes, because of which people (providers, users, experts and politicians) have to face more challenges than ever before. 



\section{Viri in literatura}

21st century learning initiative, Executive summary, initiative synthesis. Washington D. C. 1997

National commission on excellence in education, A Nation at Risk. 1983 Abbott, John, To be intelligent. Educational Leadership 54/6 (1997), 6-10.

Abrami, Phillip C., Apollonia, Sylvia, The dimensionality of ratings and their use in personnel decisions. V: Student ratings of instruction: Issues for improving practice. Ur. M. Theall, J. Franklin. Jossey-Bass, San Francisco 1990, 97-103.

Airasian, Peter, Gullickson, Peter, Teacher Self-Evaluation. V: Evaluating teaching: A guide to current thinking and best practice. Ur. Stronge. Corwin Press, 1997.

Alexander Hamilton Institute, Effective interviews for every situation. Modern Business Reports, Ramsey, New York 1995.

American psychological association, Presidential Task Force on Psychology in Education. Learner-centred psychological principles: Guidelines for School redesign and reform. Washington D. C. 1993.

Amonašvili, Šalva A., V školu š šesti let. Prosvješčenije, Moskva 1986.

Amonašvili, Š. A., Zdravstvujte djeti. Prosvješčenije, Moskva 1983.

Anderson, Gordon C., Barnett, Jean G., Characteristics of effective appraisal interviews. Personal Review 16/4 (1987), 18-25. 
Andersson, Bengt-Erik, Effects of day care on cognitive and socio-emotional competence in thirteen years old Swedish schoolchildren. Child Development 63 (1992), 20 - 36.

Andersson, B.-E., Effects of public day care: a longitudinal study. Child Development 60 (1989), 857-866.

Association for supervision and curriculum development, Promoting social and emotional learning: Guidelines for educators. Author, Alexandria, VA 1997.

Barth, RolandS.,ImprovingSchoolsfrom Within. Teachers, parents, andprincipals can make the difference. Jossey-Bass Publisher, San Francisco 2000.

Bečaj, Janez, Doseganje popolne kakovosti - cilj za naslednjo petletko? V: Kakovost preduniverzitetnega izobraževanja, Zbornik posveta. Ur. B. Marentič Požarnik in drugi. Zavod Republike Slovenije za šolstvo, Ljubljana 1996.

Belsky, Jay, Two waves of day care research: Developmental effects and condition of quality. V: The child and day care setting. Ur. Ainskie. Praeger, New York 1984.

Belsky, J., The »effects « of infant day care reconsidered. Early Childhood Research Quarterly 3 (1988), 235-272.

Bennett, John, Early Childhood Services in the OECD Countries. Innocenti working paper. UNICEF, Innocenti Research Centre 2008.

Bennett, J., Public policy in Early Childhood in Europe. 6 challenges for the coming years. Uvodni referat na EECERA Conference. Stavanger september 2008, 3-6.

Bergant, Milica, Teme izpedagoške sociologije. Cankarjeva založba, Ljubljana 1970.

Berger, Eugenia Hepworth, Parents as Partners in Education. Families and schools working together. Merill, Prentice Hall 2000.

Berk, Laura E., Winsler, Adam, Scaffolding Children's learning: Vygotsky and Early Childhood Education. NAEYC, 1995.

Berrueta-Clement, John R., Schweinhart, John R., Barnett, William Steven, Epstein, Ann S., Weikart, David P., Changed Lives: the effects if the Perry Preschool Programme on youths through age 19. The High/Scope Press, Ypsilanti, Michigan 1984.

Bloom, Benjamin S., Stability and change in human characteristics. Wiley and Sons, New York 1964. 
Bobbett, Jacquline J., Ellet, Chad D., Equity and Excellence in America's Schools: The Case for Learning Equity and Proposed Models for Analysing State Wide Education Reform Initiatives. Paper presented at the annual meeting of the AERA. Chicago 1997 (March 24-28).

Bowlby, John, Attachment and loss. Vol. 1: Attachment. Basic Books, New York 1969.

Bowlby, J., A secure base. Basic Books, New York 1988.

Bredekamp, Sue, Developmentally appropriate practice in early childhood programs serving children from birth through age 8. NAEYC, Washington D. C. 1987.

Bredekamp, S., Copple, Carol, Developmentally appropriate practice in early childhood programs. Rev. edition. NAEYC, Washington D. C. 1997.

Bredekamp, S., Rosegrant, Teresa, Reaching potentials: Appropriate curriculum and assessment for young children. Volume 1. NAEYC, Washington D. C. 1993.

Bruner, Jerome, Actual minds, possible worlds. Harvard University Press, Cambridge 1986.

Caine, Renate Nummela, Caine, Geoffrey, Making connections: Teaching and the human brain. ASCD, Alexandria, VA 1991.

Caine, R. N., Caine, G., Making connections. Teaching and the human brain. Innovative learning publications. Addison-Wesley Publishing Company 1994.

Caine, R. N., Caine, G., Education on the edge of possibility. Association for Supervision and Curriculum Development, Alexandria, VA 1997.

Cenčič, Majda, Sistemi kakovosti in vzgojno-izobraževalno področje. Sodobna pedagogika 51/4 (2000), 28-42.

Capra, Fritjof, The turning point. Bantam Books, New York 1982.

Champion, Robby, Tools for Change workshop. National Staff Development Council. Cost, Quality and Child Outcomes Study Team 1995. Cost, quality, and child outcomes in child care centres: Public report. University of Colorado, Denver 1993.

Charney, Ruth, Teaching children to care: Management in the responsive classroom. Northeast Foundation for Children, Greenfield, MA 1992.

Clarke Stewart, Alison K., The »effects « of infant day-care reconsidered: Risk for parents, children and researchers. Early Childhood Quaterly 3 (1988), 293-318. 
Clarke Stewart, A. K., Infant day care maligned or malignant? American Psychologist 40 (1989), 266-273.

Clarke, Linda May Fitzgerald, Irvine Christian P. Gruber, Children at home and in day care. Erlbaum, Hillsdale, NJ 1984

Cochran, Moncrieff, Gunnarsson, Lars, A follow-up study of group daycare and family based rearing patterns. Journal of Marriage and the $\mathrm{Fa}$ mily 47 (1985), 297-309.

Cost, quality and child outcomes study team, Cost, Quality and Child Outcomes in Child Care Centers: Public Report. University of Colorado, Denver 1995.

Crosby, Philip B., Quality is free: The art of making quality certain. McGrew Hill, New York 1979.

Cryer, Debby, Burchinal, Margaret, Parents as child care consumers. Early Childhood Quarterly 12 (1997), 35-58.

Csikszentmihalyi, Mihaly, The evoking self: A psychology for the third millennium. Harper Collins, New York 1993.

Cunha, Flavio, Heckman, James J., A new framework for the Analysis of Inequality. NBER Working paper 12505. National Bureau of Economic Research, Cambridge, Mass. 2006.

Danielson, Charlotte, McGreal, Thomas L., Teacher Evaluation to Enhance Professional Practice. Association for Supervision and Curriculum Development, Alexandria 2000.

Devries, Rheta,Kohlberg,Lawrence, Constructivistearlyeducation:Overview and comparation with otherprograms. NAEYC, Washington D.C. 1990.

Delors, Jacques, The treasure Within (The Delors report on education). UNESCO, Paris 1996.

Dewey, John, Democracy and education. Macmillan, New York 1916/1985.

Dewey, J., Experience and education. Macmillan, New York 1963.

Dodge, Diane Trister, Jablon, Judy, Bickart, Toni S., Constructing curriculum for primary grades. Teaching Strategies, Inc., Washington D. C. 1994.

Dombo, Amy Laura, Sazer, Nina, Galinsky, Ellen, O’Donnell, Nina S., Melchar, Sarah, Gilkeson, Sarah, Farber, Abby, Community Mobilization: Strategies to Support Young Children and Their Families. Families and Work Institute 1996. 
Doryan, Eduardo A., Gautam, Kul C., Foege, William H., The Political change: Commitment and Cooperation. V: From Early Child Development to Human Development. Investing in our child future. Ur. M. E. Eming Young. The World Bank, Washington D. C. 2002.

Drucker, Peter F., Post-capitalist society. Harper Business, New York 1993.

Duffy, Francis M., I think before I am resistant to change. The Journal of the National Staff Development Council 24/1 (2003), 30-37.

Dunn, Loraine, Proximal and Distal Features of Day Care Quality and Children Development. Early Childhood Research Quarterly 8 (1993), 167-192.

Dwyer, Carol Anne, Stufflebeam, Daniel L., Teacher evaluation. V: Handbook of Educational psychology. Ur. D. C. Berliner, R. C. Calfee. Simon and Schuster, Macmillan, New York 1996, 765-786.

Ellet, Chad D., Classroom based Assessments of Teaching and learning. V: Evaluating teaching. A guide to Current Thinking and best practice. Ur. H. J. Stronge. 1997.

Epstein, Joyce L., A question of merit: Principals and parents evaluation of teachers. Educational Researcher 14/7 (1985), 3-10.

Epstein, J. L., Perspective and previews on research and policy for school, family and community partnerships. V: Family-school links. Ur. A. Booth, J. F. Dunn. Lawrence Erlbaum Associates, Mahwah, NJ 1996.

Erikson, Erik H., Childhood and Society. New York 1963.

Essa, Eva L., Young, Rosemary, Introduction to Early Childhood Education. Thomson, Nelson, Ontario 2003.

Evans, Judith, Arguments in Support of Investment in Early Childhood. Materials for Global Leaders Group. 2008.

Evans, Judith L., Meyers, Robert G., Ilfeld, Ellen M., Early Childhood counts. A Programming Guide on Early Childhood Care for Development. World Bank Institute, Washington D. C. 2000.

Field, Tiffany M., Preschool play. Effects of teacher-child ratio and organization of classroom space. Child Study Journal 10 (1980), 191-205.

Field, T. M., Quality infant day-care and grade school behaviour and performance. Child Development 62 (1991), 863-870.

File, Nancy, Kontos, Susan, The Realtionship of Program Quality to Children's Play in Integrated Early Intervention Settings. Topics. Early Childhood Special Education 13/1 (1993), 1-18. 
Fogel, Robert W., Foreword. V: Judith L. Evans, Robert G. Meyers, Ellen Ilfeld, Robert W. Fogel, Early Childhood Counts. A Programming Guide on Early Childhood Care for Development. World Bank Institute, 2000.

Frase, Larry E., Streshly, William, Lack of accuracy, feedback, and commitment in teacher evaluation. Journal of Personnel Evaluation and Education 1 (1994), 47-57.

Fromm, Erich, Zdrava družba. DZS, Ljubljana 1970.

Fogarty, Robin, Architects of the Intellect. Educational Leadership 57/3, 76-79.

Fröhlich-Gildhoff, Klaus, Promotion of life skills, mental health and resilience in early childhood institutions - Presentation of national situation in Germany. International workshop, Frankfurt 1999 (March 19th, 20th).

Fullan, Michael, The new meaning of educational change. Teachers College Press, New York 1991.

Fullan, M., Turning systemic thinking on its head. Phi Delta Kappan 77 (1996), 420-423.

Fullan, M., Leading in a Culture of Change. NSDC Annual Conference, Boston (uvodni referat). Boston 2002.

Gaber, Slavko, Beli knjigi na pot. V: Bela knjiga o vzgoji in izobraževanju $v$ Republiki Sloveniji. Ministrstvo za šolstvo in šport, Ljubljana 1995.

Gandini, Lella, The Reggio Emilia story: History and organization. V: First steps towards teaching the Reggio way. Ur. J. Hendrick. Merrill Prentice Hall, Upper Saddle River, NJ 1997, 1-13.

Gardner, Howard E., Frames of mind: The theory of multiple intelligence. Basic Books, New York 1983.

Gardner, H. E., Developing the spectrum of human intelligence. Harvard Educational Review 57/2 (1987), 187-193.

Gardner, H.E., The unschooled mind. Basic Books, New York 1991.

Glasser, William, The quality school: Managing students without Coercion. Harper Collins, New York 1990.

Glickman, Carl D., Supervision in Transition. Association for Supervision and Curriculum Development, 1992.

Goleman, Daniel, Emotional intelligence. Bantam, New York 1995. 
Gray, Ellen B., Child Care and family functioning: A review. Journal of Child Care 1 (1983), 15-16.

Harms, Thelma, Clifford, Richard M., Early Childhood Environment Rating Scale. Teachers College Press, New York 1980.

Hart, Leslie A., Human brain and human learning. Longman, White Plains, NY 1983.

Helm, Virginia, Conducting a Successful Evaluation Conference. V: Evaluating Teaching: A guide to current thinking and best practice. Ur. Stronge. Corwin Press, 1997.

Hendrick, Joanne, First steps towards teaching the Reggio way. Merrill Prentice Hall, Upper Saddle River, NJ 1997.

Hennessy, Elies, Melhuish, Edvard C., Early day care and the development of school-age children: A review. Journal of Reproductive and Infant Psychology 9 (1991), 17-136.

Hestenes, Linda L., Kontos, Susan, Bryan, Yvonne, Children's Emotional Expression in Child Care Centers Varying in Quality. Early Childhood Research 2uarterly 8, 295-307.

Hofferth, Sandra, Child Care, Maternal Employment and Public Policy. Annals of the American Academy 563 (1993), 20-38.

Holloway, Susan D., Reichart-Erickson, Marina, The relationship of Day Care Quality to Children's free Play Behaviour and Social Problem Solving Skills. Early Childhood Research Quarterly 3 (1988), 39-53.

Horvat, Ludvik, Vpliv sistematične predšlske vzgoje na otrokov intelektualni razvoj spsihometričnega in kvalitativno analitičnega aspekta. Doktorska disertacija. Filozofska fakulteta, Ljubljana 1983.

Howes, Carollee, Relations between Early Child Care and Schooling. Developmental Psychology 24 (1988), 53-57.

Howes, C., Can the Age of Entry into Child Care and the Quality of Child Care Predict Adjustment in Kindergarten? Developmental Psychology 26 (1990), 292-303.

Howes, C., Hamilton, Claire E., Child Care for Young Children. V: Handbook of research on the education of young children. Macmillan Publishing Company, New York 1993.

Howes, C., Olenick, Michael, Family and child care influences on toddler compiliance. Child development 57 (1986), 202-216. 
Howes, C., Philipps, Deborah, Whitebook, Marcy, Thresholds of quality implications for the social development of children in center based child care. Child Development 62 (1992), 449-460.

Howes, C., Rubenstein, Judith, Determinants of Toddler's experience in day care: Age of entry and quality of settings. Child Care Quarterly 14 (1985), 140-151.

Howes, C., Relations Among Child Care Quality, Teacher Behavior, Children's Play Activities, Emotional Security and Cognitive Activity in Child Care. Early Childhood Research 2uarterly 10 (1995), 381-404.

Howes, C., Smith, Ellen W., Galinsky, Ellen, The Florida Child Care 2uality Improvement Study: Interim report. Families and Work Institute, New York, NY 1995.

Hunt, Joseph McVicker, Intelligence and experience. Ronald Press, New York 1961.

Iglesias, Enrique V., Shalala, Donna E., Narrowing the Gap for Poor Children. V: From Early Child Development to Human Development. Investing in our child future. Ur. M. E. Eming Young. The World Bank, Washington D. C. 2002.

International Step by Step Association, Step by Step Program and Teacher Standards for Preschool and Primary Grades. ISSA, New York, Budapest, Amsterdam 2003.

International Step by Step Association, Competent Teaching for 21st Century. ISSA, Amsterdam, Budapest 2009. Http://www.issa.nl/docs_ pdfs/Pedagogical-Standards-final-WEB.pdf.

Isenberg, Joan Packer, Development issues affecting children. V: Major trends and issues in early childhood education: Challenges, controversies, and insights. Ur. Isenberg, Jalongo. Teachers College Press, New York 1997, 29-55.

Intervju z Michaelom Fullanom. The Journal of the National Staff Development Council 24/1 (2003), 55-58.

Intervju s S. Bredekamp. World Forum on Child Care and Education, Aukland 2002.

Izhodišca kurikularne prenove. NKS, Ljubljana 1996.

Jablon, Judy, Creating Curriculum in Early Childhood. V: Exploration with young children: A curriculum guide from the Bank Street School of Education. Ur. Mitchell, Davids. Grypon House, Mt. Rainer, MD 1992, 121-132. 
Jalongo, Mary Renck, Isenberg, Joan Packer, Exploring Your Role. A Practitioner's Introduction to Early Childhood Education. Merrill, Prentice Hall 2000.

Jensen, Eric, Teaching with the brain in mind. Association for Supervision and Curriculum Development, Alexandria, Virginia 1998.

Johnsson, U., A Rights Compared to a Needs Perspective on ECCD. UNICEF, Regional Office for South Asia, 1998.

Johnson, David W., Johnson, Roger T., Conflict resolution and peer mediation programs in elementary and secondary schools: A review of research. Review of educational Research 66/4 (1996), 459-506.

Jowett, Sandra, Sylva, Kathy, Does kind of preschool matter? Educational research 28/1 (1986), 21-31.

Katz, Lilian G., Impressions of Reggio Emilia Preschools. Young Children 45/6 (1990), 11-12.

Katz, L. G., Perspectives on the Quality of Early Childhood Programs. Referat na EECERA konferenci. Wurchester 1992.

Katz, L. G., Five perspectives on quality in early childhood programs. ERIC Clearinghouse on Elementary and Early Childhood Education (ERIC Document Reproduction Service No. ED-351-148), Urbana, IL 1993.

Katz, L. G., Cesarone, Bernard, Razmišljanja o pristopu »Reggio Emilia«. ERIC/EECE Univerziteta u Illinois, Institut za pretškolski i osnovnoškolski odgoj, Pedagoški fakultet, Sarajevo 1994.

Katz, L. G., Chard, Sylvia, Engaging Children's Minds: The Project Approach. Ablex, Norwood, NY 1995.

Katz, L. G., McClellan, Diane E., Fostering Children's Social Competence: The teacher's role. NAEYC, Washington D. C. 1997.

Kirpal, Simone, Communities can make a Difference: Five Cases across Continents. V: From Early Child Development to Human Development. Investing in our child future. Ur. M. E. Eming Young. The World Bank, Washington D. C. 2002.

Kontos, Susan J., Day care quality, family background and children's development. Society for Research in Child Development. Baltimore, MD 1987.

Kontos, S. J., Child Care Quality, Family Background, and Children's Development. Early Childhood Research Quaterly 6 (1991), 249-262. 
Kontos, S. J., Fiene, Richard, Child care quality, compliance with regulation and children's development: The Pennsylvania study. V: Quality in child care: What does research tell us? Ur. Phillips. NAEYC, Washington D. C. 1993.

Konvencija o otrokovih pravicah (1989). Http://www.varuh-rs.si/index. php?id=105 (30.6. 2009).

Krein, T. J., Performance reviews that rate an $\gg$ A «. Personnel 67/5 (1990), 38-41.

Krek, Janez, Bela knjiga o vzgoji in izobraževanju v republiki Sloveniji. Ministrstvo za šolstvo in šport, Ljubljana 1995.

Kroflič, Robi, Temeljne predpostavke, načela in cilji kurikula za vrtce. V: L. Marjanovič Umek, Otrok v vrtcu. Priročnik h kurikulumu za vrtce. Založba Obzorja, Ljubljana 2001.

Kurikulum za vrtce. Ministrstvo za šolstvo in šport, Ljubljana 1999.

Lally, Ronald J., Mangione, Peter L., Honig, Alice S., The Syracuse University family development research program: Long-term impact of an early intervention with low-income children and their families. V: $\mathrm{Pa}$ rent education as early childhood intervention: Emerging directions. Ur. D. R. Powell. 1988.

Lamb, Michael E., Hvang, Carl-Philip, Broberg, Anders, The Effects of Out-of-Home Care on the Development of Social Competence in Sweden: A longitudinal Study. Early Childhood Research Quarterly 3 (1988), 379-402.

Lazar, Irving, Darlington, Richard, The lasting effects of early education: A report from the Consortium for Longitudinal Studies. Journal of the Society for Research in Child Development 47 (1982), 203-223.

Laevers, Ferre, Heylen, Ludo, Involvement of Children and Teacher Style. Insights from an International study of Experiential Education. Leuven University Press, Leuven 2004.

Laevers, Ferre, Kind, Gezin, Well-being and Involvement in Care Settings, 2005. A Process-oriented Self-evaluation Instrument. Leuven University, Research Centre for ExperientialEducation.Http://www.kuleuven.be/ research/researchdatabase/researchteam/50000387.htm (30.6. 2009).

Lee, Valerie, Brooks-Gunn, Jeanne, Schnur, Elizabeth, Does Head Start Work? A one year follow-up comparison of disadvantaged children attending Head Start, no Preschool and other Preschool Programs. Developmental Psychology 24/2 (1988), 210-222. 
Love, John M., Ryer, Paul, Faddis, Bonnie, Caring Environments - Program Quality in California's Public Funded Child Development Programs: Report on the Legasletively Mandaten 1990-91. Staff/Child Ratio Study. RMC Research Corporation, Portsmouth, N. H. 1992.

Kako pomembna so pojmovanja znanja, učenja in poučevanja za uspeh kurikularne prenove (drugi del). Sodobna pedagogika 49/4 (1998), 360-370.

Profesionalizacija izobraževanja učiteljev - nujna predpostavka uspešne prenove. Vzgoja in izobraževanje 31/4 (2000), 4-11.

Barica Marentič Požarnik, Vzgoja v javni šoli: Ali je vsako širjenje vrednostnih vsebin in vzgojnih metod indoktrinacija? Sodobna pedagogika 51/1 (2000), 8-27.

Maslow, Abraham H., Motivation and personality. Harper and Row, New York 1954, 1970.

Maslow, A. H., Toward a psychology of Being. Van Nostrand Reinhold, Princeton, NJ. 1968.

Maslow, A. H., The farther reaches of human nature. Viking, New York 1973.

McCain, Margaret Norrie, Mustard, James Fraser, Shanker, Stuart, Early years study 2. Putting Science into Action. Council for Early Child Development, Toronto, Ontario 2007.

McCartney, Kathleen, Effects of Quality of Day-care Environment on children's language development. Developmental Psychology 20 (1984), 244-260.

McCartney, K., Day Care as Intervention: Comparations of Varying Quality Programs. Journal of Applied Developemental Psychology 6 (1985), 247-260.

McCartney, K., Philips, D., Motherhood and child care. V: Different faces of motherhood. Ur. Birns, Hay. Plenum, New York 1988.

McCombs, Barbara L., Whisler, Jo Sue, The learner-centered classroom and school: Strategies for increasing student motivation and achievement. Jossey-Bass, San Francisco 1997.

McGarth, Mary Jo, Dealing Positively With the Nonproductive Teacher. V: Evaluating teaching: A guide to current thinking and best practice. Corwin Press, 1997. 
Mcguire, Jacqueline, Richman, Naomi, The prevalence of behaviour problems in three types of preschool group. Journal of Child Psychology and Psychiatry 27 (1986), 455-472.

McGurk, Harry, Caplan, Marlene, Hennessy, Eilis, Moss, Peter, Controversy, Theory and Social Context in Contemporary Day Care Research. Child Psychology Psychiatry 34/1 (1993), 3-23.

Mckey, Ruth Hubbell, Condelli, Larry, Ganson, Harriet, Barrett, Bruce, McConkey, William, Plantz, Margaret C., The Impact of Head Start on Children, Families and Communities. Final Report of the Head Start Evaluation, Synthesis and Utilisation Project. The Head Start Bureau, Administration for Children, Youth and Families, Office of Human Development Services, U.S. Department of Health and Human Services. CSR Incorporated, Washington D. C. 1985.

Mčedlidze, Nina Bagratovna, Lebedenko, Aleksandra Andrejevna, Grebenščikova, Jelizaveta Anatoljevna, Istorija doškolnij zarubežnoj pedagogiki. Hrestomatija. Prosvješčenije, Moskva 1984.

Medveš, Zdenko, Pedagoška etika in koncept vzgoje (1. del). Sodobna pedagogika 42/3-4 (1991), 101-107.

Medveš, Z., Kakovost v šoli. Sodobna pedagogika 51/4 (2000), 8-28.

Melhuish, Edvard C., Lloyd, Eva, Martin, Susan, Mooney, Ann, Type of Child Care at 18 Months - II. Relations with Cognitive and Language Development. Journal of Child Psychology and Psychiatry 31/6 (1990), 861-870.

Mooney, Carol Garhart, Theories of Childhood. Redleaf Press, St. Paul, Minnesota 2000.

Montie, Jeanne E., Xiang, Zongping, Schweinhart, Lawrence, Preschool Experiences in 10 Countries: Cognitive and Language Performance at Age 7. Early Childhood Research Quarterly 21 (2006), 313-331.

Montessory school accreditation commission, Accreditation guidelines Canada. 2000.

Mustard, James Fraser, Early Child Development and the Brain - The Base for Health, Learning, and behavior throughout life. V: From early child development to Human Development. Ur. M. E. Young. The World Bank, Washington D. C. 2002.

Mustard, J. F., Bringing Child Development to Center Stage. CCF Conference 2009 (November 17). 
Mustard, J. F., Experience-based Brain Development: Scientific Underpinnings of the Importance of Early Child Development in a Global World. V: Early Child development From Measurment to Action. A Priority for Growth and Equity. Ur. E. M. Young. The World Bank, Washington 2007, 35-64.

Myers, Robert G., Role of the Private Sector in Early Child development. V: From Early Child Development to Human Development. Investing in our child future. Ur. M. E. Eming Young. The World Bank, Washington D. C. 2002.

National association for the education of young children, Guide to Accreditation by the National Academy of Early Childhood Programs. 1991.

National association for the education of young children, Accreditation Criteria and procedures. Washington D. C. 1998.

New, Rebecca , Excellent early education: A city in Italy has it. Young Children 45/6 (1990), 4-10.

OECD, Starting Strong II: Early childhood education and care. OECD, Paris 2006.

OECD, Trends Shaping Education. Centre for Educational Research and Inovation 2008.

Osborn, Albert F., Milbank, Janet E., The effects of early education: A report from the Child Health and Education Study. Oxford University Press, Oxford 1987.

Pascal, Christine, Under fives in infant classrooms. Frentham Press, Stoke on Trent, London 1990.

Perkins, David, The many faces of Constructivism. Educational Leadership 57/3 (1999), 6-11.

Peterson, C., Peterson, R., Parent-Child Interaction and Day Care: Does Quality of Day Care Matter? Journal of Applied Developmental Psycho$\log 7$ (1986), 1-15.

Phillips, Deborah A., Quality in child care: What does research tell us? NAEYC, Washington D. C. 1987

Phillips, D. A., Quality in child care: What does a research tell us? NAEYC, Washington D. C. 1993.

Phillips, D. A., Mccartney, K., Scarr, S., Child care quality and children's social development. Developmental Psychology 23 (1987), 537-543. 
Phillips, D., Mccartney, K., Scarr, S. in drugi, Bermuda Study. Report. 1993.

Piaget, Jean, Six Psychological Studies. Vintage Books, New York 1968.

Piaget, J., Inhelder, Barbel, The psychology of the child. Basic Books, New York 1969.

Policy and practice. V: Changing Kindergartens. Ur. Goffin, Stegelin. NAEYC, Washington D. C.

Pranckuniene, Egle, Vildžiuniene, Marina, Walsh, Kate Burke, Step by Step to School Improvement. Workshop materials. ISSA 2002.

Resnick, Lauren B., From aptitude to effort: A new foundation for our schools. Deadalus 124/4 (1995), 55-62.

Rogers, Carl, Freedom to Learn: A View of What Education Might Become. 4th edition. Charles Merill, Columbus, Ohio 1974.

Rogers Fortson, Laura, Reiff, Judith, Early Childhood Curriculum, Open Structures for Integrative Learning. Allyn and Bacon 1995, 9-39.

Rubenstein, Judith, The effects of maternal employment on young children. Applied Developmental Psychology 2 (1985), 99-120.

Russell, Peter, Knjiga o možganih. DZS, Ljubljana 1993.

Rutter, Michael, Family and school influence on behavioural development. Journal of Child Psychology 26 (1985), 349-368, 683-704.

Sander, Theodor, Trendi in problemi izobraževalne politike Evropske unije. Sodobna pedagogika 52/4 (2001), 10-27.

Scarr, Sandra, Developmental theories for the 1990's: Development and individual differences. Child Development 63/1 (1992), 1-19.

Schon, Donald A., The reflective practitioner - how professionals think in action. Basic Books, New York 1983.

Schlechty, Phillip C., Inventing Better Schools. Jossey-Bass, San Francisco 2001.

Schliecker, Evelyn, White, Donna R., Jacob, Ellen, The Role of Day Care Quality in the Prediction of Children's Vocabulary. Canadian Journal of Behavioral Science 23/1 (1991), 12-24.

Schweinhart, Lawrence J., Weikart, D. P., Evidence that Good Early Childhood Programmes Work. Phi Delta Kappan 66 (1985), 545-551. 
Schweinhart, L. J., Weikart, D. P., Larner, Mary B., Consequences of three preschool curriculum models through age 15. Early Education Research Quarterly (april 1986).

Schweinhart, L. J., Weikart, D. P., A summary of significant benefits: The High Scope Perry Preschool study through age 27, High Scope 1993.

Scott-Mcdonald, Kerida, Elements of Quality in Home Visiting Programs: Three Jamaican Models. V: From Early Child Development to Human Development. Investing in our child future. Ur. M. E. Eming Young. The World Bank, Washington D. C. 2002.

Scriven, Michael, The methodology of evaluation. V: Evaluating action programs: Readings in Social action and education. Ur. C. H. Weiss. Allyn and Bacon, Boston 1972.

Seefeldt, Carol, Barbour, Nita H., Developmental continuity across preschool and primary grades: Implications for teachers. ACEI Publications, Wheaton, MD 1993.

Seefeldt, C., Barbour, N. H., Early Childhood Education. An Introduction. Third Edition. Macmillan College Publishing Company, Merill, Maxwell Macmillan Canada, Maxwell Macmillan International, 1994.

Seifert, Kelvin, Cognitive development in early childhood education. V: Handbook on research on the education of young children. Ur. Spodek. MacMillan, New York 1993, 9-23.

Seitz, Victoria, Rosenbaum, Laurie H., Apfel, Nancy H., Effects of family support intervention: A ten-year follow up. Child Development 56 (1985), 376-391.

Shore, Rima, Rethinking the Brain. New Insights into Early Development. Family and Work Institute, 1997.

Siraj-Blatchford, John, Sylva, Kathy, Muttock, Stella, Gilden, Rose, Bell, Danny, Researching Effective Pedagogy in the Early Years: Research Report RR356. Department for Education and Skills, 2002.

Siraj-Blatchford, J., Sylva, K., Researching pedagogy in English preschools. British Educational Journal 30/5 (2004).

Skilbeck, Malcolm, The utility of early childhood education: An OECD view. Referat: European Conference on quality of early childhood education. Worcester 1992. 
Smith, George, James, Terry, The effect of preschool education. V: Hereditary and environment. Ur. A. H. Halsey. Methuen, London 1977.

Smith, Marshall, Bissell, Joan S., The impact of Head Start: The Westinghouse - Ohio Head Start evaluation. Harvard Educational Review 40 (1970), 51-104.

Somerick, Nancy M., Strategies for improving employee relations by using performance appraisals more effectively. Public Relations Quarterly 38/3 (1993), 37-39.

Sparks, Dennis, Change agent. The Journal of the National Staff Development Council 24/1 (2003), 55-58.

Spitz, René A., Hospitalism; An inquiry into the genesis of psychiatric conditions in early childhood. Psychoanalytic Study of the Child 1 (1945), 53-74.

Spodek, Bernard, Handbook of research on the Education of Young Children. Macmillan, New York 1993.

Spodek, B., Clark Brown, Patricia, Curriculum Alternatives in Early Childhood Education: A Historical Perspective. V: Handbook of research on the Education of Young Children. Ur. B. Spodek. Macmillan, New York 1993.

Sprenger, Marilee, Learning and Memory-The brain in action. Association for Supervision and Curriculum Development, Alexandria, Virginia 1999.

Stronge, James H., Preface. V: Evaluating Teaching: A guide to current thinking and best practice. Corwin Press, 1997.

Stronge, J. H., Ostrander, Laura P., Client survey in Teacher Evaluation. V: Evaluating Teaching: A guide to current thinking and best practice. Corwin Press, 1997.

Stuber, Margaret, Quality of Center Care and Preschool Cognitive Outcomes: Differences of Family Income. V: Sociological Studies of Child Development. Vol. 5. Ur. P. A. Adler, P. Adler. JAI Press, Greenwich, Conn. 1992.

Sylva, Kathy, Evaluating early education Programs. Child development and Care 58 (1990), 97-107.

Sylva, K., The effects of preschool education: Hard data and soft speculation. Referat: European Conference on quality of early childhood education. Worcester 1992. 
Sylva, K., Wiltshire, Jacqueline, The Impact of Early Learning on Children's Later Development. A review Prepared for RSA Inquiry »Start Right«. European Early Childhood Education Research Journal 1 (1993), 17-41.

Širec, Alojz, Slovenska šolska inšpekcija in kakovost dela šol. Sodobna pedagogika 51/4 (2000), 106-124.

Špoljar, Kornelija, Analiza interakcija odgajatelj-dijete u svrhu podizanja kvalitete odgojno-obrazovnog rada u dječjim vrtičima. Studije I izveśtaji. Institut za pedagogijska istraživanja. OOUR Pedagogijske znanosti, FF, Zagreb 1986.

Špoljar, K., Novi pristopi vzgojnoizobraževalnim programom v sodobnih konceptih predšolske vzgoje. Educa 3/1-2 (1993), 13-20.

Štrajn, Darko, Družbene spremembe in izobraževanje. V: Družbene spremembe in izobraževanje. Pedagoški inštitut, Ljubljana 1998.

Tarullo, Louisa B., Effective Early Childhood Programs: The U.S. head Start Experience. V: From Early Child Development to Human Development. Investing in our child future. Ur. M. E. Eming Young. The World Bank, Washington D. C. 2002.

Thomas, R. Murray, Comparing Theories of Child Development. Wadsworth Publishing Company, Belmont, CA. 1992.

Thomas, Nancy G., Berk, Laura E., Effects of school environment on the development of young children's creativity. Child Development 52 (1981), 1152-1162.

Turner, H. T., Hamner, T. J., Child development and Early Education. Infancy Trough Preschool. Allyn and Bacon, Boston, London, Toronto, Sydney, Tokyo, Singapore 1994.

UNESCO, World Declaration on Education for All (1990).

UNICEF, World's Summit for Children (1990). Http://www.unicef.org/ wsc/plan.htm (30.6. 2009).

United nations CRC/C/GC/7. 2006. General Comment No.7. UN Committee on the Rights of the Child.

Van der Gaag, Jacques, From child development to human development. V: From Early Child Development to Human Development. Investing in our child future. Ur. M. E. Eming Young. The World Bank, Washington D. C. 2002. 
Vandell, Deborah Lowe, Child Care for Low income Families: Dreams and real Life. V: Children and families in an Era of Rapid Change: Creating a Shared Agenda for Researchers, Practitioners and Policy Makers. Ur. F. Lamb-Parker, J. Hagen, R. Robinson, Cheryl Clark. Dept. of Health and Human Services, Washington D. C. 2001.

Vandell, D. L., Corasanti, Mary Ann, Variations in early child care: Do they predict subsequent social, emotional, and cognitive differences? Early childhood Research Quarterly 5 (1989), 555-572.

Vandell, D. L., Henderson, V. Key, Wilson, Kathy, A longitudinal study of children with day care experiences varying quality. Child Development 59 (1988), 1286-1292.

Vandell, D. L., Powers, Carol P., Day care quality and children's free play activities. American Journal of Orthopsychiatry 53 (1983), 493-500.

Vargas-Baron, Emily, Planning Policies for Early Childhood development: Guidelines for Action. The Life-Cycle Approach to ECD Policy Planning. Materials for Global Leaders Group, 1978.

Vigotsky, Lev S., Mind in Society. Cambridge, MA: Harvard University Press 2007.

Vigotsky, L. S., Sobranije sočinjenij. V dvuh tomah. Tom I. Moskva 1982.

Vonta, Tatjana, Kazalci kvalitete organizirane predšolske vzgoje. Doktorska disertacija. Filozofska fakulteta, Ljubljana 2003.

Walsh, Kate Burke, Creating child-centred classrooms. Children's Resources International in partnership With Open Society Institute, 1997.

Walsh, K. B., Na učenca osredotočena metodologija dela v 2., 3. in 4. razredu osnovne šole. Razvojno raziskovalni center pedagoških iniciativ Korak za korakom, Pedagoški inštitut, Ljubljana 2003.

Weissbourd, Richard, The myth of vulnerable child. Addison-Wesley, Reading, MA 1996.

Wheeler, Patricia H., Scriven, Michael, Building the Foundations: Teachers Role and responsibilities. V: Evaluating teachers. Corwin Press, 1997.

Wolfe, Barbara, Child Care Quality: Does It Matter and Dopes It Need to be Improved? Full Report. Institute for Research on Poverty, University of Wisconsin, Madison Publishing Company, New York 2001.

Woodhead, Martin, In search of the rainbow. Pathways to quality in largescale programs for young disadvantage children. Early Childhood De- 
velopment: Practice and Reflections, 10. Bernard van Leer Foundation, 1996.

Wortham, Sue C., The integrated classroom: The assessment-curriculum link in early childhood education. Merrill, Prence Hill, Upper Saddle River, NJ 1996.

Yoshikawa, Hirokazu, Ling-term Effects of Early Childhood Program on Social Outcomes and Delinquency. The future of children 5/3 (1995), 51-75.

Zakon o vrtcih (1996).

Zigler, Edward F., Muenchow, Susan, How to influence social policy affecting children and families. American Psychologist 39 (1984), 415-420.

Zigler, Edward F., Formal Schooling for four-years-old? American Psychologist 42 (1987), 254-260. 

kazalo

A

Abbott 84

Abrami 163

Adler 123

Ainskie 120

Airasian 170

Amonašvili 96, 107

Anderson 160, 161

Andersson 109, 117, 118, 119, 120, 121

Apfel 111

Apollonia 163

Aristotel 15

B

Bandura 33

Barbour 17, 35, 83

Barnett 113, 160, 161

Barrett 110

Barth 152, 167

Bečaj 101

Belsky 120, 121

Bennett 134, 136, 141

Bergant 21, 35
Berger $88,90,91$

Berk 144

Berliner 170

Berrueta-Clement 113

Bickart 144, 146

Birns 141

Bissell 110

Bloom 33

Bobbett 150

Booth 88, 92

Bowlby 31,89

Bredekamp 38, 65, 81, 85, 86, 87, 107

Bronfenbrenner 88

Brooks-Gunn 111

Brown 38, 110

Bruner 107, 134, 135

Bryan 123

Burchinal 125

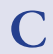

Caine 45, 46, 47, 48, 50, 84, 107, 183

Calfee 170

Caplan 109, 115, 122, 140

Capra 56 
Cesarone 92

Champion 101

Chard 108

$\mathrm{E}$

Charney 65

Ellet 150,152

Cizek 167

Epstein 88, 90, 92, 113, 163

Clark Brown 38

Erikson 35, 36, 64

Clarke-Stewart 114, 115, 118, 120,

Essa 95

121,141

Clifford 140

Cochran 118

Condelli 110

Copple 38, 65, 81, 86

Corasaniti 119, 122

Crosby 103

Cryer 125

Csikszentmihalyi 46

Cunha 181

D

Evans 60,73

F

Faddis 116,123

Farber 88

Field 115, 116, 117, 123

Fiene 117, 141

File 115

Fink 138

Fitzgerald 141

Foege 126, 128, 130

Fogarty 73

Fogel 46

Danielson 148, 152, 154, 158, 169,

Franklin 163 $170,172,173,174$

Darlington 112

Darwin 23

Frase 159

Freud 35

Fröbel 21, 22, 25, 26, 28, 29

Davids 144

Deaton 130

Fröhlich-Gildhoff 177

Fromm 35

Decroly 29

Fullan 101, 102, 138, 143, 152, 153

Delors 142

Devries 107

G

Dewey 24, 25, 26, 86, 94, 95, 107, 186, 187

Diamond 73

Dodge 144, 146

Dombo 88

Doryan 126, 128, 130

Drucker 45

Duffy 148

Dunn 88, 92, 115, 116, 123

Dwyer 170

Gaag 128, 129, 130, 133, 134

Gaber 55

Galinsky 88, 115, 116, 123

Gandini 95

Ganson 110

Gardner 45, 76, 80, 108

Gautam 126, 128, 130

Gesell 23

Gilkeson 88

Glasser 108 
Glickman 137

Goleman 83, 85

Gray 110

Grebenščikova 17, 20, 29

Gruber 141

Gullickson 170

Gunnarsson 118

\section{$\mathrm{H}$}

Hall 23

Hamilton 116, 123, 161

Hamner 35

Harms 140

Hart 67, 107

Heckman 135, 136, 181

Helms 160

Henderson 116

Hendrick 94

Hennessy 109, 114, 115, 117, 122, 140

Hestenes 123

Hitler 31

Hofferth 126

Holloway 116

Honig 113

Horvat 110

Howes 115, 116, 122, 123, 140, 141

Hunt 32, 33, 89

Huttenlocker 69

\section{I}

Iglesias 128,130

Isenberg 17, 25, 35, 37, 64, 144

J

Jablon 144, 146

Jacob 123

Jacobs 116

Jalongo 17, 25, 35, 37, 64, 144
James 67, 117, 151, 163

Jensen 67,73

Johnson 38, 46, 110

Johnsson 51

Jowett 117

K

Katz 87, 92, 93, 96, 105, 107, 125, 138, 139, 144, 162

Kirpal 125, 130

Kohlberg 107

Komenský 15

Kontos 115, 116, 117, 123, 141

Korthagen 168

Krein 160

Kroflič 82, 100

L

Lally 113

Lamb 116

Larner 113

Lazar 112

Lebedenko 17,20, 29

Lee 111

Lloyd 122

Locke 16

Love 116, 123

Luther King 32

M

Malaguzzi 94,95

Mangione 113

Marentič Požarnik 144, 147, 167, 168, 169

Marjanovič Umek 82, 100

Martin 58, 104, 122

Maslow 34, 64, 107

McCartney 115, 116, 121, 140, 141 
McClellan 144

McCombs 83, 85

McConkey 110

McGrath 165

McGreal 148, 152, 154, 158, 169, 170, $172,173,174$

McGuire 119

McGurk 109, 115, 122, 140

McKey 110, 111

McMillan 28

Mčedlidze 17, 20, 29

Medveš 48, 99, 100, 101

Melchar 88

Melhuish 114, 117, 122

Millbank 118, 119

Mitchell 144

Montessori 27, 28, 29, 38, 39, 95

Mooney 17, 24, 26, 36, 122

Moss 109, 115, 122, 140

Muenchow 110

Mustard 67, 70, 71, 96, 175

Myers 130

$\mathrm{N}$

Nelson 70,71

New 125

\section{$\mathrm{O}$}

Oberlin 20

O'Donnell 88

Olenick 116, 140

Osborn 118, 119

Ostrander 163

Overly 48

Owen 20,22, 126
P

Pascal 117, 140

Pavlov 30

Perkins 76

Pestalozzi 28

Peterson 116

Philipps 123

Phillips 115, 116, 121, 140, 141

Piaget $36,37,77,78,79,80,89,94$, 107,186

Plantz 110

Platon 15

Powers 117, 140

Pranckuniene 53, 102, 138

R

Reichart-Erickson 116

Resnick 50

Richman 119

Rogers 34, 107

Rosegrant 85, 107

Rosenbaum 111

Rousseau 16, 17, 28, 37

Rubenstein 110, 114, 141

Russell 45, 67

Rutter 115

Ryer 116, 123

$S$

Sander 52

Sazer 88

Scarr 76, 115, 116, 121, 140, 141

Schlechty 103, 107

Schliecker 116, 123

Schnur 111

Schon 147, 168

Schweinhart 113, 117, 129, 133 
Scott-McDonald 130

Scriven 152, 165

Seefeldt 17, 35, 83

Seguin 28

Seifert 78

Seitz 111

Shalala 128,130

Shore 67, 69, 75, 89, 175

Skilbeck 45

Skinner 30, 33

Smith 110, 115, 116, 117, 123

Somerick 160

Soros 96

Sparks 143

Spitz 31

Spodek 17, 21, 38, 78, 110

Sprenger 67

Stoll 138

Streshly 159

Stronge 151, 152, 160, 163, 165, 170

Stuber 123

Stufflebeam 170

Sylva 109, 117, 211

$\check{S}$

Širec 137

Špoljar 82, 93, 141

Štrajn 53

T

Tarullo 125, 130

Theall 163

Thomas 17, 34, 77, 148

Turner 35

V

Vandell 116, 117, 119, 122, 140

Van der Gaag 128, 129, 130, 133, 134
Vargas-Barón 134, 135

Vigotsky 30, 77, 78, 79, 80, 83, 89, 94, $95,96,107,146,173,187$

Vildžiuniene 53, 102, 138

Vonta 96, 158

W

Walsh 53, 102, 138, 144, 146

Watson 30, 33

Weikart 113, 117, 129, 133

Weiss 165

Weissbourd 64

Wheeler 152

Whisler 83, 85

White 116, 123, 203

Whitebook 116, 123

Wilson 116

Wiltshire 109, 117

Winsler 144

Wolfe 125

Woodhead 58, 104, 105

Wortham 83

Y

Yoshikawa 129

Young 17, 21, 37, 86, 88, 95, 123, 125, $126,128,130,175$

$\mathrm{Z}$

Zigler 110, 112

Zimmer 93 




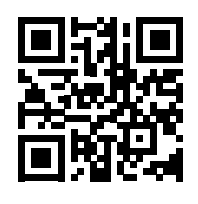

